\begin{abstract}
UNIVERSIDADE DE SÃO PAULO
ESCOLA DE COMUNICAÇÕES E ARTES

DEPARTAMENTO BIBLIOTECONOMIA E DOCUMENTAÇÃO

PROGRAMA DE PÓS-GRADUAÇÃO CIÊNCIA DA INFORMAÇÃO
\end{abstract}

PABLO MARCOS DERQUI

\title{
Da informação à categorização: a formação sistêmica dos conceitos
}


PABLO MARCOS DERQUI

\section{Da informação à categorização: a formação sistêmica dos conceitos}

Tese apresentada ao Programa de PósGraduação em Ciência da Informação do Departamento de Biblioteconomia e Documentação da Escola da Comunicações e Artes da Universidade de São Paulo, para obtenção do título de Doutor em Ciências, área: Cultura e Informação, sob a orientação da Profa. Dra. Marilda Lopes Ginez de Lara. 
Autorizo a reprodução e divulgação total ou parcial deste trabalho, por qualquer meio convencional ou eletrônico, para fins de estudo e pesquisa, desde que citada a fonte.

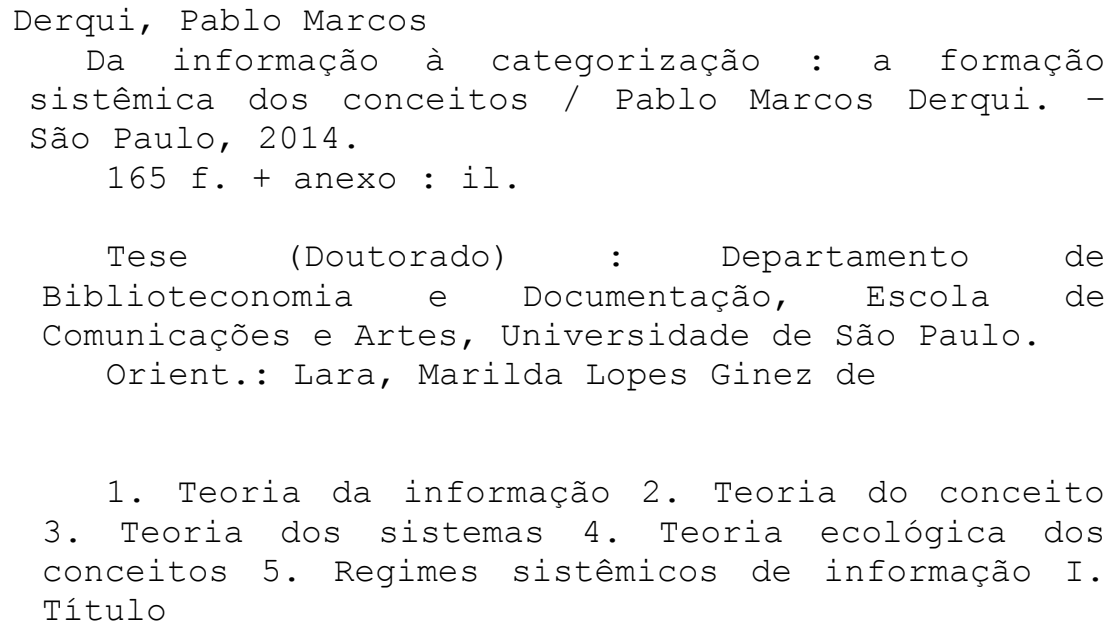


Folha de Aprovação

DERQUI, Pablo Marcos. Da informação à categorização: a formação sistêmica dos conceitos. 2014. Tese (Doutorado em Ciência da Informação) - Escola de Comunicações e Artes. Departamento de Biblioteconomia e Documentação, Universidade de São Paulo, São Paulo, 2014.

Aprovado em:

Banca Examinadora

Prof. Dr.

Instituição:

Julgamento:

Assinatura:

Prof. Dr.

Instituição:

Julgamento:

Assinatura:

Prof. Dr.

Instituição:

Julgamento:

Assinatura:

Prof. Dr.

Instituição:

Julgamento:

Assinatura:

Prof. Dr.

Instituição:

Julgamento:

Assinatura: 


\section{RESUMO}

DERQUI, Pablo Marcos. Da informação à categorização: a formação sistêmica dos conceitos. 2014. Tese (Doutorado em Ciência da Informação) - Escola de Comunicações e Artes. Departamento de Biblioteconomia e Documentação, Universidade de São Paulo, São Paulo, 2014.

As teorias sobre a formação dos conceitos em Ciência da Informação carecem de uma abordagem mais profunda sobre o principal objeto desta disciplina: a informação. Esta pesquisa realiza uma reflexão sobre essa carência tendo como estratégia considerar o problema da definição de informação e conceito como interdependentes. Essa estratégia define o problema enquanto fenômeno (como a informação interage com a formação dos conceitos?) e não a partir dos diversos exercícios de tentar definir esses conceitos. $\mathrm{O}$ objetivo da pesquisa é pautado, portanto, pela compreensão do fenômeno nos domínioschave onde a informação e os conceitos se desdobram e se complementam: o cognitivo, o social e o comunicacional. Essa compreensão requer, contudo, uma abordagem diferenciada para a questão da informação, na qual esta participe do processo de organização destes domínios, abandonando assim a perspectiva tradicional da informação como ocorrências comunicativas ou efeitos dos eventos sobre a mente. A hipótese da tese era que essa perspectiva tradicional, generalista, de informação, gera uma compreensão cognitivista da formação dos conceitos, amparada em um paradigma dualista da cognição sob a dicotomia objetivo/subjetivo. O objetivo da pesquisa foi, então, contrapor outro paradigma (não dualista) de informação, através da abordagem sistêmica, embasada nos autores Humberto Maturana, Francisco Varela, e para o fenômeno da informação Niklas Luhmann. Deste último autor, retiramos a concepção central da informação como diferenças que produzem mudanças sistêmicas, organizando-se como sistemas psíquicos ou sociais. Essa noção central foi aprofundada, a partir da ideia que a informação se organiza como regimes de aceitação de diferenças em cada um desses sistemas. Para os sistemas psíquicos, baseamo-nos em Giulio Tononi, para quem o emaranhamento entre complexos de informação integrada (criando regimes expansivos) permite a emergência de conceitos. À medida que esse regime permite a emergência de sistemas de consciência que regulam o foco sobre esses conceitos, sugerimos - baseados na abordagem ecológica dos conceitos de Liane Gabora, Eleonor Rosch e Diederik Aerts - que ele, então, passa a ser complementado por outro, redutivo, que abstrai e desvincula os conceitos de seus contextos imediatos, permitindo a imaginação. Esse corpo teórico foi então confrontado com os dilemas teóricos levantados na literatura do Corpus - composto por artigos que tratassem dos processos de categorização ou aspectos cognitivos da teoria dos conceitos em Ciência da Informação. Constatamos que, em CI, a questão da formação dos conceitos confirmava a hipótese: a área de organização do conhecimento opta por uma visão cognitivista e dualista em que os conceitos se formam a partir de um núcleo de representações invariáveis (de natureza perceptiva) e os aspectos contextuais ficam restritos a operações periféricas de identificação. Concluímos que o paradigma representacionista é, em geral, dominante e que a área de organização da informação e conhecimento (e também a CI) deveria se abrir para outras abordagens, e propusemos como uma alternativa a abordagem sistêmica da informação, que apresentamos nesta pesquisa.

Palavras-chave: Teoria da informação. Teoria do conceito. Teoria dos sistemas. Teoria ecológica dos conceitos. Regimes sistêmicos da informação. 


\begin{abstract}
DERQUI, Pablo Marcos. From information to categorization: the systemic formation of concepts. 2014. Thesis (Library and Information Science) - Escola de Comunicações e Artes. Departamento de Biblioteconomia e Documentação, Universidade de São Paulo, São Paulo, 2014.
\end{abstract}

The theories about the formation of concepts in Information Science (IS) lack of a deeper approach on this discipline's main object: information. This research carries out a reflection on this lack adopting the strategy of considering the issues of information definition and concept as interdependent. This strategy defines this issue while phenomenon (how information interacts with the formation of concepts?), avoiding the departure from several exercises to try to define these concepts. Therefore, this research's objective is guided by the comprehension of that phenomenon in the keydominions where information and concepts unfold and complete each other: the cognitive, the social and the communicational ones. However, this comprehension requires a differentiated approach for the issue of information, in which it participates of this dominions organization process, thus leaving the traditional perspective of information as communicative occurrences or event effects on mind. This thesis' hypothesis was that this traditional and generalist perspective of information generates a cognitivist comprehension of formation of concepts, supported by a dualist paradigm of cognition under the dichotomy objective/subjective. This research's objective was to offer another (non-dualist) paradigm of information through the systemic approach based on the authors Humberto Maturana, Francisco Varela and, for the information phenomenon, Niklas Luhmann. From this last author, we took the core conception of information as differences that produce systemic changes, auto-organizing themselves as psychic or social systems. This core notion was deepened with the idea that information organizes itself as regimes of differences acceptation in each of these systems. For the psychic systems, we used Giulio Tononi, for whom the tangling between complexes of integrated information (creating expansive regimes) allows the emergence of concepts. As this regime allows the emergence of conscience systems that rule the focus on these concepts, we suggest - based on the ecological approach of Liane Gabora, Eleonor Rosch and Diederik Aerts - that it is, now, complemented by other, reductive, that abstracts and detaches the the concepts from its immediate concepts, acknowledging imagination. This theoretical body was, then, confronted with the theoretical dilemma in the gather of Corpus literature - composed by articles that tackled the processes of categorization or cognitive aspects of concepts theory in Information Theory. We verified that, in IS, the issue of formation of concepts confirmed the cognitivist hypothesis: the area of knowledge organization chose the cognitivist and dualist vision in which concepts are formed by a nucleus of invariable representations (of perceptive nature) and the contextual aspects are restricted to peripheral identification. We concluded that the representational paradigm is, in general, hegemonic and that the areas of information and knowledge organization (and also IS) should open to other approaches, proposing the systemic approach of information as an alternative, which is presented in this research.

Keywords: Information theory. Concept theory. Systems Theory. Ecological theory of concepts. Systemic information regimes. 


\section{DEDICATÓRIA}

Em memória da minha amada mãe, falecida durante o percurso desta pesquisa. 


\section{AGRADECIMENTOS}

Agradeço à Profa. Dra. Marilda Lopes Ginez de Lara, pela oportunidade de realizar esta pesquisa e por sua inestimável orientação.

Agradeço especialmente às professoras doutoras da banca de qualificação, Irene de Araújo Machado e Lúcia Maciel Barbosa de Oliveira, pelas observações e orientações que muito me ajudaram na construção desta tese.

E agradeço eternamente à minha companheira Maria Aparecida Laet, porque sem seu apoio e compreensão dos meus momentos difíceis teria sido impossível continuar esta pesquisa. 


\section{SUMÁRIO}

$\begin{array}{ll}\text { INTRODUÇÃO } & 8\end{array}$

Capítulo 1 - Informação e Teoria do Conceito em Ciência da Informação 12

Capítulo 2 - A Abordagem Sistêmica da Informação 32

2.1 O Conceito de Sistema 36

Capítulo 3 - Sistemas de Sentido: a regência da informação 58

3.1 Informação, Comunicação e Organização 69

3.2 A Regência da Informação nos Sistemas Psíquicos e Sociais 76

3.2.1 Sistemas psíquicos e sociais na geração da seleção de sentido 92

Capítulo 4 - A Formação Sistêmica dos Conceitos $\quad 125$

$\begin{array}{ll}\text { CONCLUSÕES } & 151\end{array}$

$\begin{array}{ll}\text { BIBLIOGRAFIA } & 159\end{array}$

ANEXO: Corpus bibliográfico 


\section{INTRODUÇÃO}

Esta pesquisa busca aclarar o próprio conceito de conceito, mas através da compreensão, negligenciada, da passagem da informação à formação do conceito. Essa passagem é a fonte de nosso problema imediato: como abordar a informação para que se possa entender qual é o seu papel na complexa questão da formação dos conceitos. Uma compilação dos conceitos de informação apenas ofereceria um contraste entre noções diferentes, não uma ferramenta de análise. Pela mesma razão, uma compilação sobre as noções de conceito revelaria uma lista muito numerosa de concepções sem que dela se pudesse retirar, necessariamente, uma explicação sobre a formação dos conceitos a partir da informação. Por outro lado, uma abordagem que focasse ambos os conceitos como fenômenos compartilhando a mesma problemática poderiam revelar os processos em comum que precisariam ser deslindados.

O que conceitos e informação possuem em comum é a extrema dificuldade de definição em razão da contextualidade a que estão sujeitos os dois termos. Definimos essa contextualidade, então, como reveladora do obstáculo epistemológico a ser enfrentado: o tratamento uniforme dado a estes conceitos enquanto fenômenos. Com isto queremos dizer que, na abordagem teórica da informação e da definição do conceito de conceito em Ciência da Informação, procura-se defini-los através de uma explicação que não leva em consideração uma mudança na natureza do fenômeno ao mudar de contexto. Por exemplo, se informação é "algo que afeta a mente" e conceito "uma unidade de conhecimento" (algo comunicado) o que acontece com aquela informação que estava na mente ao ser comunicada? Questão que nos leva para outra mais geral: os conceitos de informação e conceito, em Ciência da Informação, estão relacionados entre si quanto às esferas da experiência de que participam (cognitiva, social/cultural)?

A nossa hipótese de trabalho é que não estão, estando presos, na verdade, a uma explicação da formação dos conceitos desde um dualismo objetivo-subjetivo, em que a informação aparece divorciada desse processo como uma mera ocorrência atrelada a um processo de conhecimento objetivo (fundamentado no mundo) ou subjetivo (fundamentado no sujeito). Acreditamos que esse paradigma dualista seria derivado de uma visão conservadora da cognição, centrada na ideia da representação como um procedimento de arquivamento mental, que pouco contempla a representação enquanto uma mediação entre as esferas cognitiva, social e cultural da experiência 
humana ${ }^{1}$. A abordagem que iremos propor irá na direção de inverter essa postura, privilegiando a mediação como formadora da cognição. Como observam Kobashi e Francelin (2011), existe a necessidade de aprofundar e confrontar os paradigmas dos cânones tradicionais do tratamento e organização do conhecimento, nomeadamente, na teoria do conceito, através de novas abordagens que levem em consideração as questões cognitivas, sociais e culturais. Uma vez que estas esferas da experiência humana precisam ser trazidas para o centro do debate cognitivo, isso só será possível a partir de uma noção de informação que se articule com estas esferas, que não fique restrita fenomenologicamente - à esfera do mental e do cognitivo. Tal noção de informação tem que estar na mesma costura da explicação da formação dos conceitos, tem que ser capaz de se mostrar - junto com os conceitos - como participante na constituição destas esferas da experiência, e não apenas um veículo de sua apreensão pela mente. Por estas razões, a abordagem que propomos se baseará em aclarar, primeiramente, o conceito de informação a partir de uma compreensão sistêmica do mesmo.

Desde os anos 1950, verifica-se um ápice no emprego do conceito de informação, sem, contudo, denotar algum esforço em atingir clareza conceitual. Fala-se em informação genética e tratam-se as estruturas como conteúdos de informação, por exemplo, na terminologia dos códigos genéticos. No entanto, a questão que deve guiar as reflexões sobre o conceito de informação reside em saber qual é a escala na qual a informação é capaz de selecionar. (LUHMANN, 2002, p. 139-140).

Empreender uma nova compreensão da informação, na qual esta possua uma escala de seleção em consonância com as esferas cognitiva e social/cultural, e assim aplicável à formação dos conceitos nesses domínios da experiência é o objetivo desta pesquisa. O intuito geral é colocar o fenômeno da informação como central ao debate sobre a natureza dos conceitos. Mas esse será, também, o limite do escopo de nossa abordagem. Não apresentaremos um modelo da formação dos conceitos baseados nessa visão alternativa, pela razão principal que as teorias sistêmicas nessa área ainda estão em elaboração e integrá-las demandaria praticamente uma pesquisa à parte. Também por estas limitações, o objetivo secundário desta pesquisa se restringirá a uma reavaliação paradigmática da literatura em Ciência da Informação sobre o tema da

\footnotetext{
1 Salientamos que a representação enquanto mediação é pouco explorada quando explicada como processo cognitivo, especialmente na área de organização e tratamento da informação. Fica excluído desta pesquisa o modo como a noção de representação é tratada em outras áreas da Ciência da Informação, como as áreas de Ação Cultural ou Estudos da Mediação.
} 
formação dos conceitos. O levantamento dessa literatura constitui o Corpus de análise de nossa pesquisa por revelar as concepções sobre a formação dos conceitos, objetivadas nos estudos sobre o processo de categorização.

A metodologia a ser usada, baseada na natureza hipotético-dedutiva da pesquisa, partirá da hipótese já mencionada acima, e o quadro teórico de referência trabalhará os conceitos centrais da abordagem sistêmica em contraponto à abordagem cognitivista. Este ponto inicial é essencial para a análise da literatura encontrada no levantamento bibliográfico do Corpus. A abordagem sistêmica será centrada nos autores que revisitaram os conceitos da Teoria dos Sistemas e da Teoria da Informação a partir das preocupações com o problema da complexidade, dos sistemas auto-organizados e do papel do observador na teoria cognitiva. Os autores de base para essa abordagem são Humberto Maturana Romesín e Francisco Varela García. Para a perspectiva do papel sistêmico da informação, o sociólogo alemão Niklas Luhmann apresenta uma teoria dos sistemas sociais que será chave por considerar que a comunicação se orienta pela diferença. Para recolocar o papel da informação em termos cognitivos, porém sistêmicos, será abordada a Teoria da Informação Integrada, de Giulio Tononi. A perspectiva sistêmica adotada neste trabalho também levará em conta as questões evolucionistas que o problema da categorização como fenômeno cognitivo suscitam. Dentro dessa complementação, a teoria ecológica da formação dos conceitos, desenvolvida por Liane Gabora, Eleonor Rosch e Diederik Aerts contribui fundamentalmente.

Os critérios para o levantamento bibliográfico pretendem ser adequados para a análise do objeto de estudo segundo a proposta dos objetivos e em acordo com a hipótese, portanto:

A. A estratégia de busca focalizará a literatura que abordar os assuntos categoria(s) e categorização enquanto preocupação teórica, ou seja, como conceitos explicitamente colocados. Esses termos foram escolhidos porque a formação dos conceitos concentra-se, enquanto estudo cognitivo, na formação das categorias por serem estas mais simples em sua composição. Esses assuntos enquanto conceitos implicitamente trabalhados não serão recuperados, senão secundariamente;

B. Em razão de levantamentos preliminares que constataram uma exiguidade dessa literatura não será imposta uma limitação cronológica; 
C. Serão excluídos trabalhos nos quais os assuntos categorias e categorização forem abordados de outros pontos de vista que não o cognitivo ou da teoria do conceito, como por exemplo, na recuperação automática de textos (Text categorization).

Os resultados do levantamento preliminar podem ser encontrados no anexo.

No planejamento desta pesquisa, a análise do Corpus será precedida pela explanação dos fundamentos teóricos que sustentam a nossa abordagem, baseada esta na análise sistêmica do problema da formação dos conceitos. Esses fundamentos serão longamente desenvolvidos nos capítulos 1,2 e 3 . No primeiro capítulo, será abordado como a informação aparece, enquanto preocupação epistemológica, na teoria do conceito em Ciência da Informação. No segundo capítulo, serão abordados tanto o conceito de sistema quanto o de informação, mas contextualizando este último como fenômeno a ser compreendido a partir da fenomenologia da formação dos sistemas. No terceiro capítulo, já a partir de uma compreensão sistêmica do fenômeno da informação, serão abordados os sistemas de sentido como geradores dos contextos cognitivos e sociais nos quais ocorre a formação dos conceitos. Finalmente, no quarto capítulo será abordado o próprio Corpus da pesquisa, revelando as questões e os impasses teóricos da área da organização do conhecimento e da informação em relação à formação dos conceitos em sua dimensão cognitiva e comunicacional. Do cotejamento entre esses impasses e a nossa abordagem teórica (a perspectiva sistêmica da informação) será proposta para estes primeiros uma compreensão alternativa àquelas colocadas geralmente na área da organização do conhecimento e da informação. Esta compreensão estará calcada no confronto do paradigma representacionista (baseado no dualismo objetivo-subjetivo) com a abordagem sistêmica baseada no observador como criador da realidade e das representações (cibernética de segunda ordem). O objetivo final é subverter a ordem na qual os conceitos são derivações da cognição para recolocar a dimensão do sentido (como uma articulação do psíquico, da linguagem e da cultura) como geradora da cognição. 


\section{Capítulo 1}

\section{Informação e Teoria do Conceito em Ciência da Informação}

Abriremos nossa discussão com um problema que consideramos fundamental: a relação entre informação e conceito. Não tentaremos, ainda, definir cada um destes conceitos, mas, isto sim, mostrar como estes são apresentados e trabalhados em Ciência da Informação. O obstáculo principal nesta apresentação (e que se afigura para nós como um verdadeiro obstáculo epistemológico) é que um conceito de conceito que não incorpora explicitamente um conceito de informação enquanto fenômeno trabalhará com uma noção implícita de informação que determinará como podemos definir (ou seja, nos informar sobre) qualquer coisa ou evento no mundo, o que inclui, paradoxalmente, uma definição de informação. Esta é a situação que encontramos nos trabalhos de Ciência da Informação sobre a teoria do conceito: noções não explicitamente incorporadas de informação que, por sua vez, impedem que a teoria do conceito formule adequadamente como se define um conceito. Isto é, que se faça apropriadamente a pergunta: como nos informamos sobre algo a ponto de dizermos que constituímos um conceito a respeito desse algo?

Não queremos dizer aqui que a teoria do conceito não possui instrumentos teóricos para sistematizar definições conceituais (em Dahlberg - 1978a, 1978b, 1978c, 1979 -, isso é categoricamente abordado), mas que a teoria considera como tácito o que seria informação, seja como "conhecimento comunicado" ou "algo que afeta a mente". O que defendemos é que em Ciência da Informação a relação entre informação e formação dos conceitos (ou construção categorial) é fracamente delineada. O que nos obriga a mostrar não essa relação conceitual, mas as noções implícitas de informação que conformam as escolhas teóricas para a explicação da formação dos conceitos. Apenas após colocarmos claramente essas escolhas é que poderemos prosseguir numa análise da relação entre informação e conceito que, por contraste ao problema das noções implícitas de informação na teoria do conceito, formulará uma abordagem explícita do fenômeno da informação e, portanto, epistemologicamente distinta. 
Não se tratará aqui de uma análise da teoria do conceito como um todo, mas de um olhar crítico sobre suas escolhas epistemológicas. Defendemos que estas escolhas se conformam de acordo com o modo como é entendido o processo cognitivo humano, o qual, em sua conformação teórica mais abrangente e geral, gira em torno de um dilema: a cognição como representação ou como solipsismo.

A defesa do solipsismo possui uma história na Filosofia, mas dentro das ciências cognitivas passou a ser considerado apenas pela sua asserção negativa sobre a experiência material do pensamento (a mente não mantém contato com uma realidade material, tudo que é pensado tem origem puramente mental). Como o solipsismo leva seu raciocínio ao extremo de afirmar que nem mesmo se pode supor a existência de outras mentes (porque seriam também uma criação mental), não pode supor nem mesmo a comunicação, o que o torna inviável como explicação do fenômeno cognitivo. Por esta razão, as correntes investigativas e as disciplinas aplicadas ao estudo da cognição tomam o solipsismo como um erro lógico a ser evitado ${ }^{2}$. Em seu lugar, essas correntes e disciplinas utilizam a noção de representação, já de uso antigo na Filosofia. A noção de representação pleiteia um vínculo de continuidade entre a realidade externa e os conteúdos mentais. A mente usaria substitutos da realidade (representações), que, embora sendo constituídos da pura atividade mental (uma não-coisa, portanto, não real), guardam uma verossimilhança com a realidade porque são construídos a partir da percepção (e esta seria em grande parte uma transposição das formas e organização da realidade externa). Desse modo, se explicaria a cognição, principalmente, como um processo de representar algo, inclusive o que não existe (objetos e eventos imaginários), já que mesmo o que é imaginado se baseia em algo que foi percebido e depois recombinado numa forma livre. Assim, as representações serviriam para descrever tanto o que acontece na realidade quanto na mente, só sendo necessário formalizar o seu uso, o que provaria a utilidade da noção de representação para explicar satisfatoriamente o processo cognitivo.

Mas por que então afirmamos anteriormente que há um dilema entre representação e solipsismo? Porque o mencionado vínculo de continuidade entre realidade e mente é muito difícil de delinear, obrigando a noção de representação a trabalhar como uma dualidade: um vínculo mais forte com a realidade (as

\footnotetext{
${ }^{2}$ Bertrand Russel foi o lógico que mais acidamente criticou o solipsismo, como na anedota (contada por ele) da mulher que se dizia solipsista e que se espantava por não encontrar mais ninguém como ela (RUSSELL, 1948).
} 
representações que trabalham com aquilo que não é mental, isto é, objetos) e um vínculo mais fraco (as representações que se voltam para os próprios processos mentais). Ao primeiro vínculo chamaríamos de objetividade (representações voltadas para aquilo que está fora da mente) e ao segundo vínculo de subjetividade (representações voltadas para aquilo que subjaz na mente). Esse dualismo, quando passa a valorizar sobremaneira o vínculo subjetivo, torna-se uma ameaça ao próprio vínculo com uma realidade externa e independente ao enfatizar uma primazia do pensamento sobre a experiência sob o argumento que tudo que podemos conhecer o podemos somente através da representação. Ou seja, mesmo sem se abandonar a noção de representação, reintroduz-se o solipsismo:

A noção de representação resiste mesmo ao embate filosófico entre realistas e idealistas. Para os realistas, há uma distinção entre ideias ou conceitos e o que elas representam, isto é, o mundo, que é onde o julgamento de sua validade pode se dar. Aqui, postula-se que cada representação deve ser consistente com diversas outras com as quais mantém relações, o que atende à necessidade de aumentar o grau de adequação ou correspondência que elas venham a ter, em conjunto, com o mundo externo. Para os idealistas, não temos qualquer acesso ao mundo externo a não ser através de nossas representações, de modo que é impossível sabermos o que é esse mundo lá fora, e que é objeto de nossas representações, uma vez que não podemos sair de nós mesmos para aferir o grau de adequação que elas mantêm com o mundo. Mais ainda, para o idealista, o próprio mundo externo é mais uma de nossas representações. (MAGRO, 1999, p. 29).

O dilema entre representação e solipsismo, portanto, se encontra inclusive dentro da noção de representação. Desse modo, a construção do conceito de representação se esforçará por depurar a tendência ao solipsismo retirando da noção de representação qualquer apelo transcendental sobre sua ligação com um mundo externo e independente, assim reduzindo, por seu turno, o apelo a um subjetivismo derradeiro que negue às representações seu vínculo com uma realidade externa. Nessa depuração, será o próprio indivíduo o repositório das verdades apriorísticas na forma do

[...] agente cognitivo como um ser dotado de um mapa sob a forma de um sistema de representações do mundo, ou uma caixa de ferramentas de exploração cognitiva, inatamente especificados, que ele aprende a utilizar ao longo de sua ontogenia. (MAGRO, 1999, p. 30).

Essa abordagem foi a adotada pelas ciências cognitivas em sua vertente mais clássica, cujos esforços se concentraram 
[...] na proposição dos mecanismos abstratos e computacionais concebidos como responsáveis pelo funcionamento da cognição e da linguagem, especialmente os postulados como condições apriorísticas, e aqueles que fornecem fundações não contingentes para nosso conhecimento do mundo. (MAGRO, 1999, p. 30).

A essa vertente mais clássica corresponde o cognitivismo, que se baseia na ideia de que tudo que é necessário para a cognição já está pressuposto no indivíduo, faltando apenas os estímulos do ambiente, ideia essa que teria sido o principal leitmotiv a embasar o pensamento e a pesquisa sobre a mente e o conhecimento no ocidente, tendo nas ciências cognitivas ortodoxas a sua expressão teórica, pois estas, "inclusive a Linguística, abrigou como postulados inquestionáveis a ideia de que o ser humano individual dispõe de todas as condições de sobrevida no meio em que está, o qual é prévio a ele e independente dele" (MAGRO, 1999, p. 30). O cognitivismo é, assim, o fundamento para o objetivismo moderno, para o cerceamento do subjetivismo, o qual passa a ser enquadrado como representações imprecisas que precisam justificar seu valor informativo. Assim, baseando-se na noção crua da teoria da informação como uma teoria da transmissão de conteúdos, a noção de representação encontra na noção de informação um esteio para a concepção da cognição como formada pela separação entre representações objetivas e representações subjetivas, passando estas duas noções a ficar estreitamente associadas.

Essas duas noções, a de representação e a de informação, passaram a caminhar juntas delineando um modo de pensar fenômenos relativamente estáveis, ou descritíveis através de conjuntos de regras, portadoras inquebrantáveis de características necessárias para a ocorrência dos processos cognitivos e linguísticos. (Ibid., p. $31)$.

Em Ciência da Informação, essa associação entre representação e informação pode ser encontrada na recorrente formulação dados-informação-conhecimento. Para Chaim Zins (KNOWLEDGE map..., 2006), por exemplo, esse tripé é justificado através da existência de dois domínios (o objetivo e o subjetivo), os quais determinam extrinsecamente a qualidade das representações como pertencendo a um desses domínios. Em suas palavras, "há, basicamente, duas abordagens para definir 'conhecimento': o domínio subjetivo (i.e., como um pensamento na mente do sujeito) e 
o domínio objetivo (i.e., como um objeto)"33 (KNOWLEDGE map..., 2006, tradução nossa). Embora se relativize a polarização da dualidade objetivo-subjetivo, como mutuamente dependentes ("a realização do conhecimento objetivo necessita da consciência de ao menos um indivíduo conhecedor" (Ibid., tradução nossa)) ${ }^{4}$, o que se propõe é o espelhamento do mundo através da percepção, a qual modula o domínio subjetivo (que aqui é cognitivo e não mais solipsista) e que por sua vez se reflete no domínio objetivo.

Dados objetivos, informação objetiva, e conhecimento objetivo espelham suas contrapartes objetivas. Eles são representados por símbolos objetivos e podem ter formas diversas como sinais esculpidos, formas desenhadas, palavras impressas, sinais digitais, emanações de luz, ondas de som e manifestações similares. (KNOWLEDGE map..., 2006, tradução nossa).

Essa proposta se cristaliza na natureza representacional do tripé dadosinformação-conhecimento, como na seguinte proposta de Zins para a conversão dos três conceitos no domínio objetivo:

"Dados" são conjuntos de símbolos que representam percepções empíricas, "Informação" é um conjunto de símbolos que representam conhecimento empírico, "Conhecimento" é um conjunto de símbolos que representam pensamentos que o indivíduo justificadamente acredita serem verdadeiros. ${ }^{6}$ (Ibid., tradução nossa).

O tripé dados-informação-conhecimento, em seu domínio objetivo, é precedido - segundo Zins - pelo domínio subjetivo, no qual "dados" são estímulos do ambiente, "informação" um tipo de conhecimento empírico, e "conhecimento" é um pensamento específico existente na mente individual (Ibid.). Pode-se depreender dessas afirmações que, no domínio subjetivo, dados são percepções, informação um tipo de juízo perceptivo e conhecimento aquilo que se cristaliza na mente como resultado de um juízo bem-sucedido das percepções recebidas. O domínio objetivo, por seu lado, seria a

\footnotetext{
${ }^{3}$ [...] There are two basic approaches to define 'knowledge': in the subjective domain (i.e., as a thought in the subject's mind) and in the objective domain (i.e., as an object). (KNOWLEDGE map..., 2006).[Este trecho, assim como outros indicados em nota de rodapé, teve tradução livre do autor desta tese].

${ }^{4}[\ldots]$ The realization of objective knowledge necessitates the consciousness of at least one individual knower. (Ibid.).

${ }^{5}$ Objective data, objective information, and objective knowledge mirror their cognitive counterparts. They are represented by empirical symbols, and can have diversified forms such as engraved signs, painted forms, printed words, digital signals, light beams, sound waves, and the like. (Ibid.).

6 'Data' are sets of symbols that represent empirical perceptions, 'Information' is a set of symbols that represent empirical knowledge, 'Knowledge' is a set of symbols that represent thoughts that the individual justifiably believes are true. (Ibid.).
} 
transcrição do tripé subjetivo para algum meio que este (por exemplo, "símbolos") fique representado. As representações objetivas, sob esse prisma, precisariam espelhar o tripé cognitivo (subjetivo). Como nessa sequência a mente e o subjetivo estão entre o mundo e a objetividade, torna-se inevitável que a subjetividade, para se apresentar crível, necessita justificar-se constantemente em relação ao que está no mundo. Se esse é um esquema que pretende assegurar a objetividade das representações via percepções empíricas (dados $\rightarrow$ informação), por outro lado, coloca o indivíduo como um "ruído" entre o mundo e a objetividade quando este se afasta das percepções empíricas para se refugiar na sua mente. $\mathrm{O}$ esquema representacionista é, assim, inseguro quanto a suas premissas iniciais. O que garante que um dado estímulo será sempre convertido na representação correta? Ou mesmo de que a informação é precedida por dados (estímulos do ambiente)? Nos sonhos existe uma miríade de informações sem quase nenhuma intervenção dos “dados do ambiente". A ideia de uma sequencialidade, como um tripé cognitivo que põe em pé as representações, possui lacunas que não a corroboram. Como afirma Capurro, "colocar os três conceitos (dados, informação, conhecimento), como feito aqui, dá a impressão de uma hierarquia lógica: a informação é definida como derivada dos dados e o conhecimento como derivado da informação. Isso é um conto de fadas"7 (KNOWLEDGE map..., 2006, tradução nossa).

A Ciência da Informação, assim como outras ciências que estudam o fenômeno humano, incorporaram, em alguma medida, a noção de representação burilada pelo cognitivismo sem, contudo, elaborar uma explicação que fundamente seu uso. Pelo contrário, o status ontológico das representações é dado como autoexplicativo, baseando-se na presunção de que, assim como as "percepções empíricas" e o “conhecimento empírico”, a representação é autoevidente como fenômeno ${ }^{8}$. Mas o que é considerado como autoevidente geralmente não só carece de explicações como também passa a ser considerado um conhecimento tácito que não requer nenhum aprofundamento. Como observa Magro (1999), a noção de representação possui a

\footnotetext{
${ }^{7}$ Putting the three concepts (data, information, knowledge) as done here, gives the impression of a logical hierarchy: information is set together out of data and knowledge comes out from putting together information. This is a fairytale. (KNOWLEDGE map..., 2006).

${ }^{8}$ Como foi salientado na Introdução, nesta pesquisa, 'representação' aparece enquanto conceito cognitivo, como explicativo do funcionamento da mente, portanto, a visão social da representação, como mediações de sentido (e não como algo que possui existência independente, funcional), não está em questão, a não ser quando esta se justifica através do representacionismo cognitivo (mas essa questão também não será avaliada aqui). O que se procurará deixar mais claro nesta pesquisa, é o conceito cognitivista de representação para que suas características sejam reconhecidas até quando sejam invocadas no contexto da representação como mediação de sentido.
} 
mesma capacidade explicativa da Virtus Dormitiva ${ }^{9}$ de Molière, mas, ao contrário desta que desperta risos, a noção de representação transita livremente e com autoridade dentro do discurso científico, apesar de sua opacidade.

Não raro, como justificativa de seu uso, explicita-se a concepção mais leiga, ingênua e pré-teórica do termo. Costumamos ouvir que representação é aquilo que fica no lugar de outra coisa, como uma imagem visual ou sonora. No domínio dos fenômenos mentais, ouvimos com frequência: é aquilo que temos dentro de nossa cabeça e que nos permite compreender o que nos ocorre. Ou: é aquilo que formamos/temos na nossa cabeça e que nos permite reconhecer alguém, interpretar sentenças ou tomar decisões. Essa atitude é apenas aparentemente despretensiosa: por fazer parte das mais corriqueiras afirmações de nossa cultura, de uma arquitetura vocabular que afirma que palavras representam entidades de mundos reais ou fictícios, externos ou internos, e que temos tudo isso, mais um conjunto de procedimentos combinatórios, representados em nossa cabeça ou cérebro, o lócus de qualquer atividade intelectual e psíquica, tem consequências difusas na nossa maneira de conceber nosso estar no mundo. (MAGRO, 1999, p. 32, grifos nossos).

A partir do trecho acima, temos exemplos (grifados) das noções de representação que poderiam muito bem ser intercambiáveis com as de informação em Ciência da Informação, por exemplo, com a noção de informação "como algo que afeta a mente”. Essa fusão (ou confusão) conceitual, porém, não é coincidência. De fato, pleiteamos que esse paralelismo conceitual forma, na verdade, uma articulação que se baseia na presunção de que o mundo preexiste como dados para as representações, e que estas apenas reconstituem (bem ou mal, objetiva ou subjetivamente) as informações nesses dados, possuindo tanto as representações quanto a informação uma mesma natureza de "conduíte" entre o mundo e a mente.

Defendemos, ainda, que essa articulação informação/representação prospera mesmo quando o tripé "dados-informação-conhecimento" é acatado parcialmente, criticado ou abandonado. Ao contrário dos paradigmas de Capurro (2003, 2007), que, segundo ele, são inconstantes, a visão representacionista da mente, em Ciência da Informação, seria, como defenderemos aqui, uma constante argumentativa, seja sob o

\footnotetext{
9 "Numa de suas mais perspicazes peças teatrais, $O$ Doente Imaginário, Molière encena um exame oral, no qual um doutor em medicina pergunta a um bacharel qual "a causa e a razão" do ópio pôr as pessoas para dormir. Triunfante e cheio de certeza, ele responde no seu melhor latim: "Quia est ineo Virtus dormitiva" ["Porque há nele uma força dormitiva"]. É aplaudido pelo coro, e aceito como membro do corpo de doutores." (MAGRO, 1999, p. 29).
} 
"paradigma cognitivo" ou o "paradigma social"10. É, por exemplo, uma noção regularmente invocada no campo do tratamento e organização do conhecimento. A própria teoria do conceito deve a seus primeiros desenvolvimentos na Filosofia um apego de longa data à noção de representação.

De acordo com Smith e Medin (1981, p. 22), a visão clássica é uma teoria psicológica sobre como os conceitos são representados na espécie humana e em outras espécies. Na filosofia, a origem dessa visão remonta a Aristóteles; na psicologia experimental essa visão foi traçada através da pesquisa de Hull (1920) sobre estabelecimentos de conceitos. Tanto para Platão como para Aristóteles, os conceitos são definidos por suas essências. Enquanto que o estudo de Platão foca nas formas ideais, o que distanciou da teoria científica sobre conceitos, muitos estudiosos, na metade do século 20, baseavam seus estudos nas ideias de Aristóteles, tratando os conceitos como sendo definidos por um jogo de características necessárias e suficientes, que eram descobertas empiricamente, sendo uma proposta de representação e não de processo (LIMA, 2010, p. 112).

Ingretaut Dahlberg $^{11}$ (1978a), em sua teoria do conceito, usa a noção de representação profusamente. Embora Dahlberg desenvolva uma teoria dos conceitos pragmática, de como estes podem aparecer na linguagem, em várias ocasiões ela deixa claro que a natureza do conceito está em refletir a verdade da realidade exterior. A influência da uma visão cognitivista da representação fica patente quando ela utiliza Engelkamp $^{12}$ para sustentar essa versão da natureza do conceito. Segundo ela, Engelkamp "descreveu o processo interno de formação dos conceitos" (DAHLBERG, 1978b, p. 11). Dahlberg faz a ressalva que Engelkamp trabalha com a percepção visual, mas faz a seguinte citação:

Nossa percepção [...] consiste numa representação icônica direta (por meio de imagens e figuras) do mundo óptico que nos circunda. Esta forma de representação é considerada mais elementar

\footnotetext{
${ }^{10}$ Independentemente de essa divisão paradigmática estar correta ou não, o uso da noção cognitivista de representação apareceria nos dois paradigmas (isto é, na literatura da área assim dividida).

${ }^{11}$ Dahlberg foi uma bibliotecária alemã e filósofa, que criou uma teoria analítica do conceito, de amplo uso em Ciência da Informação. A teoria dela se baseia na análise das relações lógicas e na estruturação destas em hierarquias. Os conceitos são identificados como objetos, e estes podem ser gerais (sua caracterização se aplica a vários objetos) ou individuais (a aplicação no tempo e no espaço de características gerais). "Universidade" seria assim um objeto geral e "Universidade de São Paulo" seria um objeto individual. Todo enunciado sobre um objeto, portanto, deve ser analisado para que as características aludidas a ele o descrevam adequadamente como geral ou particular. Definir bem essas características, então, é o cerne de uma análise conceitual. Realizar a síntese dessas características de forma sucessiva até ser o mais geral possível forma uma categoria. Esta seria a principal tarefa: definir bem as características de uma categoria, uma vez que elas não possuem uma realidade no espaço e no tempo, e é a caracterização dos casos possíveis que a tornam aplicável como categoria.

${ }^{12}$ ENGELKAMP, J. Satz und bedeutung. Stuttgart: W. Kolhammer, 1976.
} 
do que a que é constituída pela representação simbólica. Característica da representação icônica é ser ela concreta e plástica e distribuída em unidades. [...] A formação dos símbolos tem por base os dados da percepção [...].

Dos dados da percepção são abstraídos todos os aspectos possíveis que constituem os predicados, sejam eles quais forem. [...] $\mathrm{O}$ que armazenamos em forma abstrata como se fossem átomos da estrutura de nosso conhecimento são exclusivamente predicados, e as unidades elaboradas também em forma abstrata em nossa memória simbólica, ou seja, semântica, são configurações desses mesmos predicados. Os dados da percepção determinam quais os predicados que devem ser reunidos nas unidades semânticas abstratas. A unidade semântica abstrata tem a função de reunir um número de dados da percepção como equivalentes funcionais. [...] (ENGELKAMP apud DAHLBERG, 1978b, p. 11-12, grifos nossos).

Na citação de Dahlberg está presente o tripé dados-informação-conhecimento, embora parcialmente, no qual a informação é substituída pela noção de representação, através da qual os dados são convertidos em informação para compor unidades significativas. É claro aqui o papel da representação como um verdadeiro mecanismo mental, assim como também fica evidente o papel do cognitivismo nesta visão da mente como pertencendo exclusivamente a uma esfera individual que se conecta com os dados da realidade circundante. Isso tem uma enorme influência na proposta sobre a natureza dos conceitos, como destaca Dahlberg na conclusão de Engelkamp: "os conceitos são feixes de predicados que permitem reunir os dados ou a realidade em classes" (ENGELKAMP apud DAHLBERG, 1978b, p. 12). A partir dessa premissa dos dados da realidade como condutores da informação, Dahlberg presumirá todos os outros domínios da experiência humana como modulados pela informação possível representada nos conceitos.

Esta conclusão [de Engelkamp] que derivou apenas da experiência visual pode ser alargada para outros campos do conhecimento e para outros objetos, sejam eles elementares, como os sentimentos, sejam abstratos, como os produtos do nosso pensamento e de nossas inferências (DAHLBERG, 1978b, p. 12).

A par com a noção de representação, Dahlberg trata os conceitos não só como entidades estáveis (porque ancorados nos dados), mas pressupõe também a condição essencial de que as diferenças foram equacionadas o suficiente para se ajustarem como uma unidade à realidade.

Existe, todavia, uma condição para que os conceitos, ou, antes deles, os predicados, possam ser usados em uma comunicação 
intersubjetiva: devem orientar-se pelo postulado da verdade, isto é, devem corresponder à realidade e serem verificáveis. Quando determinado predicado possui tal caráter, então surge um elemento cognoscitivo relacionado com o objeto pensado, ou seja, um elemento de conhecimento. A reunião dos elementos do conhecimento por objeto conduz às unidades do saber (átomos ou moléculas do conhecimento). (DAHLBERG, 1978b, p. 12).

Desta perspectiva, uma definição de conceito passa pela redução de possibilidades de sentido para que possa ser intersubjetivo, isto é, as diferenças nas representações precisam ser equalizadas para que possam ser equivalentes entre os indivíduos. Assim, a formação dos conceitos fica restrita a uma "síntese dos predicados necessários verdadeiros a respeito de determinado objeto" (DAHLBERG, 1978b, p. 12). Apesar da formulação de conceito em Dahlberg ser colocada como uma superação do mentalismo presente na formulação de Wüster do conceito como "uma unidade de pensamento", ela compartilha com ele uma visão representacionista do processo do conhecer. Isso acontece porque, na teoria de Dahlberg, a "unidade de conhecimento" não se processa de forma autônoma na linguagem, mas segue a ideia clássica da linguagem como instrumento de comunicação do que se passa na mente.

Conceito é a unidade de conhecimento que surge pela síntese dos predicados necessários relacionados com determinado objeto e que, por meio de sinais linguísticos, pode ser comunicado. (DAHLBERG, 1978b, p. 12).

A definição de conceito apresentada acima expõe a linguagem como um passo secundário, de comunicação. O núcleo da argumentação foca na representação das propriedades dos objetos, na justa "re-apresentação" das características essenciais destes. Ou seja, a comunicação torna-se tributária do processo de representação. Como afirma Dahlberg, "uma explícita verbalização das propriedades de um objeto é essencial, a fim de que seja possível a comunicação intersubjetiva do mesmo objeto" (DAHLBERG, 1978b, p. 12). Uma variação dessa ideia encontramos na formulação de conceito de Barité como "abstração ou noção que se refere a uma unidade de conhecimento, independente de sua expressão linguística, e compreende o conjunto de suas características essenciais" (BARITÉ, 2000, tradução nossa) ${ }^{13}$. As normas para construção de tesauros supõem, por seu turno, que a unidade da representação é mental (uma "unidade de pensamento"), que se forma mentalmente combinando algumas ou

\footnotetext{
${ }^{13}$ [...]Abstracción o noción que se refiere a uma unidad de conocimiento, independiente de su expresión
} lingüística, y compreende el conjunto de sus rasgos esenciales. (BARITÉ, 2000). 
todas as características de um objeto (concreto, abstrato ou imaginário), independente de qualquer uso que se faça dessas unidades na linguagem (ANSI/NISO Z39.19:2005; ISO 25964-1:2011). Dessa perspectiva, portanto, a comunicação intersubjetiva só é possível se as representações que os indivíduos guardam em suas mentes coincidirem.

A partir dessas considerações, surge um quadro para começarmos a tratar do questionamento sobre a relação entre informação e conceitos. Primeiramente sobre como essa relação é pensada em Ciência da Informação. Como argumentamos até agora, essa relação não é colocada teoricamente, mas conotada como algo que acontece enquanto se processam as representações, portanto, compartilhando com estas a mesma natureza funcional. Dessa perspectiva, a noção implícita de informação que emerge é a de uma possibilitadora das características de estabilidade e unidade dos conceitos através das representações. Assim, a concepção que surge é a da informação como modulação, o que ela realiza equalizando diferenças para permitir a equivalência entre as representações dos indivíduos e consequentemente possibilitando a comunicação intersubjetiva dos conceitos. Secundariamente, teríamos que considerar como esta noção implícita de informação se relaciona com o processo de formação dos conceitos. Para isto, precisamos ir além da "acepção relativamente incontroversa - e fraca - de representação como construção" (MAGRO, 1999, p. 32), na qual a representação reconstrói o mundo de modos diversos, num jogo se substituições, como a substituição do gato no tapete pela expressão "o gato está no tapete". Precisaremos rever como a noção de representação joga um papel na teoria cognitiva sobre a categorização ${ }^{14}$ dos fenômenos no mundo. O ponto crucial, então, é quando se passa dessa concepção mais fraca (a representação como uma construção) para os compromissos epistemológicos que moldam a teorização da noção de conceito através da noção de representação. Principalmente quando se depreendem dessa noção como funcionam a linguagem e a comunicação.

\footnotetext{
${ }^{14}$ É o processo pelo qual se reconhece objetos ou fenômenos como possuindo similaridades que os agrupam sob uma denominação (identificando-se esta como uma classe). Um processo sistematizado de categorização compõe uma classificação, ou seja, um sistema de classes que é aplicado ao reconhecimento de objetos ou fenômenos. A categorização é um processo fundamental na formação dos conceitos uma vez que um conceito passa a existir em razão de sua diferença em relação a outros conceitos, o que só pode ocorrer quando são reconhecidas as similaridades (nas características do objeto/fenômeno observado) que o tornam distinguível (como classe de objetos e/ou fenômenos) de outros grupos de similaridades (outros conceitos). Uma categoria se inscreve como uma descrição mais precisa (ou formalização) das características de uma classe, mas não se confunde com o processo de categorização uma vez que este é fluido e a categoria é defendida como uma definição, portanto, é um processo ulterior de tentativa de fixação de sentido.
} 
Magro (1999), a partir de um texto de Shanon ${ }^{15}$, destaca três variações da noção de representação no discurso científico:

1. Uma variação de caráter epistêmico, na qual as representações são um substrato do significado. Por causa desse caráter, seu âmbito de discussão seria principalmente o filosófico, e a sua base argumentativa é de que:

[...] O comportamento humano exibe significação, é ordenado e regrado, o que atesta o conhecimento do mundo. Argumenta-se que, para que o comportamento aberto (como a enunciação de palavras e sentenças adequadas) seja significativo, ele deve ser a expressão de um substrato encoberto encarregado de tornar esse significado e tal regularidade possíveis - um papel que é desempenhado pelas representações. Há representação de tudo: de palavras, de conhecimento, de regras. (MAGRO, 1999, p. 33).

Ainda segundo Magro, esta variação estaria presente na Linguística sob a concepção da linguagem como "um sistema de regras subjacentes responsável pela estabilidade do comportamento verbal adequado dos falantes-ouvintes" (MAGRO, 1999, p. 33). Também estaria presente nas pesquisas sobre Inteligência Artificial em seus primeiros trinta anos (modelos representacionais), assim como na psicologia de Fodor, o qual também é usado em Ciência de Informação para sustentar a visão de que a definibilidade dos conceitos é uma abordagem válida (FRANCELIN, 2010, p. 80).

2. A segunda variação é a argumentação sobre o caráter funcional das representações, tendo estas a capacidade de mediação entre o meio e o indivíduo. Magro destaca duas ordens de argumentos que, dependendo das noções de organismo e ambiente envolvidas, podem ser invocados para explicar essa mediação:

a) para explicar a não-univocidade entre estímulo ambiental e resposta individual, assumem-se as representações como funções mediadoras entre o input e o output manifesto;

b) como a redução da psicologia à biologia pode trazer mais prejuízos que benefícios, tanto conceituais quanto operacionais, postula-se intermediários epistêmicos entre o nível da fisiologia e o da fenomenologia psicológica, sendo seus constituintes as representações.

\footnotetext{
${ }^{15}$ SHANON, B. The representational and the presentational: an essay on cognition and the study of mind. New York: Harvester Wheatsheaf, 1993.
} 
Nos dois casos, a proposta de não explicar o comportamento observado em termos de fatores externos e dados leva a atribuir-se ao ser que se comporta uma contribuição individual para o processo cognitivo, feita em termos de propriedades representacionais. Essa é a forma tradicional de se caracterizar a autonomia dos seres com respeito ao ambiente. $\mathrm{O}$ primeiro tipo de observação serve tanto à perspectiva dualista quanto à eliminacionista ou à reducionista do problema mente-corpo, mas o segundo caso atende às abordagens que optam por manter alguma forma de dualismo, ainda que possam eventualmente rejeitar o dualismo cartesiano, como é o caso do dualismo metodológico de Chomsky. (MAGRO, 1999, p. 33-34).

3. Finalmente, no contexto técnico-psicológico e na pesquisa da modelagem cognitiva, na qual as representações têm uma descrição precisa:

- $\quad$ simbólicas: têm duas faces, uma significante e outra de informação ou conteúdo;

- canônicas: sua formulação é feita em termos de um código pré-definido que é, ele próprio, completo e exaustivo, estruturado, de natureza sintática, envolvendo representações determinadas, de um só valor;

- estáticas: o conhecimento é especificado por uma estrutura representacional permanente, o que configura a mente como uma soma de todas as representações;

- abstratas: tanto o meio particular de sua articulação quanto o substrato particular no qual são instanciadas são imateriais;

- $\quad$ seus constituintes são bem definidos: compreendem um vocabulário que é decomposto em pequenos conjuntos de categorias chamadas primitivos, das quais as representações são estáveis;

- $\quad$ as composições resultantes são bem-formadas: ou seja, elas são compostas de acordo com um sistema de regras sintáticas. (MAGRO, 1999, p. 34).

Essas três versões sobre a natureza das representações têm em comum o fato de apresentarem uma visão proposional da mente (i.e., a mente seria um repositório de proposições sobre o mundo), e isso se reflete na teoria do conceito como uma invariância em suas diferentes abordagens na qual, ao fim e ao cabo, tudo gira em torno do comportamento declaratório a respeito de objetos. Especificamente em Ciência da Informação, esta visão se reflete num uso combinado do argumento epistêmico e funcional, que Magro denomina de argumento intencional, no qual "os agentes cognitivos se comportam pelo fato de terem crenças, desejos e objetivos, especificados por meio de representações; e do argumento funcional, na medida em que as representações constituem os recursos mais básicos que permitem ao agente exibir autonomia com relação ao ambiente" (MAGRO, 1999, p. 34). Isto é, os conceitos, formados intencionalmente, representam crenças, desejos e objetivos, através de 
declarações sobre estes, e estas podem ser comunicadas intersubjetivamente porque estas representações são recursos que todos os indivíduos possuem em comum a partir de um mundo perceptivo comum (como um recorte em comum das estruturas do mundo, uma eleição das propriedades essenciais e acidentais dos objetos - mas estas propriedades já estão lá, nas estruturas do mundo). O argumento intencional é o que sustentaria em Dahlberg (assim como em outros que seguem essa linha), a visão de que os conceitos passam a ser entidades viáveis quando estes representam declarações verdadeiras, verificáveis, sobre objetos (ou seja, representam declarações coincidentes entre os indivíduos sobre as propriedades essências dos objetos).

Por outro lado, não se confia que declarações plenamente livres (num exercício arbitrário que incorreria num risco de solipcismo) representem acuradamente o mundo, por isso, recorre-se a um processo básico - a categorização ${ }^{16}$ - como formador das unidades básicas do entendimento. Estas unidades são, como em Aristóteles, generalizações tributárias das estruturas do mundo.

No sistema aristotélico, as categorias servem de fundamento ao conhecimento das coisas. Elas são os princípios básicos que tornam o conhecimento possível, partindo de uma perspectiva que concebe o mundo como um todo integrado de causas e efeitos, em que as coisas e as suas propriedades essenciais, seus estados, processos e relações podem e devem ser reveladas pelo trabalho intelectual. (ARANDALE, 2009, p. 91).

A intencionalidade declaratória possuiria um limite, que em Dahlberg fica expresso na tipologia das características marcadas pelas categorias (Dahlberg, 1978c, p. 103). Nesse trabalho sobre a teoria do conceito, Dahlberg dá conta das 10 categorias $\operatorname{aristotélicas~}^{17}$, mas fica em aberto a existência de variações baseadas na combinação entre estas categorias. Porém, revelar o mundo através da linguagem tem, em Aristóteles, um significado representacional mais restrito:

\footnotetext{
${ }^{16}$ Processo que deveria levar, sob o ponto de vista representacionista, à fixação de categorias.

${ }^{17}$ Matéria (substância): de madeira, de metal, de couro, de vidro, etc.

Qualidade: possuir determinada estrutura, determinada forma, ser redondo, denso, colorido, etc.

Quantidade (extensão): possuir comprimento, largura, peso, etc.

Relação: ser o dobro, ser mais largo, ser causa de, ser condição de, etc.

Processo (atividade): começar, continuar, terminar, realizar algo, etc.

Modo de ser: estar em pé, sentado, voando, etc.

Passividade: ser cortado, pressionado, etc.

Posição: estar em cima, em baixo, etc.

Localização (lugar): estar em Brasília, no Rio de Janeiro, etc.

Tempo: em fevereiro de 1978, etc. (DAHLBERG, 1978c, p. 103).
} 
A substância é o ser no sentido primeiro e fundamental e, por esta razão, figura no topo da lista das categorias. As oito categorias são recortes que o pensamento humano faz da realidade, sendo elas um produto lógico, isto é, um produto do pensamento e de sua expressão, a linguagem, fidelíssimo às junturas existentes na própria realidade. Isto é possível, pois, aos olhos de Aristóteles, a linguagem está perfeitamente colada ao mundo, sendo, assim, capaz de revelá-lo. (ARANDALE, 2009, p. 91).

Desta noção epistêmica de representação, como substrato de toda significação (e, por extensão, da linguagem), passou a fazer parte da história do pensamento ocidental sobre os conceitos, e no seu extremo ensejou a ideia do Círculo de Viena sobre a natureza da linguagem: "O Círculo de Viena e todo o neopositivismo primário herdam de Russel e Wittgenstein a ideia de um isomorfismo total entre linguagem e realidade" (MARRADI, 2012, p. 37, tradução nossa) ${ }^{18}$.

A abordagem intersubjetiva de Dalhberg para a construção do conhecimento parece entrar em contradição com uma ideia de isomorfismo entre linguagem e mundo, mesmo porque, como afirmamos anteriormente, a autora contrasta sua teoria ao mentalismo de Wüster (que defende uma ligação forte entre termos e fatos no mundo). De qualquer forma, Dahlberg se baseia principalmente em Aristóteles na sua abordagem do processo de categorização. Pode-se fazer uma ilação aqui que a noção implícita de informação "como algo que afeta a mente", seja desde os dados do conhecimento ou da realidade em si, encontra-se subjacente a duas concepções de representação contraditórias, a saber: a construção do conhecimento através da intersubjetividade na linguagem e conhecimento como uma representação direta do mundo.

A partir das considerações até agora realizadas, podemos esboçar uma correlação entre a articulação das noções de representação e a articulação nas noções de informação que se constroem sob o paradigma representacionista na organização e representação do conhecimento. Esta correlação estaria subdividida entre as noções mais fracas ou fortes de informação e as noções mais fracas ou fortes de representação. Por fracas ou fortes estaremos julgando o peso dado a cada uma na formação da cognição, e consequentemente na formação dos conceitos. Uma noção fraca de informação seria aquela na qual a informação não possui um papel ativo na cognição, ou seja, não possui uma fenomenologia (não possui papel explicativo no fenômeno cognitivo). Quando a noção de informação é fraca, cria-se um vazio teórico que é

${ }^{18}$ The Vienna Circle and all the early neopositivism inherit from Russel and Wittgenstein the Idea of a total isomorphism between language and reality". (MARRADI, 2012, p. 37). 
preenchido pelo seu correlato, a representação, que ganha peso explicativo. Conceitos muito generalistas de informação, em que ela pode ser tudo ou nada ao mesmo tempo, são fracos nesse sentido, eles não especificam o que devemos observar para dizer que estamos falando de informação, mas se prendem a ocorrências atreladas ao processo de representar, como em Buckland:

[...] Wersig (1979) adotou uma visão mais limitada de informação como sendo derivada de três fontes: (1) "Gerada internamente" pelo esforço mental; (2) "Adquirida pela percepção pura" do fenômeno; e (3) "Adquirida pela comunicação". Entendemos "informação-comocoisa" como correspondente a duas fontes apontadas por Wersig, ao fenômeno (2) e comunicações (3). (BUCKLAND, 1991, p. 6).

O problema dessa afirmação não está em a informação "ser-como-coisa" (reduzida a objetos), mas em ser indeterminada, aplicável a qualquer "coisa que seja informativa", como o autor confessa ao fim. É um problema que se repete em Zins (KNOWLEDGE map..., 2006), apesar de sua conceituação (a informação como um conhecimento empírico) ser até oposta à de Buckland. A questão de fundo é que a informação, assim fracamente conceituada, acaba funcionando como uma transparência para a cognição, para revelar aquilo que deveria ser representado. Trata-se de uma função da qual se ignoram as bases de sua própria funcionalidade e que mesmo assim produz efeitos: "quando alguém é informado, aquilo que conhece é modificado" (BUCKLAND, 1991, p. 1, grifo nosso). Sobre o porquê dessa modificação não são dados argumentos, o que poderia transformar o conceito fraco de informação em forte. Um deslocamento conceitual equivocado que é feito para suprir essa lacuna é a invocação da Teoria da Informação (SHANNON; WEAVER, 1975) para justificar a informação "como uma transferência de conteúdos". Porém, isso seria realizar uma confusão entre domínios: a teoria de Shannon não trata de informação cognitiva ${ }^{19}$. A ideia de informação como fluxo deriva desse deslocamento, mas como não aponta qual o mecanismo desse fluxo (que em TI é a configuração de estados bi-estáveis) segue o mesmo caminho de generalização que "informação como coisa", "como algo que afeta a mente" ou "como conhecimento" compartilhado. Desse estado de debilidade conceitual é que emerge fortalecida a noção de representação, como repositória e reguladora dessas informações que estão aí para serem captadas, mas que só ganham organização e funcionalidade quando sistematizadas como representações.

\footnotetext{
${ }^{19}$ Nos capítulos seguintes abordaremos adequadamente essa teoria, seu contexto e sua relação com uma abordagem sistêmica da informação cognitiva.
} 
O preço desse desequilíbrio é que a noção de representação pende para o cognitivismo uma vez que a intersubjetividade passa a depender de isomorfismos entre as representações "estocadas" na mente. A mediação, portanto, acaba perdendo espaço ou gravitando em torno de preocupações como o processo de representar "o que existe em comum" entre a cognição humana e o mundo (e entre os indivíduos). Nessa situação, qualquer elaboração sobre a mediação do sentido termina por ser alinhada, mais cedo ou mais tarde, às questões sobre representações objetivas e subjetivas, o que implica, por sua vez, em valorar ou desvalorizar discursos.

Uma noção mais fraca de representação, por outro lado, em que esta é repensada em termos de apropriação e reelaboração de mediações, seria um remédio para esse desequilíbrio se elaborasse igualmente uma noção de informação nos mesmos termos. Aqui, então, chegamos à questão do que seria uma noção forte de informação e, assim também, a uma baliza para a elaboração de uma noção coerente de representação como mediação de sentido. A questão-chave dessa noção é como o papel da informação é colocado na construção de realidade. Se, nessa construção, a informação possuir um papel dicotômico, isto é, se ela for ativa na construção do sentido (nas interações sociais), mas inativa na construção da percepção (como na relação passiva “dados" $\rightarrow$ informação), então ainda se terá como resultado uma noção fraca de informação. A baliza, portanto, seria quando na noção de informação a percepção e o sentido são construídos em conjunto e, ademais, são distinguidos entre si por meio da distinção do que são em termos de realização da informação. Tal junção é, no entanto, rara porque pressupõe se desvencilhar das noções positivistas, ainda tácitas, sobre a percepção no campo científico. E esse positivismo ainda é ativo também nas ciências sociais.

[...] a constituição das ciências sociais teve lugar segundo duas vertentes: uma mais diretamente vinculada à epistemologia e à metodologia positivista das ciências naturais, e outra, de vocação antipositivista, caldeada numa tradição filosófica complexa, fenomenológica, interaccionista, mito-simbólica, hermenêutica, existencialista, pragmática, reivindicando a especificidade do estudo da sociedade, mas tendo, para isso, [que] pressupor uma concepção mecanicista da natureza. (SANTOS, 1988, p. 42).

Como ciência social aplicada, a Ciência da Informação também ainda se encontra sob influência do positivismo. Em tese recente sobre a ordenação 
epistemológica dos estudos sobre o conceito em Ciência da Informação, Francelin constatou uma tendência majoritária de artigos sob influência do positivismo.

A maior parte dos artigos, como demonstrado, está relacionada diretamente a questões operacionais em torno do conceito. Nesta perspectiva, existe um corpo teórico-metodológico constituído por pesquisas já sedimentadas na área de Organização da informação e do conhecimento no Brasil. As principais abordagens destas pesquisas estão pautadas na relação entre a Teoria (analítica) do conceito, a teoria da classificação facetada, a Teoria geral da terminologia e a ontologia. Dessa forma, autores como Dahlberg, Ranganathan, Wüster e Guarino são presença constante nos artigos analisados. Voltados para a organização de sistemas de conceitos, as linhas de força teóricas destes artigos estão calcadas, fundamentalmente, na lógica aristotélica, melhor representada pelas categorias, e pelo princípio de fixação da linguagem ou conceito por meio de juízos e proposições verdadeiras, características básicas da filosofia analítica e do positivismo lógico. (FRANCELIN, 2010, p. 180).

Seria necessário, portanto, construirmos dentro do campo da organização do conhecimento o uso de uma noção forte de informação, de construção da experiência da realidade (percepção $e$ sentido). De outros campos da Ciência da Informação, todavia, propostas de conceitos de informação mais relativísticas e construtivistas que podem ser trazidas para o campo da organização do conhecimento. Kobashi e Tálamo, por exemplo, conceituam informação como um objeto de estrutura relacional (KOBASHI; TÁLAMO, 2003). Entre estas, ganha destaque a de Capurro por circunscrever a realização da informação em algum sistema, assim possibilitando diferenciar percepção e sentido através da informação (numa conceituação mais forte de informação).

O sociólogo alemão Niklas Luhmann desenvolveu um conceito de informação baseado na teoria dos sistemas autoreferentes. Luhmann (1997) distingue entre sistemas biológicos e sociais (e psíquicos). Os sistemas sociais (e psíquicos) são constituídos por significado (Sinn). No caso dos sistemas biológicos, a auto-referência significa uma auto-reprodução. O significado é produzido através das diferenças de processos, e isto é possível porque há uma oferta de significado (Mitteilung) fora da seleção que pode ser feita. A informação (Information) é, então, um evento que produz uma conexão entre diferenças ou - Luhmann cita a definição famosa -, de Bateson (1972, p. 459) "uma diferença que faz diferença" [...]. (CAPURRO, 2007, p. 25, grifo nosso).

Contudo, na análise de como a Ciência da Informação está dividida paradigmaticamente esta concepção de informação não é colocada por Capurro como um divisor entre os paradigmas, sendo utilizada outra abordagem, dentro da qual não se 
faz menção ao paradigma representacionista. Por este motivo, não utilizamos a divisão em paradigmas de Capurro (2003) para separar as propostas de informação, porque concluímos que sua débil capacidade de encerrar programas de pesquisa como sendo categoricamente de um paradigma físico, cognitivista ou social demonstra que essa divisão não revela como as diversas noções de informação se articulam através desses paradigmas. Se esses paradigmas podem ser usados concomitantemente é porque de fato nenhum deles é usado como um exemplar de orientação na pesquisa, portanto, nenhum deles revela em seu bojo uma noção de informação que se impõe, mas antes uma metáfora qualificadora de programas de pesquisa como físicos, cognitivistas ou sociais $^{20}$.

Nesse sentido, nossa proposta é desconstruir primeiro a abordagem fraca de informação, analisando-a naquilo que ela afirma: que a informação, a partir das percepções, informa a mente sobre o estado do mundo (suas propriedades e relações). Tal afirmação, por ser uma variação do argumento da mente como um sistema aberto será cotejada primeiro com a própria noção de sistema ${ }^{21}$, e em sequência com a noção de sistemas abertos e fechados. A vertente teórica da abordagem representacionista da informação será examinada a partir da concepção comunicativa desta, da informação como uma comunicação que pode ser equalizada como uma mensagem num canal, e do pressuposto da natureza da mente como sendo proposional. Nessa segunda etapa, portanto, o que será examinado será o suposto caráter objetivo/subjetivo da comunicação em sua relação com a linguagem e com a noção de intersubjetividade (essencial para se analisar a formação e comunicação dos conceitos). Tal percurso implicará em se retrabalhar as noções de comunicação, linguagem e intersubjetividade comumente apresentadas sob o paradigma representacionista da informação. Igualmente, será necessário advertir aqui que não é fácil se desvencilhar do termo "representação" (e nem o pretendemos), uma vez que é tão difundido quanto o termo informação, por isso, doravante entenderemos (e procuraremos construir a noção) que uma representação é o resultado de uma observação que trazemos à mão quando usamos a linguagem (representação enquanto mediação de sentido), plenamente contingente ao seu uso, e não um processo de representar algo, e muito menos um mecanismo mental.

\footnotetext{
${ }^{20}$ Sobre essa dificuldade da divisão paradigmática de Capurro, ver Campos e Venâncio (2007).

${ }^{21} \mathrm{E}$, por esa razão, nosso intuito será o de delinear uma abordagem sistêmica da informação, em grande parte baseada na proposta de Luhmann, mas não limitada a esta (quando necessário aspectos críticos serão revistos) - a pretensão é a de uma proposta em aberto.
} 
O objetivo dessas análises será o de encontrar um novo patamar epistemológico para a compreensão da formação dos conceitos não mais a partir da abordagem representacionista da informação. Compreendemos que a natureza dos conceitos tem sido encarada como um recorte da realidade, uma representação em segunda-mão desta. E sobre o corpo teórico que sustenta essa visão, poderíamos afirmar que "a maioria das teorias de conceitos não se afastaram grandemente da imagem de um conceito como algo inteiramente pré-definido, que, quando usado, é simplesmente ativado, como a ignição de um motor ou o apertar do interruptor de luz" (GABORA; ROSCH ; AERTS; 2008, p. 110, tradução nossa) ${ }^{22}$. A abordagem que iniciaremos, da informação como um processo que participa da constituição dos sistemas que observamos, procurará estender aos conceitos a noção de constructos da realidade. Procuraremos, portanto, ver os conceitos "não como representações fixas ou identificadores, mas, isto sim, como pontes entre a mente e o mundo que participa da geração de significado" (Ibid., p. 110, tradução nossa) ${ }^{23}$.

22 "[...] Most theories of concepts have not strayed far from the image of a concept as something entirely predefined, which, when used, simply gets turned on, like the starting of a motor or the flicking of a light switch". (GABORA; AERTS; ROSCH; 2008, p. 110).

23 "[...] Not as fixed representations or identifiers but rather as bridges between mind and world that participate in the generation of meaning" (Ibid., p. 110). 


\section{Capítulo 2}

\section{A Abordagem Sistêmica da Informação}

As noções de sistema e informação são cruciais para se compreender não só a natureza da Ciência da Informação enquanto disciplina, mas também fazem parte da preocupação de todas as disciplinas que procuram explicar tanto o mundo quanto o papel do ser humano nele. É, portanto, um grande desafio tentar esclarecer a natureza desses dois conceitos. A primeira tarefa que se impõe nesse esclarecimento é posicionarse quanto à maneira como abordaremos o problema de explicar dois conceitos que têm significado e usos tão diversos para tantas disciplinas e ramos do saber humano. Inventariar todos esses significados e usos seria uma tarefa, na prática, interminável, mesmo que apenas circunscrita à Ciência da Informação. Portanto, nossa abordagem dos conceitos sistema e informação será uma reflexão crítica em torno dos problemas e objetivos traçados previamente: como informação e cognição geram o fenômeno do conhecimento (no qual categorias e conceitos são instâncias especiais).

Essa abordagem leva, primeiramente, a uma distinção importante: sistema e sistêmico serão usados aqui enquanto uma teoria geral, aplicável inclusive à comunicação e à teoria da mente. Esta última observação é central à nossa abordagem porque o conceito de informação será analisado, primordialmente, de um ponto de vista sistêmico. Uma das dificuldades é de ordem terminológica, uma vez que, em Ciência da Informação, a noção de sistema está historicamente ligada à noção de "sistema de informação" como o complexo de técnicas e tecnologias usado para guardar, recuperar e transmitir as informações digitais sobre os documentos ou os próprios documentos, quando digitalizados. Essa identificação, inclusive, leva a inferir a abordagem sistêmica com o "racionalismo sistêmico" cuja linearidade não condiz com a natureza da comunicação humana e da documentação como fenômeno linguístico (GONZÁLEZ DE GOMEZ, 2004). Outras concepções de sistema praticamente não aparecem, em Ciência da Informação, pelo menos enquanto $\operatorname{conceito}^{24}$ aplicado, apesar de, mesmo no

\footnotetext{
${ }^{24}$ Enquanto crítica, Venâncio e Borges $(2006$, 2008) elaboraram trabalhos confrontado o entendimento clássico de sistema, assim como o entendimento errôneo (sistema apenas como sistema de informações
} 
alvorecer da Teoria Geral dos Sistemas, Ludwig Von Bertalanffy, o principal propositor da teoria nos anos 1940, já ter apresentado uma conceituação de sistema que não se limitava às máquinas:

O conceito da natureza até agora predominante acentuava a resolução dos acontecimentos em cadeias lineares causais, a concepção do mundo como resultado de acontecimentos causais, um "jogo de dados" físico e darwinista (Einstein) e a redução dos processos biológicos às leis conhecidas da natureza inanimada. Por oposição a este ponto de vista, na teoria dos sistemas abertos (a sua mais recente generalização na teoria geral dos sistemas), tornam-se visíveis os princípios de interação entre múltiplas variáveis (por exemplo, cinética das reações, fluxos e forças na termodinâmica irreversível), uma organização dinâmica de processos e a possível expansão das leis físicas ao domínio biológico. Portanto, estes desenvolvimentos formam parte de uma nova formulação da concepção científica do mundo (BERTALANFFY, 1973, p. 208-209).

Bertalanffy também apontava a necessidade de se ajustar a noção de sistema para englobar os fenômenos psíquicos, linguísticos e culturais e que o princípio humanista das funções simbólicas é fundamental na consideração da teoria dos sistemas (BERTALANFFY, p. 291, 1973). Em trabalho anterior (DERQUI, 2004), porém, já tínhamos abordado o problema da conceituação de sistema, no qual acusávamos que as primeiras propostas de incluir o fenômeno do vivo na teoria dos sistemas abertos tinham levado a mal-entendidos sobre a aplicação da teoria geral dos sistemas nas questões da informação e do conhecimento:

Uma concepção comum sobre a mente, tanto em CI quanto em outras disciplinas, concebe que "a human thinking system is an open system [o sublinhado é nosso] that interacts with its enviroment via a physical symbol subsystem" (Liang, 1998, p. 278). Essa concepção baseia-se em um paralelo que se realiza entre o sistema cognitivo e os sistemas mais gerais que compõem o corpo vivo. De fato, tanto no senso comum quanto na pesquisa científica, tem se alicerçado a noção de que a vida é um "sistema aberto". O problema, porém, está em entendermos o que queremos dizer quando falamos que a vida é um sistema aberto. (DERQUI, 2004, p. 47).

Nesse trabalho, nosso propósito foi discutir como se podia entender a informação e o conhecimento a partir de seus fundamentos biológicos, ou seja, como a organização do vivo se reflete na organização da cognição. Nesse estudo, afirmamos que a noção de sistema possui contornos mais complexos, e que principalmente seres

digitais), com o entendimento emergente sobre sistemas auto-organizados (tema a ser tratado mais adiante). 
vivos, e por consequência sua cognição, podem ser entendidos como sistemas, mas sistemas longe do equilíbrio, que autoproduzem sua própria diferenciação em relação ao meio. Concluiu-se que uma nova compreensão de informação e conhecimento deve ser alcançada levando em conta um novo panorama para a noção de sistema, alicerçado nas abordagens científicas emergentes que passaram a incluir a complexidade e a intersubjetividade, mas que a Ciência da Informação carece de uma abordagem paradigmática para tanto. Argumentávamos que a Ciência da Informação ainda está presa em uma abordagem representacionista do processo de informação e que, mais do que um paradigma orientador da pesquisa, tal postura é a aceitação tácita de um dualismo observador/objeto no qual informação não possui nenhuma definição ontológica, mas propostas intercambiáveis tais como "informação como coisa" ou “informação como algo que afeta a mente”. Em razão dessa carência de uma abordagem paradigmática do fenômeno da informação em Ciência da Informação é que se torna útil primeiro conhecer quais são as possibilidades de se entender a Ciência da Informação como "possuidora de um paradigma", e como isso se relaciona com uma abordagem sistêmica da informação, da comunicação e do conhecimento. Embora a própria noção de paradigma seja questionável em Ciência da Informação ${ }^{25}$, como afirmamos no capítulo precedente, uma vez que não se consegue apontar estudos motivados por mudanças paradigmáticas ou a existência de competição entre diferentes paradigmas (CAMPOS; VENÂNCIO, 2007), esta noção permanece em uso como forma de tratar abordagens epistemológicas diferentes dentro da Ciência da Informação, no mínimo "no sentido de exemplaridade existente na concepção de paradigma ao se admitir o caráter de modelos ou esquemas presente no conceito de abordagem" (CAMPOS e VENÂNCIO, 2007, p. 108).

Entre os autores que atualmente trabalham em Ciência da Informação com a noção de paradigma como forma de compreender epistemologicamente esta disciplina, está o pesquisador Rafael Capurro, e que propôs uma abordagem sistêmica da informação (citada à página 29). Essa proposta, embora breve e não retomada em outros trabalhos desse autor ${ }^{26}$, traz à Ciência da Informação uma noção de sistema que não cai em reducionismos ou limita-se a um "racionalismo sistêmico". A proposta de Capurro sobre informação como uma seleção de sentido realizada no marco de um sistema

\footnotetext{
${ }^{25}$ Especificamente a divisão entre paradigmas físico, cognitivo e social, como postulado por Capurro.

${ }^{26}$ De fato, a proposta de informação de Capurro não é articulada com a sua proposta de divisão paradigmática da disciplina Ciência da Informação.
} 
(psíquico/social) é a proposta sistêmica de Luhmann, a qual não cai no erro das abordagens pseudo-sistêmicas de propor uma visão holística para os fenômenos sistêmicos, mas vê o sistema como um todo organizado no qual as partes emergem das especificidades de suas próprias operações. Ou seja, a informação, em vez de ser algo que tem propriedades que se manifestam de um mesmo modo em todas as escalas da experiência, é um fenômeno que emerge junto com o sistema na escala específica da experiência nesse sistema. Capurro, porém, não especifica esse detalhe em sua proposta, assim como não específica uma explicação de sistema que compreenda também uma explicação de como a informação emerge nos sistemas psíquicos e sociais. Essa falta tem como consequência que a proposta não só fica incompleta como também pode gerar mal-entendidos, uma vez que a noção de sistema não é pacífica e como afirma Esteves de Vasconcellos (2010) essa noção pode ser entendida de forma diametralmente oposta dependendo da perspectiva paradigmática.

A proposta de sistema de Luhmann, utilizada por Capurro para a construção do conceito de informação, difere muito das propostas clássicas de sistemas abertos, e está muito mais próxima do "pensamento sistêmico" (ESTEVES DE VASCONCELLOS, 2010), do que da Teoria Geral dos Sistemas. Deixar claro tal diferença, em toda sua extensão, não só compatibilizaria a noção de sistema com o "paradigma social” de Capurro como também evitaria uma confusão com a perspectiva cognitivista que também trabalhou com a noção de sistema aberto (a cognição como um sistema aberto à informação complexa). Mas acima de tudo seria preciso diferenciar "sistema psíquico" de "sistema social", que na proposta de Capurro aparecem indistintos (mais por omissão do que por definição) como sistemas de sentido, mas que na elaboração de Luhmann possuem diferenças marcantes quanto ao modo como a informação é distinguida em cada sistema. A noção de informação como "seleção de sentido" não é homogênea nos dois sistemas, e a compreensão dessa diferença é fundamental para entender como o sentido é construído e, para os propósitos deste trabalho, como este sentido construído pode ser distribuído nos fenômenos da categorização mental (sistema psíquico) e da categorização social (sistemas sociais). Para se compreender, portanto, como a informação surge de cada um desses sistemas, abordaremos a seguir o conceito basal de sistema-informação, desde sua concepção clássica até as abordagens emergentes da auto-organização e da Biologia do Conhecer (ou Cognição Situada). 


\subsection{O Conceito de Sistema}

As concepções clássicas ${ }^{27}$ de sistema, ainda muito em voga, representaram, mesmo na sua vertente clássica, uma revolução paradigmática (ou epistemológica) para a história da ciência. Esse aspecto revolucionário é importante para entendermos seu impacto não só na ciência, mas na cultura também. Porém, como toda revolução no conhecimento, esta também não foi uma ruptura completa, e esse aspecto também é importante para entendermos porque se deu uma revisão de seus postulados por autores ligados ao próprio movimento que a teoria dos sistemas ensejou. Para entendermos o que foi essa revolução, primeiro analisaremos os postulados da ciência tradicional, e então como os postulados da teoria dos sistemas se contrapôs a estes.

Esteves de Vasconcellos (2010) realizou uma síntese do que seria o paradigma tradicional da ciência, que se assenta, em linhas gerais, em contrapor o paradigma da complexidade ao da simplicidade. Como a autora esclarece, o paradigma tradicional não é um paradigma ultrapassado, ele continua vigorosamente em uso, mesmo porque, para muitos campos do conhecimento, os postulados tradicionais são mais que suficientes. Também se pode associar o paradigma tradicional ao que se convencionou chamar de “ciência moderna" e o paradigma da complexidade à "ciência pós-moderna", mas esta última também é denominada como "ciência emergente" ou "ciência novoparadigmática". Do conjunto amplo de descrições que o paradigma tradicional mereceu em incontáveis estudos epistemológicos e da filosofia da ciência, a autora destacou três dimensões:

- $\quad$ SIMPLICIDADE (análise - relações causais lineares)

- ESTABILIDADE (determinação - previsibilidade reversibilidade - controlabilidade)

- $\quad$ OBJETIVIDADE (subjetividade entre parênteses - universo)

Essas três dimensões possuem as seguintes propostas:

1-O pressuposto da simplicidade: a crença em que, separando-se o mundo complexo em partes, encontram-se elementos simples, em que é preciso separar as partes para entender o todo, ou seja, o pressuposto de que o "o microscópico é simples". Daí decorrem, entre outras coisas, a atitude de análise e a busca de relações causais lineares.

2-O pressuposto da estabilidade do mundo: a crença em que o mundo é estável, ou seja, em que "o mundo já é". Ligados a esse pressuposto estão a crença na determinação - com a consequente previsibilidade dos fenômenos - e a crença na reversibilidade - com a consequente

\footnotetext{
27 Voltadas para a noção de equilíbrio: um sistema só existe em função do equilíbrio entre suas partes
} constituintes. 
controlabilidade dos fenômenos.

3-O pressuposto da objetividade: a crença em que "é possível conhecer objetivamente o mundo tal como ele é na realidade" e a exigência da objetividade como critério de cientificidade. Daí decorrem os esforços para colocar entre parênteses a subjetividade do cientista, para atingir o universo, ou versão única do conhecimento. (ESTEVES DE VASCONCELLOS, 2010, p. 69).

Em resumo, o paradigma tradicional da ciência "simplifica o universo (dimensão da simplicidade), para conhecê-lo ou saber como funciona (dimensão da estabilidade) tal como ele é na realidade (dimensão da objetividade)" (ESTEVES DE VASCONCELLOS, 2010, p. 93). Esses pressupostos sempre foram facilmente adotados pelas ciências físicas, mas as ciências biológicas tiveram dificuldade em adotar os pressupostos de simplicidade e de estabilidade (a estabilidade era especialmente conflituosa, já que o vivo está sempre em mutação); e as ciências humanas tiveram dificuldade em adotar os três pressupostos, principalmente o da objetividade e assim anular o sujeito e a subjetividade (Ibid., p. 99).

Quando as primeiras teorias sistêmicas ${ }^{28}$ surgiram, elas justamente lançaram um olhar de preocupação às lacunas que o pensamento científico tradicional deixava entre as disciplinas, tentando então um esforço teórico que alcançasse e abarcasse o fazer científico no todo (sunistemi - unificar, juntar - em grego). Bertalanffy, ao elaborar sua Teoria Geral dos Sistemas, estava interessado em incorporar a complexidade e a instabilidade dos fenômenos biológicos a uma teoria que também descrevesse o comportamento dos sistemas físicos. Norbert Weiner, ao propor sua Cibernética, estava explorando as conexões entre engenharia e comportamento humano, procurando, através da compreensão sistêmica do fenômeno da retroalimentação, uma teoria que inaugurasse uma ciência do controle tanto das máquinas quanto dos seres vivos (inclusive da comunicação humana). As teorias sistêmicas surgem, então, principalmente como um movimento teórico inverso ao da simplificação, buscando uma escala de compreensão na qual os fenômenos não são analisados analiticamente como compartimentados, mas como fazendo parte de uma totalidade. Essa abordagem é mais notável em Bertalanffy, que expressava inclusive uma preocupação maior com a natureza da ciência e do fazer científico, comparável às preocupações de Kuhn (2001) com os paradigmas da ciência. Bertalanffy se sentia especialmente incomodado com as

${ }^{28}$ Não faremos, neste estudo, um histórico da noção de sistema desde suas raízes na Filosofia ou deste conceito em seus primeiros usos na ciência, em razão da proposta deste trabalho ser centrado na noção de informação. 
divisões estanques na ciência, que contrapunham ciências físicas e biológicas, assim como ciências exatas e as ciências humanas, e queria que uma nova compreensão das leis físicas que compensasse isso.

Bertalanffy apontou a necessidade de novas categorias de pensamento científico, mais amplas, de modo que uma ciência rigorosa pudesse abarcar também a biologia e a sociologia. Ele postulou que a termodinâmica clássica, que lida com sistemas em equilíbrio ou próximos dele, precisaria ser complementada por uma nova termodinâmica que abarcasse também os sistemas abertos que se mantem longe do equilíbrio. (ESTEVES DE VASCONCELLOS, 2010, p. 195).

A Cibernética de Weiner, por outro lado, apesar de não buscar essa compreensão mais ampla da ciência, teve impactos mais profundos porque criou conexões entre as disciplinas da física, da biologia e das ciências sociais através do uso da noção de informação, que ele ajudou a sofisticar. Capra, por exemplo, diz que uma nova concepção de vida tem raízes mais claramente expostas na Cibernética do que na Teoria Geral dos Sistemas (CAPRA, c1996). Gregory Bateson e Margareth Mead também se entusiasmaram com a concepção (na Cibernética) de que a retroalimentação era o padrão geral da vida, com o qual se poderia descrever os sistemas organizados, biológicos e sociais (ESTEVES DE VASCONCELLOS, 2010, p. 236). A Cibernética, portanto, desafiava a fragmentação e o reducionismo da ciência tradicional ao propor $o$ tema da informação como unificador dos diversos campos do conhecimento. Por seu turno, a Teoria Geral dos Sistemas faria o mesmo ao propor o tema da organização, ao declarar que na natureza o importante não era a decomposição dos fenômenos em físicos, biológicos ou sociais, mas compreender a organização relacional dos elementos e como esta definia a unidade do sistema observado.

$\mathrm{O}$ fato de que os temas da informação e da organização tivessem ficado disjuntos nas primeiras propostas sistêmicas era, porém, um sintoma de que ambas as abordagens (de Bertalanffy e Weiner) não significavam um rompimento (completo) com o paradigma tradicional da ciência. Ainda presas ao primado do objetivismo, a Teoria dos Sistemas não é capaz de considerar um sistema organizado e funcional sem que este guarde algum isomorfismo com uma realidade pré-existente (ou seja, não é capaz de imaginar um sistema viável gerando e organizando toda sua informação), e a Cibernética, embora capaz de pensar em sistemas autorregulados e autônomos no gerenciamento de sua informação, não contempla a emergência de organização nova 
nos sistemas, restringindo-se a mecanismos pré-existentes. O conceito de sistema (que foi expresso mais explicitamente na obra de Bertalanffy) começa, portanto, no marco de um paradigma objetivista. Podemos desenhar esse conceito preliminar de sistema desde uma teoria da organização (Teoria Geral dos Sistemas) como separada de uma teoria da informação (Cibernética) nos sistemas. Como argumentaremos mais adiante, essa separação é a principal geradora de confusões nas propostas conceituais de informação, e, portanto, também perseguiremos neste trabalho uma compreensão conjunta do binômio sistema/informação.

Apresentamos primeiramente, então, as características que definem (na visão de Bertalanffy) um sistema quanto à sua organização:

- Um sistema é um complexo de elementos em interação, que;

- é definido, e só existe, em consequência das relações que estabelecem os elementos entre si;

- isso significa que os elementos $p$ estão em relações $R$ de tal modo que o comportamento de $p$ na relação $R$ é sempre diferente do seu comportamento na relação $R^{\prime}$;

- as relações são o que confere coesão ao sistema, assumindo este um caráter de totalidade ou globalidade como característica definidora de sistema;

- um sistema é um todo integrado, que deixa de existir como sistema quando analisado em suas partes constitutivas ou propriedades em separado, portanto um sistema só pode ser analisado por conjuntos de equações diferenciais simultâneas, não lineares;

- as relações entre os elementos são sempre interdependentes, portanto todas as interações podem ser caracterizadas como não unilaterais ou bidirecionais, funcionando assim o sistema sempre num regime de causalidade circular;

- todo sistema surge e se organiza como uma ordem estratificada, em relação a outros sistemas, pela superposição de níveis de hierarquia, e cada nova ordem não pode ser reduzida a uma ordem inferior, porque não compartilham a mesma organização, ou seja, um sistema só pode ser analisado a partir das próprias relações que o constituem.

- finalmente, há o princípio da equifinalidade, que rege os sistemas abertos, que diz que nestes um mesmo estado final - ou meta - pode ser alcançado partindo de condições iniciais diferentes e por trajetos também diferentes. Nos sistemas fechados um estado final só ocorre se este estiver inequivocamente determinado nas condições iniciais. (BERTALANFFY, 1973, p. 82-84).

O conceito de sistema na Teoria Geral de Bertalanffy é dedicado, assim, aos sistemas abertos, porque só estes mostrariam organização: uma totalidade em interação através de relações que se reforçam circularmente e capaz de manter um estado final estável. Um sistema aberto, porém, é negentrópico, isto é, aumenta sua complexidade estrutural ao consumir matéria e energia em fluxo, invertendo, assim, a entropia a que 
essa matéria e energia estariam destinadas no meio ambiente desse sistema. Como a Teoria da Informação utiliza a mesma matemática da distribuição de possibilidades utilizada na Termodinâmica para o cálculo da entropia, Bertanlanffy viu nisso um impasse teórico, que não só o impedia de explicar em termos de informação a complexidade crescente dos sistemas abertos (leia-se: sistemas vivos), como também se compunha como uma diferença incontornável entre sua proposta sistêmica e a da Cibernética, que se fundamenta na informação:

A base do modelo do sistema aberto é a interação dinâmica de seus componentes. A base do modelo cibernético é o ciclo de retroação no qual, por via da retroação da informação mantém-se um valor desejado (Sollwert), atinge-se um alvo, etc. A teoria dos sistemas abertos é uma cinética e uma termodinâmica generalizadas. A teoria cibernética baseia-se na retroação e na informação. Os dois modelos foram aplicados com êxito em seus respectivos campos. No entanto devemos ter a noção de suas diferenças e limitações. O modelo do sistema aberto na formulação cinética e termodinâmica não fala de informação. Por outro lado um sistema de retroação do ponto de vista termodinâmico e cinético é fechado, não possuindo metabolismo. Em um sistema aberto é possível termodinamicamente o aumento da ordem e a diminuição da entropia. A grandeza "informação" é definida por uma expressão formalmente idêntica à entropia negativa. (BERTALANFFY, 1973, p. 203-204)

Para Bertalanffy e a visão organicista de sistema, portanto, sistemas que lidam com a informação serão sempre fechados, uma vez que "em um mecanismo de retroação fechado a informação só pode diminuir e nunca aumentar, isto é, a informação pode ser transformada em "ruído", mas não vice-versa" (BERTALANFFY, 1973, p. 204). Deste modo, criava-se um impasse entre essas duas visões de sistema, já que a Cibernética era a ciência da regulação nas máquinas e nos seres vivos, conforme apregoado por Weiner, mas a própria Termodinâmica negava à teoria da informação o acesso à organização dos sistemas vivos.

Ironicamente, a Cibernética, como proposta de sistema, obteve mais sucesso em simular processos vitais do que a Teoria dos Sistemas Abertos, uma vez que esta disciplina se desenvolveu estudando o sistema nervoso e de como este perfazia e controlava laços de retroalimentação entre a intenção do movimento e sua execução efetiva. Ou seja, detinha-se no estudo da performance do sistema como um todo integrado. Essa performance foi pensada como um problema, fundamentalmente, de controle, de condução de uma mensagem num sistema para verificação dessa performance (por isso o nome Cibernética, do grego kybernetes, que significa piloto ou 
condutor). Essa simulação da performance do sistema nervoso servia bem tanto a uma analogia com a performance de uma intenção tanto na máquina quanto nos seres vivos, e não por outra razão que a equivalência entre computadores (ou sistemas cibernéticos em geral) e o sistema nervoso ou cérebro ganhou força em razão do sucesso dessa simulação. Essa equivalência se estendeu à noção de informação, como uma variável que teria a mesma natureza tanto na máquina quanto no sistema nervoso. Tal equivalência homem/máquina se tornou o "núcleo duro" da Cibernética, e fez com que propostas dos sistemas como abertos ou fechados fossem feitas à margem da Termodinâmica e da compreensão exposta na Teoria dos Sistemas Abertos.

[...] Ashby fala de um sistema como aberto ou fechado, dependendo de sua relação com a informação nova. Os sistemas fechados à informação nova, como o termostato, só são sensíveis a um nível do ambiente, no caso as diferenças de temperatura. Não tem capacidade de responder adaptativamente a outras variações do seu ambiente porque as relações de feedback possíveis são predeterminadas em sua estrutura. Antes de um sistema desses entrar em interação com o ambiente, o tipo de interação que terá com seu ambiente já está determinado. Alguns sistemas orgânicos também são citados como tendo essa sensibilidade restrita às variações do ambiente: o carrapato, por exemplo, seria sensível quase exclusivamente a certos compostos existentes no suor dos mamíferos. Nessa classificação, os sistemas abertos são aqueles abertos à informação nova, ou seja, sensíveis às variações no ambiente, sendo capazes de incorporar informação nova e, portanto, capazes de aprendizagem. Nesses sistemas, as relações possíveis vão se estabelecendo à medida que vai acontecendo a interação com o ambiente. (ESTEVES DE VASCONCELLOS, 2010, p. 208).

Porém, esse alargamento do conceito de informação para "informação nova", com o fim de incluir o comportamento complexo dos seres vivos na Cibernética, leva a um paradoxo: se uma variação no ambiente é instrutiva para o organismo a ponto de ser incorporada, então esta não se transforma em aprendizagem, porque o organismo reagirá a ela de novo se esta se repetir exatamente da mesma forma (apesar de mais elástica, a performance é igual à do termostato, que só demonstra feedback a variáveis predeterminadas); se o organismo reagir a uma variável independentemente das condições postas, então a variável, em si, não foi instrutiva, não havendo, portanto, uma incorporação (abertura), mas ainda assim criação de um comportamento novo (aprendizagem) terá sido demonstrada. Ou seja, o paradoxo indicaria que "informação nova" somente surge se proveniente das próprias operações do sistema, não sendo a variação em si (no ambiente) a informação, mas a "reação" do sistema, que é tratada 
como sendo a variável em si, isto é, uma diferença que pode ser usada pelo sistema em qualquer contexto de acordo com suas necessidades adaptativas. O paradoxo colocaria em xeque tanto a noção de informação como uma instrução que é estimada como uma grandeza segundo uma distribuição probabilística num canal de comunicação (Teoria Comunicacional da Informação), quanto a noção de que um sistema precisa ser "aberto à informação" para tê-la.

A noção de "informação nova", portanto, não poderia ser entendida dentro dos parâmetros tradicionais de tratamento da informação, e isso foi percebido inclusive por ciberneticistas que começaram a construir uma nova compreensão da relação entre sistema e informação. Essa nova compreensão surgiu dos próprios estudos da Cibernética sobre o circuito da informação no fenômeno de feedback (retroalimentação). A retroalimentação, sendo nada mais que um mecanismo de retroação que vai dizendo ao sistema como este vai funcionando, tinha que ser entendida em seu modo de operação para que mecanismos autorregulados pudessem ser construídos. A autorregulação compreendia tanto a manutenção do estado do sistema quanto a direção deste para a meta. O primeiro modo que a Cibernética considerou como operação da manutenção da autorregulação foi aquele baseado na informação proveniente de uma perturbação ou desvio já presente, que se destinava a operar como um regulador de circuito fechado (servomecanismo controlado pelo erro), e por esse motivo:

Esse tipo de retroalimentação, em que a informação sobre o erro - ou sobre o desvio do output em relação ao alcance da meta atua no sentido de diminuir ou reduzir o desvio, é chamado de retroalimentação negativa ou feedback negativo. Importante ter claro que o adjetivo negativo se refere ao efeito de reduzir a amplitude do desvio [...]. (ESTEVES DE VASCONCELLOS, 2010, p. 208).

Tal tipo de feedback (retroalimentação) é um mecanismo homeostático por manter o sistema em um estado constante, trazendo-o de volta para o equilíbrio quando este é perturbado.

O outro tipo de retroalimentação vai na contramão: a reintrodução da informação no sistema acentua um desvio existente no output em relação a uma tendência prévia que caracterizava esse sistema, portanto, trata-se de uma retroalimentação positiva, no sentido que aumenta o desvio, e também de autorreforço por intensificar os efeitos do processo: 
do sistema: ou produz ruptura do sistema, se os parâmetros deste não comportarem desvios tão grandes; ou produz mudanças qualitativas em seu funcionamento, se suas características comportarem uma evolução ou um salto descontínuo ou uma mudança qualitativa para novas formas de funcionamento. Nesses casos, costuma-se dizer que esse tipo de feedback é um mecanismo morfogenético (morfo=forma), ou seja, um mecanismo que produz a gênese ou surgimento de formas novas de funcionamento. (ESTEVES DE VASCONCELLOS, 2010, p. 223-224).

Podemos constatar nesse segundo tipo de retroalimentação um mecanismo mais compatível com a descrição de um sistema vivo, no qual a informação participa não mais como instrução, mas como obrigação à seleção de uma nova forma ou regra, sob pena de autodestruição. Essa seleção pode seguir dois caminhos: o contingenciamento por uma sub-rotina de feedback negativo que leve o sistema de volta senão à meta original a um simulacro dessa meta, ou pela criação de uma nova forma ou regra que leva o sistema a um novo patamar ou contexto. No primeiro caso, podemos invocar a própria natureza e seus processos de equilíbrio ecológico, no segundo, teríamos um fenômeno muito mais complexo, como a transformação de barbatanas em membros para andar na terra, ou uma regra social que passa a ser considerada nociva por uma sociedade e é substituída por outra completamente diferente. Mas de qualquer forma, como notou Esteves de Vasconcellos (2010, p. 225), a Cibernética valorizou muito mais os efeitos corretivos do feedback negativo e não deu atenção aos efeitos desintegradores ou transformadores do feedback positivo. Os motivos para isso são tanto prosaicos quanto profundos. $\mathrm{O}$ motivo mais simples era que só classificamos um processo de retroalimentação como positivo ou negativo a posteriori e, sendo os processos de feedback negativo mais previsíveis porque uma meta pode ser traçada previamente, eram também mais fáceis de simular em mecanismos cibernéticos. A questão mais profunda, porém, era que a teoria da informação foi criada para impedir desvios (garantir a comunicação da informação) e não fornecia, portanto, instrumentos matemáticos adequados para lidar com a criação de novas formas ou regras.

É preciso parar para analisar cuidadosamente a questão da práxis da construção conceitual de informação para não cairmos num dualismo. A conhecida afirmação de Weiner de que "informação é uma medida de organização", pelo caráter amplamente abstrato que ganhou, acabou obliterando a fisicalidade que originou boa parte da articulação conceitual de Shannon e Weaver, começando pelo fato do cálculo probabilístico da informação ser o mesmo do cálculo da entropia num sistema, como 
apontado por Bertalanffy. Esse fato não é estranho se lembrarmos que Shannon, como engenheiro, estava preocupado principalmente em evitar a degradação de um sinal num canal de comunicação. Esse fato é central porque sua teoria da informação é basicamente a observação da organização de um sinal, as possibilidades de organização desse sinal (as possibilidades de articular o código), e as possibilidades de transmitir esse código (que é, em suma, a replicação de uma dada organização num suporte material). Essa observação nada mais fez que verificar quais as possibilidades que esse sistema oferecia de organização, e a teoria foi pautada nessas possibilidades. Se o sistema era fechado, como o é qualquer sistema em equilíbrio físico como uma pedra ou uma máquina, qualquer medida de organização teria que levar em consideração sua possível degradação ("ruído"). Se esse sistema possui como nível mínimo de articulação estrutural (a sua replicação de uma estrutura para outra) uma seleção dual, então o código será dual (sim/não ou $0 / 1$ bits). Portanto, quando dizemos que informação "é uma medida de organização" deveríamos perguntar "onde é essa medida de organização?", que é uma pergunta a ser feita pelo observador, por quem está observando o sistema, como preconiza Maturana (1999), para sabermos que sistema estamos observando e se o modo como este se constitui permite essa medida.

Sem essa pergunta, generalizamos uma medida de informação independente das possibilidades de organização que cada sistema permite, abstraindo seus métodos de suas possibilidades estruturais de realização, como nas tentativas infrutíferas de calcular “a quantidade de informação" em textos literários ${ }^{29}$ ou outros tipos de mensagens nas mídias. Sem essa pergunta, outra generalização ocorre, mas em sentido inverso: em vez da informação abstraída do sistema e tornada medida universal, a informação é tornada intrínseca à organização do sistema e qualquer diferença entre estes acaba sendo "nivelada" para que a informação "flua" de um sistema para outro, desconsiderando igualmente as diferenças como na perspectiva abstracionista. A segunda generalização é expressa mais frequentemente no senso-comum, mas também funciona como uma noção implícita de informação em trabalhos científicos e filosóficos, como nesta argumentação do filósofo Zeman:

A informação, que está ligada à organização, está ligada

\footnotetext{
29 "Para a Teoria da Comunicação, que tenha seres humanos como pólos comunicacionais, a Teoria da Informação só tem sentido se for contextualizada, se seus conceitos servirem como elemento a mais na análise de mensagens. Quantificar mensagens, isoladamente, não tem sentido e nem é esse o objeto da Teoria da Informação.” (RESENDE; FERNANDES JÚNIOR, 1988, p. 66).
} 
também à conservação e transmissão desta organização. [...] O sinal recebido pelo receptor dos sentidos transforma-se em forma fisiológica da informação conservada na memória, tornando-se assim uma parte da experiência individual e podendo influenciar igualmente a experiência genética, a hereditariedade (influência do reflexo do meio sobre o organismo). Deste modo, como base no processo do reflexo, a natureza se imprime cada vez mais profundamente no organismo [...]. (ZEMAN, 1970, p.159).

A segunda generalização tem também larga disseminação na noção da informação como coisa (BUCKLAND, 1991), de informação como "algo que afeta a mente" ou como "fluxo informacional" "30, elaborações estas que são objeto de crítica por causa de sua superficialidade não apenas na Ciência da Informação como em outros campos científicos:

Alguns teóricos desafiam a noção, algumas vezes implícitas, mas mais frequentemente explícitas na maioria das abordagens contemporâneas da aprendizagem social, que a aprendizagem social ocorre através da "transferência" de "informação" de um indivíduo a outro. Informação, afinal de contas, não é uma coisa. A aprendizagem não requer a transferência de partículas de informação, inalteradas durante a transferência pelo do espaço entre as cabeças. ${ }^{31}$ (FRAGASZY; PERRY, 2003, p. 14, grifos nossos).

Essas duas generalizações são o lado A e o lado B de uma análise dualista, o "núcleo duro" da abordagem objetivista do mundo. A dicotomia objetivista é mais profunda do que simplesmente colocar a ênfase do processo de conhecimento no objeto. $\mathrm{Na}$ verdade, ela interdita o processo do conhecimento ao interditar a ontogênese do conhecer do objeto: este sempre está pré-dado, seja como informação "transcendente" ao sistema, seja como informação "imanente" ao sistema. Melhor dizendo, ou a informação transcende todos os sistemas como uma medida abstrata objetiva dos sistemas, ou a informação é imanente aos sistemas, isto é, uma propriedade emergente destes que os configura independentemente do entorno (as propriedades subjetivas dos sistemas). O uso destes termos metafísicos tem um propósito: frisar que a noção de informação permanece na visão objetivista (e clássica) como uma operação deslocada das operações próprias do sistema, como uma operação abstrata objetiva ou como uma

\footnotetext{
${ }^{30}$ É esta larga aceitação da informação como imanente à organização das coisas que sustenta a variação cognitivista da representação como uma transferência da organização dos objetos do mundo para uma versão em escala mental deste (sua redução).

${ }^{31}$ Some theorists challenge the notion, sometimes implicit but more often explicit in most contemporary treatments of social learning, that social learning occurs through the "transfer" of "information" from one individual to another. Information, after all, is not a thing. Learning does not entail the transfer of particles of information, unchanged during transfer across the space between heads. (FRAGASZY; PERRY, 2003, p. 14).
} 
operação concreta subjetiva, permanecendo assim generalistas e desvinculadas da ontogênese dos sistemas.

Portanto, superar a visão objetivista da informação é superar a visão subjetivista criando um vínculo entre informação e sistema através da observação das operações deste, e observação pressupõe um observador dizendo qual é a diferença que constitui um sistema X como diferente do seu meio. Recupera-se aqui o sentido original de informação (informatio) como "dar forma a algo", mas no sentido de um observador distinguindo, dando forma à forma, e trazendo assim um sistema à observação (ao contrário do conceito agostiniano de uma forma derivada da impressão causada pelas coisas). Um sistema seria então, em primeiro lugar, a observação da operação de uma diferença em relação a seu meio:

O que muda na atual compreensão da Teoria dos Sistemas, em relação aos avanços alcançados nos anos 1950 e 1960, é uma formulação mais radical, na medida em que se define o sistema como a diferença entre sistema e meio. Tal formulação necessita de um desenvolvimento explicativo, já que se apóia em um paradoxo de base: o sistema é a diferença resultante da diferença entre sistema e meio. O conceito de sistema aparece, na definição, duplicado no conceito de diferença. (LUHMANN, 2009, p. 81).

Informação deixa de ser algo separado ou subjacente ao sistema, mas se constitui como possibilidade de engendrar mais diferenças neste (ou seja, passamos aqui para uma noção constitutiva de informação).

Em campos paralelos, como no da informação, a teoria atual, entendida como teoria da diferença, extrai seus fundamentos da formulação clássica de Gregory Bateson: a informação é a difference that makes a difference. Portanto, a informação é uma diferença que leva a mudar o próprio sistema; tão somente pelo fato de ocorrer, transforma [...]. Essa teoria da informação emerge de uma base apoiada na diferença, e pousa em um campo de diferenças. Todo o acontecimento do processamento da informação fica sustentado por uma diferença e se orienta precisamente para ela. É a diferença que engendra a informação posterior. (LUHMANN, 2009, p. 84).

O que há de radical nessa abordagem é que se ultrapassa completamente o paradigma representacionista ${ }^{32}$, ao estabelecer que a informação deixe de ser a

\footnotetext{
32 Englobamos neste paradigma o que Capurro denomina de "paradigma físico" e "paradigma cognitivo", mas apenas quanto ao que se assume como sendo a natureza da informação nestes paradigmas (localista ou fragmentada entre os indivíduos, respectivamente), sem constituir um juízo de valor sobre os programas de pesquisa desenvolvidos sob esses paradigmas.
} 
representação ou o transporte informacional de algo, através da operação de separação entre objeto e sujeito (ou como na separação sistema/observador), para ser a própria operação que constitui o observador, isto é, a observação. Assim, uma teoria dos sistemas é uma teoria do observador, onde "observar é a operação, enquanto observador é um sistema que utiliza as operações de observação de maneira recursiva, como sequências para obter uma diferença em relação ao meio" (LUHMANN, 2009, p. 154). Essa nova teoria dos sistemas difere daquela de Bertalanffy, baseada no equilíbrio e na objetividade independente dos sistemas, e da Primeira Cibernética (Weiner), baseada na busca da metaestabilidade e na previsibilidade do processo de retroalimentação, mas se aproxima (e aproveita) as conquistas teóricas da Segunda Cibernética (Heinz von Foerster) que explorou os processos de retroalimentação positiva (a diferença como informação) e destacou que nenhum sistema pode ser observado sem ser afetado pela observação:

Como a mecânica quântica nos ensinou, observador e observado não podem ser separados, e o resultado das observações dependerão de sua interação. O observador é também é um Sistema cibernético, tentando construir um modelo de outro sistema cibernético. Para entender este processo, precisamos de uma "cibernética da cibernética", i.e. uma "meta" cibernética ou uma cibernética de "segunda ordem". ${ }^{33}$ (HEYLIGHEN e JOSLIN, 2001, p. $4)$.

Luhmann faz uso, principalmente, da noção de que todo sistema apenas é sistema enquanto em interação com outro sistema, portanto, todo observador é também um sistema que participa daquilo que observa como sistema. Isto implica que a noção de observador não tem a ver com a de consciência, nem muito menos com a (noção clássica) de sujeito $^{34}$ :

O observador é um sistema, e um sistema pode ter uma capacidade de localização flexível: o sistema pode observar a si mesmo (auto-observação), e também outros sistemas (heteroobservação). Para a teoria do sujeito, em contrapartida, é muito difícil argumentar sob o emprego teórico da diferença. O sujeito sempre deve

\footnotetext{
${ }^{33}$ As quantum mechanics has taught us, observer and observed cannot be separated, and the result of observations will depend on their interaction. The observer too is cybernetic system, trying to construct a model of another cybernetic system. To understand this process, we need a "cybernetics of cybernetics", i.e. a "meta" or "second-order" cybernetics. (HEYLIGHEN; JOSLIN, 2001, p. 4).

${ }^{34}$ Luhmann destaca aqui apenas a noção de sujeito como formulada na filosofia, na concepção clássica da separação sujeito/objeto. Existem teorias contemporâneas do discurso, e também nas teorias da comunicação (Barbero e Canclini, por exemplo), nas quais a noção clássica de sujeito é substituída pela de sujeito social, de características não-transcedentais, participante do mundo e da construção dos objetos observado.
} 
estar colocado em um lugar (transcendental) acima dos objetos do mundo. Seria muito difícil encontrar no conjunto da tradição de pensamento a resposta para a pergunta sobre onde está o sujeito, se no sistema, ou no meio. (LUHMANN, 2009, p. 163).

O sistema observador é qualquer sistema, nessa nova teoria dos sistemas, que ao realizar uma diferença em relação ao meio o faz na interação com outro sistema, e que com essa diferença diga ao sistema o que o separa daquele sistema, ou seja, que o informe sobre o que é o outro sistema. Desta maneira, um sistema observante pode ser de outra ordem, não necessariamente um indivíduo; por exemplo, um sistema social, que ao diferenciar o que se pode ou não fazer num determinado contexto (uma regra social), observa outros sistemas (indivíduos), os quais, por sua vez, ao se diferenciarem entre si mesmos e um sistema social podem observar este último.

Nesta imbricação entre sistema/observação é que reside a abordagem sistêmica da informação: informação é a possibilidade latente de um sistema de autodiferenciar-se em relação a um meio (auto-observação) ou em relação a um sistema (heteroobservação). Diferenciar-se é uma operação do sistema de conseguir informação (organizar-se ou organizar um outro), portanto, a avaliação da informação é a avaliação dessa operação no sistema e a avaliação da conexão dessa operação com outros sistemas. Assim, informação é, grosso modo, a possibilidade de um sistema selecionar (em si mesmo ou em outros sistemas) diferenças (reorganizar-se). Nessa nova teoria dos sistemas, a organização não precede a informação, mas se articula concomitantemente a esta; e no momento em que a seleção termina e temos uma organização, não temos mais informação, assim, seria errôneo falar em "fluxo da informação". A sensação de fluxo é construída porque sempre há uma obrigação latente à seleção entre sistemas diferentes que mantém um acoplamento recursivo. O estudo de como os sistemas se organizam é então fundamental para entendermos como estes realizam a informação (sua própria possibilidade de organização). Nesta nova teoria dos sistemas, portanto, o tema da organização e o tema da informação não apenas andam juntos como estão imbricados.

Analisando a organização dos sistemas a partir da informação, podemos ao mesmo tempo caracterizar os sistemas (como organizações abertas ou fechadas) e identificar como estes realizam informação (como estruturas abertas ou fechadas). Esta distinção não era realizada antes na Teoria dos Sistemas: ou o sistema era fechado ao ambiente ou era aberto, e a conceituação a respeito não era clara quanto aos sistemas vivos como abertos (se apenas estes eram exclusivamente abertos), bem como e quando 
eram abertos ou não à informação (ESTEVES DE VASCONCELLOS, 2010). Foi Maturana quem realizou esta distinção ao argumentar que quaisquer fenômenos devem ser considerados, sobretudo, enquanto estruturas que se configuram para permitir uma organização:

Entende-se por organização as relações que devem ocorrer entre os componentes de algo, para que seja possível reconhecê-lo como membro de uma classe específica. Entende-se por estrutura de algo os componentes e relações que constituem concretamente uma unidade particular e configuram sua organização. (MATURANA ROMESÍN; VARELA GARCÍA, 2002, p. 54).

Maturana raramente se refere em suas obras ao termo informação, principalmente porque nas ciências era generalizada a noção de informação como instrução (SHANNON e WEAVER), e a instrução seria uma categoria limitada para descrever os sistemas vivos. Mas na crítica dessa limitação é que encontramos a explicação de como se realiza a informação: sendo a informação instrutiva uma transferência de organização (uma configuração de relações), os componentes (a estrutura) do sistema devem ser capazes de replicar essa configuração de relações. $\mathrm{Ou}$ seja, o limite está em que a organização deve ser aberta (passiva de instrução) e a estrutura deve ser estável (fechada ao ambiente, para não perturbar essa estabilidade estrutural) para permitir essa transferência de organização via manipulação das relações estruturais. Um sistema (limitado) surge então aí através das possibilidades de realização estrutural da informação: aberto para permitir a transferência da instrução, mas fechado para permitir a estabilidade dessa transferência (como sua possível repetição), tornando-o não aberto às complexidades do ambiente e dependente da importação de organização para exibir complexidade.

Assim, podemos entender a ligação umbilical entre informação e sistema: temos um sistema através das possibilidades estruturais de organização, e informação através das possibilidades organizacionais de um sistema. Definimos a informação, portanto, através das características de organização de um sistema, e o sistema através da operação de informação permitida pela articulação estrutural desse sistema. Se caracterizarmos um sistema como uma organização aberta a mudanças de estado nessa organização, então definimos a informação nesse sistema como instrutiva; se definimos que podemos operar na estrutura a ponto de mudar sua organização (passar instruções) então poderemos caracterizar esse sistema como organizacionalmente aberto. Este não é um raciocínio circular, mas a imposição de uma condição dupla: só podemos 
caracterizar um sistema (definir sua organização como aberta ou fechada) definindo neste qual a operação de informação (a mudança nessa organização) que sua estrutura permite. O critério básico a ser analisado é o da susceptibilidade dessa estrutura às mudanças: organização aberta se a estrutura for estável o suficiente para permitir predizer essas mudanças, ou fechada se a estrutura for tão dinâmica que as mudanças se tornam imprevisíveis - e, portanto, sua organização fica fechada à observação ${ }^{35}$. É preciso observar que um critério é condição do outro: um sistema não pode ser aberto (à informação) se a estrutura for dinâmica, e o sistema em si não pode ser dinâmico a menos que seja fechado à informação (ser aberto à informação requer estados estáveis, de recepção da informação). Seguindo este raciocínio, Maturana argumenta que a informação instrutiva em sistemas vivos é uma impossibilidade uma vez que estes são estruturalmente determinados (fechados em sua dinâmica estrutural):

Estamos habituados a falar da "informação" contida numa imagem, num objeto ou, de modo mais evidente, na palavra impressa. Segundo nossas análises, essa metáfora é fundamentalmente falsa, porque supõe a existência de uma unidade não estruturalmente determinada na qual as interações são instrutivas - como se aquilo que acontece a um sistema, durante uma interação, fosse determinado pelo agente perturbador e não pela dinâmica estrutural desse sistema. (MATURANA ROMESÍN; VARELA GARCÍA, 2002, p. 218).

Continuando o raciocínio de Maturana, se a estrutura dos seres vivos é dinâmica e permanentemente mutável, então não permite a abertura à informação instrutiva, mas por outro lado essa estrutura está aberta à complexidade do meio justamente porque é dinâmica o suficiente para organizar um fluxo de formas novas para lidar com essa complexidade. Ou seja, enquanto sistemas estruturalmente imutáveis (não-dinâmicos, não-vivos) estão abertos à importação de organização (informação), mas se fecham ao ambiente, sistemas estruturalmente mutáveis (dinâmicos, vivos) podem criar sua própria organização e assim serem abertos ao ambiente. Ser aberto ou ser fechado para um sistema significa, nessa teoria dos sistemas, ser aberto à informação (a uma forma de organização, isto é, "ser informado") ou ser fechado à informação (criar sua própria forma, isto é, "informar"). Assim, a condição para um sistema estar aberto ao ambiente é a capacidade de reduzir a complexidade deste a uma forma que lhe convém, e se não consegue cumprir esta condição então precisa ser fechado ao ambiente para continuar

\footnotetext{
${ }^{35} \mathrm{Na}$ teoria de Bertalanffy um sistema dinâmico seria aberto, mas nessa teoria a concepção de organização se volta para a incorporação de materia e energia, a informação não aparece formalmente inserida nessa incorporação.
} 
como sistema organizado. Estas não são apenas, como se vê, descrições dos sistemas, mas suas próprias condições de existência. Um computador $^{36}$ (sistema aberto à informação) que estivesse aberto a qualquer variância elétrica do ambiente não poderia organizar seu código binário adequadamente, e pararia de funcionar. Se os seres vivos (sistemas fechados à informação) fossem organizados desde fora pela complexidade do ambiente seriam pautados por essa complexidade, não existiriam formas diferentes de adaptação, apenas um reflexo da totalidade dessa complexidade - ou seja, algo que é o oposto do que é observado na natureza (para cada nicho ecológico, por exemplo, existiria apenas um tipo de forma de vida). Pelo contrário, os seres vivos não só não são um reflexo da complexidade, como contribuem para aumentá-la ao, ironicamente, tentar reduzi-la a uma forma adaptada a essa complexidade, porque acrescentam novas formas ao ambiente e consequentemente novas possibilidades de relações constitutivas (de fato, sem esse processo, provavelmente o que chamamos de nicho ecológico não existiria).

O paradoxo a ser explicado é que os seres vivos, por serem fechados à informação, são capazes de criá-la. Esse paradoxo torna-se insuperável quando se busca algum tipo de fundamentação externa para a gênese informacional dos sistemas vivos. Na verdade, só se torna superável quando buscamos a explicação no próprio paradoxo: na constituição recursiva da estrutura viva. Como notou Prigogine (PRIGOGINE; STENGERS, 1992), os sistemas vivos só chegam a se constituir como tal por serem a manutenção de uma diferença na possibilidade organizacional de um sistema, ou seja, um sistema longe do equilíbrio. O sistema vivo surge como uma dinâmica de diferenças estruturais, que procuram manter, sempre, uma desigualdade que impõe uma forma (uma organização). Sem a manutenção dessa desigualdade a forma organizacional se rompe. Cada possibilidade organizacional num sistema vivo é a inserção de uma nova diferença na desigualdade (o equilíbrio como meta, nunca como ponto final). Tudo que está vivo é, operacionalmente, a escolha de uma assimetria. Para Maturana (2002), a vida em si é cognição, porque o que constitui o sistema vivo é uma escolha que resulta numa forma, que por sua vez é uma escolha de interação com o ambiente, que por sua vez é uma escolha de conhecer o mundo. Damásio lidou recentemente com a questão do surgimento da cognição e defende que esta se manifesta nos níveis mais básicos:

\footnotetext{
36 Tal como conhecemos os computadores atuais, como sistemas eles também poderiam ser estruturalmente determinados (organizacionalmente fechados) se forem estruturalmente dinâmicos o suficiente para tratar recursivamente as estruturas criadas como resposta a um "input".
} 
Desprovido de conhecimento consciente, sem acesso aos intrincados mecanismos de deliberação disponíveis ao nosso cérebro, o organismo unicelular parece ter uma atitude: quer viver tanto quanto sua dotação genética lhe permite. Por mais que nos cause estranheza, esse ímpeto, com tudo que é necessário para implementá-lo, precede o conhecimento explícito e a deliberação sobre as condições de vida, uma vez que o organismo claramente não os possui. $\mathrm{O}$ núcleo e $\mathrm{o}$ citoplasma interagem e executam complexas computações voltadas para a manutenção da vida da célula. Lidam com os problemas que as condições da vida lhes impõe a cada momento e adaptam a célula às situações de modo que ela consiga sobreviver. Dependendo das condições do ambiente, rearranjam a posição e a distribuição das moléculas em seu interior e mudam a forma de seus subcomponentes, como os microtúbulos, numa espantosa demonstração de precisão [...]. (DAMÁSIO, 2011, p. 53).

Esse ímpeto descrito por Damásio é, para Maturana (2002), a própria operação da estrutura viva que, assim produzida - e reproduzida - a partir de seus próprios componentes, está sendo autoproduzida (autopoiese), porque a operação de organização da estrutura parte da própria estrutura. Desta forma, informação não pode ser considerada como um elemento neutro independente do sistema, ou como elementos isolados dentro deste (como a noção de informação genética ${ }^{37}$ ), mas como uma possibilidade de seleção da organização de um sistema de acordo com sua estrutura (as opções de operação permitidas pela estrutura). A natureza informacional dos seres vivos pode ser identificada, portanto, nessas possibilidades de seleção de organização, a partir da complexidade estrutural que estes dispõem para si próprios.

Mas, assim como os seres vivos oferecem ao seu meio novas complexidades através de novas possibilidades de relações estruturais constitutivas, estes também se tornam mais complexos através do mesmo processo, isto é, disponibilizando novas estruturas complexas a partir das quais novos fenômenos biológicos podem emergir. A vida seria, assim, um processo de oferecer novas possibilidades de seleção através das quais as operações de seleção (a informação) constituem novas ordens e, portanto, novos sistemas. Tal processo não corresponde, como apontou Luhmann (2009) em relação a certas interpretações da teoria dos sistemas, à busca de um processo integrador na unidade, holisticamente considerado, mas à busca dos sistemas vivos por flexibilidade e plasticidade na adaptação ao meio. Luhmann, citando Ashby (LUHMANN, 2009, p. 181), afirma que "um sistema que pode dispor de níveis de

37 "É a totalidade da rede de interações que constitui e especifica as características de uma determinada célula, e não um de seus componentes. [...] O erro está em confundir participação essencial [dos genes] com responsabilidade única." (MATURANA ROMESÍN; VARELA GARCÍA, 2002, p. 81). 
gradação é um sistema que pode ser designado como ultraestável" (que é o que almeja um sistema multicelular de complexidade crescente). Segundo aponta Luhmann, a vantagem para esse tipo de sistema é que

[...] os transtornos que o sistema experimenta, provenientes do meio, não têm de ser enfrentados como um todo, mas podem ser selecionados e enfrentados localmente: a dor de estômago, que se concentra no ventre, e não é necessariamente uma dor completa do corpo; ou as dificuldades econômicas que um sistema social experimenta, mas que nem por isso transformam-se automaticamente em dificuldades políticas [...]. (LUHMANN, 2009, p. 181).

Para Luhmann, o importante dessa descoberta é que a mudança só ocorre na medida em que o sistema pode delimitar divisões, e isto implicaria em uma ruptura com o modo de pensar holístico, para o qual, para mudar, o sistema teria que necessariamente mobilizar todas suas partes e interdependências simultaneamente:

Os aspectos negativos do modo de pensar holístico se fizeram patentes quando se compreendeu que a perfeição não é um estado intrínseco de aspiração do sistema. Pelo contrário, a perfeição é um preceito improvável, já que suporia que a qualquer perturbação externa o sistema teria de responder de maneira sincronizada, o que implicaria uma enorme necessidade de tempo para poder reagir à perturbação subsequente. (LUHMANN, 2009, p. 181).

Assim como nos sistemas vivos, a informação seria a introdução de uma assimetria na forma (uma escolha que leva à organização dessa forma), a transformação dessa forma (organização) é igualmente garantida por uma assimetria (gradação) através de uma mudança no tipo de seleção realizada pelo sistema (escalonamento da informação). Isto tem uma implicação importante no modo como consideramos a emergência de sistemas novos. Estes não surgiriam como totalidades integradas num continuum, mesmo em organismos tidos como unidades complexas como o corpo humano, mas como sistemas acoplados de modo amplo (loose coupling), isto é, cada qual surgindo e realizando sua própria autopoiese (através da operação de seleção que o constitui). Disto retiramos uma compreensão de informação na qual esta

[...] não é a exteriorização de uma unidade, mas sim a seleção de uma diferença que leva a que o sistema mude de estado e, consequentemente, opere-se nele outra diferença. Tudo isso leva à consideração de que a informação só é possível no sistema. Cada sistema produz sua informação, já que cada um constrói suas próprias expectativas e esquemas de ordenação. (LUHMANN, 2009, p. 141). 
Estas considerações levam a uma reformulação do conceito de sistema, como proposto correntemente ${ }^{38}$, a qual coloca uma ênfase nos elementos que perfazem um sistema, em vez de focar no tipo de relação que se constitui entre esses elementos. Para Luhmann, isto é um erro por dois motivos: a) ao analisarmos quais elementos possui um sistema, podemos encontrar tipos de elementos comuns a dois sistemas e, assim, acharmos que eles possuem uma natureza em comum, quando, na verdade, podem ser radicalmente distintos; b) tal ênfase nos elementos do sistema tira a atenção sobre a relação entre estes, que é, na verdade, o que vem a constituir o sistema, isto é, a relação entre os próprios processos de construção de relações como reforços mútuos que vêm a constituir um tipo de operação específica que demarca uma diferença entre o meio e esta operação (um sistema - a sua definição, na verdade - é, então, esta demarcação como uma diferença meio/sistema). Para Luhmann, portanto, distinguir entre tipos de sistemas significa assinalar o tipo de operação que o constitui:

[...] Demanda-se pelo critério que viabiliza a emergência; isto é, a diferença constitutiva pela qual um sistema se separa mediante sua respectiva operação de outros níveis de realidade. (LUHMANN, 2009, p. 263).

Não realizar essa distinção, inclusive, teria como impacto negativo não reconhecermos, na evolução do vivo, o aparecimento de novos fenômenos como sistemas emergentes. $\mathrm{O}$ critério que viabiliza a emergência é o mesmo que nos permite definir informação e sistema um em relação ao outro e de contemplar um conceito escalar de informação: a produção de uma diferença que viabiliza uma forma de operar a seleção constitutiva de um sistema, mas daquele sistema e de nenhum outro. Ou seja, a emergência de uma nova forma de operar uma seleção (realizar informação) faz surgir um novo sistema (uma nova forma de diferenciar um sistema do meio) e esse sistema subsiste apenas enquanto essa operação for possível e sua forma de organizar o sistema não for perturbada. Isso significa que sistemas não compartilham a mesma operação. Se o fizessem haveria apenas dois resultados: ou seriam o mesmo sistema ou haveria uma aniquilação recíproca dos sistemas.

Por isso, na teoria dos sistemas autopoiéticos existe o conceito de encerramento operativo, pelo qual o sistema e tão somente o sistema opera a seleção de sua própria organização, mas justamente por ser operacionalmente fechado que esse tipo de sistema

\footnotetext{
${ }^{38}$ Mais precisamente nas formulações reducionistas, geralmente importações inadequadas do conceito de sistema de Bertalanffy para outras áreas.
} 
pode entrar em acoplamento estrutural (a contínua adaptação da estrutura do sistema à interação com o meio - que pode ser outro sistema) ${ }^{39}$, uma vez que o encerramento seleciona as estruturas de interação assim selecionando um modo de interação (um modo de conhecer). Baseado em pesquisas neurofisiológicas, Luhmann dá o exemplo do cérebro:

[...] O acoplamento que o cérebro realiza com o meio ambiente ocorre através dos sentidos da visão e dos ouvidos, os quais, por sua vez, têm possibilidades muito reduzidas de contato com o meio (estreita gama de cores, para a visão; cota de decibéis, para os ouvidos). Graças a essa especificação, o sistema não está sobrecarregado pelo exterior, e pode processar efeitos que levam ao surgimento de estruturas complexas no cérebro. Portanto, a um espectro reduzido para fora corresponde uma enorme criação de estrutura para dentro: elevada capacidade de avaliação, a partir da seleção da própria irritabilidade de que o sistema dispõe. (LUHMANN, 2009, p. 132-133).

A complexidade dos seres, a sua evolução, surge então do acoplamento estrutural: cada vez que estes reduzem a complexidade do meio realizam uma seleção que resulta em estruturas mais complexas do que as estruturas selecionadas para interagir com meio, o que, por sua vez, abre o leque de seleções possíveis permitidas por estas novas estruturas. A evolução do conhecer, portanto, não depende dos dados do exterior, mas da congruência na coevolução dos sistemas de seleção. Cada vez que um novo sistema surge como uma operação de seleção estruturalmente diferenciada, este precisa da complexidade disponibilizada pelo seu contexto de surgimento. Contudo, não há, na visão de Luhmann, interpenetração entre as diferentes operações de seleção (transferência de informação entre os sistemas), haveria apenas interpenetração entre as diversas ordens de complexidade disponibilizadas mutuamente através do acoplamento estrutural mesmo quando, na ordem dos seres vivos, os sistemas se acoplam para formar uma unidade, como no caso de um ser humano. Esta observação se torna particularmente interessante para a sociologia (e nós acrescentaríamos, para a Ciência da Informação), segundo Luhmann, quando passamos a considerar nessa reflexão os sistemas de sentido (os sistemas que situam a diferença entre indivíduo e sociedade):

[...] O importante no campo da sociologia seria a possibilidade de fazer reflexões equivalentes, no sentido de se indagar como a comunicação e a consciência se acoplam estruturalmente, já que se

\footnotetext{
${ }^{39} \mathrm{O}$ conceito de acoplamento estrutural não deve ser entendido, de forma alguma, como algo mecânico (semelhante a um mecanismo com engrenagens), mas como uma deriva (algo não dirigido) entre estruturas.
} 
trata, na realidade, de dois sistemas autopoiéticos ${ }^{40}$. O processo de resposta deve levar em conta, primeiramente, que consciência e comunicação não podem existir uma sem a outra, e que, para existir, devem estar coordenadas mediante um acoplamento estrutural. (LUHMANN, 2009, p. 133).

Os sistemas de sentido, a consciência e a comunicação (sistemas sociais), deveriam ser analisados então desde a operação que os constitui (a operação que permite o processamento de informação em cada um), respeitando o acoplamento estrutural que fornece os subsídios para a mudança estrutural em cada um e, portanto, que fornece o contexto para a coevolução de ambos. Nas palavras de Luhmann:

Não é possível imaginar que a consciência tivesse surgido no processo da evolução sem ter havido comunicação; assim como também seria impossível que pudesse haver comunicação de conteúdos significativos sem ter havido consciência. Nesse sentido, toda comunicação está estruturalmente acoplada à consciência; sem consciência, a comunicação é impossível. Entretanto, a consciência não é um sujeito da comunicação, tampouco, em qualquer outro sentido, o substrato da comunicação. Para tanto, devemos abandonar a metáfora clássica, segundo a qual a comunicação é uma espécie de transferência de conteúdos semânticos de um sistema psíquico - que já os possui - a outros. (LUHMANN, 2009, p. 133).

A partir dessa visão, definiremos a abordagem sistêmica da informação como a consideração da natureza escalar da informação (a informação como possibilidades de seleção que levam o observador à configuração de uma realidade fenomênica), a qual acontece no marco de um sistema que demarca suas possibilidades de realização. A preocupação deste trabalho, em relação a essa abordagem, será especificar a natureza dessa escala dentro dos sistemas de produção de sentido (sistemas psíquicos e sociais), a partir dos quais a Ciência da Informação realiza suas inferências sobre a natureza do seu campo de estudo. Especificamente, trabalharemos, nos capítulos seguintes, na questão

\footnotetext{
${ }^{40}$ Existe uma polêmica quanto a denominar sistemas de comunicação de autopoiéticos, uma vez que se fossem sistemas autopoiéticos de primeira ordem (que autoproduzem sua organização), como observa Maturana, ficariam excluídos da fenomenologia humana por incompatibilidade (MATURANA ROMESÍN; VARELA GARCÍA, 2004). Acreditamos que de fato não se pode denominar um sistema social ou comunicacional de autopoiéticos pela razão acima, e sim que os fenômenos sociais e a comunicação são autopoiéticos por continuidade, isto é, que toda descrição desses dois fenômenos deve levar em consideração que os seres humanos são unidades autopoéticas. Por outro lado, devemos registrar que talvez exista um mal-entendido nessa polêmica uma vez que nas exposições de Luhmann em aula (LUHMANN, 2009), fica mais claro que esses sistemas são fruto da observação e que não possuem uma dinâmica independente (portanto, não são sistemas de primeira ordem). De fato, essa abordagem não aparece em suas obras mais formais (LUHMANN, 1990), o que pode ter gerado a polêmica. Nossa leitura de Luhmann segue essa abordagem, e só destacamos o social enquanto sistema porque entendemos que a realização da informação (as diferenças que o observador distingue) ganham uma outra dinâmica quando coordenadas socialmente (nas inter-relações entre as escalas de tempo e interação individual e coletiva).
} 
da informação como seleção de consciência (nos sistemas psíquicos) e seleção de sentido (nos sistemas sociais), desde a fundamentação para a compreensão da realização estrutural de cada tipo de seleção até o modo como cada uma disponibiliza sua complexidade para a realização da outra (ou seja, sua coevolução). 


\section{Capítulo 3}

\section{Sistemas de Sentido: a regência da informação}

Como podemos compreender a realização da informação nas esferas do individual (sistemas psíquicos) e do coletivo (sistemas sociais)? E como podemos compreender, e discernir, a passagem do sentido de uma seleção individual para uma seleção social (e vice-versa)? Acreditamos que a chave para isso está em seguir as possibilidades de transformação que cada seleção propícia e, mais do que isso, como essas possibilidades são regidas pelas características da operação que realiza essa transformação. Assumimos, então, que informação é essencialmente transformação e que, para o modo como cada sistema permite uma transformação em sua estrutura, existe um regime específico que granjeia a derivação dessa transformação. É esse regime, um regime de informação, que governa as possibilidades de constituição de um sistema, e de que ele possa ser observado como um todo coerente (não necessariamente unitário: sistemas sociais são formações coerentes, mas que podem não apresentar uma aparência de unidade). Aqui regime deve ser entendido no sentido de algo que governa as (possibilidades) de transformações de um sistema, tanto em sua gênese quanto na manutenção da organização que dá sentido e função a esse sistema. Portanto, embora possamos vir a usar a expressão regime de informação numa forma abreviada, ele deve ser entendido como um regime sistêmico ou constitutivo de informação, uma vez que não usaremos informação no sentido largo que costuma ser usado (para metaforizar qualquer coisa que pareça ou possa ser conotada como informação), mas no sentido já exposto de uma diferença constitutiva nas possibilidades de organização de um sistema.

Por estas razões é que devemos nos deter primeiro para tecer as diferenças e aproximações com o termo regime de informação como é empregado em Ciência da Informação. De forma geral, esse termo designa um conceito que procura romper os limites disciplinares restritos que a questão da informação costuma ter em Ciência da Informação, acrescentando-lhe as dimensões políticas e sociais como verdadeiros centros dessa questão. González de Gomez (2008, 2012), que tem trabalhado 
pioneiramente esse conceito no Brasil, associa os processos culturais e sociais aos processos de decisões políticas e às estruturas de poder (fluxos tecnológicos) que regulam ou mudam esses regimes:

Em nossos estudos, definimos um regime de informação pelo modo de produção informacional dominante numa formação social, que prescreve sujeitos, instituições, regras e autoridades informacionais, meios e recursos preferenciais de informação, padrões de excelência e critérios para seu processamento seletivo. Cada vez que muda ou mudam os eixos de ênfases e relevância, mudam também todos ou muitos dos parâmetros que configuram o "lócus" de entendimento e definição de recursos e ações de informação. Ao mesmo tempo, cada nova configuração de um regime de informação, resulta de e condiciona diferentes modos de configuração de uma ordem sócio-cultural e política. (GONZÁLEZ DE GOMEZ, 2012, p. $32)$.

Antes de se juntarem numa só expressão, porém, "regime" e "informação" possuem, em Ciência da Informação, um percurso epistemológico de interlocução conceitual através de várias abordagens.

O "regime de informação" ou o "regime global de política de informação" são conceitos que veem sendo trabalhados na Ciência da Informação como uma forma de se obter uma paisagem do campo de ação da política de informação relacionando atores, tecnologias, representações, normas, e padrões regulatórios que configuram políticas implícitas ou explícitas de informação.

Curiosamente, de formas diferentes, dois autores, Frohmman (1995) e Braman (2004) associam os termos "regime" e "informação" numa tentativa de compreender como os processos de informação se delineiam, se ordenam e se estabilizam no âmbito de uma sociedade guiada pelas tecnologias da informação e da comunicação inseridas em uma forte economia de mercado. (MAGNANI ; PINHEIRO, 2011, p. 596).

Ao que pontuam Magnani e Pinheiro, de que o conceito de regime de informação como idéia carece ainda de um maior estudo e compreensão, nós acrescentamos algumas observações quanto à sua construção conceitual à luz do que foi exposto até aqui. A primeira é em relação à ideia de informação que está latente em alguns desses estudos, como um objeto que pode ser considerado independente, algo em si mesmo, que pode ser estocado e transmitido. Magnani e Pinheiro, por exemplo, afirmam que o conceito de regime de informação não se prende à "informação em si mesma”, e que pelo contrário se volta para um objeto real, "o conjunto de relações que a informação estabelece ao redor dos múltiplos interesses de atores e pela adoção 
específica de artefatos direcionados pelas práticas informacionais desses sujeitos" (MAGNANI; PINHEIRO, 2011, p. 608). Ou seja, esse ponto de vista defendido por Magnani e Pinheiro estabelece que existiria algo como uma informação em si mesma, separada, e os regimes de informação que constituiriam esse campo relacional. Deste modo, a informação é naturalizada, já está lá, está dada, e é estabelecido um continuum entre estruturas de informação e os campos relacionais que envolvem os atores sociais. Esta visão da questão escamoteia o problema do fenômeno da informação, de como esta envolve as estruturas de informação e as relações que atribuem sentido a essas estruturas. A consequência disso é que a relação entre estruturas e tecnologias da informação e os campos de sentido, suas tensões e contradições, que se formam nessa relação ficam pouco claros, forçando a reificação constante daquilo que se expõe como sendo um regime de informação (quando é sempre incorporada ao meio que se observa, como informação na mídia, informação digital, informação visual, informação das bases de dados, etc.).

Uma abordagem fenomenológica da informação, a partir dos regimes sistêmicos que perfazem a informação, poderia agregar uma clareza a essa transição entre estruturas de poder e campos de força, uma vez que estes poderiam passar a ser definidos pela natureza sistêmica pela qual são instanciados. Em outras palavras, poderíamos descortinar o que rege um regime de informação, isto é, poderíamos discriminar sob qual domínio sistêmico cai uma determinada observação sobre o uso e transformação da informação em determinados campos de forças sociais e sua interação com as estruturas de poder. Ou seja, antes de partirmos para regimes de informação políticos, tecnológicos ou sociais (e suas interrelações), observaríamos um regime mais amplo, configurador destes últimos, e por isso mesmo, sistêmico.

Para chegarmos a essa observação, sem cairmos no erro de considerarmos como sistêmico um enquadramento mecanicista do problema da informação, procederemos de forma indutiva, através da pergunta pela diferença entre atribuir informação e obter informação. Assim, estaremos trabalhando na questão de forma basal, a partir da operação da construção do sentido sob regimes diferenciados (sistemas de sentido). Essa diferença se estabelecerá através da diferença entre fazer uma distinção que ordena o mundo e manejar o que foi distinguido (organizar).

A pergunta a se fazer primeiro, portanto, é: ao que posso atribuir informação? E a segunda é: quando observo que algo possui informação? 
À primeira pergunta responderemos com um exercício mental. Imaginemos uma cadeira, um objeto comum o qual categorizamos rapidamente como algo com respaldo, um assento e quatro pernas para equilibrar o conjunto. Uma categoria básica, como argumentaria Eleonor Rosch. Contudo, o que me impede de continuar reorganizando o que vejo sob diversos pontos de vista? Posso categorizar essa cadeira como um objeto de luxo (ou o seu contrário), categorizando pela escolha das cores, das formas e dos detalhes. Posso categorizar essa cadeira pelo seu design, se se a qualifica como um objeto caseiro ou de escritório. Posso categorizá-la como um objeto museológico, de acordo com sua idade, a quem pertenceu, ou se fez parte de algum evento histórico. Posso categorizar essa cadeira como um objeto religioso, se esta cadeira simboliza algo de espiritual, seja porque faz parte de um ritual ou se, por exemplo, posso distinguir em alguma de suas partes algo como o rosto da Virgem Maria ou de Jesus. Posso também combinar qualquer uma destas características e fazer categorizações cada vez mais complexas. Até aqui estou organizando e reorganizando o que vejo (ou imagino), realizando distinções sucessivas que me trazem à mão um objeto organizado de um modo ou outro, ou seja, estou atribuindo informação (atribuindo uma organização específica) a um objeto, na verdade, percebendo esse objeto através dessas distinções. No entanto, a pergunta pela informação só surge quando paro e me pergunto que informação essa cadeira possui. Então me deparo com o paradoxo de que toda essa informação quase infinita que posso atribuir ao objeto pode ser igualmente retirada, porque mesmo na categorização mais básica é preciso atribuir uma organização, por mínima que seja. Ou seja, para obter informação é preciso primeiro atribuí-la (eis o paradoxo).

Mesmo que eu catalogue todas as categorizações possíveis isso nada nos dirá sobre a informação que o objeto possui enquanto eu continuar atribuindo informação, porque o limite dessa atribuição está em quem a atribui, não no objeto. A questão então passa a ser não a informação que eu atribuo (a organização atribuída), mas a organização como uma estrutura que eu posso manejar. É nesse momento que nos deparamos com a limitação da atribuição de informação, porque em nenhuma dessas atribuições será possível dizer que esta pertence à cadeira, porque não basta colocá-la no museu para que seja uma peça histórica, ou colocá-la no terreiro de umbanda para que seja um ícone espiritual, para isso será necessário cercá-la de um contexto que não pertence à cadeira. Ficaríamos com a constatação que a cadeira não possui informação. 
Mesmo na sua categorização mais básica, a de objeto de se sentar, depende de primeiro atribuir uma organização com esse fim. Em outras palavras, se eu não distinguir uma organização não existirá informação suficiente para evocar um objeto. Ou seja, a evocação de um objeto (atribuir-lhe um uso ou contexto) só acontece quando o distingo, não está dado na estrutura do objeto.

Isso leva à constatação que a estrutura em si não transmite informação porque o máximo que posso fazer é intervir nesta com base numa distinção prévia, não verei a cadeira se transformando em alguma outra coisa que não previ. Se esperar bastante tempo, o máximo que observarei será a degradação da estrutura até que não seja possível distinguir ali aquela organização prévia. O máximo que podemos fazer, então, é conservar todos os parâmetros possíveis desse objeto, daquilo que o distingue, mas então estarei reduzindo todas as outras possibilidades. O cerne da operação de atribuição de informação está em distinguir uma organização que posso manejar, mas à qual se chega atribuindo-lhe características específicas, ou seja, reduzindo-a a uma caracterização (a cadeira se torna um objeto de decoração quando especifico as características que me permitem fazer dela esse tipo de objeto). Fazendo isso, porém, cancelamos todas as possibilidades gerativas, o que significa que não veremos nada de novo surgindo, nenhuma transformação além daquilo que tenha sido caracterizado. Mesmo se chegarmos a um alto nível de caracterização, por exemplo, e formos capazes de descrever a cadeira até o último estado quântico que a perfaz, poderemos até mesmo teletransportar (teoricamente) a cadeira, mas nada de novo terá sido gerado. Uma atribuição de informação é, em suma, a observação continuada (não perturbada) de uma caracterização.

A pergunta pela informação (como a obtemos), portanto, invoca a questão da transformação. De fato, diremos que algo possui informação quando observarmos que lhe podemos atribuir transformação, justamente porque transformação significa passar de uma atribuição de informação para outra, gerando uma descontinuidade nessa atribuição que nos choca ou maravilha por gerar uma mudança numa caracterização. $\mathrm{O}$ quão descontínuo será essa atribuição dependerá de nossa capacidade de prever a transformação de uma organização em outra, o que pragmaticamente se traduz pela capacidade de derivar uma caracterização de outra (e o que implica, em algum momento, a redução de uma pela outra). Transformações menos chocantes, embora causem nossa maravilha pela complexidade, são as que observamos, por exemplo, nas 
sondas espaciais que nos permitem conhecer o espaço e os outros planetas, nas quais vemos a informação executar uma série complexa de transformações previsíveis dentro do alcance do que foi programado (há uma linearidade na caracterização dos eventos). Porém, o choque acontece quando a atribuição de informação é tão descontínua em relação a atribuições precedentes de informação que temos dificuldade em dizer o que estamos observando, por exemplo, como quando Marco Polo ficou sem palavras diante de um rinoceronte, espécie desconhecida dele até então.

Ao se defrontar, em Java, com animais nunca vistos (hoje, rinocerontes), Marco Polo procura identificá-los (e nomeá-los) com base em seu estoque anterior de conhecimentos: lançando mão de características de animais que já conhece e a partir das descrições disponíveis em sua cultura, tenta estabelecer relações e, por aproximação, classifica o novo a partir de referências existentes. Se de imediato identifica-os com os unicórnios - seu corpo, as quatro patas, um chifre acima do nariz, etc., - rapidamente verifica que a classificação feita não é inteiramente própria, uma vez que, nessa comparação, constata a existência de diferenças relativamente ao modelo anterior. (LARA, 2002, p. 128).

Geralmente esta situação de Marco Polo não é tratada como um problema de percepção, justamente por se considerar a atividade de nomear (ou identificar) como separada da percepção. Porém, não seria nomear, designar ou identificar uma operação de percepção por outros meios? Umberto Eco trabalhou sobre essa questão, se perguntando como chegamos das coisas aos nomes das coisas (ECO, 1998). Eco imagina a existência de um continuum indiferenciado, que seria como o substrato da realidade ao opor linhas de tendências e resistências às nossas interpretações. Nomear algo seria como contornar toda a trama de negações que nos impedem, finalmente, de chamar o rinoceronte de unicórnio, assim chegando ao nome rinoceronte. Essas linhas funcionariam em sinal negativo, e embora Eco afirme (ECO, 1998, p. 52) que uma lei derivada dessas linhas de resistência não seja a representação das mesmas, mas apenas uma adequação, a ideia não consegue se livrar da noção agostiniana de um imprimatum das coisas da natureza em nossa mente. Ora, a impressão de algo sobre um molde não é necessariamente feita por recortes positivos, mas também pela imposição de um fundo em negativo que traz à tona o relevo desejado! Esse representacionismo oculto na argumentação de Eco, o leva a considerar que a interpretação paga certo tributo à Realidade. 
Afirmar que existem linhas de resistência quer dizer apenas que, mesmo que apareça como efeito da linguagem, o ser não o é no sentido em que a linguagem livremente o constrói. [...] A linguagem não constrói o ser ex novo: interroga-o, encontrando sempre e de algum modo algo já dado (mesmo que já ser dado não signifique já estar acabado e completo). Ainda que o ser estivesse carcomido, existiria sempre um tecido cuja trama e urdidura, confundidas pelos infinitos buracos que corroeram, subsistem de algum modo obstinado. (ECO, 1998, p. 52).

O principal problema deste ponto de vista é o de reintroduzir, sub-repticiamente, o dualismo objetivo-subjetivo do cognitivismo ao reelaborar a separação entre o que se percebe e o que se atribui como uma separação entre o indiferenciado (A Realidade) e o diferenciado (a interpretação). Essa separação é, na verdade, o cerne da abordagem representacionista, uma atribuição de informação que é arbitrária porque construída, mas que traz em si algo que provém da realidade indiferenciada, o que leva o construído a contraditoriamente buscar sua legitimidade na realidade indiferenciada. Como essa realidade fica obscurecida (indiferenciada), recorre-se à noção de uma enciclopédia de representações (interpretações adequadas) para ser confrontada com o que se vê (a informação percebida). Ou seja, mesmo que não admitida, a informação como dado ${ }^{41}$ continua lá, como pano de fundo perceptivo sobre o qual operam as representações a serem legitimadas (como atribuições válidas de organização). A principal consequência negativa desta perspectiva é a não compreensão de como surge o novo dessa "realidade indiferenciada", uma vez que só possuo a compreensão de um regime de transformação dessa diferenciação através da segmentação do conhecido, de enciclopédias memorizadas como um conjunto de "todas as interpretações, concebíveis como a biblioteca das bibliotecas, onde uma biblioteca é também um arquivo de toda a informação não verbal de algum modo registrada, das pinturas rupestres às cinematecas" (ECO apud LARA, 2002, p. 130). Nesse regime de redução de uma caracterização por outra surge sempre a questão de como segmentar o novo:

A modificação da intensão do termo unicórnio pelo acréscimo (ou eliminação) de características, interfere na extensão do termo, do que resulta que nem os unicórnios, nem os novos animais, podem pertencer, de direito, à nova classe resultante, pois os traços não são específicos nem de um, nem de outro e não servem mais para descrevê-los num mesmo conjunto. Frente a essa situação resta a alternativa de uma nova segmentação do conteúdo: Marco Polo

\footnotetext{
${ }^{41}$ Não confundir com ideia dos dados sendo construídos por informações, o "como" aqui tem o sentido de plasmar informação e dados, retirando da informação uma natureza de processo trocando-a por outra estanque, de arquivamento.
} 
poderia acrescentar um novo animal ao universo dos seres vivos. (LARA, 2002, p. 130).

Mas como segmentar o conteúdo de uma "realidade indiferenciada"? Qualquer menção à realidade pressupõe o apontar as coisas, portanto, pressupõe separar algo de seu entorno, ou de outras coisas, pressupõe assim diferenciações. O novo animal não virá de uma realidade não percebida (indiferenciada), mas de diferenças não previstas que formam uma percepção nova. Para tal, entretanto, é preciso uma noção de informação que englobe a construção dessa "realidade" junto com o interrogar dessa "realidade". Por essa razão, afirmamos que é preciso inverter o senso comum de que obtemos informação daquilo que percebemos, mas que percebemos porque realizamos distinções (criamos informação). Como afirmam Maturana e Varella (2002), existe mais atividade neural sendo produzida no cérebro (assim como em outras partes do sistema nervoso) em direção aos sentidos do que o contrário. Nas palavras destes autores, "como observadores, estamos habituados a dirigir nossa atenção para o que nos parece mais acessível - as perturbações externas" (MATURANA ROMESÍN; VARELA GARCÍA, 2002, p.180). Para estes autores, o importante é a ideia que essas perturbações só afetam o ir e vir dos equilíbrios internos e não a sua própria organização, o que eles ilustram com o que ocorre no sistema visual:

Em geral, pensamos na percepção visual como uma determinada operação sobre a imagem retiniana, cuja representação será em seguida transformada no interior do sistema nervoso. Essa é a abordagem representacionista do fenômeno. Entretanto, ela desaparece logo que nos damos conta de que, para cada neurônio da retina projetado sobre o nosso córtex visual, conectam-se a essa mesma zona mais de cem neurônios que provêm de outras partes do córtex. E mais: antes de chegar ao córtex - quando a projeção da retina entra no cérebro, no chamado núcleo geniculado lateral do tálamo (NGL) -, verifica-se que essa estrutura não age simplesmente como uma estação de passagem da retina ao córtex. Para ela convergem muitos outros centros, com múltiplos efeitos, que se superpõe à ação retiniana. [...] Ou seja, ambas as estruturas estão numa relação de efeito mútuo e não de simples sequencialidade (MATURANA ROMESÍN; VARELA GARCÍA, 2002, p.180-181).

Para os autores, portanto, fica claro que a percepção visual não provém pronta dos sentidos, mas que estes são mais "como uma voz (perturbação), que se soma às muitas vozes de uma agitada sessão de transações na bolsa de valores (relações de atividade interna entre todas as projeções convergentes), na qual cada participante ouve o que lhe interessa” (MATURANA ROMESÍN; VARELA GARCÍA, 2002, p.181). 
As pesquisas recentes em neurociência têm corroborado essa visão de Maturana e Varella, principalmente através da descoberta que o cérebro está sempre ativo, num sistema de rede de "modo padrão" (DMN, Default Mode Network, em inglês), o qual seria responsável pela organização da atividade neuronal, orquestrando memórias e vários sistemas que precisam de preparação para quando surgem eventos, como o sistema motor estar preparado (num tônus sustentado) para quando uma mosca pousa no braço e isso nos leva a coçar o local (RAICHLE, 2010, p. 25). No caso do sistema visual, o DMN (em corroboração à abordagem autopoiética de Maturana e Varela) também fornece pistas:

[...] Pesquisadores já sabem há algum tempo que do fluxo virtualmente infinito em torno do cérebro, apenas um filete de informações vai para os centros de processamento desse órgão. Embora 6 milhões de bits sejam transmitidos através do nervo óptico, por exemplo, somente 10 mil bits chegam à área de processamento virtual do cérebro; e, destes, apenas algumas centenas participam da formulação da percepção consciente - o que é escasso demais para gerar uma percepção significativa por si mesmos. A descoberta sugeriu que o cérebro provavelmente faz constantes predições sobre o ambiente externo, em antecipação a insignificantes impulsos sensoriais que chegam a ele do mundo exterior (RAICHLE, 2010, p. 25).

Raichle (2009) pontua que, além a visão tradicional do cérebro como possuindo primordialmente uma natureza reflexiva, guiado pelas demandas do ambiente, ganha importância a visão do cérebro como funcionando principalmente de modo intrínseco em suas tarefas de criar e manter informações, mais prevendo as demandas do ambiente do que apenas reagindo de forma reflexiva, o que representa uma mudança paradigmática no entendimento do funcionamento do cérebro e mesmo na compreensão do surgimento da consciência. A compreensão do papel do DMN no funcionamento do cérebro pode ser inscrita no que Maturana e Varela chamaram de clausura operacional do sistema nervoso.

[...] O sistema nervoso pode ser definido, no que se refere à sua organização, como dotado de uma clausura operacional. Isto é, está constituído de tal maneira que quaisquer que sejam suas mudanças elas geram outras modificações dentro dele mesmo. Assim, seu modo de operar consiste em manter certas relações entre seus componentes invariantes diante das perturbações que geram, tanto na dinâmica interna quanto nas interações do organismo de que faz parte. Em outras palavras, o sistema nervoso funciona como uma rede fechada de mudanças de relações de atividade entre seus componentes. (MATURANA ROMESÍN; VARELA GARCÍA, 2002, p. 183). 
A proposta de Matura e Varela sobre o fechamento operacional do sistema nervoso fornece uma saída para o dualismo imposto entre objetivismo e solipcismo pelo paradigma representacionista, como havíamos discutido anteriormente ao tratar do prevalecimento desse paradigma no trato das questões cognitivas dentro do campo do tratamento da informação e do conhecimento.

É interessante notar que a clausura operacional do sistema nervoso nos diz que seu funcionamento não cai em nenhum dos extremos: nem o representacionista nem o solipsista. O sistema não é solipsista porque, como parte do organismo, participa das interações deste com seu meio, que nele desencadeia continuamente mudanças estruturais que modulam sua dinâmica de estados. [...] O sistema nervoso também não é representacionista, porque em cada interação é seu estado estrutural que especifica quais as perturbações que são possíveis, e que mudanças elas podem desencadear em sua dinâmica de estados. [...] Dito de outro modo: o sistema nervoso não "capta informações" do meio, como frequentemente se diz. Ao contrário, ele constrói um mundo, ao especificar quais configurações do meio são perturbações e que mudanças estas desencadeiam no organismo. (MATURANA ROMESÍN; VARELA GARCÍA, 2002, p. 188).

Desta forma, poderíamos considerar tanto o que é percebido (a "realidade") quanto o que é atribuído (o que é categorizado e consequentemente caracterizado) como igualmente construído. Ou seja, a realidade seria como um todo um construto, no qual a informação se refere a modos diferenciados de realizar distinções. Esses modos devem ser referidos a como conseguimos observar transformações e assim tanto sustentar quanto criar objetos no mundo. Os modos como conseguimos lidar com essas transformações, contudo, é que definirão como se configura sistemicamente um regime de informação. Essas transformações, como o fruto de diferenças que mobilizam um sistema a mudar sua organização (sendo esta a própria dinâmica da informação), podem ser compreendidas em razão de como se mobilizam essas diferenças e da complexidade de suas estruturações. Se distinguirmos que o sistema muda de organização porque as diferenças foram moduladas para se atingir essa organização posterior, então observaremos um regime de informação redutivo, no qual as diferenças são equalizadas (em maior ou menor grau) para se chegar a algum propósito ou meta. Disso, concretamente, mecanismos cibernéticos e computadorizados são o exemplo mais cabal. Contudo, exemplos abstratos são mais profusos, não só porque precedem os mecanismos como exercícios teóricos do que se concretizará, mas principalmente porque projetamos no mundo uma necessidade de ordem e previsibilidade que se traduz, 
por exemplo, nas leis de identidade e do terceiro excluído da Lógica ${ }^{42}$ e nas lógicas binárias do sim/não. Nos regimes redutivos da informação, a modulação das diferenças dá vazão a um modelo mandatório, e que entra em crise se a informação percebida entra em choque com a informação atribuída.

O esforço de adequar as coisas a um modelo já existente é fruto de nossa ânsia pela estabilidade, razão pela qual experimentamos um profundo desconforto se elas não cabem nas categorias de que dispomos. Todavia, manter o padrão a todo custo pode levar-nos a organizar o mundo ao modo do leito de Procuste, quando pés e cabeças, que impedem a acomodação à cama, são simplesmente eliminados. (LARA, 2002).

Esta crise, ou descompasso, não existiria se não existisse um regime de transformações (de informação) concorrente, que se realiza na contramão das operações de equalização das diferenças. Para entender tal regime primeiro é preciso considerar a natureza mais acessível dos regimes redutivos, pois estes repousam na relação inversa entre a capacidade de mobilizar as diferenças constituintes dos sistemas e a complexidade estrutural destas diferenças. Isto significa que, para mobilizar livremente essas diferenças (compreender todos os estados de conjunção e disjunção entre uma diferença $x$ e uma diferença $y$ ), será necessário que a complexidade estrutural seja a mínima possível, abstratamente que $a$ seja sempre $a$, ou concretamente que a estrutura corresponda ou a um estado ligado ou a um estado desligado (ou excitado/não excitado). Novamente, computadores são o melhor exemplo: algoritmos mobilizam a equalização de uma miríade de diferenças, e através disso podem realizar as tarefas mais complexas possíveis e cálculos humanamente irrealizáveis, mas tudo isso repousa em última instância na mínima complexidade estrutural manejável (bits). Abstratamente, todavia, essa relação não só se replica como precede aplicações tecnológicas: sofisticados sistemas lógicos repousam na simplória presunção que as coisas no mundo possuem identidades físicas inalteráveis. Regimes de informação redutivos, enfim, possuiriam um alto grau de compreensão das operações de equalização das diferenças nos sistemas (são capazes de produzir grandes somas de dados sobre um problema), entretanto, têm uma baixa capacidade de produzir complexidade (de criar algo novo a partir desses dados).

\footnotetext{
${ }^{42}$ Formulação que visa garantir a condição de verdade de uma proposição: “ou A é B ou A não é B - não se admite uma terceira declaração".
} 
Porém, quando distinguimos um sistema que muda de organização sem que as diferenças sejam moduladas ponto a ponto, mas usadas como ponto de partida (um modelo) para a organização ulterior, então essa relação se inverterá. Nesses casos, as diferenças mobilizadas ficam obscurecidas (distinguimos menos dados ou estes parecem insuficientes), contudo, a complexidade estrutural envolvida na realização dessas diferenças é exuberante (como criação de novas formas). Tal complexidade torna difícil atribuir estados discretos manejáveis a essas estruturas, o que será exemplificado, daqui em diante, com a comparação recorrente da complexa estrutura do sistema nervoso a um sistema de comunicação (como se ambos funcionassem através de códigos de informação).

\subsection{Informação, Comunicação e Organização}

Em primeiro lugar, no plano prático, decifrar um código e, de certa forma geral, a aplicação da teoria de Shannon pressupõe que seja possível identificar um certo número de estados discerníveis à entrada e saída de um canal e no próprio canal, que constituem os símbolos do ou dos alfabetos utilizados nas mensagens que procuramos decifrar. [...] No que respeita ao sistema nervoso, a primeira dificuldade reside no facto de nem sempre sabermos quais são os sinais que devemos considerar como símbolos de mensagens a decifrar. Evidentemente, os impulsos elétricos - ou influxos ou spikes - recolhidos ao nível das fibras nervosas e dos neurônios são os primeiros candidatos a esse papel. Mas estão longe de ser os únicos e, como diz A. Fessard, há demasiados estados discerníveis possíveis sem que saibamos quais devem ser tidos em consideração. (ATLAN, 2008, p.167-168).

Por um sistema distinguido como organizado, não queremos dizer altamente organizado como o entende Shannon, ou seja, como uma fonte de eventos não independentes (uma fonte de Markov), o qual seria como um padrão em que o conhecimento de suas partes diminui a indeterminação quanto às partes restantes (DA SILVA, 1996, p. 116). Seguimos Shannon, porém, em que é essencial distinguir entre eventos relevantes e irrelevantes para que exista informação. Mas nos afastamos deste teórico quando este operacionaliza essa distinção através de uma probabilística, baseada na noção de "que não pode haver transmissão de informação sem o pressuposto de uma correlação nômica - i.e., uma ordem regida por regras - entre eventos no mundo" (DA SILVA, 1996, p. 106). Esta correlação implica que em algum momento as diferenças entre fonte e receptor são reduzidas para que um sinal inequívoco flua entre elas. Tal compreensão da informação leva a regimes de transformação nos quais a 
indeterminação é uma grandeza probabilística calculável, e nunca uma contingência histórica (uma escolha assimétrica em relação à fonte). Aplicar esta compreensão da informação aos processos vivos levaria à conclusão, por exemplo, que a vida, como fenômeno auto-orgnizado, seria improvável de surgir espontaneamente a partir de uma sopa de proteínas básicas (DA SILVA, 1996, p. 127). Da Silva argumenta que precisamos apenas encontrar melhores roteiros de auto-organização para serem avaliados pelo instrumental teórico da Teoria da Informação. Mas contra-argumentamos que a Teoria da Informação possui um gargalo: a necessidade de correlação nômica para a comunicação. Tal correlação implica que a indeterminação da fonte não geraria compreensão no receptor quanto à mensagem nessa fonte, impondo que se opte por um decaimento clássico de correlação entre identidades (correlação entre estados).

Porém, sem um regime que propague sua organização (que a comunique) sem que este seja uma imposição ponto a ponto de seus estados diferenciados, mas um regime aberto a rearranjos, invertendo a equação de uma alta compreensão das probabilidades de seleção e uma baixa comunicação destas probabilidades (decaídas pela lógica da identidade e da escolha dual sim/não), não teremos como explicar os regimes produtivos da vida e do sentido. Para estes, precisamos pensar a complexidade com algo mais do que apenas incorporação do ruído, como o sugere Atlan.

Quando falamos de sistemas organizados complexos (como os vivos) estamos falando de sistemas que se transformam assimetricamente de um estágio evolutivo a outro, então não caberia falar de um regime de informação (de transformação de uma organização em outra) regido por correlações nômicas, embora possamos conotar alguns de seus processos como assim acontecendo, como os genéticos ${ }^{43}$. O ser vivo, porém, não pode ser descrito como uma forma final, ele nunca está "pronto", portanto, não é especificado a partir de uma fonte genética, e, no entanto, ele é sempre uma forma específica, mesmo quando muda, o que o configura como uma totalidade (unidade) que não é construída passo a passo através de unidades discretas discerníveis.

As noções tais como codificação e transmissão de informações não entram na determinação de um sistema autopoiético concreto porque não se constituem em elementos causais. Assim, a noção de especificidade não implica codificação, informação, nem

\footnotetext{
43 “A relação causal-informacional entre o 'alfabeto' das bases de nucleotídeos e o 'alfabeto' dos aminoácidos convida, de modo quase irrecusável, um tratamento informacional. A ordem envolvida no processo de síntese de proteínas pela 'leitura' da 'mensagem' genética contida nas moléculas de DNA parece encontrar na Teoria da Informação uma linguagem útil.” (DA SILVA, 1996, p. 125).
} 
instruções: somente descreve certas relações determinadas dependentes da organização autopoiética, que têm como resultado a produção dos componentes específicos. A dimensão correta é a de relações de especificidade. Dizer que o sistema, ou parte dele, codifica a especificidade, não é só uma má designação, mas também induz ao erro; e isto porque essa expressão representa a aplicação de um processo que ocorre no espaço da autopoiese em um processo do desenho humano (heteropoiese), e não uma reformulação do fenômeno. A noção de codificação é uma noção cognoscitiva que representa as interações do observador, e não um fenômeno operacional no domínio físico. ${ }^{44}$ (MATURANA ROMESÍN; VARELA GARCÍA, 2004, p. 81, tradução nossa).

A partir disto, podemos entender a opção da Cibernética (abordada no capítulo precedente) pelas características de feedback negativo do organismo, pois estas são plenamente acessíveis como interações do observador, o qual pode conotar seus próprios critérios de desvio como uma regulação do organismo. Apesar de operacionalmente válida, esta noção apenas seria coerente no campo das descrições:

Esta noção é válida no campo de descrição da heteropoiese, e reflete a observação e descrição simultâneas pelo projetista (ou seu equivalente) de transições interdependentes do sistema que ocorre em uma ordem preestabelecida e numa velocidade específica. A dimensão correspondente em um sistema autopoiético é a produção de ordem; mas outra vez aqui no contexto da autopoiese, e não no de nenhum estado particular do sistema que apareça projetado no nosso campo de descrições. A noção de regulação pode, pois, entrar na descrição, mas não se constitui num elemento causal da organização autopoiética. ${ }^{45}$ (MATURANA ROMESÍN; VARELA GARCÍA, 2004, p. 82, tradução nossa).

\footnotetext{
${ }^{44}$ Las nociones tales como codificación y transmisión de informaciones no entran em la determinación de um sistema autopoiético concreto, porque no constituyen en él elementos causales. Así, la noción de especificidad no implica codificación, información ni instrucciones; solamente describe ciertas relaciones determinadas dependientes de la organización autopoiética, que dan por resultado la producción de los componentes específicos. La dimensión correcta es la de las relaciones de especificidad. Decir que el sistema, o parte de él, codifica la especificidad, no es sólo uma mala designación, sino también induce a error; y esto, porque esa expresión representa la aplicación de un processo que ocurre en el espacio de la autopoiesis a un proceso que ocurre en el espacio del diseño humano (heteropoiesis), y no una reformulación del fenómeno. La noción de codificación es una noción cognoscitiva que representa las interaciones del observador, y no un fenómeno operativo en el domínio fisico. (MATURANA ROMESÍN e VARELA GARCÍA, 2004, p. 81).

${ }^{45}$ Esta noción es válida en el campo de descripción de la heteropoiesis, y reflexa la observación y descripción simultáneas, por el diseñador (o su equivalente), de transiciones interdependientes del sistema que ocurren en un orden preestabelecido y a velocidades especificadas. La dimensión correspondiente en um sistema autopoiético es la producción de orden; pero outra vez aquí en el contexto de la autopoiesis, y no de ningún estado particular del sistema que aparezca proyectado en nuestro campo de descripciones. La noción de regulación puede, pues, entrar em la descripción, pero no constituye un elemento causal de la organización autopoiética. (MATURANA ROMESÍN e VARELA GARCÍA, 2004, p.82).
} 
Por outro lado, o feedback positivo, por não poder ser conotado como um desvio em relação a uma ordem preestabelecida, permanece longe das interações do observador, que não pode assinalá-lo nem como regulação e nem como mensagem. Sendo o feedback positivo, o mecanismo morfogenético que gera a complexidade, induzindo mudanças qualitativas (isto é, adaptativas e evolutivas), é a própria geração e transformação da vida que escapa à observação, mais especificamente, à atribuição de informação como diferenças definidoras. Ou seja, as formas vivas são como "caixas pretas" quanto às diferenças que definem suas transformações. Seria enganoso, portanto, usar a expressão "informação instrutiva" para designar como os seres vivos propagam sua própria organização, como o sugere Logan (2012). Sendo estes inescrutáveis a uma soma de todas as diferenças que os definem como unidade, no entanto, eles oferecem uma complexidade de interações e sentidos que se autoproduz como unidade. Isto tem uma consequência dupla: como unidades biológicas elas passam para frente o mesmo processo autopoiético que as produziu como unidade, criando descendência, mas como unidades individuais o próprio processo autopoiético se esgota na produção da ontogenia individual.

Em outras palavras, toda conduta produzida pelos processos autopoiéticos da unidade não é compartilhada por outras unidades da mesma espécie. Este é um ponto crucial, uma vez que as unidades (isto é, os indivíduos) não podem compartilhar suas diferenças (e assim equalizá-las) em qualquer nível: fisiológico, nervoso e comportamental. Para mobilizar qualquer um desses sistemas em outra unidade, o indivíduo não pode recorrer ao expediente de transmitir uma diferenciação integrada de qualquer nível (nervosa ou comportamental) para o sistema do indivíduo mais próximo porque isso causaria uma interrupção no processo autopoiético que torna esse indivíduo uma unidade (com consequências danosas). Contudo, a unidade oferece complexidade. Com isso queremos dizer: uma chance de interagir, uma vez que o próprio processo (autopoiese) que obscurece as escolhas que levaram à complexidade da unidade, por outro lado, oferece o surgimento da própria escolha através da oferta de formas múltiplas de interação. A escolha surge como inerente à própria complexidade da interação, como uma necessidade de estabelecer as diferenças entre duas (ou mais) unidades.

[...] o princípio que realmente obriga à seleção (e nesta medida que o configura) é a diferença entre duas complexidades. E falando não de estados, mas de operações, ambos são redução de complexidade, ou 
seja, redução de uma complexidade por outra. ${ }^{46}$ (LUHMANN, 1990, p. 75, tradução nossa, grifos nossos).

Estas operações de escolha não devem, porém, ser confundidas com simples operações de seleção (como na Teoria da Informação de Shannon), a qual se baseia na indiferença da escolha justamente porque as diferenças podem ser correlacionadas com precisão para se ajustarem à seleção. No caso da interação entre as unidades autopoiéticas (sejam estas simples protozoários, rinocerontes ou seres humanos), as diferenças nunca chegam a ser correlacionar sob nenhuma dimensão, uma vez que não existe uma comensurabilidade ${ }^{47}$ entre estes organismos (tanto como espécies quanto como indivíduos). A operação que resta às unidades autopoiéticas é a escolha de uma forma de interação que se coordene mutuamente, e esta não será definitivamente uma escolha indiferente, mas uma terceira diferença de caráter vital por vincular duas diferenças que nunca se tornarão comensuráveis. O que se seleciona, portanto, é um vínculo de sentido, e não um estado determinado que possa ser manejado ou intercambiado por outro, porque o que se tenta reduzir não são as diferenças, mas complexidade, o que requer produzir algo igualmente diferenciado ${ }^{48}$ (ou seja, outra complexidade) para lhe fazer face (interagir). O que emerge disto tudo como fenômeno é um regime de informação (de transformações) que comunica não orientado pelo compartilhamento do que é comum, mas pelas diferenças passíveis de coordenação, e por isso torna-se um regime produtor de estados novos.

[...] um contato transmitido para além dos limites, não proporciona a nenhum sistema a plena complexidade do outro, nem mesmo se esse tivesse capacidade suficiente de tratamento da informação. A organização interna da interrelação seletiva com ajuda de órgãos delimitantes diferenciados tem, em cada, caso como consequência que os sistemas se fazem indetermináveis um para o outro, surgindo, assim, novos sistemas (sistemas de comunicação) para regular esta indeterminabilidade. $^{49}$ (LUHMANN, 1990, p. 80, grifo nosso).

\footnotetext{
${ }^{46}$ [...] el principio que realmente obliga a la selección (y en esta medida lo configura) es la diferencia entre dos complexidades. Y hablando no de estados sino de operaciones, ambos son reducción de complejidad, es decir, reducción de una complejidad por otra. (LUHMANN, 1990, p. 75).

${ }^{47}$ Não confundir comensurabilidade com compatibilidade. Podemos intercambiar muitos tipos de órgãos ou tecidos entre indivíduos da mesma espécie (ou até entre indivíduos de espécies diferentes), mas isto não quer dizer que as diferenças entre estes se igualem, muito menos que o transplante deste irá replicar o desempenho desse órgão no receptor.

${ }^{48}$ A própria tese que aqui desenvolvemos pode ser vista como uma tentativa de reduzir uma complexidade (o problema da informação) por outra (a informação como um fenômeno sistêmico).

49 [...] un contacto transmitido más allá de los límites, no proporciona a ningún sistema la plena complejidad del otro, ni aun cuando éste tuviera la suficiente capacidad de tratamiento de información. La organización interna de la interrelación selectiva con ayuda de órganos delimitantes diferenciados tiene en cada caso como consecuencia que los sistemas se hagan indeterminables uno para otro, surgiendo así nuevos sistemas (sistemas de comunicación) para regular esta indeterminabilidad.(LUHMANN, 1990, p. 80).
} 
Enfim, a unidade autopoiética obscurece suas determinações para poder oferecer um sentido, isto posto como um conjunto complexo de disposições, inclinações e direcionamentos, que só se consomem como sentido quando selecionados como vínculos entre diversos direcionamentos num espaço relacional. Ou seja, sentido, nesse regime de informação, não deve ser entendido como construído a partir da seleção indiferente de mensagens, mas como selecionando vínculos entre formas de interação que qualificam esse espaço relacional. Este espaço relacional confluente é ao mesmo tempo condição e consequência para os vínculos de sentido e de sua operacionalização sob a dupla contingência do vincular/desvincular. $\mathrm{E}$ tanto o vincular quanto o desvincular são sempre assimétricos em relação às escolhas precedentes porque estão sempre a recriar o espaço relacional confluente que lhe serve de condição necessária, possibilitando assim uma produtividade sempre crescente de sentidos (semiose) regulada justamente pela sistematização desse binarismo (vincular/desvincular).

A operação de informação subjacente é da coordenação de seleções, a qual cria o vínculo relacional entre disposições, inclinações e direcionamentos distintos (que correspondem a percepções construídas diferentemente em cada indivíduo, não acessíveis diretamente) o qual, por sua vez, configura um espaço relacional confluente que serve como um espaço de percepções construídas em comum, a despeito de não se supor aqui a necessidade de existir um mundo comum de percepções. É a partir desta última condição que se bifurca a compreensão que se pode ter da comunicação e que os dois regimes de informação, os quais formam o núcleo do argumento que tentamos demonstrar, ficam mais claros e distintos.

A bifurcação ocorre em torno da possibilidade da comunicação como compartilhamento ou como diferenciação. Como primeira possibilidade, a comunicação ocorre pelo compartilhamento de um mundo comum de percepções que possibilita que as diferenças que existem entre as percepções dos indivíduos possam ser equacionadas através de denominadores comuns a estas, reduzindo assim as "arestas" entre as diferenças e permitindo a condução da informação (logo, a comunicação) entre os indivíduos - esta é a perspectiva do regime reducionista da informação. Na segunda possibilidade, a comunicação ocorre justamente pela via contrária: as diferenças são 
coordenadas para criar uma zona de percepção em comum ${ }^{50}$ na qual as "arestas" não são reduzidas, mas permanecem como novas possibilidades, em potencial, para coordenações posteriores $^{51}$. Nesta segunda possiblidade, a comunicação não é lograda pela condução de uma informação inequívoca (na qual uma diferença foi reduzida por outra), a qual se torna compartilhada por se repetir de modo igual, mas pela condução do próprio campo de tensões entre as diferenças, portanto, pela condução da possibilidade de produzir escolhas - este é o regime produtor de complexidade da informação. Este regime é mais difícil de compreender justamente porque precede as escolhas em si; uma vez que se escolhe aquilo de que se fala (a informação), perdem-se de vista todas as diferentes opções que viriam a constituir esse "aquilo". Essas opções podem ser entendidas como todos os laços cooperantes, das mais diversas naturezas, que podem estar por detrás até da mais simples das seleções de informação. Luhmann, a respeito disso, cita que "Derrida faz alusão a que todo fator cooperante não deixa rastros" (LUHMANN, 2009, p. 269).

Essa seleção pode ser sob um regime reducionista ou expansivo de informação, no entanto, apenas a seleção produtiva pode continuar ofertando sentidos (escolhas livres de determinismos), inclusive para uma posterior seleção redutiva da informação (que pode apenas concatenar uma redução à outra). Isto significa que os regimes expansivos de informação são primários, não no sentido de uma hierarquia, mas no de oferecer uma complexidade abundante que pode ser distinguida, a posteriori, como unidades dependentes. Regimes redutivos da informação não precisam ser vistos como necessariamente limitadores da produção de sentido (até porque também oferecem complexidade ao reter diferenças que poderiam se dissipar para sempre - como toda a

\footnotetext{
50 Mas sem essas diferenças temos apenas um acoplamento na percepção: por exemplo, entre dois indivíduos pode existir uma diferença na construção perceptiva do vermelho, que pode ser neurológica (o qualia, em latim, isto é, a última percepção irredutível de qualquer qualidade perceptiva), ou situacional (para um dos dois, a luz pode incidir um pouco diferente, mudando o matiz ou a intensidade), no entanto, se essas diferenças forem insignificantes na coordenação, o acoplamento perceptivo se dará sem que exista nenhuma informação, ou seja, sem nenhuma diferença relevante que obrigue à reorientação no acoplamento comportamental (o reconhecimento do vermelho como vermelho).

${ }^{51}$ Essa potencialidade reside nas margens divergentes das diferenças em coordenação, como vetores para contextualizações possíveis. Esses vetores primeiro rompem a possibilidade de construir uma percepção em comum para depois reconstruí-la em outro nível. Por exemplo, se entre dois indivíduos observando o sinal vermelho no trânsito um deles for daltônico, o fato deste último não enxergar o vermelho não será problema porque a coordenação entre os dois passa para o nível posicional da luz do sinal. Mas se imaginarmos que um dos indivíduos é oriundo de uma cultura onde o vermelho significa passar em vez de parar não existirá nível de coordenação em comum para evitar um possível desastre automobilístico. O que sobressai nestes exemplos é que a orientação no mundo não é comandada por uma realidade externa (se o semáforo está vermelho ou não), mas pelas possibilidades de coordenação reservadas pelos vários níveis de interação.
} 
informação retida nas mídias eletrônicas, por exemplo), mas nem tudo que é produzido nos regimes produtores de sentido cabe (isto é, não pode ser abarcado por um processo que é menos abrangente que ele próprio) dentro das lógicas submetidas à continuidade inequívoca das identidades. Um exemplo ilustrativo é o da fé: esta não pode ser comunicada nem como certeza, nem como incerteza - na verdade ela retém esses dois valores para transcendê-los como uma seleção de sentido única. O que tentaremos demonstrar a seguir é como esses sentidos concorrentes se aglutinam para formar sentidos integrados.

\subsection{A Regência da Informação nos Sistemas Psíquicos e Sociais}

Para compreender, porém, como esses dois regimes se relacionam é necessário discutir como o modo de cada um trabalhar (redução ou produção) com as diferenças pode ser contextualizado como modo de seleção, isto é, a partir de onde os posicionamos nos sistemas de sentido. Entenderemos estes sistemas a partir da compreensão dialógica do fenômeno da informação, como uma diferença apontada entre alguém e algum outro, como essa diferença é trabalhada (seu regime) e as possibilidades de sua realização (sob qual sistema). Sem considerar todos esses fatores em conjunto, qualquer conceito de informação será incompleto, e o não reconhecimento dessa incompletude redundará numa compreensão parcial do fenômeno.

A unidade [do conceito] de informação é o produto de um sistema - no caso da percepção, de um sistema psíquico; no caso da comunicação, de um sistema social. É preciso, portanto, sempre explicar qual sistema faz essas distinções, ou, como diz Spencer Brown, qual sistema realiza a instrução: draw a distinction, produtora de todas as distinções. (LUHMANN, 2011, p. 42).

Analisar como a informação seleciona nesses dois sistemas requer primeiro uma explicação do porque da separação nesses dois sistemas e da natureza e grau dessa separação. Essa separação é realizada em razão da noção de emergência, segundo a qual um sistema novo surge como um modo específico de organização; sempre que se observa esse modo específico de organização se estará observando a reprodução de um mesmo sistema. Esta explicação exige que se separe organização e estrutura (esta última como sendo apenas os componentes mobilizados pela organização), uma vez que é possível que mais de um sistema compartilhe a mesma estrutura. Essa distinção é necessária porque pode ocorrer da estrutura compartilhada ser contínua em sua extensão 
e, portanto, muito difícil precisar o que separa um sistema do outro ou mesmo reconhecer que o que se está observando precisa mesmo ser separado em sistemas diferentes. Esse é o caso do ser humano, cujos processos físicos, biológicos, psicológicos e comportamentais, por compartilharem um sem número de estruturas, quase sempre foram considerados como processos contíguos. A própria noção de emergência, sem um critério que separe organização e estrutura, transforma o entendimento deste fenômeno como algo rigidamente delimitado ${ }^{52}$ (enfoque metodológico) ou como um reducionismo de um processo pelo outro ${ }^{53}$. Para Luhmann,

No entanto, em nenhum dos dois enfoques, o metodológico ou o reducionista, demanda-se pelo critério que viabiliza a emergência; isto é, a diferença constitutiva pela qual um sistema se separa mediante sua respectiva operação de outros níveis de realidade. (LUHMANN, 2009, p. 263).

Quando não se obtém a compreensão dessa diferença constitutiva o que acontece? Para Maturana, o principal perigo dessa incompreensão era não distinguir entre a operação que faz surgir o sistema que se observa e a operação de observação $d o$ observador. Problema este que esse autor notou ao escutar seus colegas do MIT (Instituto de Tecnologia de Massachusetts) falarem sobre a modelagem dos seres vivos (problema sobre o qual vinha se debruçando por essa época - fins dos anos 50 - já sob a perspectiva destes serem entes autoreferentes).

A mim me parecia ouvi-los dizer que o que eles faziam não era modelar nem imitar os fenômenos biológicos, mas imitar ou modelar a aparência destes no âmbito de sua visão como observadores. [...] Não queria cometer o erro que pensava que estavam cometendo os cientistas que trabalhavam com inteligência artificial no MIT. Evitar esse erro não era fácil, pois o discurso biológico dessa época era um discurso funcional, propositivo, e falava-se dos fenômenos biológicos como se eles fossem de fato revelados ao falar da função que lhes era atribuída, e como se descrição da função especificasse os processos relacionais que lhes davam origem. Eu não pensava que não era adequado falar dessa maneira ou mesmo metaforicamente, porque me parecia que esse modo de falar ocultava conceitualmente o operar que dava origem ao fenômeno biológico que

\footnotetext{
52 "Na sociologia, por exemplo, seguindo a tradição de Durkheim, pensa-se que uma situação social só pode ser explicada por componentes sociais. A metodologia sociológica delimita o contexto social de tal forma que nele não deve ser incluído nenhum elemento de tipo psicológico ou físico. Trata-se, portanto, de compreender a emergência como um processo de delimitação frente à psicologia ou à biologia." (LUHMANN, 2009, p. 262).

53 “Já outra forma de entender o contexto da emergência é pautada pelo uso da redução (reducionismo). As situações sociais podem ser explicadas quando reduzidas a meros estados psicológicos? Pode-se elucidar o social simplesmente realizando pesquisas psicológicas entre os participantes?” (Ibid., p. 262).
} 
se queria compreender. ${ }^{54}$ (MATURANA ROMESÍN; VARELA GARCÍA, 2004, p. 13, tradução nossa).

Para este autor, portanto, era importante evitar o ocultamento provocado por aquilo que atribuímos a um fenômeno que observamos, e que é circunstanciado pelo que podemos atribuir na relação de observação. Por exemplo, ao observar um ser vivo se reproduzir, inferir daí que é constitutivo do ser vivo se reproduzir. Maturana queria evitar essa armadilha do circunstancial na observação, distinguindo a si mesmo como observador: "comecei a distinguir entre o que eu dizia como observador de acordo com a maneira como eu via o ser vivo em meu espaço de distinções, do eu dizia que se passava com este em seu operar ao estar já constituído como tal" ${ }^{\text {55 }}$ (MATURANA ROMESÍN; VARELA GARCÍA, 2004, p. 13, tradução nossa). O fundamental era distinguir essa diferença constitutiva, que separa o ser vivo dos componentes físicos que compartilha com o resto da natureza (água, carbono, lipídios, oxigênio, etc.), isto é, o que faz dele um sistema vivo enquanto sistema. Sua conclusão foi que era necessário descrever o ser vivo em termos puramente locais, específicos, evitando as generalizações funcionais e propositivas que a observação impõe: “[...] eu queria mostrar como o ser vivo surgia da dinâmica relacional de seus componentes de uma maneira alheia a toda a referência à totalidade a que estes davam origem" 56 (Ibid., p. 13, tradução nossa). A diferença constitutiva, portanto, viria a repousar nessa dinâmica relacional, sendo os componentes materiais apenas responsáveis pelo modo como uma topologia final é configurada. Como o explica Luhmann:

[...] uma célula pode ser descrita em sua totalidade, recorrendo-se exclusivamente às estruturas químicas e ao componente molecular, embora não se possa com isso descrever a autopoiese da célula. A autopoiese é um princípio de explicação que só se realiza na

\footnotetext{
${ }^{54}$ A mi me parecía al escucharlos, que lo que ellos hacían no era modelar ni imitar a los fenómenos biológicos, sino que imitar o modelar la aparencia de éstos en el ámbito de su visión como observadores. [...] No quería cometer el error que pensaba cometían los científicos que trabajan en inteligência artificial en el MIT. Evitar esse error no era fácil, pues el discurso biológico de esa época era un discurso funcional, propositivo, y se hablaba de los fenómenos biológicos como si éstos quedasen de hecho revelados al hablar de la función que se les atribuía, y como si la descripción de la función especificase los procesos relacionales que le daban origen. Yo pensaba que no era adecuado hablar así ni tan sólo metaforicamente, porque me parecía que esse modo de hablar ocultaba conceptualmente el operar que daba origen al fenómeno biológico que se queria compreender [...]. (MATURANA ROMESÍN; VARELA GARCÍA, 2004, p. 13).

55 “[...] comencé a distinguir entre lo que yo decía como observador según como veía yo en mi espacio de distinciones al ser vivo, de lo que yo decía que passaba con éste em su operar al estar yá constituido como tal”. (Ibid., p. 13).

56 "[...] yo queria mostrar como el ser vivo surgia de la dinámica relacional de sus componentes de una manera ajena a toda referencia a la totalidada que éstos daban origen”. (Ibid., p. 13).
} 
célula, e em termos da constituição da vida, e que não pode ser entendido em sua própria autonomia de reprodução, unicamente a partir de elementos químicos. (LUHMANN, 2009, p. 264).

A teoria da autopoiese, como princípio explicativo, enfim, procura mostrar a vida como a emergência de uma rede de relações que especifica a si mesma através da operação de autoprodução dessa mesma rede de relações. A diferença, então, não está no conjunto de componentes que continuamente se reproduzem, seja como formações específicas (planas, bípedes ou quadrúpedes), seja como atribuições específicas (capazes de se locomover, se reproduzir, respirar, etc.). A diferença repousa na dinâmica de autoprodução dessa totalidade.

É uma rede de produção de componentes, que resulta fechada sobre si mesma porque os componentes que produz a constituem ao gerar as mesmas dinâmicas de produções que produziram tais componentes, e que determina sua extensão como um ente circunscrito, através do qual há um contínuo fluxo de elementos que são e deixam de ser componentes à medida que participam ou deixam de participar dessa rede [...]. ${ }^{57}$ (MATURANA ROMESÍN; VARELA GARCÍA, 2004, p. 15, tradução nossa).

O que precisa ser entendido, porém, é que essa dinâmica representa uma ordem de qualificação da realidade, a qual só se sustenta enquanto sistema, isto é, enquanto o processo de autoprodução dessa dinâmica molecular específica ${ }^{58}$ for contínuo; em outras palavras, a autopoiese é um processo de produzir continuamente as próprias condições que lhe dão origem, o que tem certas consequências:

Se essa hipótese for correta, o surgimento de uma nova ordem qualitativa não poderá, então, ser deduzido das características materiais ou energéticas em que se baseia; pois, se elas se fizessem presentes na operação emergente na nova ordem qualitativa, elas provocariam efeitos de aniquilação. (LUHMANN, 2009, p. 265).

\footnotetext{
57 Es a esa red de producciones de componente, que resulta cerrada sobre sí misma porque los componentes que produce la constituyen al generar las mismas dinámicas de producciones que los produjo, y al determinar su extensión como um ente circunscrito a través del cual hay um continuo flujo de elementos que se hacen y dejan de ser componentes según participan o dejan de participar en esa red [...]. (MATURANA ROMESÍN; VARELA GARCÍA, 2004, p. 15).

58 "Una vez que en un sistema autopoiético tiene lugar el proceso autoreproductor más simple, la evolución está en marcha y la autorreproducción puede iniciar uma historia de cambios, con el consiguiente desplazamiento total (por selección natural) de qualsquiera unidades autopoiética no autorreproductoras coexistentes. De ahí la vinculación entre autopoiesis y reproducción, en los sistemas vivientes terrestres. Por supuesto, no es posible decir ahora qué ocurrió realmente al comienzo de la evolución biológica, pero ello no parece representar uma dificultad conceptual insuperable. El hecho es que, en los sistemas vivientes de hoy, la reproducción está decisivamente ligada a los ácidos nucleicos y a su papel en la especificación de proteínas." (MATURANA ROMESÍN; VARELA GARCÍA, 2004, p. 99).
} 
Isto significa que, se queremos entender o psíquico e o social como novas formas de ordenar o real, precisamos entender como se separam através de suas próprias operações de diferenciação (que são, ao fim, operações de informação). Se isto não é feito, mesmo partindo da ideia de se considerar os seres vivos como sistemas autopoiéticos, e o psíquico e o social como emergentes a partir destes últimos, pode-se ainda continuar abordando a questão a partir do senso comum, que considera o físico, o biológico, o psíquico e o comportamental ou social como um continuum. Luhmann aborda esse problema através do exemplo (paradigmático) de uma resenha sobre o conceito de autopoiese feito pelo autor Will Martens, na Kolner Zeitschrift ${ }^{59}$ :

Will Martens interpreta a proposta de comunicação no sentido de que nela se realiza uma síntese total, que alcança um processo de junção dos elementos psicológicos, biológicos e sociais. A tese defendida é a de que a sociabilidade só se efetua quando a comunicação atinge a síntese desses três componentes: a informação, enquanto trabalho de seleção praticamente biológica; $o$ ato de comunicar, que é uma mistura do biológico com o psicológico; $e$ o ato de entender, que é específico do psicológico. A emergência do social está assim constituída [na leitura de Martens] na obtenção da síntese na qual os componentes biológicos e psicológicos ficam fundidos e elevados ao social. (LUHMANN, 2009, p. 264).

Para Luhmann, esse tipo de análise sofre do "peso histórico de buscar integrar os aspectos de indivíduo e de sociedade, sem menosprezar nenhum deles" (LUHMANN, 2009, p. 264). Também pesam, e de forma fundamental, a incompreensão da informação como um fenômeno ao mesmo tempo geral e específico, cuja especificidade é dada pelo modo como esta informação é produzida. Não entender isto é submeter a compreensão do fenômeno da informação a uma dicotomia entre processos gerais e abstratos (lógicos e tecnológicos) e processos específicos (biológicos, psicológicos, sociais). É justamente a incompreensão de um princípio geral que se articula como diferentes modos de produção da informação o que acarreta nessa dicotomia, e mais: que homogeneiza cada um desses processos como se entre esses não houvesse nenhum tipo de conexão ou acoplamento. Um exemplo disto é a afirmação recorrente de que a Teoria da Informação não trataria realmente de informação, mas de meros sinais (que talvez tenham potencial de informação).

\footnotetext{
${ }^{59}$ Sem referências completas ao original citado (LUHMANN, 2009, p. 263).
} 
Considerando a informação como produto socialmente aceito e disseminado, com um caráter de "artefato", a presença humana em qualquer etapa do processo informacional é imprescindível. Daí conclui-se que este é um fenômeno eminentemente humano, ligado às esferas socioculturais, sendo que fora dela a informação não existe. Tal afirmação contradiz a teoria clássica da informação, segundo a qual até mesmo o processo de troca de bites entre máquinas é visto como uma forma de troca de informação, quando o que ocorre é uma mera troca de sinais, que podem se tornar ou não informação, se forem interpretados como tal. (AZEVEDO NETTO, 2002, p. 11).

Tal afirmação, contudo, contradiz a óbvia constatação de que a Teoria da Informação rotineiramente preenche $o$ que se espera da operacionalização da informação, isto é, a capacidade de organizar e reorganizar um sistema, e, através disso, produzir eventos de interação sem a intervenção humana ${ }^{60}$. Essa interpretação da Teoria da Informação como desumana ou incapaz de interpretar o humano advém de se confundir a teoria com a sua aplicação na comunicação. Os processos de comunicação são obviamente diferentes nas máquinas e nos seres humanos, para as primeiras depende sim da transmissão de um sinal (que equaliza as diferenças entre fonte e receptor), enquanto que para os segundos seria errôneo afirmar que qualquer coisa é transmitida, o que se observa são comportamentos de linguagem coordenados com o fim de produzirem interações coerentes. No entanto, essa diferença não é realmente observada, fazendo-se da comunicação humana um processo de transmitir informações e/ou signos, assim excluindo, ou melhor, negando a existência da informação fora do âmbito humano.

O maior prejuízo dessa interpretação é considerar a informação como um fenômeno dado, autoevidente, seja como algo transmitido ou um "artefato" objetivado nas circunstâncias da comunicação. E a autoevidência acaba tornando dispensável o que seria essencial: um princípio explicativo que explicite o que precisamos observar para dizer que estamos observando informação e, na ausência deste princípio, informação se torna a reificação do comportamento de informar-se ou informar alguém, assumindo, assim, essa reificação as diversas formas circunstanciais da comunicação. Por esta razão, em Ciência da Informação (assim como em outras ciências) a informação é frequentemente explicada colocando-se um "como" na frente do qualificador da circunstância comunicacional (a expressão "informação como conhecimento", por exemplo). Outra consequência dessa naturalização da informação é que esta se torna um

\footnotetext{
${ }^{60}$ Contudo, com a necessidade de um algoritmo produzido por humanos para iniciar e encerrar o processo de organização. Mas este pode ser suficientemente autônomo para interagir conosco.
} 
"fenômeno causativo" sem que se conheça realmente a fenomenologia de tal mecanismo causativo. Enfim, não há, sob essas perspectivas, uma compreensão da relação entre a informação e as diferenciações que ela gera. De fato, a diferença se torna um resultado (qualquer coisa apontada como tendo acontecido como informação), porém, sem uma conexão real com a informação (não é apontado como foi produzida a diferença que ensejou esse resultado), realimentando o processo de reificar o informar e o informar-se. Esse processo de continuamente justificar a informação através das coisas de que ela depende para acontecer não produz a compreensão que se necessita sobre como as diferenças são produzidas e se conectam para formar sistemas perceptivos, psíquicos, comunicacionais ou de qualquer outra ordem. Para alcançar tal compreensão seria necessário colocar a diferença no centro do conceito de informação.

Nesse sentido, a Teoria da Informação de Shannon pode fornecer a chave para essa compreensão. Mas não sem antes despi-la dos aspectos de engenharia que perfazem sua operacionalização enquanto comunicação, aspectos estes responsáveis pelo caráter "duro" da teoria, não afeito aos aspectos do significado e do sentido. Nessa reinterpretação, o que se deve destacar é a ênfase na informação como uma diferença entre sistemas (emissor e receptor, quando da operacionalização da comunicação), e o que se deve relativizar é a sua medida - mas não descartar completamente, como será argumentado mais adiante. É essa diferença que leva os sistemas à seleção, a arbitrar entre o que é relevante e irrelevante e então realizar uma escolha. $\mathrm{O}$ que é informação repousa inteiramente no grau de liberdade dessa escolha. Se a liberdade é total, ou seja, se é possível escolher o que é relevante tanto na fonte quanto no receptor, então o peso de cada escolha é indiferente e, assim sendo, informação será o grau máximo de escolhas que se pode fazer - daí decorre a noção de Shannon de informação enquanto cálculo da incerteza (ou seja, qual o número máximo de escolhas que se pode fazer entre fonte e receptor para viabilizar a comunicação; quanto mais escolhas possíveis, mais informação). No entanto, esse tipo de cálculo nada pode dizer sobre o significado ou o sentido porque cada escolha é neutra em si mesma, uma vez que é indiferente se realizada num sistema ou outro e, se este ou aquele não for acessível, esse cálculo se torna apenas um jogo de probabilidades. 
Quando, por outro lado, a liberdade de escolha é assimétrica, isto é, quando além de um dos sistemas não ser acessível também não for possível determinar ${ }^{61}$ se este é a fonte ou receptor (colocando quem seleciona também na condição de indeterminação), a escolha deixa de ser indiferente e passa a configurar uma orientação do sistema como um todo (a escolha é que vai dizer se este sistema se coloca na posição de emissor ou receptor). Nessa condição, a cegueira dos sistemas quanto à configuração das diferenças mútuas leva a um estado de tensão permanente em sistemas que precisam continuamente configurar seus estados relacionais (autoproduzir as estruturas de contato interno e externo). Contudo, essas diferenças não produzem sentidos a não ser que surja um espaço relacional de interações mútuas que coloque em xeque a autoprodução dos estados relacionais dos sistemas. Nessa segunda condição é que o surgimento de diferenças incitam à necessidade do sistema de se reorientar e que, tomando as palavras de Luhmann, podemos dizer que informação é uma diferença que obriga à seleção (LUHMANN, 2009). Esta seleção não é a seleção indiferente de Shannon, que pode livremente pinçar a diferença que quiser, contanto que esta some +1 , mas é a seleção de um estado relacional específico num sistema específico, ou seja, qualifica um dos pólos como emissor e outro como receptor, dotando o estado relacional de um peso específico, e assim de um sentido de observação. Portanto, a expressão "a informação como uma seleção de sentido", de Luhmann, deve ser tomada dentro desse contexto de um processo de continuação de qualificação de uma interação relacional específica dotada de um peso (um sentido) específico, e não como simplesmente a seleção de uma mensagem num processo de comunicação, o que está mais adequado dentro da concepção de Shannon de informação ${ }^{62}$.

Contudo, Luhmann não realiza uma contraposição à teoria de Shannon, pelo contrário, poderíamos dizer que ele adere a seus pressupostos principais, apenas pensando-os a partir de sistemas que, paradoxalmente, são fechados à informação do modo como Shannon a pensava (como a manipulação livre de diferenças entre dois sistemas dados). Luhmann pensa a informação como a possibilidade de trabalhar diferenças (e assim possibilitar a comunicação) a partir de sistemas autopoiéticos, os

\footnotetext{
${ }^{61}$ Um dado sistema pode estar funcionando num modo de "caixa preta" (que não revela como opera) e ainda assim pode ser possível determinar quando está sendo emissor ou receptor porque sua estrutura permite essa verificação, mas um indivíduo vivo não possui, obviamente, estruturas inequivocamente de entrada e saída.

${ }^{62} \mathrm{Na}$ ausência de uma explicação mais completa do raciocínio de Luhmann o uso do termo 'seleção' pode induzir à ideia de que o sentido é "algo pinçado" dentro de uma oferta de mensagens.
} 
quais produzem seus próprios estados diferenciados, tanto no sentido aferente quanto eferente e, portanto, impossibilitando a informação como uma permuta de estados (equalização das diferenças). A informação como seleção de sentido é, para Luhmann, uma consequência lógica dessa arquitetura, assim como a informação como seleção de mensagem é para Shannon uma consequência lógica da arquitetura aberta dos sistemas de engenharia.

A convergência entre os dois autores, nos postulados básicos, pode ser notada também quando abordam o que não é informação. Para Shannon, é simplesmente quando só se pode realizar apenas uma escolha num dado canal, frustrando assim qualquer incerteza e, portanto, novidade (a informação possível). Para Luhmann, igualmente, se não há novidade no que se está dizendo, não há informação. Mas enquanto que para Shannon essa ausência é devida a uma repetição do que se estava dizendo (redundância), para Luhmann não é uma simples questão de soma zero nas opções de seleção, porque mesmo a partir de uma mensagem repetida pode surgir uma seleção de sentido. Luhmann se coloca no lugar do observador, e este pode (por criar o ponto de vista) recolocar o que se repete numa situação de distinção não prevista (contextualização), enquanto Shannon trabalha com o historicamente subsequente.

O verdadeiro problema para Luhmann é quando esta distinção entra na comunicação e, portanto, pode ser considerada informação. A questão, para este autor, é quando uma distinção gera uma diferença na comunicação e, nesse aspecto, Luhmann é tão pragmático quanto Shannon: quando o que distinguimos é suficientemente diferente para gerar uma diferença que gere uma disputa de sentido. Por exemplo, enquanto dois indivíduos concordarem que determinado objeto tem uma cor $\mathrm{X}$ sem necessitar comunicar isso um ao outro (ou seja, manipulam ou coordenam o uso do objeto sem duvidarem que um e outro vêem a mesma cor), toda distinção possível da cor X desse objeto (mesmo que diferente de indivíduo para indivíduo) se encerrará como uma questão de percepção, mas se precisarem se comunicar para concordar ou discordar sobre essa cor X então surge uma disputa de sentido e, por consequência, informação (as diferentes seleções desse sentido). Os dois autores abordam a informação como uma diferença que precisa ser trabalhada pragmaticamente para existir, mas enquanto Shannon aborda a seleção como uma operação livre sobre diferenças já marcadas como unidades (mensagens), para Luhmann realizar uma seleção é uma operação que cria a 
realidade ao bifurcar (criar a diferença) entre o que se observa e o que não se observa, criando ao mesmo tempo a observação e o observador como uma disputa de sentido.

Observar é também, evidentemente, uma operação (de outra forma ela não ocorreria), mas uma operação altamente complexa que, ajudada por uma distinção, separa aquilo que ela não observa do que ela observa; e aquilo que ela não observa é sempre também a operação do próprio observar. A operação de observar é, nesse sentido, sua própria mancha cega que possibilita distinguir algo determinado e descrevê-lo. (LUHMANN, 2011, p. 155).

Toda seleção de sentido não é, portanto, livre ou indiferente, mas circunscrita como operação à diferença entre o que ela pode observar (a observação em si) e o que ela não pode observar (a operação de observar). Essa diferença se bifurca entre o que pode ser disputado (como seleções possíveis de sentido) e o que não se consegue disputar que fica marcado como percepção, ou seja, como não-informação ${ }^{63}$. Em outras palavras, aquilo que é apenas sinalizado não conforma uma disputa e, portanto, não pode entrar na conta informação, da qual não se pode cobrar exatidão para sua continuidade, sob pena de deixar de existir. Como afirma Luhmann, "a diferença entre sinalização e comunicação corresponde exatamente à exigência de não tornar a continuidade de uma comunicação para outra comunicação dependente do fato da informação ser completa e adequada" (LUHMANN, 2011, p. 157).

Seguindo no nosso exemplo anterior, se dois indivíduos apenas sinalizam um ao outro que o sinal no semáforo é vermelho estão assumindo uma mesma observação entre ambos, não há um informar-se mútuo, mas apenas um acoplamento na conduta (a percepção). Contudo, se a sinalização quanto à cor indicar diferenças, eles estarão assumindo mutuamente que um deles não é o observador (da cor real) e então a observação desacoplada induz a que selecionem a observação do outro como aquilo que não podem observar (a percepção da cor pelo outro). É nesse momento que a comunicação surge ${ }^{64}$, em que a impossibilidade de selecionarem um a percepção do

\footnotetext{
${ }^{63}$ Isto não significa que a percepção não utilize a informação para se formar, pelo contrário: justamente por serem muito vastas como operações de distinções, as percepções ficam em sua maior parte submersas e não selecionáveis pela comunicação. Essa questão será esclarecida quando abordarmos o conceito de informação integrada e dos níveis de atenção consciente. De qualquer forma, consideramos que quando nos referimos à percepção sempre o fazemos a partir do domínio da construção do sentido (como na interpelação "você percebe isto?"), ou seja, como disputa de sentido.

${ }^{64}$ Como diferenças que buscam uma margem de convivência, e não como uma congruência entre estados mentais (e seus signos e símbolos correspondentes) em comum. Isto se fundamenta em dois argumentos: primeiro, que nunca se chega (ou se pode saber) o quanto existe de comum num processo de comunicação, portanto, se a comunicação fosse baseada nesse conhecimento estaria, na verdade, se
} 
outro diretamente obriga que seja selecionado um sentido de orientação na interação (a qualificação "o outro está vendo vermelho" ou "o outro está vendo verde"). Ao contrário da seleção de Shannon, que assumiria as possibilidades vermelho/verde como uma diferença no número de mensagens possíveis, uma seleção de sentido precisa se preocupar com a natureza da interação para alcançar a compreensão (sendo esta a dissolução da disputa de sentido). Essa preocupação não tem relação com a justeza da sinalização (se o sinal de semáforo está realmente verde ou vermelho), mas em que nível de qualificação mútua cada seleção de sentido ocorre: se estamos selecionando um sentido que ocorre internamente (psíquico) ou um sentido derivado de seleções coletivas (um sentido social).

Se a seleção de sentido é de consciência (cada um seleciona o que pensa que o outro está vendo), apenas uma grande diferença na conduta coordenada (a percepção) levaria a um fracasso a compreensão (por exemplo, se um deles for daltônico e declarar como verde o que o outro está vendo como vermelho). Mas essa sinalização é totalmente dependente da interação, ela não precisa ser completa e nem perfeita para haver seleção de sentido (informação): se os dois indivíduos estiverem em carros separados coordenarão uma compreensão convergente (pela posição do sinal luminoso), apesar de suas seleções de sentido serem frontalmente distintas ${ }^{65}$. Por outro lado, essa compreensão só foi possível porque operou outro tipo de seleção de sentido, de alcance muito mais largo porque é feita de sucessivas e reiteradas seleções de consciência que selecionou o vermelho como um sinal de perigo, e a posição mais alta como mais privilegiada, portanto, mais adequada para um sinal de alerta. Fossem essas seleções de consciência orquestradas por outra coletividade, sob outras condições não só de interação como também sobre outro background de seleções sociais, talvez o vermelho sinalizasse "avance!" e a posição inferior como privilegiada (ou vice-versa), com outras consequências para a compreensão (e para a comunicação).

\footnotetext{
baseando no que lhe falta saber, o que é, ao final, como argumentamos um operar através da diferença; e segundo, se hipoteticamente esses estados mentais em comum (e suas representações) alcançassem uma equivalência perfeita - ou muito próxima disso - não haveria razão para se começar qualquer comunicação (como vimos antes e veremos mais adiante, este segundo argumento se aproxima do conceito de percepção).

65 Outros modos de interação (por proximidade) poderiam igualmente conduzir a uma compreensão, como o conhecimento prévio de uma percepção invertida no outro (daltonismo), ou uma atribuição vaga de erro ao perceber a cor baseado em que foi sinalizada corretamente a posição - o que deve ser notado é que o que comanda a seleção de sentido é o modo de interação (o tempo e a disposição relacional envolvidos na coordenação) e não o que está sendo sinalizado (a cor e a posição do sinal de semáforo). Se mudar a interação, muda a atribuição e vice-versa.
} 
O que precisa ser retido do exemplo acima é que a seleção de sentido, por ser uma operação que se baseia na escala disponível na interação, constrói os próprios sistemas de que se serve (eles não existem independentemente ou a priori). Essa construção se divide em duas (como já adiantamos algumas vezes): em sistemas psíquicos e sistemas sociais, através do que é separado como admissível e não admissível na constituição dos mesmos, a saber, como a separação entre percepção e informação no caso dos sistemas psíquicos, e como a separação entre informação nova e não-informação (ou informação velha, desvalorizada ${ }^{66}$ ) no caso dos sistemas sociais (que são, enfim, os sistemas onde acontece a comunicação de fato). Note-se que não importa (substancialmente), nesta pesquisa, o que sustenta estruturalmente cada sistema (em termos das propriedades biológicas de cada operação psíquica ou das características que estabelecem as diferenças entre meios de comunicação de massa e individuais), mas como estes sistemas são construídos enquanto seleções de sentido, por isso a preocupação central é em relação aos regimes de interação que acoplam esses dois sistemas para a construção holística do sentido (admitindo-se aqui a tese de que não existe atividade psíquica pura ou atividade social desvinculada de interações psíquicas). Contudo, se o sentido de algo é holístico em si (não podemos separar em definitivo seus componentes psíquicos e sociais), como o valor de se apreciar um balé ou a fragrância de uma rosa, pode-se separar dos sistemas envolvidos pelos regimes de interação que conformam a informação disponível. Para isso, entretanto, precisamos primeiro ter bem claro os modos de seleção envolvidos, a saber, os de seleção de sentido e os de seleção de mensagem.

Se toda a situação do exemplo anterior fosse vista pela seleção de mensagem, seria vista como unidades discerníveis já prontas, passíveis de serem selecionadas como

\footnotetext{
66 Os exemplos de Luhmann a respeito são principalmente (mas não exclusivamente) retirados da preocupação do autor com os meios de comunicação de massa.

"Sua preferência [dos meios de comunicação de massa] por informação, que perde seu valor de surpresa no momento em que se torna pública, isto é, em que é continuamente transformada em não informação, deixa claro que a função dos meios de comunicação consiste na produção contínua e no processamento das irritações - e não no aumento do conhecimento, nem numa socialização ou educação no sentido da conformidade às normas. Como efeito real dessa atividade contínua circular de produzir e interpretar as irritações por meio de informações vinculadas a um momento particular (quer dizer, como diferença que faz a diferença) surgem as descrições do mundo e da sociedade pelas quais se orienta a sociedade moderna dentro e fora do sistema de seus meios de comunicação. [...] Não se pode, naturalmente, supor que a irritação só apareça no sistema dos meios de comunicação e não apareça, por exemplo, em casamentos, em aulas escolares ou em outras interações; da mesma forma, o poder não aparece somente no sistema político, as normatizações apenas no sistema jurídico, a verdade no sistema científico. A irritabilidade é a característica estrutural mais geral dos sistemas autopoiéticos; ela assume, na descrição moderna, o lugar que se atribuía no passado à natureza ou à essência das coisas definida como natureza". (LUHMANN, 2011, p. 159).
} 
unidades de sentido ou significado conformando possíveis mensagens - e nenhuma preocupação se estas têm uma natureza perceptiva, psíquica ou social. Se essa abordagem confunde frequentemente sentido e significado ${ }^{67}$, tornando impossível saber se uma dada mensagem selecionada será usada no contexto $x$ ou $y$, por outro lado, a seleção de mensagem parece ser a primeira que reconhecemos (senão a única, em alguns casos) quando se trata de reconhecer a informação e torná-la disponível (como a TI - Tecnologia da Informação - o demonstra profusamente). Como explicar este paradoxo?

Em primeiro lugar é preciso detalhar sobre o que estamos falando quando nos referimos à expressão "seleção de mensagem". Não se trata apenas do conceito de Shannon, que tratou desse modo em sua forma mais precisa, mas da consideração mais geral e difusa de que se selecionamos algo em $A$ podemos fazê-lo também em $B$. Essa consideração também estipula que só se pode selecionar algo como mensagem se esta mantiver sua unidade quando for selecionada de novo, isto é, que se reproduzirá de algum modo no receptor destinado. Estas considerações projetadas não estão apenas na Teoria da Informação (onde assumem literalmente uma preocupação com a reprodução do que é selecionado), mas é antecedida - em muito - pelo senso comum, que assume que se uma mensagem for construída para manter uma unidade representacional (uma relação de representação com coisas, fatos ou eventos no mundo) ela fatalmente se reproduzirá (será selecionada) por quem a ela se destina. Essa desconsideração ao modo como uma mensagem pode vir a ser descontruída pela seleção de contextos concorrentes (ou seja, pela seleção de sentidos concorrentes) não é apenas um exercício teórico, mas é cotidianamente adotada como um modo de acoplamento social na comunicação. Pessoas, em seu cotidiano, estão continuamente assumindo que aquilo que selecionam como uma mensagem será tranquilamente reproduzido por aqueles a quem a mensagem se destina. Isso tanto em relação a mensagens previsíveis, como as que declaram fatos perceptivos (“a grama é verde”), como em relação a mensagens mais elaboradas ou mesmo controvertidas ("o aquecimento global é uma farsa"). Embora essa postura possa causar até mesmo tragédias (quando o sentido da mensagem é

\footnotetext{
${ }^{67}$ Provisoriamente (mais adiante abordaremos essa distinção do ponto de vista sistêmico), distinguiremos significado como uma atribuição de sentido afastada (ou deslocada) de seu contexto original, e sentido como a qualificação, contextualmente marcada, de uma experiência. Por exemplo, podemos atribuir, como ocidentais, muitos significados à cerimônia japonesa do chá, sem nunca realmente compreendermos seu sentido. Do ponto de vista da seleção de mensagem organizar os significados seria equivalente a recuperar o sentido.
} 
violentamente disputado), na maioria das vezes, e na maior parte do tempo, ela funciona bem e pode ser considerada um dos fundamentos da vida social (por dispor continuamente de um background à coordenação social), e ajuda a entender porque a noção de representação é geralmente aceita (no senso comum) como natural e verdadeira. De fato, antes de vir a ser elaborada teoricamente, a noção de representação já deveria existir circunstancialmente através do modo de seleção de mensagem, e a elaboração de uma explicação para a representação a partir de uma relação de verdade entre as proposições e o mundo é posterior ao modo de seleção de mensagem, talvez contemporâneo ao surgimento do termo representação "como o ato de estar no lugar de".

A despeito de qualquer crítica à noção de representação como explicativa, porém, é preciso considerar a importância fenomenológica do modo de seleção de mensagem para separá-la não apenas das tentativas de explicá-la através do viés representacionista, mas também para distingui-la corretamente da seleção de sentido como modo de criar informação. Para tanto, vamos retomar nossa discussão do ponto onde analisávamos como a seleção de sentido surge a partir da impossibilidade de dois sistemas observantes, por se constituírem como observadores como sistemas autodeterminados, de conhecerem mutuamente os estados internos de informação um do outro. Essa impossibilidade deixa apenas um caminho para os sistemas observantes: selecionar qualquer diferença entre ambos, ou entre si próprios e o meio, como um sentido que o próprio sistema toma em relação ao ato de diferenciar a si mesmo do outro ou do meio. Nessa operação ainda não há margem para a seleção de mensagem porque o sistema ainda está ocupado em separar a si mesmo daquilo que distingue, ou seja, de qualificar uma experiência como uma terceira diferença (entre si e o outro, entre si e o mundo, ou numa relação triangulada entre estes). Apenas após uma seleção de sentido entrar em relação como outra, no qual a qualificação de uma experiência qualifica por sua vez a qualificação de outra (ou a mesma) experiência (tecendo assim uma rede contextual), é que se teria a condição mínima para uma codificação dual e, portanto, de uma atribuição mínima de mensagem a algo distinguido na experiência. Isto implica, portanto, que a seleção de mensagem aparece apenas secundariamente, no entanto, isto não implica numa relação hierárquica, de que seja um processo inferior, de secundidade. Pelo contrário, trata-se de uma emergência sistêmica diferenciada permitida por uma complexidade que alcançou um ponto crítico no qual as diferenças 
em tensão dão origem a um processo novo, não presente e nem mesmo imanente ao sistema anterior.

Mas qual seria a origem desse processo novo? Esta pode ser buscada no obscurecimento refratário causado pela complexidade do sistema do qual emerge. Como afirmamos antes, a seleção de sentido se origina, e dá origem, a dois sistemas principais: o psíquico e o social através de um processo que define quando há informação em jogo (como diferenças em disputa) e quando estas passam a ser outra coisa (percepções ou consensos sociais). Aquilo que passa a ser outra coisa não se trata de algo descartado ou trivial, mas de algo que continua a ser processado no sistema e, todavia, fora de sincronia com contextos específicos que a transforme em disputa de sentido (informação). Esta complexidade (tudo que foi processado como sendo a diferença entre sistema e meio) é justamente aquilo que o observador não pode observar: a própria observação. Isto é, a seleção de sentido, para ser seleção de sentido, só pode lidar com aquilo que constrói relacionalmente a observação, deixando fora de foco (numa zona cega) aquilo que sustenta o ato de observar. Luhmann dá o exemplo da relação entre irrigação do sangue e pensamento, a primeira é fundamental para o segundo existir, mas ninguém fica pensando em quanto de sangue precisará para elaborar o próximo pensamento. De modo análogo, para se fazer uma seleção de sentido não é necessário estar a par de toda a cadeia complexa de distinções que a perfaz. Ou seja, quando observamos uma cena qualquer, como duas pessoas falando, e a qualificamos como engraçada, séria ou absurda, não observamos (e nem conseguiríamos) como a cena foi construída - ela está, para todos os efeitos, dada.

A partir desta primeira sensação, de que toda observação se realiza sobre um mundo já dado, é que a seleção de mensagem nasce, embrionariamente, como um modo de trabalhar a diferença a partir de distinções já presentes, e o seu ordenamento como modo será a partir dessa limitação à observação. Desta forma, o observador só surge como falha, como aquele que, ao intervir, provoca uma interrupção num fluxo de coisas já dadas, porque essa intervenção é posterior, não natural, portanto, uma interpretação de um processo natural. E por ser uma cunha a cindir a realidade dada, o observador não existe como tal (como aquele que cria dinamicamente o que observa), mas como um ponto fixo em relação ao fluir dos dados naturais, isto é, um sujeito ${ }^{68}$, algo que precisa

\footnotetext{
${ }^{68}$ Existem, no pensamento moderno e pós-moderno, muitas críticas à noção de sujeito e, por isso, muitas reformulações relativizantes nas quais o sujeito pode aparecer como um ente criativo e criador do mundo
} 
se justificar enquanto às interferências que realiza na realidade através das referencias que é capaz de fazer entre o ponto de clivagem $A$ e o ponto de clivagem $B$.

Nesse ordenamento, no qual o observador some para dar lugar apenas à observação como algo já dado (ou do qual extraímos dados), apenas sobra o sujeito como aquele que acumula interpretações que precisam se justificar continuamente como percepções (como referências adequadas aos dados da realidade). Nesse contexto, o modo de operar, isto é, seu regime, está comprometido pelo que se pode conservar de $A$ e de $B$ entre uma intervenção e outra, isto é, entre uma diluição das fronteiras entre $A$ e $B$ (sua "subjetivação") e a conservação destas bem definidas. Este comprometimento acarreta a que se trate a complexidade do que é observado como algo a ser reduzido, toda vez que a distinção entre $A$ e $B$ precisar ser distinguida novamente como bem definida. A redução da complexidade é a base operacional da seleção de mensagem como operação de distinção de diferenças e é o que a marca como regime de informação. Apesar de pressupostos representacionistas terem sido invocados para explicar a formulação de mensagens como representações válidas do mundo, de fato, este pressuposto não é necessário para as mensagens funcionarem coerentemente no seio da comunicação social. Além de a própria Lógica demonstrar que seus silogismos funcionam perfeitamente sem precisar apelar para razões metafísicas para executar uma formulação coerente do enunciado $A$ em relação ao enunciado $B$, no próprio cotidiano da comunicação essa coerência é um requisito para se aceitar ou não uma oferta de mensagem (apesar de os requisitos não serem, frequentemente, baseados na Lógica, mas em convenções sociais).

O pressuposto subtraído dessa coerência, contudo, costuma ser tão controvertido quanto a noção de representação: a de que a comunicação é coerente porque as mensagens distinguidas conformam unidades ou de sentido, ou de significado, ou de conhecimento, baseada esta unidade numa certa comunhão mental de sentido ou significados que permitiria a transmissão das mensagens. Todavia, como explicar essa comunhão? Além das antigas concessões à noção de representação, de que essa comunhão é obtida mediante certa homogeneidade das "representações mentais",69, até

que o cerca, mas defendemos nesta pesquisa que, se este ainda é assumido como um interprete subjetivo (que mais cedo ou mais tarde precisa justificar suas referências), então estas relativizações se tornam estéreis no intuito de conceituar o sujeito como observador.

${ }^{69}$ Por esse tipo de representação nos referimos ao mais restrito senso dado ao termo, a de que a percepção precede e molda a informação que conseguimos do exterior, portanto, a subjetividade está restrita (pelo 
tem se lançado mão de teses mais sofisticadas, como a do meme $e^{70}$. Contudo, ambas as abordagens resvalam no problema da natureza mutável da cultura e da comunicação, como afirma James Gleick, “[...] a maioria dos elementos culturais muda e se obscurece com demasiada facilidade para que possam ser classificados como replicadores estáveis" (GLEICK, 2012, p. 330). Ambas as abordagens, a de "representação mental" e a de meme, apesar de suas origens teóricas distintas, são modeladas como seleções de mensagem, isto é, como algo externo ao observador que se repete neste de algum modo, independente das determinações sistêmicas da observação, sejam psíquicas ou sociais.

Em nossa abordagem, por outro lado, o regime reducionista da seleção de mensagem tem sua razão de ser na própria construção do sentido através do acoplamento entre sistema psíquico e sistema social - sendo este acoplamento a razão para a cegueira quanto às determinações sistêmicas daquilo que se observa. Para entender isto, primeiramente será necessário conhecer o que a estruturação do sistema psíquico oferece à seleção do sistema social, tanto em termos de retroalimentação mútua quanto de desequilíbrios que levam a uma assimetria criativa que tem como consequência a construção do sentido.

\subsubsection{Sistemas psiquicos e sociais na geração da seleção de sentido}

Na concepção de Luhmann, sistemas psíquicos se compõem através de "seleções de consciência", por uma diferença entre sistema (todas as operações de distinção de que o pensamento é capaz ${ }^{71}$ ) e o meio (o que é produzido como "percepções" ${ }^{\text {"72 }}$ ), mas

menos a sã) a um jogo com elementos estáveis obtidos do meio natural pela percepção, elementos esses que permitem um repertório de representações em comum que viabilizam a "intersubjetividade".

${ }^{70}$ Memes seriam a versão cultural dos genes, e da mesma maneira como estes últimos "carregam informação" de uma forma organizada no meio biológico, memes também carregariam informações de uma mensagem específica, e assim como os genes lutam para ver vencer sua herança biológica os memes lutariam para triunfar como ideia, costume, crença ou hábito no interior de uma cultura ou até mesmo fora dela, em outras (e por isso seriam evolutivamente superiores ao genes, que estão encerrados à própria espécie, no entendimento Richard Dawkins, que teorizou sobre os memes ao fim de seu tratado $O$ gene egoísta).

${ }^{71}$ Javier Torres Nafarrate, editor de uma das obras de Luhmann (2009), apresenta o seguinte comentário desse autor: "fala-se em atos de percepção, pensamento, sensibilidade, vontade, como diferentes capacidades da consciência, deixando-se em aberto o problema da unidade de operação da consciência. Certamente, tal unidade consiste em um processamento da atenção; mas, qual o termo que deveria ser escolhido para descrever isso? [...]" (LUHMANN, N. Die autopoiesis des bewusstseins. In: Soziologische Aufklárung, 6. Opladen, 1995, p.55ss). Segundo Nafarrate, os elementos dos sistemas psíquicos, em Luhmann, como pensamentos ou representação, seriam apresentados como tendo uma duração fugaz, momentânea, ou seja, teriam o caráter de acontecimentos (ver LUHMANN, 2009, p. 271, nota 2). 
esse percurso não fica muito claro, especialmente quando pensamos no termo "consciência" e na problemática da escala das escolhas ou seleções de sentido, se estas seriam conscientes ou inconscientes. Existe também a questão de que sistemas psíquicos e sociais selecionam num mesmo meio:

Tanto os sistemas psíquicos, como os sociais, operam dentro do sentido, o que permite efetuar suas operações respectivas em um meio análogo, embora isso não signifique que consciência e comunicação reproduzem o mesmo tipo de operação. A afirmação de que tanto a consciência como a comunicação operam dentro do sentido não tem senão a intenção de apontar que esses sistemas operam em um meio de excedentes de possibilidades, pelo qual se obrigam a realizar processos de escolha, na medida em que focalizam o atual e deixam de lado outras possibilidades. (LUHMANN, 2009, p. 259).

Portanto, a construção do sentido, para ser entendida, necessita que se esclareça qual o modo de seleção desses excedentes por cada tipo de operação (de consciência ou social), o que ajuda a entender, também, a natureza desses excedentes (uma vez que o sentido é multiplicado, pelo seu lado, por seleções que produzem bifurcações crescentes). Nesse sentido, há um autor da área de neurociência, Giulio Tononi, que pode esclarecer não só o percurso informação $\rightarrow$ consciência, evitando as armadilhas da descrição da consciência apenas em termos de estados conscientes/inconscientes (o que levaria o tema para um viés psicologizante) como também descrever o modo como a informação é configurada enquanto tratamento de distinções num sistema psíquico. A abordagem teórica e metodológica de Tononi também traz a vantagem, em acordo com as premissas desta pesquisa, de inverter o esquema representação $\rightarrow$ informação (no qual a primeira ganha uma veracidade ontológica) para o diagrama informação $\rightarrow$ representação (no qual esta última é apenas a seleção de um enunciado representativo). $\mathrm{O}$ esquema representação $\rightarrow$ informação sustenta a abordagem representacionista da mente, e pode ser constatado inclusive em pesquisas destinadas a questionar as abordagens clássicas e hierárquicas da cognição, como nos primeiros trabalhos de Rosch:

\footnotetext{
${ }^{72} \mathrm{O}$ meio, para um Sistema operacionalmente fechado, é aquilo a que ele pertence como produto de sua operação e não pode ser observado, muito menos usado, por outros sistemas quando em acoplamento: “o processo comunicacional não pode estabelecer conexão imediata com a percepção: o que o outro percebeu não pode ser negado, nem confirmado, tampouco questionado, ou rechaçado. A percepção permanece subjugada no fechamento da consciência, e é totalmente invisível tanto para o sistema de comunicação como para a consciência dos outros" (LUHMANN, 2009, p. 298).
} 
Quando ouvimos o nome de uma categoria, que tipo de representações cognitivas a mente humana gera: uma lista de características válidas, uma imagem, ou algo mais? Esta questão faz parte de outra mais geral, de como categorias e conceitos são codificados na memória e como estes são usados no processo da informação. ${ }^{73}$ (ROSCH, 1975b, p. 306, grifo nosso, tradução nossa).

Tononi afirma (2008) que a existência da consciência se deve a um processo de integrar um número crítico de estados discriminatórios até que todos estes induzam à criação de um ponto de vista que gere uma experiência. Estes estados discriminatórios, como "a habilidade de discriminar entre um grande número de alternativas" (TONONI, 2008, p. 218), são, em princípio, o que chamamos de informação, mas apenas se cada discriminação for indiferente uma em relação à outra. Como exemplifica Tononi, um chip composto por milhões de fotodiodos pode realizar igual número de discriminações por segundo e assim verificar a existência de luz numa sala, sua intensidade, etc., mas não é capaz de ter a experiência da luz porque estes fotodiodos não interagem entre si para integrar esses milhões de estados discriminatórios - estes permanecem isolados.

Em resumo, a única coisa que um fotodiodo pode fazer é especificar se as coisas são deste ou daquele jeito: qualquer especificação além dessa é impossível porque não há um mecanismo para tanto. Portanto, quando um fotodiodo detecta "luz", tal "luz" possivelmente não significa aquilo que significa para nós; nem mesmo que possa ser um atributo visual. Em contraste, quando nós enxergamos a luz conscientemente, estamos sendo implicitamente muito mais específicos: simultaneamente especificamos algo como estando melhor de um modo do que de outro (o iluminado como oposto à escuridão), que se seja o que for que nós discriminamos não é colorido (em qualquer cor em particular), que não possui forma (em relação a qualquer forma em particular), e que é visual em oposição ao que é auditivo ou olfativo, sensorial como oposto ao que é presumido, e assim por diante. Para nós, então, a luz possui muito mais significado precisamente porque possuímos mecanismos que podem discriminar esse estado particular de acontecimentos que chamamos de "luz" contra um grande número de alternativas. ${ }^{74}$ (TONONI, 2008, p. 218, tradução nossa).

\footnotetext{
${ }^{73}$ When hearing a category name, what sort of cognitive representation does the human mind generate: a list of criterial features, an image, or something else? This question is part of the general issue of how categories and concepts are coded in memory and how they are used in the processing of information. (ROSH, 1975b, p. 306).

${ }^{74}$ In short, the only specification a photodiode can make is whether things are this or that way: any further specification is impossible because it does not have mechanism for it. Therefore, when the photodiode detects "light", such "light" cannot possibly mean what it means for us; it does not even mean that is a visual attribute. By contrast, when we see "light" in full consciousness, we are much more specific: we simultaneously specify that things are this way rather than that way (light as opposed to dark), that whatever we are discriminating is not colored (in any particular color), does not have a shape (any particular one), is visual as opposed to auditory or olfactory, sensory as opposed to thought-like, and so on. To us, then, light is much more meaningful precisely because we have mechanisms that can
} 
Na análise de Tononi, a consciência é fenomenologicamente um todo integrado, que perde sentido ao ser examinado em partes, e, por esta razão, um

[...] sistema físico ${ }^{75}$ precisa ser capaz de discriminar entre grandes repertórios de estados (informação) e de forma unificada; realizado isto, é como se o estivesse fazendo como um único sistema, um que não pode ser decomposto em numa coleção casual de partes [...]. ${ }^{76}$ (TONONI, 2008, p. 219, grifos nossos, tradução nossa).

O ponto central dessa abordagem (IIT - Integrated Informational Theory) é como a integração da informação gera a experiência e a seleção desta pela consciência (ponto de vista) enquanto sistema. A princípio, o sistema pode ser visto, em seu nível mais básico, como um mecanismo na teoria de Shannon em que um estado particular qualquer pode ser medido pela entropia relativa $H$ entre um repertorio real e outro potencial (como os picos de disparo num neurônio entre um estado e outro). Mas tudo começa a mudar de figura quando se passa a considerar a integração dessa informação. Primeiro, o sistema precisa estar fechado a "inputs" externos, tratados então como "ruído", porque cada repertório real será especificado por cada parte do sistema como interações causais internas (TONONI, 2008, p. 220). E claramente, para esta informação integrada ser alta (simbolizada por $\Phi$ ), o sistema precisa estar interconectado de tal forma que a informação gerada entre suas partes seja maior que aquela gerada internamente em cada parte, assim, tal sistema só poderá gerar informação integrada na mesma extensão em que não poderá ser decomposto em unidades informacionais separadas (TONONI, 2008, p. 221). Enquanto mera matematização da atividade do cérebro, a informação integrada pode não dizer muita coisa sobre o significado, mas quando esta divisa que a quantidade de informação integrada acima e além de suas partes integrantes gera complexos que começam a especificar uma direção na interação (um "ponto de vista", ver setas na figura 1, abaixo), a abordagem começa a apontar a emergência da consciência a partir da geração de uma grande quantidade de repertórios de escolha.

discriminate this particular state of affairs we call "light" against large number of alternatives. (TONONI, 2008, p. 218).

${ }^{75}$ Esse sistema pode ser inclusive artificial ou uma simulação, mas em relação à complexidade da geração de uma experiência consciente apenas o cérebro tem condições de disparar informações integradas.

${ }^{76}$ A physical system must able to discriminate among a large repertoire of states (information) and it must be unified; that is, it should be doing so as a single system, one that is not decomposable into a collection of causally independent parts [...]. (TONONI, 2008, p. 219). 


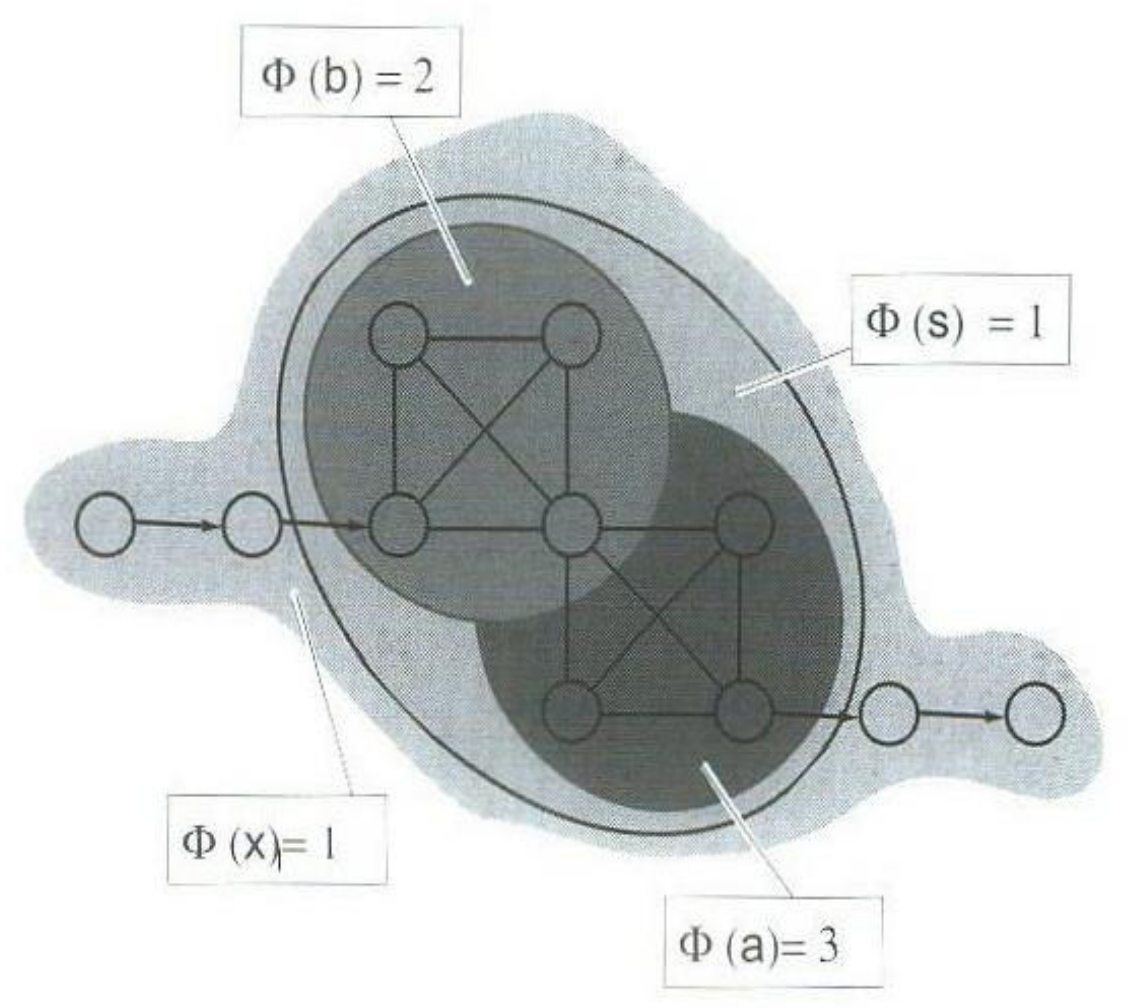

Figura 1 - Complexos

Fonte: TONONI, 2008, p. 224.

Como afirma Tononi, se a quantidade de informação integrada provê a quantidade de consciência gerada, o conjunto de todos os relacionamentos informacionais que o cérebro gera é o responsável pela qualidade da consciência emergente; ou seja, o como a informação se integra é que determina não só a quantidade de consciência, mas também principalmente que tipo de consciência (TONONI, 2008, p. 224). Isto se traduz em que, ao considerar uma discriminação simples como "luz", na verdade esta não é nada simples, pois não se trata apenas "pinçar" algo em meio ao todo o resto (uma seleção indiferenciada), mas é uma distinção realizada de um golpe só, de um modo muito específico, entre cada e todas as alternativas possíveis. Assim, definimos que a luz é o que é em virtude de ser diferente, de uma maneira muito específica, a partir de qualquer alternativa possível - desde as alternativas possíveis de 
escuridão, ou de qualquer tipo de cor, ou qualquer tipo de forma, ou qualquer som, cheiro e assim por diante (TONONI, 2008, p. 224). Em outras palavras, para "percebermos" até a mais simples das entidades, é necessária uma astronômica quantidade de discriminações (seleções) em rede, permitida por um conjunto altamente estruturado de mecanismos neurais.

Essas condições indicam, para Tononi, que uma grande quantidade de repertórios de escolha não basta para explicar a consciência, que é preciso que estes repertórios sejam integrados num relacionamento informacional que total e univocamente qualifiquem a experiência - diríamos que a própria experiência não seria percebida se não fosse qualificada como tal, sendo esta, portanto, a essência da consciência (transformar a distinção de algo numa experiência através da qualificação da relação entre as alternativas distinguidas que perfazem esse algo). Desta perspectiva, portanto, não é possível existir algo como experiências independentes, baseadas em percepções puras, por cima das quais acrescento minha subjetividade para colori-las com uma qualidade. A toda experiência corresponderia um qualia, isto é, uma correlação entre distinções que privilegia um relacionamento específico entre estas, logo, uma forma - dando vazão à percepção de algo.

Não existindo, então, experiência independente da capacidade de distinção, não existe a percepção como a apreensão de formas pré-existentes, toda forma precisa ser construída pela distinção e as diferenças potenciais que esta desdobra (ou seja, precisa primeiro ser informação). Em contrapartida, esse raciocínio implica que toda distinção não pode ser dissociada de uma forma. Lembramos, mais uma vez, que para Luhmann, distinguir é draw a distinction (desenhar uma distinção), ou toda forma é uma distinção e toda distinção uma forma de separação, de marcar tudo em duas partes, sendo a forma, portanto, uma linha fronteiriça que marca uma diferença (LUHMANN, 2009, p. 86). Para Tononi, no entanto, essa forma ganha certa literalidade como uma geometrização da informação no cérebro, quando são realizadas conexões entre complexos de informação integrada que se afastam de uma distribuição uniforme de possibilidades (TONONI, 2008, p. 227). Na figura abaixo, essas conexões são como enflechamentos que direcionam geometricamente uma distribuição ( $q$-flechas - q-arrows - , as setas em negrito que apontam a direção da forma) que acaba tomando uma forma com uma qualidade espacial específica, a qual representa um relacionamento informacional entre possibilidades na base do repertório de escolhas. 


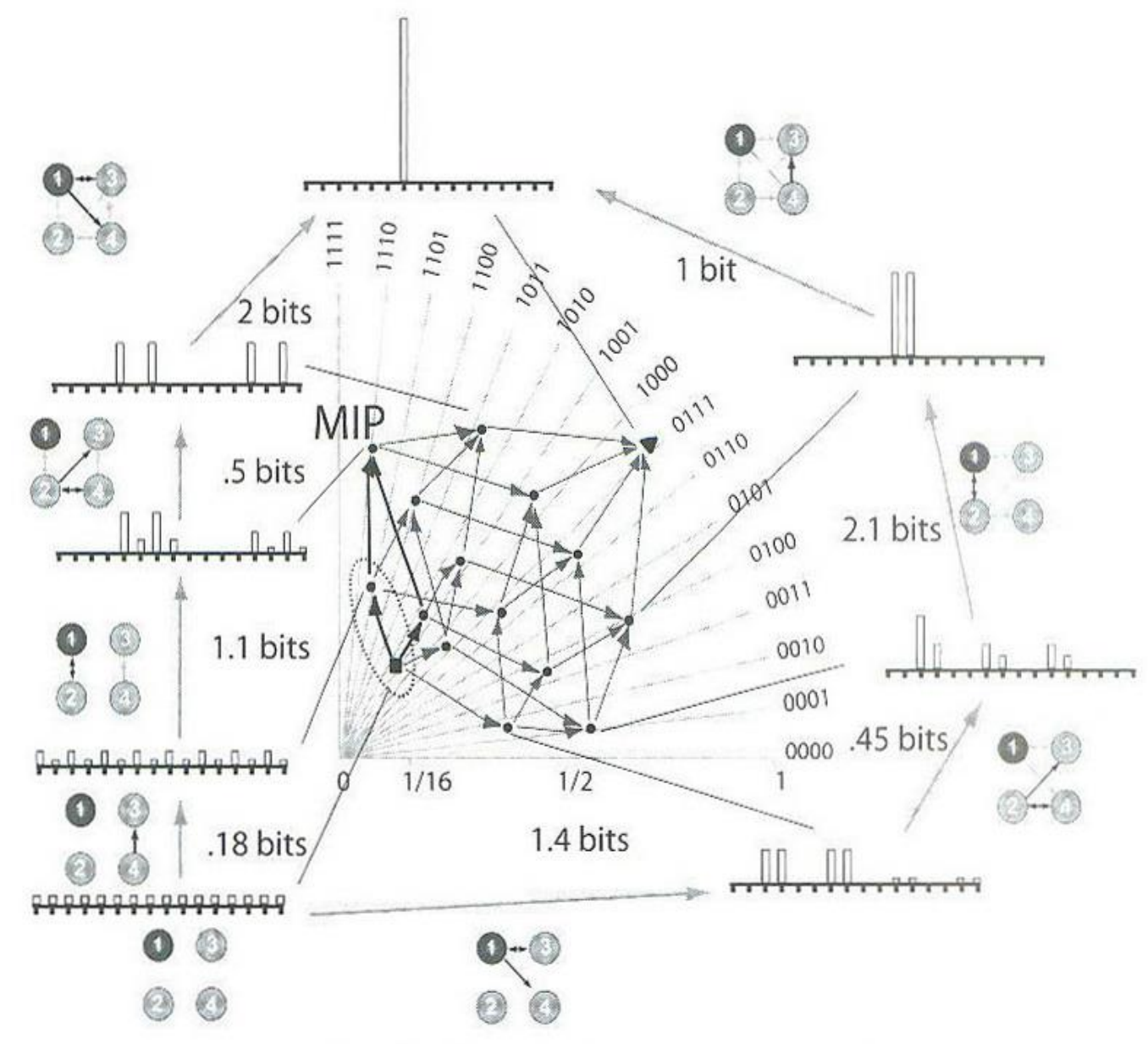

Figura 2-Qualia

Fonte: TONONI, 2008, p. 226.

O mais importante a se destacar é que esse qualia-espaço possui propriedades específicas, não no sentido de algo intrínseco ou extrínseco, mas provenientes do comportamento informacional emergente da integração entre complexos, o qual redunda num modo específico de se tratar a diferença. Esse modo pode ser identificado nas propriedades principais necessárias no surgimento do qualia-espaço: relacionamentos contexto-dependentes e emaranhamento (entanglement). Por contextodependente aqui se deve entender uma convergência de possibilidades de relacionamentos informacionais que forçam uma projeção que "arma" a forma, possibilitando o próprio qualia, ou seja, uma experiência tridimensional com profundidade, na mente. Veja-se na figura seguinte que ausência de contexto apenas permite o desenho de um relacionamento informacional raso (a seta entre os elementos 3 e 4), incapaz de subir à condição de experiência (ou seja, de profundidade 
tridimensional), sendo esta, por outro lado, granjeada pela interconexão entre os elementos 3,4 e 2 .

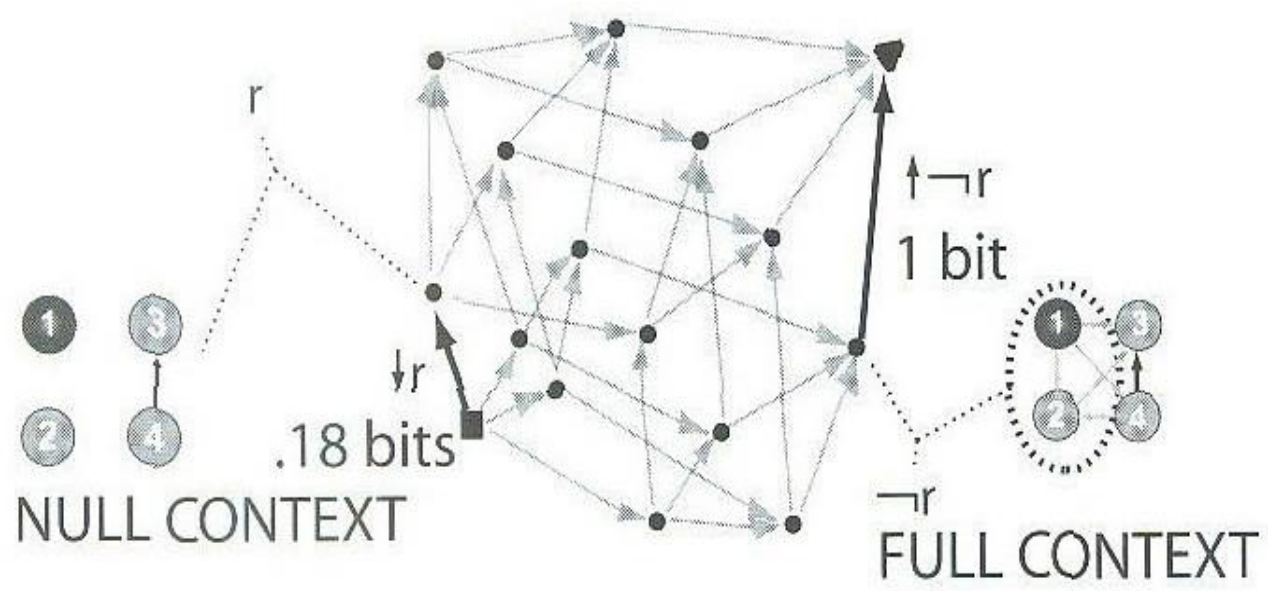

Figura 3 - Propriedades contexto-dependentes

Fonte: TONONI, 2008, p. 228.

Como o exemplo ilustrado acima é uma modelagem das mais simples, na verdade, simples demais para ser correlacionada à menor das experiências possíveis, é lícito supor que não é possível existir pensamento sem contextualização, uma vez que a menor das experiências requer a concorrência de uma miríade de alternativas na especificação de um relacionamento que conforme essa experiência. Portanto, experiências puras, isoladas, "auto-evidentes", e as idealizações que as acompanham, como as "categorias puras", como o "vermelho puro", ou a ideia de conceitos como unidades independentes não poderiam ser contemplados como articulações informacionais nos sistemas psíquicos, apenas como referências a estados fundamentais hipotéticos, e sua articulação deve ser buscada em outro sistema. Contudo, antes dessa busca, é preciso entender como os sistemas psíquicos dão formas distintivas à experiência (em outras palavras, "categorizam" a experiência). A propriedade que permite ao qualia-espaço se desdobrar em formas distintivas, e ultrapassar a tendência a uma distribuição uniforme da informação (entropia), é o emaranhamento entre os relacionamentos ( $q$-flechas) que especificam um ou mais tipos de relacionar repertórios de escolhas (complexos) (TONONI, 2008, p. 227). Assim como informação integrada é, 
segundo Tononi, mais que a soma das partes que perfazem um complexo de escolhas, o emaranhamento caracteriza relacionamentos informacionais ( $q$-flechas) que são mais do que a soma destes como componentes relacionais. Geometricamente, isso se traduz como uma torção no qualia-espaço que direciona todos os $q$-flechas para o topo da forma, proporcionando uma experiência altamente contextualizada (na figura abaixo o pequeno triângulo no topo da forma). Essa torção é produto da distribuição das interdependências entre relacionamentos informacionais ( $q$-flechas em negrito, no lado esquerdo da figura abaixo) cujo emaranhamento nunca é simétrico, mas uma construção tensa (a seta em zig-zag à direita na figura).
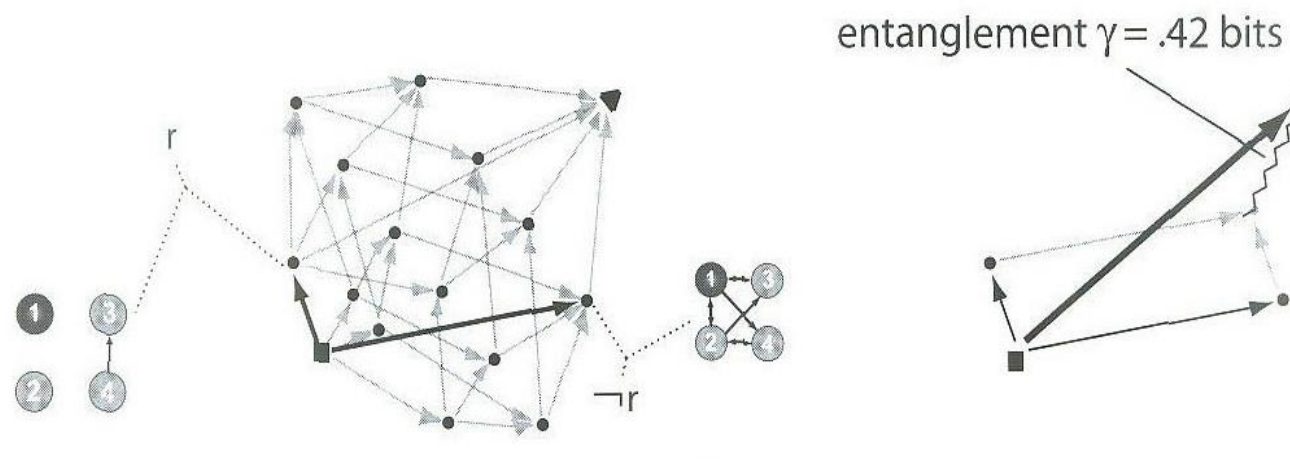

Figura 4 - Emaranhamento

Fonte: TONONI, 2008, p. 224.

Emaranhamentos têm grande impacto na compreensão de como as diferenças podem ser articuladas para gerar a informação necessária à formação de conceitos. E essa compreensão aponta na direção contrária do reducionismo clássico, no qual os conceitos são compostos por entidades separadas, definidas. O emaranhamento nos diz que a qualificação distintiva da experiência requer uma interdependência tal entre relacionamentos informacionais (possibilidades de escolha) de modo que estes não possam ser decompostos em elementos. O emaranhamento, em outras palavras, é a interdependência entre dois elementos de tal maneira que interagir com um significa fazer o mesmo com o outro. No nível da distinção (criação da informação) significaria criar algo novo, pois o produto do tensor (o emaranhamento enquanto uma área de interação mútua instantânea entre duas possibilidades de distribuição) não é uma justaposição das caracterizações de cada elemento, nem um amálgama destas ou 
qualquer outra combinação reducionista, mas uma interação conjunta das características que está acima e além dos elementos considerados isoladamente. Paradoxalmente, usando um exemplo da música, distinguir significaria "ouvir" dois sons como se fossem um só. Este é um modo de trabalhar com a informação que não é usual nas abordagens cognitivas, ou na organização do conhecimento, e, na verdade, sua lógica repousa mais na física quântica ${ }^{77}$ (onde dois elementos nunca são trabalhados independentemente) do que na lógica sentencial. Aplicando-se essa lógica a um exemplo do domínio da linguagem, tomemos o conceito "homem feminino",78. Embora estejamos usando ao mesmo tempo os conceitos homem/masculinidade e mulher/feminilidade, se isolarmos estes para explicar o conceito "homem feminino", acabamos destruindo esse conceito, assim como simplesmente somando estes não chegamos naquele, uma vez que é impossível medir o valor real atribuído a cada um (e assim chegar a uma soma "certa", isto é, a um cálculo proposional preciso do sentido envolvido). Também o contexto envolvido na urdidura conceitual é fortemente dependente do emaranhamento, uma vez que a torção que ele realiza para se projetar faz confluir um maior número de relacionamentos informacionais na especificação de um qualia. É só pensar no número de contextos subentendidos necessário para se processar a expressão "homem feminino", como "homem com aparência feminina", "homem com trejeitos femininos", etc., assim como a negativação destes, "homem sem aparência feminina, mas delicado" e outros, todos como convergências atuais ou potenciais que assim não estariam não fosse o emaranhamento. Por esta razão, as propriedades de contexto-dependência e de emaranhamento não são apenas atribuições do qualia-espaço, mas o modo como este é construído e, portanto, é o modo como a experiência é construída.

Para entender como essa experiência é construída, porém, é preciso entender a geometria da fenomenologia envolvida. Em outras palavras, como a hierarquia da

\footnotetext{
${ }^{77}$ Para Tononi a noção de informação integrada pode ser estendida para envolver a informação quântica, uma vez que os paralelos conceituais se coadunam: superposição quântica e superposição dos repertórios de escolha dos mecanismos; decoerência quântica e o repertório real do mecanismo; emaranhamento quântico e informação integrada (TONONI, 2008, p. 241, nota n. 14). Uma abordagem quântica também pode ser encontrada na teoria dos conceitos desenvolvida por Gabora e Rosch (GABORA; AERTS, 2009; GABORA; ROSH; AERTS, 2008), como será apresentado no próximo capítulo. Mas, se em Tononi essa aproximação é apenas um paralelo conceitual, e em Gabora e Rosch apenas o formalismo quântico é aplicado à teoria, nesta pesquisa também não será abordada a questão da natureza quântica da mente. Embora implícita na argumentação desses autores, nesta pesquisa só será abordada a lógica quântica enquanto alternativa para se pensar o modo de articular diferenças na teoria da informação.

${ }^{78} \mathrm{O}$ autor desta Tese desenvolveu os argumentos que seguem a partir desse exemplo dado pela Profa. Doutora Maria de Fátima Tálamo durante as aulas de Introdução à Linguística, no curso de graduação de Biblioteconomia e Documentação.
} 
experiência é idealizada. Na abordagem clássica, a experiência é construída a partir de percepções básicas, irredutíveis, como a "vermelhidão do vermelho", o cheiro de uma rosa, uma dor física em seu âmago, e assim por diante. Tal abordagem pressupõe a existência de experiências universais na base da mente, às quais são adicionadas experiências cada vez mais elevadas na hierarquia, ou seja, cada vez mais complexas e sutis e por isso mais individualizadas. Essa visão também deixa implícito que a cognição é construída passo a passo, desde as percepções mais brutas até aquelas mais refinadas e reflexivas, numa sequência linear e algorítmica. Tononi propõe algo diferente. $\mathrm{Na}$ base de um mecanismo qualquer (seja este um sistema psíquico ou outro) que gere informação integrada, na ausência de contextualização e emaranhamento suficientes para dobrar a forma em direções mais complexas, o relacionamento informacional será sempre ortogonal, gerando assim uma configuração rasa demais para subir à condição de experiência. Por outro lado, quanto mais emaranhado um conjunto de relacionamentos informacionais ( $q$-flechas), mais contextualizados (convergentes) estarão as bordas que conformam um qualia-espaço em evolução, deixando as áreas mais densamente emaranhadas (e por isso mais complexas) em volta das áreas menos densas (experiências mais elementares). Assim, um qualia no seu sentido filosófico (uma experiência elementar como a dor ou a "vermelhidão do vermelho"), estará, na verdade, no topo ${ }^{79}$ da hierarquia da experiência (ver figura abaixo).

79 Em filosofia, geralmente os qualia são considerados como estando na base da experiência. Eco, revisitando o tema, coloca a existência do qualia num Ground semiótico, como uma Experiência Primeira (Firstness), ou “quality of feeling” (ECO, 1998, 90-95). 


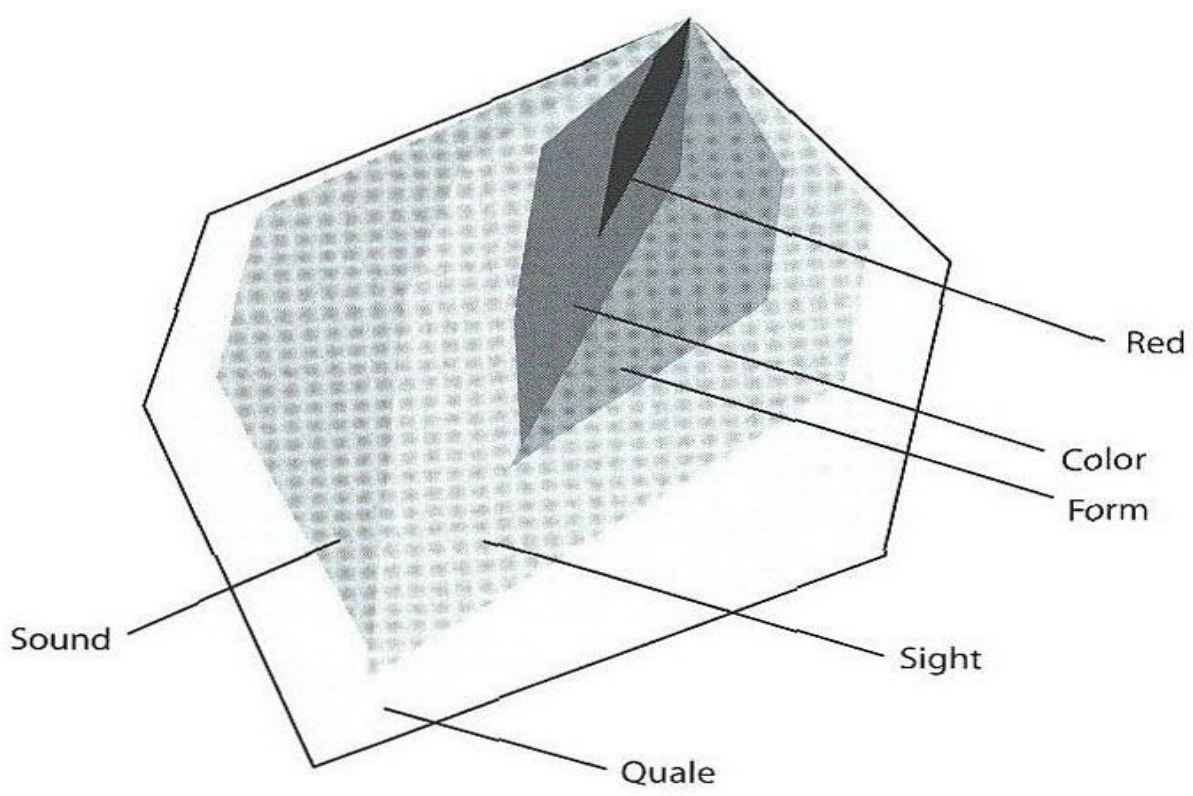

Figura 5 - Módulos em volta de uma experiência elementar

Fonte: TONONI, 2008, p. 231.

Na figura 5, o qualia do vermelho (a experiência elementar irredutível) não existiria não fossem as subáreas mais densamente emaranhadas (módulos). A visão subjacente dessa abordagem é de que, ao contrário de ser construída linearmente desde a base até as alturas mais sutis da individualidade, os elementos mais complexos e os mais elementares vão sendo construídos concomitantemente, com interações recíprocas. Essa abordagem acarreta consequências específicas na análise do acoplamento entre sistema psíquico e seu ambiente (o que inclui o social). Esse acoplamento não seria necessário se estivéssemos falando apenas hipoteticamente de um mecanismo de geração de informação integrada, pois, como afirma Tononi, tal mecanismo seria capaz de gerar consciência (e experiências conscientes) sem nenhum contato com o entorno, contanto que esse mecanismo incrementasse recursivamente sua capacidade de discriminar um grande número de estados internos. Para Tononi, “por mais estranho que isso possa parecer, um dia poderá ser possível construir uma entidade altamente consciente, e solopsística" ${ }^{80}$ (TONONI, 2008, p. 240, tradução nossa). Porém, tal mecanismo não pode surgir ao acaso e, como mecanismos fabricados pressupõem a

${ }^{80}$ Strange this may sound, the theory says that it may possible one day to construct a highly conscious, solipsistic entity. (TONONI, 2008, p. 240). 
existência de alguém já consciente, o único processo que sobra é o da seleção natural, o qual talha os organismos para serem adaptados ao ambiente. Portanto, mecanismos cerebrais, assim como a complexa informação integrada que geram, são o que são em razão de uma longa história evolucionária, desenvolvimento individual (ontogênese), assim como de aprendizado. A evolução biológica fornece o andaime (de desenvolvimentos genéticos e epigenéticos) para as conexões neurais, e a experiência refina essas conexões através da própria plasticidade dessas conexões, direcionando-as para a configuração de um conectoma ${ }^{81}$ individualizado e idiossincrático, a par das memórias que vão sendo incorporadas (TONONI, 2008, p. 240).

Mas Tononi pergunta: desde que a teoria (ITT - Teoria da Informação Integrada) afirma que experiências são relacionamentos informacionais dentro de um mecanismo, qual é a relação entre a estrutura desse mecanismo e a estrutura do mundo (TONONI, 2008, p. 240)? Para esse autor, a abordagem teórica mais simples é entender como os complexos de informação integrada "ressoam" sob certas escalas de tempo e espaço quando expostas (sob interação) ao meio ambiente. Através dessas escalas, um processo de seleção ocorreria (quase análogo ao da seleção natural), no qual qualias (construções da experiência) são selecionados sob pressão (das possibilidades de escolhas ofertadas na interação) e assim passam a compor os valores do organismo com relevância para a sobrevivência. Não é forçoso dizer que quanto mais plástico o processo oferecido para o conectoma, mais essa seleção estará voltada para os valores próprios do organismo do que diretamente ligados a questões de sobrevivência. Assim, o que a estrutura que subjaz ao processo de integração da informação faz é procurar projetar uma correspondência entre o relacionamento informacional interno (que não possui limites de conexão) e um relacionamento informacional externo (que é limitado pelas capacidades de interação, no espaço e no tempo). Do sucesso dessa correspondência projetada é de que dependem a continua seleção de um qualia, sua permanência (memória) e evolução (interconexão com outros qualias).

É neste ponto que ganha importância o modo como se concebe a construção da experiência, e sua hierarquia, sobre as possibilidades de escolha na interação. Se as experiências mais elementares, as que não podem ser reduzidas a outros elementos (e por isso são percebidas como as propriedades inerentes de qualquer categoria), estão no topo e não na base da construção da experiência, então não são imutáveis ou essenciais

${ }^{81}$ É o total de conexões entre neurônios de um cérebro, num dado momento. 
(como algumas classes aristotélicas, por exemplo), mas podem ser modeladas pelo conjunto dos conceitos adjacentes, estando na verdade ao alcance de qualquer nível de interação, mesmo aqueles não correlacionados diretamente com a experiência elementar. Por exemplo, a percepção da cor é fortemente condicionada, desde os bastonetes receptores de luz nos olhos (que só selecionam três frequências de luz), até sua produção numa área muito específica do cérebro localizada nos giros fusiformes da área V8 (TONONI, 2008, p. 231). É nesta área que se encontra o "correlato neural" de qualquer cor, e apressadamente poderíamos dizer que ali então é produzida uma relação estável de correspondência com o mundo, por exemplo, um correlato neural "vermelho" com $o$ evento "vermelho" no mundo, e teríamos aí uma propriedade categorial estável. Mas, como observa Tononi, é altamente improvável que um paciente em estado vegetativo que ainda possua atividade residual exclusivamente na área V8 possa vir a experimentar vividamente uma cor (Ibid., p. 231). Assim, a verdadeira experiência da cor só passa a ocorrer num estado de integração dinâmica da informação, de alta sensibilidade contextual. Como se pode observar na figura 5, a experiência do vermelho puro não está isolada, mas em correlação com sub-modos da experiência, como cor e forma, e estes englobados na experiência da visão, porém, mesmo esta também não está isolada, dentro dos limites do qualia há ainda o som. A “vermelhidão do vermelho" é assim uma experiência à qual se chega, como última seleção após trilhões de distinções sucessivas, e seu caráter de irredutibilidade é continuamente construído, ao contrário da visão tradicional, de estar dado por default. O seu caráter de representabilidade, de valor de correspondência ou ressonância com as estruturas do mundo, não está numa suposta representação basilar destas estruturas, mas no fato de estar no topo e no centro do qualia, portanto tributário de uma longa história de seleções (através dos domínios da evolução biológica e social) que talharam esse caráter através do qualia. Contudo, o qualia não deve ser entendido como uma forma restrita ou localizada em alguma parte do cérebro, sua representação geométrica na verdade é instanciada de forma distribuída, e ele pode se inflar e alongar em seus sub-modos em ressonância ao ambiente em resposta a mudanças nos estímulos (TONONI, 2008, p. 240). Deste modo, por exemplo, os sub-modos forma e cor podem se tornar mais densamente emaranhados e, portanto, mais sutilmente conceituais, mudando a contextualização da experiência elementar. A cor enquanto experiência elementar ainda estaria no topo e no centro do qualia, mas a experiência em si poderia ganhar um deslocamento para uma forma mais específica; um mesmo tom de vermelho sobre a palavra perigo seria considerado mais vermelho do que 
sobre a palavra paz. Esse fenômeno, de deslocamento da qualificação de experiências elementares (e podemos considerar generalizações muito extremas como os últimos elementos irredutíveis de uma forma ${ }^{82}$ ) sob formas específicas que a tipificam uma experiência como melhor que a outra como uma correspondência com as estruturas do mundo, foi constatado por Rosch (ROSH, 1975a, 1975b; MERVIS; CATLIN; ROSCH, 1975; ROSCH; SIMPSON; MILLER, 1976).

A questão central que se levantaria em relação a esta abordagem seria o quanto a inflação ${ }^{83}$ dos qualia poderia afetar a estabilidade de componentes cognitivos cruciais para a sobrevivência e por extensão para o manejo e reflexão adequados sobre as estruturas do mundo, como a cor das coisas, sua maleabilidade e posição no espaço. Principalmente quando esta inflação ocorre sob interações cujas escalas de tempo e espaço não possuem acoplamento óbvio com a percepção das estruturas do mundo. Nesses casos, o que salta à especulação é a questão da linguagem, pela sua abrangência como fenômeno regulador e ao mesmo tempo tão longe, aparentemente, do fenômeno da percepção das coisas pela totalidade dos sentidos. Uma pergunta antiga, por exemplo, é: o nome da cor e a percepção da cor podem ser a mesma coisa? A psicóloga cognitiva Lera Boroditsky lembra que "os linguistas americanos Edward Sapir e Benjamin Lee Whorf, que estudaram como as línguas variam, sugeriram que as pessoas aprendem a pensar de acordo com seu idioma nativo" (BORODITSKY, 2011, p.61). Nas palavras contundentes de Whorf:

Dissecamos a natureza em cortes prescritos por nossas línguas maternas. As categorias e tipos que isolamos do mundo dos fenômenos, não os encontramos por eles nos saltarem aos olhos; ao contrário, o mundo apresenta-se num fluxo caleidoscópico de impressões que deve ser organizado por nossas mentes - e isto quer dizer, em grande parte pelos sistemas lingüísticos que temos em nossas mentes. Seccionamos a natureza, organizamo-la em conceitos, e atribuímos significados da maneira como o fazemos em grande medida porque somos parte de um acordo para organizá-la assim - um acordo que vigora para toda a comunidade linguística e é codificada nos padrões de nossa língua. [...] Nenhum indivíduo é livre para descrever a natureza com absoluta imparcialidade, mas é coagido a certos modos de interpretação mesmo quando se julga mais livre. (WHORF apud OLIVEIRA, 1991, p. 7778).

\footnotetext{
${ }^{82}$ Um conceito geral para pássaro pode tropeçar na definição das palavras para circunscrevê-lo, mas um qualia cujos elementos-topo sejam apenas os traços mínimos de forma e movimento (das asas) e contexto (vôo) pode ser aplicado como um reconhecedor útil da "categoria" pássaro sob condições adversas de visualização.

83 Aumento explosivo da complexidade dos emaranhamentos informacionais (e, portanto, das possibilidades de bifurcações conceituais) ao longo da arquitetura do qualia.
} 
Porém, como observa Boroditsky, "na década de 70, a hipótese foi praticamente abandonada" (BORODITSKY, 2011, p. 61). Esse abandono pode ser creditado em parte às pesquisas de Rosh, Brown e Lenneberg ${ }^{84}$ (OLIVEIRA, 1991), que negariam o pressuposto do Princípio da Relatividade Linguística que a realidade como um todo era um recorte que cada língua fazia. O que estas pesquisas mostraram é que a existência de uma palavra para descrever uma cor numa dada língua não facilita mais a sua identificação por quem a fala do que por outro que não a domina, e pior: que línguas que não possuem palavras para certas cores não impediram que alguns indivíduos as identificassem (OLIVEIRA, 1991). As pesquisas apontariam para áreas de reconhecimento da cor mais definidas, em torno de 11 , reconhecíveis por pessoas de qualquer etnia. Esse fato sugeriria que a Língua não teria o poder de obliterar a percepção das cores básicas caso estas não constassem em seus vocabulários. Isso contradiz as teses do relativismo cultural radical, no qual prevalece a ideia de que o indivíduo está dentro de uma bolha cognitiva cujos limites são as categorias criadas pela cultura (mais ou menos como se fosse um solipsismo cultural). Por outro lado, seria precipitado afirmar que esse reconhecimento transcultural das cores focais significa que estas "constituem um universal cognitivo e refletem uma característica básica, estrutural, do aparelho visual humano" (OLIVEIRA, 2011, p. 82). Essa afirmação equivaleria a dizer que o aparelho humano sozinho se encarregaria de copiar do ambiente esse "universal cognitivo", restando ao cérebro a tarefa passiva de acomodá-lo em algum lugar. Confrontada com o que já discutimos sobre a natureza informacional do cérebro em Tononi, podemos dizer que essa afirmação não é suportada pela visão desse autor sobre como o sistema cognitivo trabalha. Pelo contrário, a existência de experiências perceptivas intersubjetivas não implica que estas derivem de estruturas compartilhadas (em qualquer grau de semelhança) entre os indivíduos, já que o conectoma (assim como toda a rede do sistema nervoso) difere tanto de indivíduo a indivíduo quanto as digitais. Como argumentam Maturana e Varela, o comportamento coordenado entre indivíduos gera um acoplamento estrutural através de uma correspondência entre configurações neuronais, o que não significa que estas últimas alcançam um homomorfismo, como se passassem a representar a mesma coisa.

\footnotetext{
${ }^{84}$ BROWN, R. Reference: in memorial tribute to Eric Lenneberg. Cognition, Lausanne, v. 4, p. 125-153, 1976.
} 
A riqueza plástica do sistema nervoso não se deve a que ele guarda representações ou "engramas" das coisas do mundo, mas à sua contínua transformação, que permanece congruente com as transformações do meio, como resultado de cada interação que o afeta. Do ponto de vista do observador, isso é percebido como uma aprendizagem adequada. Acontece, porém, que os neurônios, o organismo de que eles fazem parte e o meio em que este interage, funcionam reciprocamente como seletores de suas mudanças estruturais correspondentes e se acoplam estruturalmente entre si. O funcionamento do organismo, incluindo o sistema nervoso, seleciona as mudanças estruturais que permitem que ele continue a funcionar. Do contrário se desintegrará. (MATURANA ROMESÍN ; VARELA GARCÍA, 2002, p. 190).

O que liga estas experiências entre si, e a constância delas na percepção, é a correspondência entre as formas assumidas pelo qualia de cada um, mas esta correspondência é fruto de uma observação que se projeta na experiência, como "todas as maçãs são vermelhas", e não a uma cópia da maçã que se repete no cérebro de cada indivíduo. O qualia é uma virtualização de relacionamentos informacionais integrados, que só toma forma de fato (se transforma em percepção de algo) quando projetado na experiência, através da interação, e assim adquirindo sentido na observação (quando selecionado como um vínculo com a experiência). O que é compartilhado é o modo como o vínculo é construído, é a história de interações através de domínios distintos (evolutivo-biológicos, psíquicos e sociais) que estruturam as possibilidades de interação sob certas escalas de tempo e espaço. Se o vínculo é intermediado por estruturas fisiológicas e neuronais mais simples ao longo de uma escala de tempo mais longa, por exemplo, a experiência (de medo) dos vertebrados com o fogo ao longo de sua evolução, uma estrutura de natureza filogenética se imporá restringindo a articulação de estruturas interacionais ontogênicas (mais plásticas e flexíveis existentes no decorrer do tempo de existência dos indivíduos).

Dissemos e repetimos - para que não fosse esquecido - que todo comportamento é um fenômeno relacional que nós, como observadores, percebemos entre organismo e meio. Contudo, o âmbito de condutas possíveis de um organismo é determinado por sua estrutura, já que é ela que especifica seus domínios de interação. Por isso, cada vez que, nos organismos de uma mesma espécie, se desenvolvem certas estruturas independentes das peculiaridades de suas histórias de interação, diz-se que tais estruturas estão geneticamente determinadas, e que os comportamentos que elas possibilitam (caso ocorram) são instintivos. Quando, pouco depois de nascer, o bebê pressiona o peito de sua mãe e suga o mamilo, ele o faz independentemente de ter nascido de parto natural ou cesariana, ou de se veio ao mundo num luxuoso hospital de Santiago ou no interior. 
Ao contrário, se as estruturas que tornam possíveis determinadas condutas nos membros de uma espécie se desenvolvem somente se há uma história particular de interações, diz-se que as estruturas são ontogenéticas e que as condutas são aprendidas. (MATURANA ROMESÍN; VARELA GARCÍA, 2002, p. 191).

Grosso modo, portanto, estruturas há mais tempo existentes para lidar com o medo do fogo arrastariam essa experiência para cima e para o centro de um qualia, como algo que precisa ser básico, elementar e seguro. Porém, se a construção do vínculo com a experiência não é granjeada pelos dados sensíveis (o gosto desagradável de algo em decomposição não está na coisa em si, cuja composição química é a mesma para o lagarto que a degusta quanto para o mamífero que a rejeita), mas pela história das estruturas que tornam possível um tipo de interação ou outra, não será possível dizer no funcionamento presente do sistema nervoso que se observa o que é filogenético e o que é aprendido a menos que se tenha acesso à história estrutural pertinente (MATURANA ROMESÍN; VARELA GARCÍA, 2002). A dificuldade dessa intransparência aumenta na mesma ordem em que um sistema nervoso evolui em complexidade, a ponto de, nos seres humanos, "até mesmo a capacidade de aprender a andar ser fortemente dependente de ambiente cultural humano" (Ibid., p. 192). O ser humano também parece constantemente desafiar seu instinto para adaptá-lo a suas criações culturais: o medo do fogo se torna uma atração no circo, alimentos amargos ou perigosos se tornam iguarias em certas culturas. Estas evidências nos sugerem que a plasticidade do sistema nervoso é capaz de moldar até os aspectos mais instintivos do ser humano, o que nos faz, inclusive, colocar em suspeição o uso da palavra instinto em relação ao ser humano.

O pressuposto do Princípio da Relatividade Linguística de que o mundo perceptivo dos indivíduos seria tributário das nomenclaturas linguísticas parecia encontrar um contexto de aprovação no nível mais superficial dessas evidências. Como foi abordado, porém, essa presunção não leva em conta os aspectos evolutivos de longo prazo da cognição e a necessidade de tornar as experiências mais elementares e gerais valiosas como adaptações da espécie e, portanto, mais centrais e no topo como no modelo informacional de Tononi (como no caso das cores focais). A questão levantada anteriormente sobre o quanto a inflação de um qualia modificaria a consistência de experiências elementares deveria ser reformulada para o que é acrescido ao qualiaespaço de uma experiência elementar, uma vez que esta nunca some (está sempre no topo, em vez de na base, onde poderia ser soterrada) mas, por outro lado, está sempre no 
centro de um processo centrípeto que vai adicionando camadas de possibilidades contextuais $^{85}$. Sobre a natureza das influências da língua e da cultura sobre a percepção, o ponto de mudança na abordagem seria em como essas interações modificam a qualidade da construção da percepção, tendo em vista que estas interações direcionam sentidos possíveis (escolhas de posicionamento espaço-temporal e relacional distintos) e assim redimensionando qualidades cognitivas. Segundo Boroditsky, o levantamento de pesquisas recentes em estudos da linguagem e da cognição demonstra evidências suficientes para derrubar o dogma da universalidade e suportar em essência as teses de Sapir e Whorf, a de que línguas diferentes moldam diferentes habilidades cognitivas. Para essa autora, pesquisas em vários laboratórios "vêm mostrando como a linguagem molda dimensões mais fundamentais da experiência humana: espaço, tempo, causalidade e relacionamento com os outros" (BORODITSKY, 2011, p. 62).

Nessas pesquisas, o modo como a orientação no espaço é tratada por uma língua configura o modo de se posicionar e usar o corpo e de segmentar o tempo, formando esquemas de qualificação do espaço interpessoal e social. Por exemplo, os falantes do kuuk thaayorre (idioma falado em Pormpuraaw, uma comunidade aborígene australiana) não possuem palavras para posições relativas como esquerda e direita, em frente ou atrás, o que não quer dizer que eles não se situem nessas direções, mas o fazem em relação a escalas cardeais de posição: norte, sul, oeste, leste. O que em outras línguas é usado apenas eventualmente, em kuuk thaayorre é uma atividade cognitiva corriqueira, o que significa "que acaba se dizendo coisas como 'o copo está a sudoeste do prato' ou 'o menino em pé ao sul de Maria é meu irmão'” (BORODITSKY, 2011, p. 62). O impacto disso é que o indivíduo deve estar permanentemente orientado em relação aos pontos cardeais para falar corretamente, fazendo dessa orientação algo natural e incorporado ao ponto de poderem se orientar dentro de salas fechadas, algo inimaginável para indivíduos de outras culturas. Esse modo de sentir o espaço influi também na organização do tempo: enquanto falantes do inglês organizam uma sequência temporal da esquerda para a direita, e falantes de hebraico da direita para a esquerda, os falantes de kuuk thaayorre se posicionam para que a sequência comece no leste e termine a oeste (BORODITSKY, 2011). O sentido de tempo também parece ser construído em conjugação com a posição no espaço em outras línguas: falantes do

\footnotetext{
${ }^{85}$ Esta abordagem também poderia ser útil para dissipar debates infindáveis sobre o inato e o aprendido, uma vez que os dois fatores estariam sempre presentes, apenas alternando suas posições de atualização (e, por isso, dando a ilusão de virem antes ou depois).
} 
inglês, que consideram que o futuro fica "adiante" e o passado "atrás", balançam o corpo para frente ao pensar no futuro e para trás ao pensar no passado, enquanto falantes do aimará (um idioma andino), que tem invertida essa "posição do tempo" em sua língua, se inclinam para frente ao pensar no passado e para trás ao pensar no futuro (BORODITSKY, 2011). O mais importante dessas pesquisas, porém, está na constatação de que o aprendizado de mais de duas línguas cria modos distintos de vinculação com uma experiência, podendo ser esta qualificada de modos opostos. Boroditsky cita os estudos de Shai Danziger e seus colegas na Universidade BemGurion, em Israel, com falantes bilíngues em árabe e hebraico, nos quais se testava as tendências implícitas de associação com características positivas ou negativas frente aos nomes hebreus apresentados, sendo que essa caracterização (o dispositivo de escolha) era apresentada ora em hebraico, ora em árabe, obrigando os indivíduos bilíngues a julgar nomes hebraicos usando o hebraico ou o árabe. Com os indivíduos que eram de origem árabe esperavam-se respostas negativas consistentes para os nomes na língua da etnia em desafeto (a judia), mas o que se revelou foi que "os que falavam fluentemente árabe e hebraico mostraram atitudes implícitas mais positivas em relação aos judeus quando testados em hebraico que quando testados em árabe" (BORODITSKY, 2011, p. 63). Isto indica que possuir uma língua também acarreta ser "possuído" pelos laços sociais que construíram aquela língua, seu modo de qualificar as coisas e as relações humanas, mas por outro lado que não se pertence de modo fechado a este ou aquele mundo de referências culturais, e que é possível à mente manter registros contraditórios de lidar com o mundo. Contudo, passamos instantaneamente de um registro a outro através da linguagem, o que sugere que dependemos da linguagem para atualizar o uso de um registro e, portanto, direcionar-lhe um sentido.

A linguagem parece estar envolvida em mais aspectos de nossa vida mental que os cientistas previamente supunham. As pessoas confiam na língua, mesmo quando fazem coisas simples como distinguir manchas de cor, contar pontos em uma tela ou se orientar em uma pequena sala: meus colegas e eu descobrimos que limitar a capacidade de acesso às faculdades linguísticas fluentes de um indivíduo (dando-lha uma tarefa que exige competição, como repetir uma notícia) prejudica sua capacidade de executá-la. Ou seja: categorias e distinções próprias de determinados idiomas interferem amplamente em nossa vida mental. $\mathrm{O}$ que os pesquisadores vêm chamando de "pensamento" esse tempo todo na verdade parece ser uma reunião de ambos: processos linguísticos e não-linguísticos. Assim, pode não existir grande quantidade de pensamento humano 
adulto quando a linguagem não desempenha um papel significativo. (BORODITSKY, 2011, p. 63).

A partir destas considerações é que podemos entender os argumentos de Luhmann tanto para a separação entre sistemas psíquicos e sistemas sociais quanto para o conceito de consciência, no qual se separa a capacidade desta processar percepções e de "ter" pensamentos. Quando faz esta separação, Luhmann não pretende negar ou discutir "o fato de que a consciência possa pensar, ou tenha a capacidade de fantasias e imaginação, podendo simular, de alguma forma, a percepção" (LUHMANN, 2009, p. 276). Porém, Luhmann argumenta que também não há muito pensamento quando se retira os efeitos do acoplamento estrutural entre consciência e comunicação.

É extremamente difícil separar a operação pensante da consciência, sem que intervenha um escrito, um ruído, um som. $\mathbf{O}$ pensamento é um ganho muito específico, que, do ponto de vista teórico e histórico, nota-se claramente que não surgiu como qualidade específica do ser humano, mas como um ganho social. O pensar não surge pelo fato de que se vem ao mundo com os olhos abertos: é preciso aprender a fazê-lo. Em contrapartida, a capacidade de percepção se coloca mais além do último rincão da construção dos pensamentos. (LUHMANN, 2009, p. 276, grifo nosso).

Desta conceituação de consciência podemos começar a tecer uma compreensão dos sistemas de comunicação, pois dela podemos derivar que

[...] a estrutura da comunicação está completamente intermediada pela consciência, e não, por exemplo, pelos fenômenos auditivos ou óticos, como tais, pela linguagem. [...] Tudo que é possível comunicar, deve passar, primeiramente, pelo filtro da consciência, situado no meio do sistema de comunicação. Nesse sentido, a comunicação é totalmente dependente da consciência, e, ao mesmo tempo, algo que a exclui completamente, já que a consciência nunca é comunicação. (LUHMANN, 2009, p. 276, grifo nosso).

Através destas colocações, podemos entender, primeiramente, o uso da expressão "seleções de consciência", por Luhmann, como ocorrendo no nível do pensamento, isto é, no nível do compartilhamento das seleções de sentido, o qual é responsável pela existência e regulação de um sistema de comunicação através da reiterada seleção de seus elementos constituintes. A consciência está, assim, no centro da construção do sentido de uma escala de valores sociais, mas a consciência apenas compartilha o processo de seleção desse sentido (e todas as consequências decorrentes), mas não compartilha da "totalidade" desse sentido uma vez que as estruturas que 
perfazem a consciência não participam da totalidade do processo de organização do sistema social. Desta forma, a separação entre sistema psíquico e social ocorre nesse sentido de não compartilharem a mesma organização, e não por ilações sobre uma capacidade autoestruturante do sistema social. Destarte, se todos os indivíduos compartilhassem o mesmo sentido para uma dada experiência o sistema social cedo ou tarde alcançaria um estado uníssono, não oferecendo mais as dissonâncias necessárias para incentivar novas seleções de sentido e, portanto, levando este sistema à estagnação ou à autodestruição. A comunicação unívoca de um sentido na linguagem não deve ser confundida com o compartilhamento desse sentido. A linguagem fixa, via gestos ou sinais, um veículo para o compartilhamento de coordenações de escolhas de sentido, mas esse sentido não permanece homogêneo ou fixado nessa vinculação uma vez que, como diz Luhmann, a comunicação em si nada faz, nada distingue ou promove, ela apenas dispõe uma escala de coordenações coletivas de sentido na qual a consciência pode se mover em um sentido ou outro. A linguagem se torna, pois, o meio através do qual consciência e sistema social coevoluem por fornecer a recursividade necessária para ampliar tanto a capacidade de seleção quanto a oferta de sentidos possíveis, ao mesmo tempo em que leva os dois sistemas a um patamar em que um não existiria sem o outro.

O desenvolvimento da linguagem contribuiu para a diferenciação da consciência da forma em que ela nos é familiar, e que nos faz presumir que seja distinta dos animais, embora esses também possuam habilidades complexas de percepção.

Pela linguagem, a consciência se orienta ao entendimento permeado de sentido, e a comunicação garante uma circulação comunicacional permanente, não havendo, assim, o perigo de chegar à situação em que ninguém se entendesse e a comunicação se rompesse totalmente. (LUHMANN, 2009, p. 283).

Em segundo lugar, podemos recolocar o problema do fenômeno da informação em termos do acoplamento entre consciência e comunicação, assim como os regimes de informação emergentes desse acoplamento. O que deve ser esclarecido nessa recolocação é como esse compartilhamento de coordenações de sentido (o ponto crítico do acoplamento consciência/sistema social) granjeia modos de se trabalhar diferenças (criar informação) nos limites desses sistemas. Como estamos falando de sistemas de sentido, os quais orientam os indivíduos de uma experiência para a outra assim como os indivíduos entre si em relação a essas experiências, estaremos falando de modos integrativos e dissolutivos dessas experiências. Com isso queremos dizer que existirão 
modos de privilegiar a qualificação de uma experiência, expandindo-a, e outros de desprivilegiá-la, reduzindo-a - a consistência sistêmica na transformação de diferenças num modo ou outro seria o regime de informação nos limites de cada sistema. Uma vez que advogamos aqui a ideia de conceito como uma construção da realidade, identificar esses regimes pode ajudar a entender quando observamos um conceito enquanto uma integração de informações e quando não. Para tanto, trabalharemos a partir de um conjunto de premissas, alicerçadas em posicionamentos teóricos já colocados:

- $\quad$ PERCEPÇÕES SÃO INFORMACIONALMENTE NULAS - a construção perceptual está no âmago da atividade cognitiva, portanto, inacessível. Relembrando as teses de Tononi, a percepção é construída pela informação, que nesse nível do sistema é toda distinção que leva à discriminação de um número altamente crítico de alternativas, levando, por sua vez, a que esta distinção se configure como um conglomerado de relacionamentos informacionais (mais distinções, recursivamente) até que o conjunto possua um estado de emaranhamento suficientemente complexo para sustentar algo como uma experiência perceptiva. Desta forma, elementos perceptivos, como cores, formas, cheiros, sons, e mesmo as arquiteturas categoriais que possam vir a assumir (como a forma geral de pássaros, peixes, pedras, montanhas e outros), não são perceptos puros ou isolados, mas o resultado de uma teia de distinções que os rodeiam e influenciam. Isto é a inversão de uma crença arraigada que considera a informação composta de percepções, ou a informação um resultado da percepção. Capurro (2008) cita Agostinho e sua noção de "informatio sensus", a qual baseia a ideia de percepção nas metáforas de Aristóteles e Platão como um selo com a imagem do objeto que imprime na mente essa representação. Igualmente, muitas alusões à informação no senso comum fazem referência à percepção, como nas passivas expressões "o anúncio me informou", "fui informado pelo noticiário", e o próprio conceito que generaliza que "tudo é informação", ou seja, que todo objeto ou coisa "possui" informação. Nessa diluição, entendemos porque é difícil separar informação e percepção no dia-a-dia. É por essa razão também que fica difícil conceber uma percepção sem atribuir-lhe uma informação pertinente, que a comunique. Em outras palavras, como pode Marco Polo ver um rinoceronte e não conseguir descrevê-lo? O animal rinoceronte, porém, não surge das palavras, mas da capacidade de distinguir e derivar formas animais rapidamente porque isso significa ir atrás da caça ou correr de algo perigoso, uma articulação de qualias esculpida através de eras em que a espécie hominídea não possuía 
nem sequer órgãos da fala adequados. Assim como Marco Polo, herdamos de hominídeos mais primitivos as mesmas estruturas através das quais os qualias se organizam para também fazerem esse reconhecimento rapidamente. Porém, também herdamos outras estruturas ulteriores, como as que nos capacitam a articular sons e gestos mais sutis, que impõem aos qualias outras magnitudes de organização, inflando informacionalmente para lidar com a coordenação social daquilo que se esta vendo. Embora a experiência de ver o animal rinoceronte ainda esteja no topo do qualia, o entorno dos relacionamentos informacionais que a justificam pode estar tão inflado pela interação social que a não qualificação dessa experiência na coordenação comunicativa pode vir até a produzir uma desconfiança quanto ao que se vê. Daí, a angústia de Marco Polo.

- A INFORMAÇÃO COMO DISPUTA DE SENTIDO - ao se afirmar a informação como uma percepção, e ao não se ter acesso a como essa percepção foi construída, ao ser anunciada a informação se esvazia e se transforma em apenas uma constatação, nada mais se pode fazer com ela. Ao se anunciar que a informação é isto ou aquilo, portanto, estará se renunciando a pensar a informação. A questão pela informação não deve apenas inquirir pelo que ela é, mas pelo o que ela continua sendo o que é e, assim, poder continuar sendo usada para explicar o que se observa (e assim ser possível dizer que se observa um mesmo fenômeno). Quando se assume que informação é tudo aquilo foi usado em uma operação de informar ou ser informado, estará se renunciando à ambição epistemológica de explicar o fenômeno da informação, e o que permanece é o hábito de reificar a informação a cada contexto novo - vício epistemológico que acusamos no início deste capítulo. A ambição epistemológica pede, então, que explicitemos o que faz a informação ser o que é a cada instante que é usada.

A partir do que foi exposto previamente (no capítulo 2), de que a informação é, em princípio, uma diferença que resulta na reorganização (tópica, parcial ou integral) do sistema que a acolheu, o que temos que perguntar é como os sistemas psíquicos e sociais acolhem diferenças, a cada instante, e como as integram. A pergunta pode parecer muito complexa, mas se usarmos como baliza os sistemas abertos de informação (cuja organização é o reverso daquela encontrada nos sistemas fechados, como os biológicos) teremos um exemplo do modo como não podem trabalhar os sistemas psíquicos e sociais com as diferenças emergentes. Nos sistemas abertos, as diferenças são intercambiáveis, isto é, fonte e receptor podem ter estruturas muito 
diferentes, mas sempre será possível correlacionar diretamente as diferenças entre um e outro pela distinção como estão organizados. Isso significa que uma diferença entre $A$ e $B$ não é problema, trata-se apenas de replicar a diferença de $A$ em $B$, ou de $B$ em $A$, é uma questão tão somente de decidir se queremos que $A$ organize $B$, ou se $B$ deve organizar $A$. Como se pode notar, nos sistemas abertos a informação não possui um valor de fato, isto porque decidir entre $A$ ou $B$ possui o mesmo peso. Quando a diferença em $A$ for replicada em $B$ (ou vice-versa) será estabelecida uma paridade, uma igualdade, que, ao fim, significará a extinção da diferença num dos polos. Comunicar, nos sistemas abertos à informação, significa literalmente tornar algo comum entre fonte e receptor. Nos sistemas fechados à informação, ocorre o contrário, as diferenças não são intercambiáveis uma vez que mesmo sistemas compartilhando a mesma estrutura terão uma organização diferente, impedindo a correlação direta entre estas. Isso significa que uma diferença entre $A$ e $B$ é um problema, uma vez que não é possível estabelecer qual será a fonte e qual o receptor através da arbitragem da transferência da organização de um para outro. Esses sistemas, portanto, não poderão resolver os problemas de comunicação entre suas unidades compósitas através de paridades entre a organização destes.

Por outro lado, a impossibilidade de manipular diretamente $A$ e $B$ acarreta que estabelecer uma correlação entre ambos (seja $A \rightarrow B$ ou $B \rightarrow A$ ) implica numa atribuição de sentido, a par de uma margem de diferenças toleradas, ao invés de uma margem de paridades intercambiáveis. Trabalhar a partir de uma margem variável de diferenças significa que toda escolha será sempre diferente, portanto, não trivial. Se a isso somarmos que toda seleção de sentido precisa se correlacionar por coordenação (correlação indireta) com uma seleção concorrente de sentido (porque a margem de diferenças não conhece um núcleo de paridades) para validar essa mesma seleção, podemos antever uma disputa em torno dessa margem de diferenças, que configura tanto o risco de um sentido (seu peso ou "significado") quanto seu esvaziamento. Quando um indivíduo confere um peso a um sentido, ele se arrisca, porque essa “margem tolerável” entre as diferenças não terá como referência um valor indiferente entre ambas, ou seja, nunca se alcança uma zona de coincidência exata que "limpe" as diferenças.

A informação aqui, portanto, é de outro nível, ela estará sempre numa zona cinzenta de disputa de sentido. A percepção se distingue dela justamente por estar no 
centro dessa "margem de tolerância" entre as diferenças, em que a própria margem chega a desaparecer e qualquer diferença se dissolve na coordenação. Não se faz aqui uma afirmação contraditória, de que percepção é aquilo que não se percebe, ou de que percepção é aquilo que é processado inconscientemente. O que queremos propor é a existência de uma virada sistêmica da informação que permite a emergência de outra escala fenomênica. Para dar conta do fato de que a consciência produz distinções numa escala que não pode ser compartilhada, e que a coordenação entre indivíduos num meio social produz uma superabundância de possibilidades, produz-se um filtro através da emergência de uma escala mais acessível, na qual o sentido só é "percebido" enquanto em disputa e a comunicação só acontece enquanto houver diferenças pendentes na interação. A informação, nesse nível fenomênico, conjuga consciência e meio social selecionando, na consciência, "aquilo que chama a atenção" (numa disputa de sentido) em conjunto com aquelas coordenações sociais que reiteram ${ }^{86}$ aquilo que foi selecionado como item de atenção. Deste modo, a informação cumpre seu papel sistêmico de separação, mas também de ganho: ela separa ao sistematizar escolhas sociais que obedecerão a uma escala de tempo que a consciência não alcança (isto é, uma escala que vai além do indivíduo, transgeracional) e ao mesmo tempo causa um ganho ao disponibilizar - a qualquer tempo - o acesso a uma regularidade nas coordenações sociais (tanto como memória quanto como esquemas ao que deve ser esquecido). E esse ganho também se traduz numa economia psíquica, ao delegar às coordenações sociais o crivo da construção do sentido como a modelização do tempo, do espaço e das relações humanas. Porém, o que faz a informação ser o que é, a cada instante, é a incompletude da construção de todo sentido, é a latência permanente de diferenças na comunicação, sem a qual não existiria a tensão necessária que cria a necessidade da seleção de sentido. Em suma, uma seleção de sentido é uma inflexão que realiza uma mudança na construção do sentido (e por isso é informação: porque organiza o antes e o depois).

- $\quad$ BIFURCAÇÃO DO SENTIDO EM REGIMES DE INFORMAÇÃO - Embora a correlação indireta possa parecer um método impreciso (quando comparado com a equalização de diferenças na teoria clássica da informação), revela-se fundamental como um modo de criar informações, e não apenas repeti-las, através da conjugação não redutiva das diferenças, permitindo assim a emergência de regimes de regulação

\footnotetext{
${ }^{86}$ Ou que negam - a negação também é um processo de chamar a atenção.
} 
dessa conjugação. Assim como no efeito de emaranhamento de relacionamentos informacionais descrito por Tononi, um meio (que cremos ser possível) pelo qual são criadas possibilidades novas de sentido é pela superposição de mais de uma possibilidade de seleção de sentido, sem que nenhuma dessas possibilidades decaia para o nível da outra, ou ocorra uma seleção preferencial que reduza as outras ao estado de uma seleção singular. Como numa superposição ocorre um estado tensional, é previsível que a disputa de sentido continue no interior dessa integração informacional. Usando nosso exemplo anterior de "homem feminino", teríamos várias seleções de sentido ${ }^{87} \mathrm{em}$ superposição ( $\rightarrow$ "homem com aparência feminina" + "homem com trejeitos femininos" + "homem sem aparência feminina, mas delicado" $\rightarrow$ ), que, dependendo da ênfase da seleção (por exemplo: $\rightarrow$ "homem sem aparência feminina, mas delicado" + "homem com aparência feminina" + "homem com trejeitos femininos" $\rightarrow$ ), mudaria o eixo de orientação do sentido, impactando na integração de sentidos "homem feminino". O que faz, porém, com que a integração de sentidos "homem feminino", assim como as suas possibilidades de orientação, seja continuamente selecionada? Uma seleção de sentido é governada pelas possibilidades de interação, e estas sujeitas a escalas diferenciais no tempo e no espaço. Se há diferenças entre as escalas, então existem diferentes modos de organizar diferenças e, portanto, diferentes regimes de informação governando as possibilidades de interação. O sistema psíquico, por exemplo, trabalha em várias escalas de tempo ${ }^{88}$, mas podemos assumir que estas escalas estão na ordem de milissegundos, portanto, a consciência pode atualizar um emaranhamento informacional nessa escala. Por outro lado, as coordenações sociais são muito mais lentas, e sofrem a ação do espaço de separação entre os indivíduos. Enquanto no cérebro tudo está conectado, os indivíduos precisam assegurar que o espaço de conexão exista para que a coordenação ocorra. De certo modo, podemos dizer que o acoplamento entre consciência e sistema social ocorre primariamente em razão de um espaço de conexão coordenativo; quanto mais flexível e célere esse espaço mais a atualização cognitiva das possibilidades de sentido se aproximará da atualização coordenativa entre as diferenças de sentido entre os indivíduos. Assim, por exemplo, numa sociedade em que tempo e espaço são mais, respectivamente, acelerados e encurtados (como através dos meios eletrônicos), o acoplamento entre as atualizações de sentido será mais aproximado. A aproximação,

\footnotetext{
${ }^{87}$ Os exemplos entre parênteses devem ser vistos como uma abstração que não contempla o processo de emaranhamento em si. Qualquer uma dessas expressões implicam em alinhar definições, em fixar significados, o que destruiria o processo de manter integrados os sentidos concorrentes.

${ }^{88}$ Poder-se-ia dizer que o tempo é a verdadeira linguagem do cérebro.
} 
porém, também pode acelerar a taxa de atualização recíproca até o ponto em que o sentido se torna tão diluído que não mais oferece opções de seleção (ou seja, quando todas as opções se equivalem ou se tornam indiferentes). O acoplamento é, de fato, um ponto de equilíbrio entre a diluição e a impossibilidade de seleção de sentido. Esse ponto, contudo, é garantido pela tensão sempre existente entre os modos de seleção propiciados pelas diferentes escalas de interação ${ }^{89}$.

Esses modos de seleção são orientados pelo tempo dedicado a uma seleção, desde a atenção consciente dirigida, bem mais lenta que os ciclos de disparos neurais inconscientes, mas ainda assim muito mais célere do que a coordenação de uma conversa entre amigos, até uma coordenação transgeracionalmente cultivada (valores culturais). Esses modos se bifurcam a partir do ponto em que uma comunicação deixa de ser irreversível (deixa de ser construída no ato), ou seja, a partir de um ponto em que não é mais possível compartilhar a construção de um sentido ${ }^{90}$. Esse ponto de separação ocorre em torno de seleções que se independentizam do contexto inicial ou imediato, e que por este motivo requerem um investimento maior em termos de energia e tempo para serem atualizadas, ganhando assim uma natureza mais conservadora (conservação de um sentido presumido), ao mesmo tempo fragmentando e insulando as diferenças, reduzindo as margens de tolerância entre estas para uma dicotomia: dependência ou exclusão. $\mathrm{O}$ modo de seleção anterior a este ponto é o seu oposto: é uma expansão no trato das diferenças, no qual a tolerância combinatória se expande (a proximidade à construção do sentido permite a sua atualização), e a seleção, assentada numa codependência, torna-se produtiva. Quando estes modos se combinam sucessivamente na comunicação formam dois regimes de informação, respectivamente um regime redutivo e um regime expansivo-produtivo.

Para exemplificar como estes regimes se combinam dinamicamente na comunicação, vamos imaginar três cenários de interação com graus crescentes e distintos de reversibilidade da comunicação. Como cena comum de cada exemplo, a

\footnotetext{
${ }^{89} \mathrm{O}$ ponto desapareceria se a própria interação desaparecesse. Isso poderia ocorrer, numa ponta, pela extinção não só de todo contato externo como também interno, com a própria memória (algo improvável), e na outra ponta, pelo contrário, por uma conexão cérebro a cérebro, uma possibilidade que está se tornando assustadoramente real (ver NICOLELIS, M. Muito além do nosso eu: a nova neurociência que une cérebro e máquinas e como ela pode mudar nossas vidas. São Paulo: Companhia da Letras, 2011).

${ }^{90} \mathrm{O}$ sentido aqui possui o valor de tudo aquilo que é irreversível, e, por isso mesmo, não é possível de reparar para um estado anterior, dando um peso - e significado - maior na proporção da irreversibilidade assumida por uma tomada de sentido. Assim, a morte, pelo seu caráter de irreversibilidade absoluta, possui maior peso que a honra, mas se a honra é contextualizada como uma tomada de sentido que abrange todos os aspectos vitais de uma pessoa, a sua perda pode ser mais pesada que a própria morte.
} 
construção do sentido de ofensa assim como do seu contrário, a reparação. Imaginaremos a ofensa sendo cometida em três tempos de reversibilidade crescente: através de um tapa, através de uma carta e através de um e-mail. No primeiro cenário, o sentido é imediato, o modo de comunicar a ofensa é irreversível, o que foi comunicado (a interpretação não está em foco) não pode ser revertido, o tapa foi dado; contudo, a proximidade na interação permite uma atualização no sentido que não seria possível de outro modo, numa combinação de palavras, gestos e posturas que pode aproximar o esforço de reparação do contexto inicial. No segundo cenário é criada uma distância, existe um investimento de tempo e esforços, e se é possível reverter o que se escreve ou mesmo o envio da própria carta, a própria existência dessa reversibilidade confere um peso maior à ofensa escrita, pela reiteração da seleção do sentido de ofensa, que se soma ao investimento em tempo e energia nessa seleção. A dilatação ou o encurtamento nesse investimento tem seu efeito sobre a construção do sentido. Imagine-se uma ofensa enviada por correio no século XVIII, quando se sabe que uma carta leva meses para chegar a seu destino e que sua postagem não é barata nem fácil, com a postagem rápida, fácil e barata em pleno século XX - o peso da ofensa será maior no primeiro caso, no entanto, o investimento se duplica na reparação, dando-lhe mais peso, mas também um tempo de maturação mais longo e mais longe do contexto inicial.

Ao maior peso dado a um sentido, portanto, sobrepõe-se à necessidade de conservação de um contexto, precipitando-se à insulação do mesmo como unidade de sentidos atribuídos (significados), para compensar os investimentos em tempo e energia dispendidos. No segundo caso, ao menor peso dado à ofensa e à reparação, segue-se uma distensão à conservação do contexto inicial, permitindo uma maior recombinação de sentidos atribuídos, instando à fragmentação da insulação em unidades significativas. Essa recombinação chega a um paradoxo no terceiro cenário, o do e-mail (e que se acentua se imaginarmos meios mais instantâneos, como as redes sociais): o dispêndio quase zero de tempo e energia produzem um peso quase zero também na comunicação da ofensa, o que na verdade quase dispensa a necessidade de reparação, tornando o sentido da ofensa descontextualizado, portanto, incapaz de maturar uma insulação que fixe qualquer significado.

Se a comunicação humana fosse toda restringida a apenas ser realizada através da interação eletrônica, provavelmente após algum tempo sofreríamos com a ausência de significados novos para as coisas. Mas não é possível restringir a interação humana a 
apenas uma modalidade. Na verdade, a interação humana é por natureza multimodal, com a concomitância desses três cenários, ou os inúmeros desdobramentos possíveis a partir deles. Vemos frequentemente nas redes sociais reverberarem ódios sectários ou raciais, cuja seleção levou séculos para maturar, através de conflitos pessoais, paroquiais ou transnacionais, instilados por meio de conversações, sermões, discursos e fixados em palavras, escrituras sagradas e nas mídias massificadas. Contudo, a modelização da informação segue uma gênese condicionada: a falta de peso contextual na interação eletrônica gera recortes superficiais e redutores, que se acomodam bem a uma reprodução rápida, realimentando a seleção de elementos estereotipados. A "autopoiese" de um sistema social não é comandada pela reprodução de seus conteúdos culturais, como num círculo fechado no qual, por exemplo, "sistemas muçulmanos" só reproduziriam valores muçulmanos, mas em como essa modelização condicionada é regulada através da aderência a regimes de informação mais redutivos ou mais expansivos, e de como combinam esses regimes. Por exemplo, sistemas sociais com predominância de contextos comunicacionais interpessoais serão afeitos a regimes informacionais expansivos, isto é, capazes de contemplar diferenças contraditórias numa mesma distinção, como ocorre com certos povos animistas que não discriminam a orientação sexual de seus xamãs como uma mistura de dois comportamentos sexuais, um masculino e outro feminino, mas como uma transcendência. Por outro lado, a predominância desse regime informacional só favorece distinções globais, pulsantes, nas quais os objetos distinguidos não se afastam do contexto imediato. Gleick notou que Walter J. Ong, buscando provas de que a lógica formal foi possibilitada pela escrita, procurou nas pesquisas do psicólogo russo Alexander Luria sobre os povos iletrados do Uzbequistão e do Quirguistão exemplos dessa dependência entre lógica e escrita.

Luria descobriu notáveis diferenças entre os sujeitos iletrados e os letrados, mesmo que limitadamente letrados, mas não naquilo que sabiam, e sim em sua maneira de pensar. Lógica implica simbolismo: coisas fazem parte de classes, possuem qualidades que são abstraídas e generalizadas. Os povos orais não contavam sequer com as categorias que se tornam naturais até para indivíduos iletrados que vivem em culturas letradas: as formas geométricas, por exemplo. Quando mostraram a eles desenhos de círculos e quadrados, eles os identificavam como "prato, coador, balde, relógio ou lua" e "espelho, porta, casa, tábua de secagem de damascos". Não eram capazes de aceitar silogismos lógicos, ou se recusavam a fazê-lo. Uma pergunta típica:

No Extremo Norte, onde há neve, todos os ursos são brancos. Nova Zembla fica no Extremo Norte e sempre há neve por lá. 
De que cor são os ursos?

Resposta típica: "Não sei. Já vi um urso preto. Nunca vi de outro tipo. [...] Cada localidade tem seus próprios animais. (GLEICK, 2013, p. 47-48, grifo nosso).

Observe-se que na resposta do indivíduo iletrado há lógica, isto é, há uma coerência interna, não existe ausência de pensamento lógico, apenas não se aceita, ou não se ouve a pergunta como se ela fosse independente de seu contexto imediato. É preciso lembrar que na cultura desses camponeses abundam elementos imaginários: deuses, seres fabulosos e lendas. Não é por falta de imaginação que esse camponês não consegue imaginar ursos brancos. O que ele não consegue é usar a linguagem de um modo não integrado à sua experiência. Esse camponês talvez entendesse uma pergunta sobre as lendas de Nova Zembla, mas não se pode lhe pedir que considere "ursos" e "branco" como unidades independentes e que depois crie uma dependência entre elas de forma a criar algo que nunca experimentou. Para tanto, seria necessário que ele "visse" as palavras, que elas se tornassem independentes do fluxo sonoro, e esse próprio fluxo fosse recortado aqui e ali, reassociado a esses objetos, para se tornarem unidades livremente combináveis. Mas aí está o cerne da questão. O sentido é construído como uma expansão, através do emaranhamento de sentidos diversificados e conflitantes, mas amarrados à experiência de modo irreversível - de certa forma, o sentido só faz sentido como uma experiência irreversível.

Se pudéssemos repetir a experiência de ouvir Mozart ( $a$ experiência, não a música...), não existiria sentido nenhum nessa audição, provavelmente nem Mozart veria sentido em escrever músicas. Portanto, quando a linguagem faz referência a um sentido desacoplado da experiência, mas a partir de algum contexto sucedâneo, ela apenas faz um desafio à compreensão dessa experiência, mas quando ela faz referência a seu próprio uso se desacopla do fluxo da experiência, desafiando a própria construção do sentido. Uma compensação precisa, então, ser feita para continuar garantindo o sucesso da comunicação e a coesão social: um regime de verificação, de autoconsciência da linguagem, que tratasse toda diferença como dependente da seguinte e da anterior, como num algoritmo, ou como exclusão ou negação dessa diferença, assim colocando a liberdade combinatória sob um regime de verificação. A manobra, contudo, leva a pressupor essas cadeias de dependências como fruto de um processo independente (de implicações já postas, seja no mundo ou na mente), da realidade e das palavras, inclusive da autoconsciência que temos delas, gerando uma projeção 
“objetivada”. Como observa Gleick, "os povos letrados consideram sua própria consciência das palavras um dado, junto com o conjunto de máquinas relacionadas à palavra: classificação, referência, definição” (GLEICK, 2013, p. 48).

O camponês ${ }^{91}$ e o letrado, de fato, lidam com a realidade a partir de domínios disjuntos: o primeiro a vê como algo que é preciso ir criando na experiência, mas sem consciência desse processo, não a interroga; o segundo a vê como algo já existente, independente, mas que para passar a existir na experiência é preciso primeiro que se justifique. A seguinte passagem do livro de Gleick ilustra esse antagonismo entre os dois regimes de se informar: " 'Tente me explicar o que é uma árvore', diz Luria, e um camponês responde: 'Por que eu deveria fazê-lo? Todo mundo sabe o que é uma árvore, e ninguém precisa que eu explique isso.' " (GLEICK, 2013, p. 48). Contudo, não seria lícito imaginar que um regime suplanta o outro, a partir da invenção da escrita. Assim como o camponês do exemplo de Gleick convive com relógios e outros objetos manufaturados pelas culturas letradas, toda cultura letrada convive com os sentidos dúbios na linguagem, as metáforas e o pensamento mágico. Como defende Gabora (2009), esse seria um jogo que existe desde a origem do Homo sapiens, no qual os frutos do pensamento associativo (como interações entre conceitos díspares mantidos num estado emaranhado) se tornam os ingredientes para um pensamento analítico, e vice-versa. Apenas o incipiente pensamento analítico do homem primitivo se transformou num regime de informar-se mais complexo, por meio da expansão do modo e dos meios de comunicação, possibilitou aos regimes expansivos e produtores de sentido não só um meio de conservação do conhecimento vivido, mas também de um tempo antes inexistente para a reflexão e maturação desse sentido em alternativas antes insuspeitas, as quais, no entanto, precisam voltar para o seio dos regimes expansivos para serem validadas e ganharem peso (significado).

Esse ciclo, ou acoplamentos progressivos, entre os regimes sistêmicos de informação, tem a ver com o modo como consideramos a realidade, e como deste modo derivamos conceitos. Para compreendermos como estes conceitos se formam precisamos, portanto, ultrapassar o modo do camponês iletrado, que, imerso na experiência, não interroga a realidade da mesma (não se coloca como observador), e ultrapassar o modo do letrado que interroga a realidade, mas a considera como já dada 91 Considere-se, como já afirmado, o camponês não só iletrado, mas totalmente isolado de culturas
letradas - algo difícil hoje em dia com a globalização. 
(separa o observador da realidade). Para tanto, nos voltaremos para a abordagem de Maturana (2002), que separa o modo de lidarmos com a realidade em dois domínios: o da realidade sem as aspas (Realidade), que incluem os dois modos citados acima (contemplativa de uma realidade independente), e o da realidade entre aspas ("realidade"), na qual é o observador que cria a realidade e se interroga sobre a mesma.

Os conceitos, enquanto problema epistemológico para a Ciência da Informação, serão analisados a partir do domínio predominante da realidade sem aspas, e o decorrente antagonismo entre regimes integrativos e segregativos. Enquanto problema informacional, a formação dos conceitos será analisada a partir da abordagem da realidade entre aspas, como proposta de conciliação desse antagonismo, que considera os conceitos como microssistemas que altercam regimes expansivos/integrativos e abstrativos/segregativos de informação. 


\section{Capítulo 4}

\section{A Formação Sistêmica dos Conceitos}

Antes de começarmos a analisar como a Ciência da Informação enxerga a formação dos conceitos, resumiremos os principais pontos até aqui traçados que servirão como contexto teórico para essa análise.

O ponto central diz respeito à natureza da comunicação e à articulação da informação através desta. Tradicionalmente, a comunicação seria orientada através do "que há em comum" e à informação caberia o papel de veicular o que há de novo, mas com o fim de restabelecer um partilhar comum. O paradigma padrão é da existência de um desequilíbrio (entre dois indivíduos, entre sistemas, ou entre indivíduo e sistema) no conhecimento compartilhado, que leva à dúvida ou incerteza, o que seria superado pela operação de vincular o novo ao conhecido, informando (restabelecendo o equilíbrio) na parte receptora do processo. Deste modo, mesmo sendo a informação conotada como notícia ou conteúdo novo, é a sua capacidade de reequilibrar, de vincular ocorrências homólogas, a responsável - no paradigma padrão - por fazer a comunicação funcionar; ou seja, a informação guarda com a comunicação a mesma natureza de se orientar pelo “compartilhado em comum”. É um esquema que funciona bem enquanto podemos fazer coincidir a operação da informação com a ocorrência da informação. Tornar operacional a ocorrência da sequência "100001" com a ocorrência da expressão "Hello world" é fácil, porém, fazer coincidir a ocorrência de compreender a relatividade com a ocorrência de mostrar a fórmula $E=m c^{2}$ já se figura mais difícil, uma vez que a operação envolvida entre informar e compreender está longe de ser manejada com a mesma facilidade. No segundo caso, já seria difícil entender que a ocorrência $E=m c^{2}$ informa duas pessoas de que estão vendo a mesma coisa, a fórmula de Einstein, ou seja, que estão se referindo à mesma percepção. Verificar se dois computadores partilham a mesma informação é, pois, fácil, mas verificar isso em duas pessoas é impossível porque existe apenas a ocorrência do informar e do informar-se, não existe uma operação de compartilhamento, que torna-se, assim, presumido. Umberto Eco (1998, p. 
117), por exemplo, argumenta que todos conservam um Tipo Cognitivo ${ }^{92}$ (TC) comum, que se baseia na operacionalização do reconhecimento e da referência feliz (referência coroada de sucesso comunicacional). Eco está longe de propor a existência de conteúdos ou imagens mentais armazenados em comum (como no cognitivismo representacionista), porém se mantém na interpretação de que a comunicação é orientada para perseguir zonas de competência comum. $\mathrm{O}$ autor fornece o exemplo de um zoólogo e de uma pessoa comum (o próprio autor) que reconhecem no canto de uma sala um rato, cada um a partir de competências descritivas distintas, mas com uma zona de convergência: "no momento em que tanto eu quanto o zoólogo concordamos em reconhecer um rato, ambos citamos a ocorrência a nós fornecida pelo campo estimulante a um mesmo TC que o zoólogo sabe interpretar em termos de $\mathrm{CN}^{93}$ " (ECO, 1998, p. 153). Contudo, o próprio autor adverte que o compartilhamento do TC não pode ser fornecido.

Até agora disse que eu e o zoólogo "possuímos" uma zona de competência comum, e identifiquei esta zona com o TC e com CN que dela elaboramos. Poderia surgir a dúvida, visto que tanto eu quanto o zoólogo possuímos o mesmo TC, de que ele nos seja fornecido. Suspeita legítima, pois parece que nasce de experiências perceptivas, tanto minhas (que já vi e sei reconhecer ratos) quanto de quem as transmitiu (quando me ensinou a identificar ratos).

Mas se esta zona nos é fornecida, então é espontâneo perguntarmo-nos se se trata de uma entidade depositada em algum lugar, como as espécies, as essências ou as ideias de memória antiga. Se assim fosse seria igual para todos (e, no fundo, o próprio problema de Kant era como tornar igual para todos um procedimento esquemático que, ao menos na terceira Crítica, se transformava em trabalho conjectural); e, por sua vez, vimos como está ligada às disposições e às experiências do sujeito [...]. Esta competência comum é continuamente negociada ou contratada (o zoólogo concorda em ignorar algo que sabe do rato, para aceitar apenas aquilo que eu sei, ou contribui para enriquecer meu TC do rato, fazendo com que eu note algo que me havia escapado). E pode ser negociada porque o TC não é uma entidade (mesmo que pareça desenvolver a função que geralmente damos aos conceitos): é um procedimento - no sentido em que o esquema kantiano é um procedimento. (ECO, 1998, p. 154).

Uma consequência (não percebida por ECO) desse raciocínio seria esta: se a zona de competência comum é continuamente negociada ou contratada, então ela é um resultado desse processo, e não o próprio campo de forças que possibilita a

\footnotetext{
${ }_{92}$ É como Eco denomina uma concepção mais solta dos protótipos de Rosch.

${ }^{93}$ Conteúdo Nuclear: os principais traços descritivos de um Tipo Cognitivo (TC).
} 
comunicação ou a semiose. Esse campo, por outro lado, pode ser encontrado nessa disputa de sentido que a ideia de negociação suscita, como engajada através de uma zona de diferenças permitidas entre possibilidades de TCs; isto é, não se chega a um TC comum, mas a uma zona de coexistência entre as disposições e experiências que exprimem o reconhecimento de um $\mathrm{TC} / \mathrm{CN}$. Isto é muito diferente de dizer que a comunicação se orienta por zonas em comum. De fato, zonas em comum são como zonas mortas ou de acoplamento indiferente para a atenção; a nossa atenção é chamada pela diferença, mesmo quando estamos realizando equivalências. $O$ que informa é a diferença, as zonas em comum são como uma resultante, algo do qual já foram limpas as diferenças que a (in)formaram. E aí reside outra distinção ausente nas argumentações de Eco (assim como nas abordagens cognitivistas em geral): a ocorrência da informação não é fornecida pelo campo estimulante, é realizada pelas diferenças atribuídas a um estímulo ou outro, isto é, a informação é a diferença relacional entre a atribuição $x$ e a atribuição $y$ dado a certo campo estimulante. Ou seja, o estímulo traz suas próprias cargas e pressões, mas ele apenas "estimula", não informa, não é capaz de dizer ao sistema nervoso como ele deve se informar sob qualquer aspecto. Portanto, o continuum indiferenciado (se for ser identificado com campos estimulantes ou o ambiente), não pode conter linhas de força que privilegiam ou negam interpretações dos fenômenos, das coisas ou objetos. E se o continuum for trazido para o âmbito das realizações do sistema nervoso deixa de existir como etapa anterior à interpretação.

A noção de continuum seria talvez mais bem aplicada à noção de perturbação, desenvolvida por Maturana (2002), como um contato com estruturas determinadas do ambiente que desencadeiam respostas do sistema nervoso; uma série de perturbações encadeadas, com diferentes níveis de cargas e pressões, comporia um continuum. Mas este continuum não compõe uma "realidade", apenas regularidades às quais se agarram interpretações que igualmente se tornam regulares, ou seja, se acoplam ao continuum sem dele derivarem, e o exemplo mais premente disso é que de um mesmo continuиm podem surgir "realidades" divergentes ${ }^{94}$. De fato, as perturbações ambientais em si não são um "continuum", já que apresentam todo tipo de descontinuidades, sendo as regularidades produzidas pela leitura cognitiva melhor descrita como um "continuum cognitivo". Quando estas regularidades são divisadas como ocorrências dadas, a

\footnotetext{
${ }^{94}$ Como num exemplo fornecido anteriormente, no qual o encadeamento das moléculas num pedaço de carne apodrecida é interpretado como repulsivo por certos mamíferos (como nós), e como iguaria por certos répteis.
} 
informação se torna um mero encaixe na comunicação, reforçando a noção de que esta gira em torno de regularidades compartilhadas cujas lacunas seriam transpostas pela ocorrência da informação. A razão pela qual o conceito de informação de Shannon (maior quanto maior a indeterminação de uma mensagem) parece contra-intuitivo reside nessa identificação da informação com uma percepção que fornece uma transposição de percepções deficientes (lacunas), que redundam em conhecimento falho ou insuficiente.

Essa identificação produz dois problemas para a teoria do conhecimento, repercutindo na teoria do conceito: a informação fica destituída da compreensão de sua operacionalidade sistêmica no âmbito da comunicação humana, transformada em uma ocorrência que fornece a ligação entre "competências em comum", e como consequência secundária dessa orientação pela construção de competências em comum através da informação provém a ideia de que o objetivo do conhecer é alcançar uma definição (isto é, qualquer definição é alcançável através de informações fornecidas pelo campo estimulante). Em suma, é a própria noção fraca de informação (no sentido que esta não possui um papel pró-ativo), que propicia uma noção forte de representação, em que a definibilidade de qualquer fenômeno é colocada em termos de suas propriedades objetivas.

Não inventariamos nesta pesquisa todas as variações do conceito de representação, nem pretendemos analisar onde e como uma noção forte de representação surge na literatura sobre teoria do conceito em Ciência da Informação, muito menos afirmamos que não é possível existirem noções de representação que levam em conta a relativização da definibilidade dos conceitos. Colocamos apenas, como nossa hipótese de trabalho que, onde e quando uma noção fraca de informação for colocada, existirá uma tendência de colocação da noção forte de representação como complementação, seja implícita ou explicitamente. Por esta razão, é nosso objetivo, a partir daqui, colocar uma noção forte de informação como baliza para a análise dos problemas de conceituação da formação dos conceitos em Ciência da Informação.

Nos capítulos precedentes, discutimos as abordagens sistêmicas de informação. Neste, faremos uso do conceito sistêmico de informação, proposto aqui como a noção forte de informação. Qual o sentido dessa noção? O de que não existe fenômeno que não seja precedido ou tributário do processo da informação, seja qual for a forma que esse fenômeno tomar. Poder-se-ia argumentar a partir da dimensão física dos fenômenos, cuja constituição última é composta, para a Ciência, pelas diferenças entre 
os momentos quânticos de cada partícula dentro de um conjunto observável. Mas esse argumento é fruto da observação, e o que nos interessa é incluir a observação como fenômeno de estudo, isto é, como a observação se constitui para constituir os fenômenos que observa. É a partir desta abordagem que elegemos a distinção como unidade fenomênica de análise, como foi defendida por Maturana e Varela (2002), para os quais a observação surge das correlações entre as diferenças internas do sistema nervoso como uma distinção incorporada enquanto atitude em relação ao meio. A partir dessa compreensão aplicamos a conceituação de informação de Luhmann, em um nível mais abstrato, segundo a qual a informação é comitente ao ato de "drawn a distinction". Com esta frase de Brown, Luhmann queria dizer que a própria distinção (e, portanto, qualquer forma de conhecimento) só surge da tensão diferencial que o traço divisório impõe necessariamente entre dentro e fora, e que a cada vez que preciso redefinir esse traço mudo essa tensão diferencial, chegando, de acordo com o devir desse traçar, a uma forma. Deve-se notar que essas diferenciações que informam não pertencem à forma. Uma pedra sobre o chão não possui informações sobre sua forma, ela continua lá com sua estrutura e à mercê dos processos que a afetam (erosão, terremotos, etc.), mas a distinção sobre sua forma só surge porque a(s) diferença(s) entre dentro e fora dessa pedra (seus limites) estão relacionadas contextualmente com alguma posição observacional. Isto é, não haverá pedra a menos que eu seja um observador que nela possa tropeçar, ou pegá-la para me defender, ou chutá-la como uma bola. Para a bactéria incrustada no meio da pedra ela é apenas um meio circundante, ou qualquer outra coisa para a qual não temos categorias.

A informação não é uma coisa ou alguma propriedade intrínseca que se obtém, mas a realização de uma diferença, binária em sua expressão mais simples (dentro/fora, sim/não, embaixo/acima, etc.), mas esta simplicidade é enganosa, pois, como vimos, mesmo a mais simples das experiências necessita da concorrência de uma miríade de diferenciações na distinção. E, mais do que isso, "a informação que não está integrada não pode ser associada a uma experiência e, portanto, não existe como tal" (TONONI, 2008, p. 27). O conceito sistêmico de informação, portanto, se desdobra para acomodar essa complexidade: a coexistência de um modo de tratar a diferença simplificada, redutiva e abstrata, com um modo integrado, expansivo e associativo. É uma abordagem de informação que opta, ao mesmo tempo, pela explicação mais simples, a informação como o modo de se admitir uma diferença, mas também pela explanação mais complexa 
dos desdobramentos de contextualizar esse modo de acordo com o sistema que executa essa diferenciação. Em se tratando do fenômeno humano de conceitualizar, essa contextualização passa pelos sistemas psíquicos e sociais, suas dependências e retroalimentação mútua, assim como a coevolução pela qual passam. No entanto, antes da aplicação do conceito sistêmico de informação, é preciso colocar os problemas colocados pela literatura, em Ciência da Informação, concernentes à preocupação com a formação dos conceitos. Os problemas principais já foram apresentados em trabalho anterior (DERQUI, 2012), a partir dos textos levantados para o Corpus desta pesquisa.

Há ausência de indicações de qualquer tipo de preocupação teórica sobre o papel do fenômeno da informação na formação das categorias;

As noções mais comuns de informação encontradas, tacitamente aceitas, são as de informação no mundo (oriundas dos próprios objetos) e a de informação na mente (compondo as próprias categorias);

Existe uma dicotomia na abordagem do problema da formação das categorias, que se traduz no que foi denominado "o problema da conciliação" (OLIVEIRA, 1991), o qual se divide numa visão da formação dos conceitos a partir da Psicologia (construção prototípica das categorias no modelo de Rosch) e outra a partir de lógicas rigidamente hierárquicas (teoria clássica do conceito). Como indica o nome, o problema é visto como uma necessidade de conciliar duas abordagens opostas para o problema da formação das categorias, portanto, as propostas para superá-lo oscilam entre se compreender a questão a partir da complexidade do psicológico (OLIVEIRA, 1991) e entre tentar combinar as propostas (LIMA, 2010). (DERQUI, 2012, p. 421).

Podemos dizer, em linhas gerais, que os problemas levantados se limitam à última questão, "o problema da conciliação", uma vez que as referências à questão da informação não entram no bojo das preocupações com a formação dos conceitos. A partir dessa constatação traçaremos nossa análise. Não serão esmiuçadas, nesta pesquisa, as diversas linhas teóricas analisadas e cotejadas pelos autores do Corpus, mas os principais impasses que revelam, paradigmaticamente, como pode ser abordado esse problema de conciliar abordagens clássicas e modernas na questão da formação dos conceitos. Apenas com o fim de situar essas duas abordagens, serão descritas suas principais características. A abordagem clássica remonta aos antigos gregos, notadamente Aristóteles (criador de categorias fundamentais que, segundo ele, norteariam o entendimento do mundo), e perpassa toda a filosofia até Kant, mas em comum está o uso da lógica para explicar a formação dos conceitos, identificando o 
processo de pensar com o processo de realizar deduções lógicas, tendo como objetivo a eliminação da ambiguidade e da indeterminação.

A teoria clássica de Aristóteles é considerada por alguns como a hierarquia perfeita do mundo. Nela, as categorias são definidas apenas pelas propriedades comuns a todos os seus membros. Desta forma, nenhum membro pode ser considerado melhor exemplo da categoria que os demais. As categorias são definidas apenas pelas propriedades inerentes os seus membros. Assim, elas devem ser independentes de quem estiver categorizando, ou seja, ela não deve ser influenciada pelos movimentos do corpo humano, pela neurofisiologia humana, pelas capacidades humanas de percepção, pelo aprendizado, pela lembrança, pela comunicação ou por fatores sócio-culturais. A teoria clássica fornece uma explicação direta para o fato de separarmos membros e não membros de uma categoria. Os membros de uma categoria são justamente aqueles objetos, ou exemplares, que exibem as características necessárias e suficientes que definem a categoria; e os que não exibirem essas características são considerados não-membros, possibilitando, também, uma formação intuitiva do conceito. Formamos conceitos quando temos vários membros de um grupo, e determinamos as características únicas que dividem esses membros em classes separadas. Assim, nesse modelo, está claramente demarcado o que constitui ou não um exemplar de uma categoria, cujas fronteiras estão claramente definidas. Quando as categorias são organizadas em hierarquias, as categorias mais específicas incluem todos os atributos das categorias mais gerais. (LIMA, 2010, p. 112-113).

A abordagem moderna, por seu lado, embora também tenha raízes e até pontos em comum com a filosofia moderna, teve seu impulso nos laboratórios de psicologia, que começaram a investigar empiricamente como a mente forma e identifica conceitos. Buscando identificar como os indivíduos nomeiam aquilo que percebem, esta abordagem deixou de lado as grandes elucubrações lógicas e as grandes construções hierárquicas dos conhecimentos humanos, concentrando-se nos processos de categorização de objetos e conceitos comuns (lápis, cadeira, cães, pássaros, etc.). Por não se prenderem ao preceito logicista de formação das categorias, essas pesquisas puderam examinar empiricamente o processo de formação das categorias. O que essas experiências mostraram foi que o ser humano não segue exatamente um roteiro lógico na categorização, mas discriminam conceitos com base em características preferidas de exemplaridade, e não sobre características gerais aplicáveis a todos os membros de uma categoria. Essa descoberta, assim como outras, lançou um forte questionamento contra a ideia clássica de que todas as categorias se formam através da separação entre as "características necessárias e suficientes" (gerais) e outras "não essenciais ou 
acidentais" (particulares). Outras ideias alternativas surgiram desse questionamento, porém, sem se diversificar, propunham que o foco da cognição se concentraria na exemplaridade, isto é, na ideia que um membro da categoria reuniria as características representativas de toda essa categoria. Dentro dessa abordagem, o modelo cognitivo de maior repercussão foi o de protótipos.

Foi Eleanor Rosch quem transformou a categorização em uma questão de pesquisa. Desenvolvendo seus trabalhos na década de 70 , criou o modelo de protótipo baseado na tese de que, se no modelo clássico as categorias são definidas somente pelas propriedades que todos os membros da classe possuem, então nenhum membro pode exemplificar a categoria melhor que outro (ROSCH, 1975; 1978). O princípio fundamental deste modelo sustenta que as categorias são organizadas em torno de protótipos centrais. Um item é considerado como membro de uma categoria não por se saber que ele possui um determinado atributo ou não, mas por se considerar o quanto as dimensões desse membro se aproximam das dimensões ideais para ele. Em outras palavras, um exemplo representativo de uma classe seria aquele que compartilhasse com os outros membros da categoria do maior número de características e que, por outro lado, compartilhasse de poucas características (ou nenhuma) com elementos provenientes de fora da classe. De acordo com o modelo de protótipo, conceitos são representados por um grupo de características, e não por suas definições. Um novo membro é categorizado como um tipo de conceito se é suficientemente similar ao seu protótipo. O agrupamento de conceitos em uma dada categoria se daria, segundo a pesquisadora, não pela alternância dos traços binários, mas pela semelhança com o protótipo, em que o membro condensasse os traços mais característicos da categoria. Um pintarroxo é uma ave mais prototípica do que uma galinha ou um pinguim; o que o faz ser mais facilmente reconhecido como uma ave e menos provável que seja classificado erroneamente como membro de outra categoria [...].

Rosch e Mervis (1975) mostraram que quanto mais prototipicamente um membro de uma categoria é julgado, maior será a quantidade de características comuns que ele terá com os outros membros desta categoria, e menos atributos comuns com membros de categorias contrastantes. Em resumo, protótipos são justamente aqueles membros de uma categoria que mais refletem a redundância da estrutura de uma categoria como um todo. Assim, um canário é protótipo de um pássaro, mas uma galinha não é. (LIMA, 2010, p. 116-117).

Como observam Gabora, Rosch e Aerts (2008, p. 88, tradução nossa), “a teoria de categorização graduada de Rosch, de forma geral, era de que conceitos e categorias se formam para espelhar as estruturas do mundo real (tanto da percepção quanto das 
atividades da vida) mais do que a lógica em si" ${ }^{\prime 95}$. É desse contraste que nasce o primeiro impasse: a impossibilidade de se abrir mão do que a abordagem clássica já conseguiu, em termos de coesão lógica dos conceitos, em favor das abordagens modernas, que apontam para a extrema contextualidade do processo de categorização. A falta de flexibilidade da abordagem clássica para lidar com a contextualidade dos conceitos é motivo para abandoná-la? Para Oliveira (1991) não é, e entre as razões para isso cita o universalismo da intuição que diz que conceitos possuem propriedades definidas, independentes de contexto, que tornam compreensível o mundo, e, segundo esse autor, esse motivo é sustentado por pesquisas como as de McNamara e Sternberg ${ }^{96}$, citadas por Medin e Smith (1984).

A idéia de que os conceitos de objetos não têm propriedades que os definem vai contra as intuições de muitas pessoas (ver McNamara e Sternberg, 1983). Embora essas intuições frequentemente tendam a ceder a exemplos em contrário, talvez elas devam ser consideradas como fenômenos dignos de estudo. E o que essas intuições sugerem é que as pessoas tendem a aproximar-se do mundo em conformação com a visão clássica (mesmo se isso não acontece!). Assim, a visão clássica pode servir como uma metateoria (ou metafísica) dos conceitos para o leigo. ${ }^{97}$ (MEDIN; SMITH, 1984, p. 122-123, tradução nossa).

Opinião semelhante, formulada como crítica, é expressa por Lima (2011):

Além disso, tem-se a categorização cognitiva contemporânea - marcada, sobretudo, pela ausência de critérios rigorosos e pela noção contextual - que se fundamenta em um sujeito posto no mundo que comunga de interações em diversas arenas de socialização (a perspectiva epistemológica sociocognitiva). Isto concede à categorização cognitiva contemporânea um caráter variável e flexível, uma elasticidade e dinamicidade, marcada pela noção de contexto dependente.

Contudo, fica a inquietude sobre o papel que a categorização cognitiva contemporânea possa ocupar na BCI. Acredita-se que há de se manter uma postura reflexiva com relação à aplicação dessa perspectiva categorial de base, sobretudo, instável na área.

\footnotetext{
95 Rosch's theory of graded structure categorization, in its most general form, was that concepts and categories form to mirror real-world structure (of both perception and life activities) rather than logic. (GABORA; ROSCH; AERTS, 2008, p. 88).

${ }^{96}$ McNAMARA, T. P . ; STERNBERG , R. J. Mental models of word meaning. Unpublished manuscript, Yale Univ, 1983.

${ }^{97}$ The idea that object concepts do not have defining properties goes against many people's intuitions (see McNamara \& Sternberg 1983). Though these intuitions frequently will yield to counterexamples, perhaps they should be considered as phenomena worthy of study. And what these intuitions suggest is that people tend to approach the world as if it conformed to the classical view (even if it doesn't!). Thus, the classical view may serve as the layperson's metatheory of concepts (or the layperson's metaphysics). (MEDIN; SMITH, 1984, p. 122-123).
} 
Corrobora-se do entendimento contextual das categorias, mas entende-se que um SRI deve agregar uma noção categorial que transmita uma informação significativa a seu usuário. Se houver uma instabilidade muito grande nos métodos de organização, o alcance dessa informação significativa tende a se tornar mais suspenso e menos efetivo (LIMA, 2011, p. 311).

Contudo, apesar de qualquer crítica levantada, não é possível desprezar os resultados empíricos das pesquisas cognitivas modernas, o que abre o caminho para o segundo impasse: a necessidade de conciliar as duas vertentes.

As explicações propostas pelos modelos clássicos e de protótipo não são ainda consideradas satisfatórias. É muito difícil estabelecer linhas claras entre os pontos de vistas de cada modelo e os pontos em que são mais satisfatórios. Por um lado, o modelo clássico tem dificuldades em explicar os efeitos da tipicidade; por outro, os modelos alternativos não são capazes de explicar satisfatoriamente a organização das categorias, ou seja, o que faz com que as categorias sejam psicologicamente coesas. Talvez as diferentes naturezas das categorias resultem em tipos diferentes. Pode ser que existam categorias que se adequam melhor ao modelo clássico e outras, ao modelo de protótipo. (LIMA, 2010, p. 120).

Oliveira aprofunda a questão, colocando-a como o problema epistemológico "de conciliar a concepção clássica com as descobertas modernas a respeito dos conceitos" (OLIVEIRA, 1991, p. 86). Oliveira argumenta, apoiando-se em Medin e Smith, que os aspectos contextuais da teoria moderna e os aspectos reducionistas da teoria clássica dos conceitos não são, na verdade, incompatíveis.

Em seu livro Categories and concepts, Smith e Medin tomam emprestada de Miller e Johnson-Laird (17) a ideia de que um conceito tem dois aspectos, ou facetas, a saber um cerne ("core") - ao qual estão associadas as relações de um conceito com outros -, e um procedimento de identificação ("identification procedure") que entra em cena quando a questão é aplicar ou não um conceito a uma entidade percebida através dos sentidos. A sugestão de Smith e Medin para o problema da conciliação - sugestão que se tomou bastante popular entre os psicólogos - consiste na ideia de que os aspectos clássicos e modernos dos conceitos não são, na verdade, incompatíveis, e isto porque eles se referem a facetas diferentes dos conceitos, os aspectos clássicos refletindo, naturalmente, o cerne, e os modernos o procedimento de identificação. (OLIVEIRA, 1991, p. 86).

Lima é outra autora para quem "uma solução híbrida combinando o aspecto central com um processo de identificação do conceito pode ser ainda considerada a mais eficiente na categorização como um processo cognitivo" (LIMA, 2010, p. 120). Esta 
abordagem para o problema da conciliação, porém, na qual os conceitos têm uma natureza dupla, central e estável em seu cerne e outra instável e identificatória como processo, possui um viés que revela o uso de uma noção fraca de informação, uma vez que esta passa a ser julgada pelas suas qualidades de ser boa ou má para a estabilidade do cerne, ou seja, a desta apontar para estruturas mentais precisas. De fato, Oliveira (1991) propõe que os conceitos provem, essencialmente, da modularidade dessas estruturas mentais.

Os experimentos psicológicos que evidenciaram os aspectos modernos dos conceitos envolvem tarefas cognitivas que mobilizam várias faculdades mentais: a percepção, a imaginação, a memória, a inferência, a linguagem e outras. Se, à maneira de Fodor (em The Modularity of Mind $^{98}$ ) postularmos, em correspondência com cada uma dessas faculdades um módulo, então teremos um núcleo, um esboço de uma teoria sobre a estrutura mental. O que observações não sistemáticas indicam, e os experimentos psicológicos deixam patente, é que as entidades mentais a que chamamos conceitos participam de vários processos mentais diferentes. Tomemos, como exemplo, o conceito de cão. Este conceito entra em cena quando vejo um ser à minha frente e o identifico como um cão, quando imagino um cão, quando me lembro de um cão, quando faço a inferência que me leva de 'x é cão' a 'x é quadrúpede', etc. Um pressuposto não explícito, de boa parte das investigações que já foram feitas sobre conceitos, é o de que é uma mesma entidade mental - no caso, o conceito de cão - que participa de todos estes processos. A proposta de Smith e Medin dá um primeiro passo ao atribuir dois aspectos, ou facetas, a esta entidade. Nós vamos mais longe, primeiro afirmando que, em princípio, um conceito pode ter não apenas duas, mas várias facetas, cada uma correspondendo a um processo mental, e segundo, admitindo também a possibilidade de que não se trata na verdade de várias facetas de uma mesma entidade, mas sim de várias entidades diferentes, as quais têm entre si determinadas relações de correspondência. De acordo com este ponto de vista, o conceito de cão não designa uma entidade, mas sim uma família de entidades mentais, cada membro correspondendo a um módulo, ou, em outras palavras, cada membro representando um modo de ser do conceito, enquanto participante de cada tipo de processo mental. Uma consequência evidente deste ponto de vista é o princípio segundo o qual o estabelecimento da natureza dos conceitos pressupõe uma teoria sobre a estrutura e o funcionamento da mente humana. Ou seja, só podemos conhecer os membros de cada família de entidades mentais, que correspondem a um conceito, quando dispusermos de uma teoria que explique quantos e quais são os módulos de que se compõe a mente humana, como é o funcionamento de cada um deles, como eles se inter-relacionam, etc. (OLIVEIRA, 1991, p. 87).

\footnotetext{
${ }^{98}$ FODOR, J. The modularity of mind. Cambridge, MA: The Mit Press, 1983.
} 
Dessa perspectiva, a informação deixa de ser um processo de distinção, de realçar ou graduar diferenças, para ser um processo identificatório, contextual e instável, de referenciar representações/estruturas mentais. Deste modo, ficam deslegitimados os processos de categorização mais abstratos que se afastam do ato de identificar representações na mente. É por esta razão, por exemplo, que Eco lê em chave negativa os diversos recuos de Rosch em associar os efeitos de prototipicidade com a noção de representação.

[...] Eleanor Rosch, numa primeira fase de suas experiências (entre os anos 60 e 70), os protótipos são matéria de saliência perceptiva. Numa segunda fase (antes da metade dos anos 70), os efeitos prototípicos obtidos por experiência forneceriam uma caracterização da estrutura interna da categoria (de onde provém a persuasão de que constituem representações mentais). Numa terceira fase (fins dos anos 70), os efeitos prototípicos subdeterminariam as representações mentais, mas não haveria correspondência direta entre efeitos prototípicos e representações mentais. Eles não refletiriam a estrutura categorial. Portanto, conheceremos juízos de prototipicidade, mas eles não nos dizem nada sobre os nossos processos cognitivos, e os efeitos prototípicos seriam superficiais.

De fato, Rosch (1978: 174 segs.) esclarece que o protótipo não é nem membro de uma categoria nem uma estrutura mental precisa, quanto mais o resultado de uma experiência que tem em vista recolher e quantificar juízos sobre o grau de prototipicidade [...]. (ECO, 1998, p. 170-171).

Eco, assim como os autores citados anteriormente, parecem pressupor vastas ordenações de representações, estáveis e acumuladas na mente. Embora Eco tenha argumentado que estas representações (como Tipos Cognitivos / TCs e Conteúdos Nucleares / CNs compartilhados em comum) sejam sempre negociáveis na práxis comunicacional, também argumenta que, enquanto categorias, possuiriam caráter instrucional.

Em qualquer ordenação categorial, o gênero superordenado deve ter menos traços que a espécie subordinada, e a espécie menos ocorrências individuais que permite reconhecer. Se o TC para o cão fornecesse instruções para construir um pequinês e nada mais, dificilmente seria aplicável a um maremano. Se um protótipo (lá onde já ajustamos um sistema classificatório) e um TC tivessem algo em comum, seria que ambos deveriam ter uma extensão máxima e intensão mínima. Ao invés disso, o protótipo possui extensão mínima e intensão máxima. (ECO, 1998, p. 171).

O caráter instrucional dessas categorias de base talvez seja o que garante, sob o ponto de vista representacionista, a "coesão psicológica” (expressão de Lima, 2010) da 
abordagem clássica dos conceitos, e o que garante aos conceitos uma natureza de "unidade" ou mesmo serem tratados como uma unidade, como o faz Dahlberg. Ainda sob o ponto de vista deste "caráter instrucional", caberia aos processos identificatórios assinalar os limites dessas instruções, assim como na noção fraca de informação cabe a esta suprir as lacunas na falta de informação que ainda não foi "capturada" do ambiente ou do "continuum indiferenciado", via percepção.

Parece-me que a noção de protótipo tenha um valor para esclarecer quais são as "margens" de uma categoria de base: se decidimos que os traços salientes da categoria superordenada dos pássaros são bico, plumas, asas, duas patas e a capacidade de voar, é natural que haja embraço para definir plenamente como pássaro a galinha, que não voa, mas que, no máximo, bate as asas (e não a excluímos, porque admitimos que os outros pássaros também não deixam de ser pássaros mesmo quando não voam). Mais discutível parece a identificação do protótipo de forma positiva, porque acredito que dependa de experiências ambientais e que os juízos de prototipicidade tenham mais valor para uma pesquisa de antropologia cultural que para determinar mecanismos cognitivos em geral. (ECO, 1998, p. 171).

Esta posição de Eco revela, porém, algumas proposições que tínhamos descartado e uma contradição profunda: propõe que existem categorias de base derivadas de mecanismos cognitivos que não interagem (por serem de natureza perceptiva) com escolhas e preferências culturais (e assim, em última instância, com a linguagem), o que entra em contradição com a ideia de que TCs e CNs não correspondem a entidades fixas, portanto, seriam sempre negociáveis na práxis comunicativa. Essas proposições encontram algumas dificuldades. A primeira, a de uma suficiência da percepção para conformar TCs: como discutimos anteriormente, a percepção não oferece inputs suficientes para a percepção de qualquer tipo de "campo estimulante", assim como o armazenamento ilimitado de TCs definidos (a ideia de "possuir TCs", repetida por Eco) encontra dificuldades nas características recursivas e composicionais do cérebro. De fato, recuperar itens da memória pouca semelhança tem com recuperar itens numa enciclopédia. Enquanto a imagem de um vaso de flores numa enciclopédia possui unidade (sobre o papel), a imagem que vemos provém de um cérebro que sincroniza disparos neurais a cada vez que surge o estímulo(s).

Algumas evidências indicam que o tempo sincronizado - com cada pico representando um aspecto de um objeto (cor ou orientação) - funciona como um meio de composição de uma imagem a partir de partes constituintes. Um pico para "vermelho-rosado" dispara em 
sincronia com um de "contorno redondo", permitindo que o córtex visual mescle esses sinais na imagem reconhecível de um vaso de flores. (SEJNOWSKI; DELBRUCK, 2012, p. 57).

Ou seja, o "TC" do vaso de flores não está realmente "lá", de algum modo, em algum lugar da mente, mas é recursivamente composto milissegundo a milissegundo pelo disparo coordenado de picos diferentes entre neurônios (aspectos), que só formam "propriedades" enquanto disparam em sincronia perfeita - e mesmo a memória destas depende dessas coordenações sincrônicas. É essa coordenação sincronizada, recursivamente retomada, que assegura uma percepção estável, e não os estímulos perceptivos que oferecem coerência às "estruturas mentais". Pelo contrário, estímulos sensoriais são desorganizados por virem através de estruturas muito diferenciadas e espalhadas; as "células cerebrais recebem todos os tipos de estímulos em escalas de tempos diferentes. O sinal de um microssegundo na orelha direita deve ser conciliado com a entrada um pouco fora de sincronia na esquerda" (SEJNOWSKI; DELBRUCK, 2012, p. 54). E a integração de todas essas informações, como explicamos com Tononi, não provém desde elementos básicos, mais simples e extensivos, que serviriam de instrução para a construção de categorias mais complexas de maior intensão, mas são integradas em direção às experiências elementares. A ideia de que existe uma separação entre cognição e interpretação, a primeira tributária das percepções e a segunda livre de restrições por ser construída como juízos, leva a um duplo engano: a de que interpretações culturais não têm peso cognitivo e a de que experiências perceptivas têm sempre sua origem num continuum externo ao indivíduo. Este duplo engano se assenta, de fato, na necessidade de assegurar alguma coesão psicológica intersubjetiva àquilo que é produzido semioticamente.

Portanto, mesmo se admitíssemos que cada sistema cultural e cada sistema linguístico em que ele se apoia segmentam o continuum da experiência de modo próprio (Davidson falaria de "esquema conceitual"), o que não exclui que o continuum organizado por sistemas de proposições se nos ofereça já segundo linhas de resistência que fornecem diretivas para uma percepção intersubjetivamente homogênea, mesmo entre sujeitos que voltam a diferentes sistemas de proposições. (ECO, 1998, 217).

O argumento de Eco é uma versão mais elaborada e sutil da noção comum de que simplesmente são as coisas que nos informam sobre elas, em sua inteireza, a qual ele troca por uma abordagem mais minimalista em que o continuиm delineia categorias básicas, como a noção de redondo, ou pré-categoriais/pré-semióticas (ou primitivos 
semióticos) como a sensação de um vermelho ou branco puros. Decerto que é necessário alguma intersubjetividade, no sentido em que dois indivíduos precisam ter a segurança de que estão observando a mesma coisa, mas colocar essa segurança na presunção de que o meio pode ditar, mesmo que indiretamente, a organização do sistema nervoso leva a uma negação do conceito de evolução biológica. Ora, se é o meio que está configurando a percepção, então também está configurando as estruturas adaptadas a esse meio, portanto, para cada meio caberia apenas um tipo de adaptação, uma espécie apenas! É só olhar para qualquer nicho ecológico para observar que das mesmas variáveis ambientais brotam as mais diferentes adaptações, de dezenas a centenas de espécies por nicho.

Se existe alguma intersubjetividade "homogênea", ela não provém desde fora, mas pertence à espécie, num processo que Maturana e Varela (2002) chamaram de deriva natural, isto é, o compartilhamento hereditário da autoprodução de estruturas em comum para lidar com o ambiente. Se percebemos o sangue como um vermelho-vivo é porque isso foi selecionado como vital, numa espécie de pele fina perceber o próprio sangramento em si, e nos outros, é de vida ou morte. Para um tubarão, por outro lado, é mais interessante sentir o cheiro do sangue na água, uma experiência que nenhum ser humano será capaz de ter. Dizer que o sangue possui em suas moléculas linhas de resistência que guiaram a adaptação perceptiva dessas duas espécies é inverter o raciocínio da adaptação biológica. De fato, as linhas de resistência estão no organismo, na adaptação que estrutura, a par de $n$ fatores relevantes, uma qualificação da percepção e, por conseguinte, da experiência. Conseguir mudar ou não uma qualificação perceptiva depende do quanto esta possui como valor de sobrevivência, e não a par de diretivas rígidas contidas no "continuum". Não é possível cancelar o gosto ardido das pimentas, mas quem nasce em culturas que as apreciam consegue mudar uma qualificação de desagradável (rejeição de algo possivelmente venenoso) para saboroso e com isso conseguir descobrir que os alimentos podem ser conservados por elas.

O aprendizado não deriva, portanto, da percepção, mas da interação com uma qualificação, que pode ser reforçada, mudada ou negada, dentro dos limites da história estrutural do organismo. Não se trata de ficar imaginando se o sabor ardido da pimenta pode ser uma Primeiridade, a comparação com outros gostos uma Secundidade, e o juízo a "pimenta é ardida" é uma Terceiridade, mas como a interação com uma qualificação modifica a experiência. Dizer a "pimenta é ardida" terá um peso em 
Buenos Aires e outro em Calcutá. O peso desse sentido não é trivial, mas isso não será entendido enquanto se fizer uma divisão entre experiências perceptivas e experiências interpretativas, em que estas últimas precisam se justificar em razão das primeiras. Se Eco tivesse que descrever o vaso de flores, e estas fossem rosas, diria que primeiro existe a sensação do vermelho, depois o enquadramento em categorias básicas para as formas das pétalas, a forma de cilindro do vaso (o enquadramento tridimensional), para só depois virem os juízos perceptivos "isto é um vaso", "contém rosas", e culturalmente recortados "rosas são bonitas para mulheres", "vasos de flores ficam bem na varanda". Se aplicássemos a abordagem de Tononi haveria uma reversão: a experiência do vermelho estaria no topo, e o qualia desta cor estaria correlacionado com todas as outras distinções realizadas, a forma das pétalas, do vaso, a posição, onde está, quem o segura, em que sociedade estamos, como as mulheres qualificam as rosas, quem não gostas das rosas como presente, e assim prosseguiria, de rede em contextual em rede contextual de acordo com o nível de discriminação.

Esta última abordagem seria através da noção forte de informação, na qual a informação constrói tanto as experiências perceptivas quanto as interpretativas. É também sistêmica, porque leva em consideração como ela transforma, e se transforma, enquanto regime de admissão de diferenças através dos sistemas considerados (perceptivos/psíquicos $\rightarrow$ comunicacionais/sociais). Para que essa noção seja aplicável aos conceitos é necessário que o "problema da conciliação" seja recolocado em outros termos, em que o fenômeno da contextualidade (abordagem prototípica) e as operações de definibilidade dos conceitos (teoria clássica) não sejam simples facetas de uma natureza fixa dos conceitos (um núcleo mais o procedimento identificador). Essa última abordagem leva os conceitos a ficarem, na prática, isolados dos fluxos dinâmicos da comunicação, uma vez que o aspecto contextual fica amarrado a uma concepção dualista de mente, entre a que captura representações através da percepção e a que cria representação através da interpretação, sendo que estas interpretações terão que se justificar, em algum momento, a partir das representações perceptivas. Deste modo, pouco se avança em relação a definições já repetidas sobre os conceitos, como as de Dahlberg de que estes são sínteses fixadas em denominações que predicam verdades sobre os objetos no mundo ou unidades de conhecimentos compostas por predicados verificáveis sobre esses objetos (DAHLBERG, 1976, 1978). 
O que falta a estas abordagens e pontos de vista é colocar os conceitos em relação aos objetos e ou fenômenos que pretendem representar ou indicar. Mais do que isso, entender qual a relação recíproca entre conceitos e mundo. Se o conceito tem um uso, então ele tem um efeito, que por sua vez retroage sobre o conceito. Retomando o conceito de adaptação biológica, as espécies se diversificam a partir de um mesmo meio, mas modificam esse meio através da diversificação (introduzem novas substâncias e relações), alterando-o para algo mais complexo e diversificado que, por sua vez, dispara novas adaptações, criando assim uma reciprocidade ecológica. Podemos pensar nos conceitos como qualificações do mesmo meio (psíquico/social) que os origina, portanto, ensejando modificações neste, o que por sua vez muda as condições que geram estes conceitos. É nesse sentido que a teoria ecológica dos conceitos (GABORA; ROSCH; AERTS, 2008) demonstra sua pertinência, ao pautar os conceitos como participantes daquilo que definem ou apontam. Os autores reportam que essa perspectiva não é nova, e que em psicologia da percepção ela despontou primeiramente com Gibson. Para Gibson, a percepção de si mesmo e do ambiente são, por definição, inseparáveis, "e os supostamente separados domínios da objetividade e da subjetividade são na verdade apenas pólos de atenção"99 (GIBSON apud GABORA; ROSCH; AERTS, 2008, p. 94). Gibson é também o introdutor do termo affordances (fornecimentos, em uma tradução aproximada) cujo conceito explica que o ambiente fornece funções para a ação do organismo, por exemplo, o chão fornece sustentação, lugares fechados fornecem abrigos, objetos alongados fornecem a possibilidade de furar ou espetar, mas estas funções são inseparáveis da co-definição entre o sujeito que percebe e o objeto percebido. Ou seja, o ato de jogar algo complementa o ato de perceber objetos arremessáveis. Contudo, ponderam os autores, ainda assim parece bastante óbvio que o observador e o mundo percebido são concebidos como diferentes e separados, e perguntam: por quê?

É aqui que nós vemos que os conceitos entram para compor o quadro. Aplicar uma abordagem ecológica aos conceitos e não aos perceptos pode parecer incomum. No entanto, acreditamos que a distinção entre percepções e conceitos pode refletir o que o pesquisador ou observador está focado, mais do que refletir o que está acontecendo para o participante [pesquisador/observador]. Mais importante ainda, é somente quando os objetos no mundo forem conceitualizados é que eles são carregados com o potencial de

\footnotetext{
${ }^{99}$ The supposedly separate realms of the subjective and the objective are actually only poles of attention.
} (GIBSON apud GABORA; ROSCH; AERTS, 2008, p. 94). 
interagir dinamicamente de inúmeras formas com as concepções de outros objetos, bem como com os objetivos, planos, esquemas, desejos, atitudes, fantasias e assim por diante, que constituem a vida mental humana. E é através dessas interações que as suas relações são discernidas e assim, conjuntamente, passam a funcionar como um modelo interno integrado do mundo, ou visão-de-mundo. É quando estímulos no mundo são compreendidos em termos conceptuais que eles adquirem uma estrutura weblike [tipo-rede], e uma autoorganização dinâmica característica de uma ecologia. Por isso, é nossa opinião que um tratamento ecológico dos conceitos abre a possibilidade de tornar não só as ações, mas também o pensamento complexo, passível de uma abordagem mais ecológica, como sugeriu Gregory Bateson (1973) tempos atrás. Rosch (1999) defendeu que é papel dos conceitos prover uma ponte entre o que nós pensamos ter na mente e o que pensamos estar no mundo, e ter articulada esta posição em termos de suas implicações para os conceitos. Conceitos e categorias não representam o mundo na mente, como é geralmente assumido, mas são parte participante do mundo e da mente como um todo. Por este motivo, eles apenas ocorrem como parte de uma rede de significados provida, ao mesmo tempo, por outros conceitos e pelas inter-relações na vida cotidiana. Isto significa que conceitos e categorias existem somente em complexas situações concretas. ${ }^{100}$ (GABORA; ROSCH; AERTS, 2008, p. 95, tradução nossa).

A abordagem ecológica dos conceitos, por colocar sua ênfase nos processos de foco do observador, é condizente com nossa opção de análise de formação dos conceitos sob o crivo da noção forte de informação. Por esta propomos que a formação dos conceitos se apóia, fenomenologicamente, na distinção como processo de diferenciação (formar informação), e distinguir é um processo relativo ao foco do observador. Enquanto a noção fraca de informação propõe um relativismo extremo (tudo é informação), e ela é fraca justamente por causa da falta de demarcações de sua

\footnotetext{
${ }^{100}$ This is where we see concepts coming into the picture. To apply an ecological approach to not percepts but concepts may seem unusual. However, we believe that the distinction between percepts and concepts may reflect what the researcher or observer is focused on as much as it reflects what is happening for the participant. More importantly, it is only when objects in the world have been conceptualized that they are charged with the potential to dynamically interact in myriad ways with conceptions of other objects as well as with the goals, plans, schemas, desires, attitudes, fantasies, and so forth, that constitute human mental life. And it is through these interactions that their relations are discerned, and together they thereby come to function as an integrated internal model of the world, or worldview. Thus it is when stimuli in the world come to be understood in conceptual terms that they acquire the weblike structure and self-organizing dynamics characteristic of an ecology. It is therefore our view that an ecological treatment of concepts opens up the possibility of making not just action but also complex thought processes amenable to a more ecological approach, as suggested by Gregory Bateson (1973) sometime ago. Rosch (1999) argues that it is the role of concepts to provide a bridge between what we think of as mind and what we think of as world, and has articulated this position in terms of its implications for concepts. Concepts and categories do not represent the world in the mind, as is generally assumed, but are a participating part of the mind-world whole. Therefore, they only occur as part of a web of meaning provided both by other concepts and by interrelated life activities. This means that concepts and categories exist only in concrete complex situations. (GABORA; ROSCH; AERTS, 2008, p. 95).
} 
manifestação fenomenológica, a noção forte é contextualmente relativa, demarcando sistemicamente a relação observador-mundo. Essa demarcação sistêmica, como a conformação da mente enquanto sistematização das relações do observador com seu meio, se beneficia da compreensão de como o foco do observador, focando ou desfocando modos de distinguir diferenças, cria regimes de manutenção desses focos (regimes de admissão de diferenças) e, assim, cria os próprios limites sistêmicos dessa relação observador-mundo. Esse contingenciamento sistêmico da observação, se abordado apenas pelos seus aspectos sincrônicos, fornecerá, porém, uma compreensão muito limitada da formação dos $\operatorname{conceitos}^{101}$, uma vez que não seria abordada a coevolução entre observador e meio observado. Esse é um aspecto negligenciado na abordagem clássica dos conceitos, que privilegia os aspectos sincrônicos das relações de representação.

$\mathrm{Na}$ abordagem clássica, por exemplo, categorias e conceitos possuem um significado frequentemente intercambiável, que negligencia os efeitos da evolução cultural sobre os aspectos cognitivos da abstração. Obviamente, tais efeitos não podem ser estimados se considerarmos que os aspectos cognitivos dos conceitos e das categorias são o que são desde sempre, ou que as mudanças culturais desde o tempo dos caçadores-coletores até os gregos nada significaram em relação a como o observador constrói os conceitos. É preciso, portanto, adicionar a perspectiva evolutiva sobre a questão da formação dos conceitos, que está contemplada na abordagem ecológica dos conceitos justamente porque a integração de conceitos de forma a configurar redes conceituais (visões-de-mundo) não é possível de compreender sem incluir como a capacidade de focar a observação evoluiu em nossa espécie (homo sapiens sapiens).

A partir da abordagem ecológica dos conceitos, essa perspectiva evolucionista aparece desenvolvida em Gabora e Aerts (2009), estudo no qual se analisa a transição entre modos mais primitivos de pensamento, referidos como episódicos e miméticos (imitativos) e o modo moderno, de integração de conceitos em níveis mais abstratos de elaboração. A mente episódica seria relacionada a categorizações situacionais, como amigo/inimigo, alimento/não alimento (sem direcionar estas categorias a palavras). Todavia, se a mente episódica fosse capaz de associar memórias, ligadas a contextos

\footnotetext{
101 Esta pode ser uma razão para não se ter encontrado no Corpus desta pesquisa trabalhos que contemplassem fenomenologicamente a formação dos conceitos; um corte diacrônico exigiria pensar a questão da evolução da cognição, e a maioria dos trabalhos possuía um recorte temático sincrônico, isto é, considerava essa formação como uma derivação da cognição como está dada atualmente.
} 
situacionais externos, não seria capaz de engajar associações espontâneas de memórias, para o que um contexto gerado internamente seria necessário. Isto significa que sem uma cadeia de memórias espontaneamente associadas não é possível o surgimento de uma corrente recursiva autossustentada de pensamentos. Por essa razão "a mente episódica dos primeiros hominídeos tendia a não se desviar do 'aqui e agora' dos episódios percebidos, o oposto de um mundo de construtos mentais e imaginação" 102 (GABORA; AERTS, 2009, p. 23, tradução nossa).

A transição entre a mente episódica e a mimética se daria em torno de 1,7 milhões de anos atrás, quando houve um súbito aumento no tamanho do cérebro, portanto, na capacidade das sinapses em criar memórias mais detalhadas e interconectadas, permitindo à mente mimética poder acessar memórias independente de pistas externas e representá-las, agrupando episódios em conjuntos como instâncias de conceitos abstratos, refinando ideias, e melhorando habilidades através de repetição e ensaio (GABORA; AERTS, 2009). Isto pode parecer, à primeira vista, a descrição de hábitos mentais modernos, mas o que faltava nesse estágio evolutivo era, além de acessar memórias independentemente do contexto imediato, possibilitando associar conceitos, era associar contextos diferentes de forma a gerar modelos coerentes de aspectos díspares do mundo. Isto é, a mente mimética era capaz de abstração e planejamento, mas ainda estava presa a seguir as mesmas trilhas contextuais (imitação), ou similares. Por exemplo, o conceito BÚFALO podia ser associado em suas várias instâncias, búfalos grandes, pequenos, fêmeas, com o contexto PERIGO, em suas várias gradações, como perigo iminente, cuidado, perigo distante, e também associado a contextos similares como CAÇA ou ALIMENTO. Mas não seria associado com contextos alheios àqueles em que BÚFALO aparece como instância de uma série similar de contextos, porque não existe ainda a capacidade de focar contextos diferentes ao mesmo tempo (como ocorre com os conceitos). Assim, BÚFALO como instância do contexto RELAÇÕES PESSOAIS, em "Og é um búfalo" demandaria focar/desfocar vários contextos diferentes (APARÊNCIA PESSOAL, STATUS SOCIAL, STATUS SEXUAL, e assim por diante) para ser coerente. A semelhança desse processo com a linguagem não é coincidência. A linguagem para Maturana e Varela (2002) se realiza através de coordenações mais abrangentes, nas quais contextos tornam-se instâncias de

${ }^{102}$ For this reason, the episodic minds of early hominids tended not to deviate far from the 'here and now' of perceived episodes, as opposed to the world of mental constructs and imagination. (GABORA; AERTS, 2009, p. 23). 
outros contextos, e ela não está necessariamente presente quando se repete a coordenação de uma ocorrência (como quando se coordena um gesto enfático específico para simbolizar que um búfalo grande - perigoso - está por perto, e este é apenas repetido na repetição desse contexto).

Embora não se afirme aqui que a linguagem nasceu exatamente na transição entre a mente mimética e a moderna, Gabora e Aerts colocam essa transição na época em que o registro arqueológico revela uma explosão de criatividade cultural, entre 60 e 30 mil anos atrás, e, citando Mithen $(1996){ }^{103}$, afirmam que este período se refere "ao 'big-bang' da cultura humana, reivindicando que este marca o início das artes, ciência e religião, e que mostrou mais inovações do que os prévios seis milhões de anos de evolução humana"104 (GABORA; AERTS, 2009, p. 28, tradução nossa). Os autores propõem que essa transição ocorreu através da ampliação da capacidade de separar processos cognitivos, como duas formas de pensamento, ou que o pensamento varia ao longo de um continuum entre dois extremos.

Em uma das pontas finais desse continuum está o modo analítico de pensamento, conduzindo para deduções e descrições e analisando relacionamentos de causa e efeito. $\mathrm{Na}$ outra ponta final do continuum esta o modo intuitivo, super-inclusivo, ou associativo de pensamento, que conduz a discriminar relacionamentos sutis; isto é, conexões entre itens que estão correlacionados, mas não necessariamente casualmente relacionados. ${ }^{105}$ (GABORA; AERTS, 2009, p. 29, tradução nossa).

Associamos estes modos aos regimes sistêmicos de informação explicados no capítulo precedente, em que o modo analítico corresponde aos regimes redutivos de informação e o modo associativo aos regimes expansivos. Na análise de Gabora e Aerts este último modo possui maior preponderância (diríamos que é um modo de partida), e as características a ele atribuídas condizem igualmente com os atributos de um regime expansivo da informação.

\footnotetext{
${ }^{103}$ MITHEN, S. The prehistory of the mind: a search for the origins of art, science, and religion. London: Thames \& Hudson, 1996.

${ }^{104}[\ldots]$ as the 'big bang' of human culture, claiming that it marks the beginning of art, science, and religion, and that it shows more innovation than the previous six million years of human evolution. (GABORA; AERTS, 2009, p. 28).

${ }^{105}$ At one end of the continuum is an analytic mode of thought conducive to deduction and to describing and analyzing relationships of cause and efect. At the other end of the continuum is an intuitive, overinclusive, or associative mode of thought conducive to finding subtle relationships; i.e. connections between items that are correlated, but not necessarily causally related. (GABORA; AERTS, 2009, P. 29).
} 
Neste modo, itens são representados não só em termos de suas propriedades mais típicas, mas também em termos das menos típicas, assim como nas contexto-dependentes também. Pensamentos associativos são relacionados com a noção de hierarquias associativas horizontais, em que um termo é dado não somente a itens típicos mas também àqueles marginais ou atípicos por quem é inquirido a dizer qual palavra vem à mente em resposta a uma palavra em particular, por exemplo, AVESTRUZ em resposta a PÁSSARO, ou PUFE (Puffs) em resposta a CADEIRA. ${ }^{106}$ (MEDNICK, 1962, apud GABORA ; AERTS, 2009, p. 29, tradução nossa).

Compreender o modo associativo como mais fecundo e fundamental não explica tudo, já que nos estágios anteriores (ao Homo sapiens) ele também existia. A diferença tem que estar no tipo de coexistência com o modo analítico. Se antes da transição para o pensamento moderno eram as situações que levavam o pensamento para um modo ou outro (impedindo uma maior intervenção criativa), com o Homo sapiens é o pensamento que conduz as situações ao alternar os modos de pensar. Isto é conseguido, segundo Gabora e Aerts, “[...] através de surtir um foco contextual: a capacidade para espontaneamente focar ou desfocar a atenção em resposta à situação corrente [...]"107 (GABORA, AERTS, 2009, p. 29, em tradução livre). A diferença está nessa alternância espontânea, o que permite optar como diferenças deverão ser admitidas na distinção, criando regimes distintos, mas complementares, que permitem, por sua vez, expandir a qualificação de uma experiência (criar associações) ou reduzir essa qualificação (definir e separar para abstrair ou analisar). Deste modo, a formação de um conceito ganha mobilidade contextual, suas propriedades tanto podem participar de um contexto quanto de outro, é apenas a transição entre os focos que nos fará dizer "ele está definido", "ele está indefinido". A partir de um regime redutivo de informação, propriedades fazem ou não fazem parte de um conceito (definindo-o ou indeterminando-o), propriedades conflitantes ou contraditórias fazem parte do modo de qualificar desse regime, assim como a sensação de que um conceito possui "unidade". Mas esse regime, se levado ao extremo do continuum cognitivo, provocaria um enrijecimento tal dos conceitos que travaria qualquer possibilidade de composicionalidade. Contudo, a composicionalidade

\footnotetext{
${ }^{106}$ In this mode, items are represented in terms of not just their most typical properties but also in terms of less typical, perhaps context-dependent ones as well. Associative thought is related to the notion of at associative hierarchies, a term applied to those who give not only typical but also marginal or atypical items when asked to say words that come to mind in response to a particular word, e.g. OSTRICH in response to BIRD, or BEANBAG CHAIR in response to CHAIR. ${ }^{106}$ (MEDNICK, 1962, apud GABORA ; AERTS, 2009, p. 29).

${ }^{107}$ [...] through the onset of contextual focus: the capacity to spontaneously focus or defocus attention in response to the current situation. (GABORA; AERTS, 2009, p. 29).
} 
através da simples tolerância ao conflitante ou contraditório é apenas um procedimento nos limites do regime. Marco Polo não consegue uma síntese aceitável ao combinar propriedades rudes do rinoceronte (pele, língua e unhas ásperas) com as propriedades refinadas do unicórnio tradicional. Compor um ornitorrinco através de partes de outros animais (bico de pato, nadadeiras, corpo e cauda de castor) também não parece procedente. Dizer que é preciso segmentar de novo o continuum não indica um procedimento, apenas o limite do regime inclusão/exclusão de diferenças. É preciso voltar a um ponto do continuum cognitivo em que as diferenças já não são tão marcadas, em que elas se expandem, isto é, é preciso desfocar a atenção abstrativa, permitindo uma recomposição dos constituintes do conceito.

A mente moderna possui a habilidade de mudar entre pensamentos analíticos, conduzindo primariamente à realização de relacionamentos entre estados de conhecimentos conhecidos, e pensamentos associativos, conduzindo primariamente a forjar novos conceitos através da formação de conjunções, as quais são estados de emaranhamento do resultado da aplicação do produto tensor dos espaços de Hilbert dos dois constituintes do conceito. ${ }^{108}$ (GABORA; AERTS, 2009, p. 39, tradução nossa).

Estando o processo proposto por Gabora e Aerts, de emaranhamento entre estados diferentes dos constituintes de dois conceitos (ou mais, talvez), na raiz do processo de constituir conceitos novos, então esse é o processo (digamos natureza) dos conceitos em si, uma vez que sem o novo nada continua, ou se inicia. Esse processo é semelhante ao descrito por Tononi na formação de correlações entre complexos de informação integrada, que por sua vez formam os qualia informativos que qualificam a experiência (e geram o conhecimento desta). Esse estado de emaranhamento entre os complexos constituintes de informação integrada se desfeitos (ou decaídos, no jargão da física quântica) formariam um isolamento entre os complexos (levariam a um decaimento para propriedades mais simples destes), desmoronando a estrutura do qualia, assim, interrompendo uma ponte entre cognição e experiência. Analogamente, conceitos são, antes de tudo, uma integração entre possibilidades de sentido, plenamente participantes da experiência (constroem-na continuamente), mas não necessariamente eficazes ou justificáveis. É o foco do observador que cria a

${ }^{108}$ The modern human mind has the ability to shift between analytic thought, conducive primarily to realizing relationships amongst states of a known concept, and associative thought, conducive primarily to forging new concepts through the formation of conjunctions, which are entangled states that result through application of the tensor product of the Hilbert spaces of the two constituent concepts. (GABORA; AERTS, 2009, p. 39). 
justificativa, que faz as ligações de causa e efeito que, se não encontradas, obriga de novo a consciência a desfocar, a afrouxar os limites, de modo a que ocorra uma expansão em direção a uma nova forma de compreensão. Um exemplo dessa abordagem de conceito já foi preliminarmente explicado, através do conceito "homem feminino": o conceito integra um $n$ número de sentidos ( $\rightarrow$ "homem com aparência feminina"/"homem com trejeitos femininos"/“homem sem aparência feminina, mas delicado" $\rightarrow$ ), cujas associações são regidas pelo estado de emaranhamento, ou seja, ao estimar o peso de qualquer uma destas associações provocaríamos um decaimento para aquele valor considerado. A variável $n$, portanto, é um artifício, já desde um regime redutivo, e a eleição, por exemplo, de algum item da sequência aqui colocada entre flechas é o que Gabora e Aerts denominariam de "estado básico ou fundamental" (ground state) de um conceito, um estado 'bruto' ou 'não distribuído' deste, que não participa da estruturação de uma experiência consciente.

$\mathrm{O}$ estado fundamental é um estado em que nenhum contexto interage com ele. Ninguém experimenta um conceito em seu estado fundamental, este é sempre evocado em algum contexto. O estado fundamental é uma construção teórica; não pode ser observado diretamente, mas apenas indiretamente através de como o conceito interage com outros contextos (o que inclui outros conceitos). Isto é análogo ao fato que sistemas físicos nunca estão em um espaço vazio. ${ }^{109}$ (GABORA; AERTS, 2009, p. 7, tradução nossa).

Este estado é equivalente ao que na teoria clássica do conceito aparece como "unidade mental" ou "unidade de conhecimentos". Na abordagem clássica, o conceito é definido por uma série de relações lógicas, mas o que nos interessa abordar aqui é quando um conceito se torna muito complexo ao tentar dar conta de muitas relações nessa estrutura, ao ponto que o foco do observador se vê obrigado a tecer inter-relações entre os conceitos, formando um 'sistema de conceitos', como sugere Dahlberg (1978a). Isso é derivado do intercambiar entre focar/desfocar a atenção, o que propicia uma recursividade dentro das estruturas conceituais, como explicam Gabora e Aerts:

[...] o pensamento analítico permite a identificação de relacionamentos causais, enquanto pensamentos associativos facilitam reconhecer itens na memória que estão correlacionados, isto é, que

\footnotetext{
109 The ground state is the state of being not disturbed at all by the context. One never experiences a concept in its ground state; it is always evoked in some context. The ground state is a theoretical construct; it cannot be observed directly but only indirectly through how the concept interacts with various contexts (which may include other concepts). This is analogous to the fact that a physical system is never in empty space. (GABORA; AERTS, 2009, p. 7).
} 
compartilham propriedades, as quais, por seu turno, provêm mais ingredientes para o pensamento analítico. ${ }^{110}$ (GABORA; AERTS, 2009, p. 39, tradução nossa).

Essa mobilidade permite a existência de "visões-de-mundo com uma estrutura hierárquica de forma recursiva incorporada e conceitos de variados níveis de abstração, pavimentando o caminho para a integração conceitual"111 (GABORA; AERTS, 2009, p. 29, tradução nossa). Com essa integração inflando, a mudança na natureza do foco provoca uma mudança sistêmica, uma vez que a atenção do indivíduo alcança um limite. Este é o limite do sistema psíquico, em que o foco precisa ceder para interagir em uma escala maior.

Muitas espécies podem aprender, imitar, lembrar, e talvez até formar conceitos. Assim, a capacidade de focar e desfocar pode ser o passo chave na obtenção de uma linguagem complexa, religião, ciência, arte e outros aspectos da cultura que nos fazem únicos. Desfocar o pensamento forja conexões entre itens que partilham uma estrutura profunda, mas que são superficialmente independentes. Desde que essas relações são frequentemente difíceis de encontrar, o aprendizado cultural também joga um papel chave aqui, preenchendo as ligações perdidas que a criança não consegue achar por ela mesma (talvez a grande maioria). Porque a maioria dos frutos de tais achados criativos são culturalmente transmitidos, não é necessário que cada indivíduo gere uma visão-de-mundo do zero. Os conceitos ou ideias mais duramente obtidos precisam apenas encontrar sua realização num só indivíduo; os outros membros da sociedade obtêm-na 'de graça' sem qualquer pensamento particularmente focado/desfocado. ${ }^{112}$ (GABORA; AERTS, 2009, p. 40, tradução nossa).

Os conceitos sofrem uma mudança de organização no continuum cognitivo quando precisamos compartilhar com os outros nosso foco sobre eles. Os regimes expansivos e redutivos ganham uma natureza interacional que influi sobre os próprios mecanismos cognitivos de elaboração conceitual. Quando relaxamos nossa atenção em

\footnotetext{
${ }^{110}$ Analytic thought enables the identification of causal relationships, while associative thought facilitates recognition of items in memory that are correlated, i.e. that share properties, which in turn provides more ingredients for analytic thought. (GABORA, AERTS, 2009, p. 39).

${ }^{111}[\ldots]$ A worldview with recursively embedded hierarchical structure and concepts of varying levels of abstraction, which paved the way for conceptual integration. (GABORA, AERTS, 2009, p. 29).

${ }^{112}$ Many species can learn, imitate, remember, and perhaps even form concepts. So this capacity to focus or defocus may be the key step in the attainment of complex language, religion, science, art, and other aspects of culture that make us unique. Defocused thought forges connections amongst items that share a deep structure but are superficially unrelated. Since these relations are often difficult to find, cultural learning also plays a key role here, filling in the missing links that the child does not find on its own (perhaps the vast majority). Because most of the fruits of such creative achievements are culturally transmitted, it is not necessary that we each individually generate an interconnected worldview from scratch. A hard-to-come-by concept or idea need only be realized in the mind of one individual; the other members of a society get it 'for free' without any particularly focused or defocused thought. (GABORA; AERTS, 2009, p. 40).
} 
conjunto com outros, abrimo-nos para as possibilidades de inclusão de sentidos alheios (até incompreensíveis), e quando focamos nossa atenção conjuntamente dirigimo-nos justamente na direção contrária, de podar sentidos que não se coadunam com distinções anteriores. O que se adiciona à elaboração conceitual, portanto, é a dimensão social, que passa a ser regulada por esse processo de expansão/constrição; a comunicação como o compartilhamento comum de temas é o resultado desse processo, e não o seu núcleo condutor. A tese de Luhmann é justamente de que a comunicação se organiza em torno de um procedimento binário (negar/conceder) de qualificação dos temas, em que estes vivem e morrerem em função da valoração negativa ou positiva que ganham socialmente, conformando, assim, sistemas sociais fechados de valoração. De fato, manter visões-de-mundo coesas através da aprendizagem social requer energia, e podese economizar essa energia num regime de informação reducionista, que passa à frente um número limitado de opções de sentido, mas com um algoritmo capaz de lidar com um sem-número de desvios, mantendo, desse modo, o fechamento do sistema. Contudo, todo sistema social precisa se manter fecundo, como qualquer sistema vivo, para manter sua integridade ao mesmo tempo em que se permite evoluir. Por isso, todos os sistemas sociais precisam fazer concessão a regimes expansivos de informação para se manterem adaptáveis, que no nível do foco compartilhado requer o manejo de disputa de visõesde-mundo. Os conceitos se formam a partir dessa competência combinatória de sentidos quase ilimitada do indivíduo (porém, com uma capacidade mais restrita de manter o foco na abstração destes sentidos) que se encontra com a capacidade do sistema social de distribuir abstrações (de diversas complexidades), mas com uma capacidade mais limitada de manejar contextos conflitantes. 


\section{CONCLUSÕES}

No percurso de uma pesquisa, é inevitável que objetivos e hipóteses se transformem, e com a presente pesquisa não foi diferente. Ao aprofundarmos nossas reflexões, uma abordagem baseada na noção de conflito entre paradigmas, notadamente entre a visão clássica (logicista) dos conceitos e a visão moderna, cognitiva e contextual, foi sendo substituída por uma abordagem integradora, que sopesasse o papel dessas duas visões sem, contudo, abandonar a atitude crítica. O viés crítico, que foi várias vezes retomado ao longo desta pesquisa sob diversos ângulos, voltou-se contra a noção de representação como memorizações cognitivas, seja sob a forma de esquemas reprodutores ou reconstituições (objetivas ou subjetivas) do meio. Acreditamos que esta noção é apenas uma forma de perenizar escolhas (individuais e/ou socialmente filtradas) através de um mecanismo de justificação: as boas representações refletem verdades essenciais (justificações transcendentais) $e$ boas representações refletem interpretações corretas (justificativas relativísticas). Essa abordagem deturpa o papel das representações, que é o de servirem como mediações entre indivíduo, sociedade e mundo, e que são erroneamente invocadas para justificar a existência de realidades ou verdades perenes, existam elas na mente ou no mundo. $\mathrm{O}$ fato das representações poderem ser remanejadas à vontade na linguagem sem perderem sua integridade não significa que provêm de uma fonte comum, apenas que existe uma deriva congruente entre os indivíduos que as manejam. As representações só existem enquanto objeto de mediação, como viabilizadoras de coordenações entre estados cognitivos não comensuráveis, e dialogicamente trazidas à mão; como diz Maturana, "tudo que é dito é dito por alguém".

Dar-se conta que as representações são sempre mediações, e não artefatos cognitivos que conduzem a comunicação é difícil, porém, ao se insistir em uma abordagem da informação como um fenômeno indeterminado, algo que pode ser tudo ou nada ao mesmo tempo. A abordagem diluidora da informação, como se esta fosse parte de um processo passivo de absorção de conteúdo ou estruturas mentais, reforça, pela fraqueza argumentativa, uma noção cognitivista de representação. Para superar esse obstáculo epistemológico, adotamos a abordagem sistêmica da informação, que compreende situar a informação como parte - e razão de ser - de um sistema. É uma 
abordagem ampla (no sentido que explica a informação em suas várias manifestações) e ao mesmo tempo dirigida (cada sistema só admite um modo de informação).

Em seu aspecto amplo, a informação é um diferencial surgido entre partes de um sistema que o obrigam a se reorganizar, produzindo assim um novo patamar organizacional. Em outras palavras, informação é uma diferença que obriga um sistema a produzir outra diferença. Em seu aspecto dirigido, o diferencial produzido é dependente das estruturas que o produzem. Seres vivos são sistemas estruturalmente espontâneos, portanto, podem tanto produzir quanto reproduzir diferenças, constituindo assim unidades que possuem os dois processos (ou seja, se autoproduzem). Máquinas, por outro lado, só podem reproduzir informações, portanto, só admitem diferenças mediante instrução. $\mathrm{O}$ que esses dois tipos de sistemas podem ter em comum são estruturas. Por exemplo, pode-se encontrar carbono, ferro e outros minerais tanto no computador quanto no corpo humano, o que os distingue é como estão organizados: o corpo humano está organizado através de processos autocatalíticos que o autoorganizam, o computador está organizado através de processos bi-estáveis que permitem que seja hétero-organizado (programado).

Existem, porém, os sistemas que parecem não compartilhar estruturas, mas cuja organização é uma "solução de continuidade" dos sistemas que os precedem. Por exemplo, programas de computador podem formar sistemas distintos que se diferenciam entre si por um princípio organizador derivado dos processos bi-estáveis programáveis: as "linguagens lógicas de programação". Por essa solução aberta (hétero-organizada), os computadores se comunicam trocando informações. A solução dada nos sistemas autopoiéticos (dos quais fazemos parte, como sistemas vivos), enfocados em nossa pesquisa, foi o fechamento operacional, e como consequência a necessidade contínua de produzir diferenças para superar a clausura operacional através da interação e estabelecer comunicação via coordenação do informar-se. Em outras palavras, é porque existe um excesso de distinções possíveis que selecionamos o que faz sentido, criando o sistema de consciência, e é porque existe um excesso de sentidos possíveis dispostos em coordenação através da interação que selecionamos o que comunicamos, criando sistemas sociais. Estes são sistemas, enfim, que se orientam pela diferença e não pela condução de um organizadum comum. Também salientamos que estes não são sistemas estruturados (não reproduzem uma estrutura), mas são estruturantes, no sentido de que criam condições que retroagem criando uma expansão da complexidade (cria-se uma 
escrita, que cria literatura, que fecunda ideias novas, que criam tecnologias que modificam os modos de escrita, e assim por diante). E são sistemas justamente por reproduzirem essas condições estruturantes, como possibilidades de sentido que se mantêm sempre no horizonte, mas não necessariamente selecionáveis. O princípio organizador dos sistemas de consciência, e por decorrência dos sociais, gira em torno dessa capacidade de seleção de sentido realizada através de mudanças da natureza do foco na distinção, ampliando-o ou concentrando-o. $\mathrm{O}$ foco da atenção concentrado produz estados de consciência mais abstratos e generalistas, embora reducionistas, e o desfocar produz estados mais amplos de atenção, combinando itens a contextos, mas sem deduzir causas e efeitos.

Conceitos começam pela formação de laços entre propriedades atribuídas a itens na memória ou no mundo e contextos (através de focos amplos); e o processo de formação conceitual continua quando esses laços são reconhecidos como episódios repetidos (através de foco concentrado), ganhando, assim, uma natureza abstrata. Quando o foco ganha uma maior dinâmica, conseguindo focar/desfocar com um maior grau de liberdade e precisão, o conceito ganha maior integridade ao poder ser evocado através de contextos diversos ao mesmo tempo em que pode ser abstraído deles como instâncias correlacionadas.

O conceito, balançando entre a abstração unitária e a ampliação contextual, está sempre no fio da navalha do processo de vir-a-ser, entre uma abstração infecunda (uma atribuição ground state) ou uma diluição contextual que não consegue ser evocada como uma instância mais geral e aplicável na comunicação. Como defendido nesta pesquisa, esse não é um processo que foi sempre igual, e mesmo atualmente pode estar em evolução. Se os hominídeos mais primitivos mal conseguiam sair de seus contextos imediatos, premidos pela sobrevivência, reconhece-se o homem atual justamente por conseguir se refugiar num mundo de imaginação, no qual os conceitos podem se multiplicar à vontade. Crucial para essa evolução foi a capacidade de compartilhar o foco com os outros, de fazer dos conceitos um objeto de coordenação mais ampla, em que o focar/desfocar se coloca sob regimes coordenativos. A própria capacidade de distinguir, portanto, de se informar, se vê colocada na situação de ter seu modo de qualificar a experiência sob um crivo de validação externo. Tomasello afirma que a cultura e seus frutos não são derivados dos processos cognitivos, mas que a cognição em geral é que é possibilitada pela cultura e pela linguagem. Para ele, a própria 
linguagem não se desenvolveria nas crianças se estas não passassem pelo que o autor chama de "cenas de atenção conjunta", processo em que crianças e adultos coordenam seu foco numa situação de aprendizado cultural (isto é, quando o adulto aponta para ligações entre conceitos que não fazem parte da cena imediata, unindo um conhecimento cultural a um aprendizado individual).

A conexão entre consciência e sistema social ocorre justamente quando a cognição confia o processo de focar/desfocar a uma coordenação coletiva para preencher sentidos que o mero foco individual não alcança. Deste modo, o processo de foco amplo e o processo de foco concentrado da consciência passam a participar de coordenações regulares que sistematizam estes dois processos, em que o foco cognitivo passa a se regular com sistemas sociais que privilegiam ora regimes expansivos de admissão de diferenças no informar/informar-se, ora regimes redutivos dessa admissão. E de modo retroativo, os sistemas sociais que se formam na configuração diferenciada desses regimes de informação precisam se ajustar ao foco cognitivo dos indivíduos, que essencialmente gira em torno das escalas informacional/temporal desse acoplamento. A escala da cognição humana é de trilhões de distinções por milissegundo (como afirmado por Tononi), mas de seleções de sentido limitadas ao curso de uma vida humana, enquanto a escala social é limitada pela interação entre oferta e seleção de sentido, que precisa sofrer reduções para que possa ser repetida na comunicação, mas que pode ser refinada ao longo de gerações.

Existiria, portanto, uma tendência dos sistemas sociais em direção a regimes redutivos de informação, de "estabilização" de sentidos, e dos sistemas cognitivos em direção a regimes expansivos, criativos. Mas não colocaríamos isso em termos de confronto. Conforme já argumentamos, são necessários os dois tipos de foco para se conseguir cultivar conceitos integrados, que é a base de qualquer cultura. Quando um observador foca a atenção nas particularidades lógicas de um conceito, ele está participando de um regime redutivo de informação, tanto participando de uma modelização da lógica típica a uma cultura ${ }^{113}$ quanto jogando cognitivamente com todas as distinções dedutivas que conseguir. Por outro lado, quando este observador procura desfocar das particularidades internas de um conceito procurando associações mais amplas e insuspeitas, também estará participando de regimes redutivos de informação

\footnotetext{
${ }^{113}$ Não negamos aqui a aplicabilidade universal da lógica, mas que esta muda, tanto no correr do tempo em certa cultura quanto de cultura para cultura, sendo mais apropriado falarmos de lógicas, no plural.
} 
quando tiver que passar para frente, na comunicação, uma nova associação como uma oferta de sentido. Isto acontece porque seleção e oferta de sentidos são reduções, premidas pela escala da interação entre psiquismo e sistema social, no ponto de contato entre esses dois sistemas. No ponto de foco máximo, para o sistema psíquico essa redução (seja como seleção ou oferta) é um significado (a observação de um sentido como "possuindo" unidade), e para o sistema social é uma bifurcação na comunicação na qual se diz sim ou não ao que foi comunicado (aqui só na oferta de sentido). Para o sistema psíquico a construção do significado é efêmera, enquanto para o sistema social ela chega a ser transgeracional e tão longeva quanto a interação comunicacional o permitir. Isto ocorre porque a atenção consciente é limitada, e ela reflui constantemente, não só por causas fortuitas (como cansaço e distrações), mas principalmente porque para cada foco que abstrai um sentido como uma unidade isolada segue-se um desfocar que recoloca essa seleção dentro de um emaranhamento de possibilidades de sentido (estado esse que é a condição primeira para que ocorra a seleção de sentido). Por outro lado, um sistema social é constituído a partir de uma série de focos de atenção, daquilo que foi considerado pertinente continuar ou não como oferta de sentido, portanto, um sistema social se organiza em torno de definições e redefinições. Porém, porque não pode realizar seleções (já que não constitui uma unidade orgânica) organiza-se como modelos de seleções de sentido possíveis. Esses modelos, em sua abrangência e complexidade, dependem de como a interação na comunicação favorece este ou aquele tipo de foco.

Esse favorecimento sofre uma gradação a partir de uma interação mais restrita, mediada por instrumentos mais abstratos (por exemplo, a fixação de um significado no dicionário) que se organiza através do foco em definições, até uma interação mais aberta, mediada pelas representações do sentido a ser dicionarizado. Geralmente, este exemplo é explicado como a diferença entre algo que foi fixado (o significado) e algo em construção (o sentido), que pode vir a se transformar em algo fixo (um significado em um dicionário ou num vocabulário). Nossa abordagem acrescenta a esta abordagem mais geral um mecanismo que a explique enquanto fenômeno informacional: o foco do observador. O mecanismo específico dessa diferença entre significado e sentido está no modo como o foco do observador mantém a atenção sobre um item (objeto ou fenômeno). Esse modo é dividido na alternância entre isolar/deslocar o item de um contexto (em suma, abstraí-lo) e em combiná-lo com outros contextos até integrá-lo 
numa experiência (torná-lo contextualmente pleno de sentido). Portanto, o item não está a priori no dicionário (como significado) ou nas mediações da representação (como sentido). Ou seja, não deveríamos pensar numa transferência - em definitivo - do sentido para o significado. É o foco do observador que, na interação, constrói essa relação. O que também significa que as representações não são intrinsecamente objetivas ou subjetivas, mas construídas através de uma relação mais abstrativa ou mais contextual. Quanto mais contextual a relação menos conseguimos separar o item da experiência de sentido, assim se afastando de uma relação contextual reduzida em que o item passaria a ser objeto de definições. Por exemplo, como na cerimônia do chá citada anteriormente. Se o foco do observador está imerso na experiência de sentido, ele não isola os diversos itens à sua volta (as vestimentas, as xícaras, os instrumentos de preparo, etc.) dos diversos contextos entrelaçados que dão sentido a esses itens (as posturas, a reverência, as diferenças de status social de cada participante, a arquitetura do espaço); entrelaçamento contextual este que modela a cada passo as seleções de sentido a perfazer. Nesse regime, o foco reduz ao mínimo as seleções abstrativas, focando mais a cena contextual com um todo (foco amplo). Se o observador fosse um sociólogo exercendo o trabalho de compor um quadro social dessa cena provavelmente isolaria os itens em relação a um contexto de função entre estratos sociais, retirando daí as definições de cada item observado.

Deste modo, a diferença entre informação e sentido é também sistêmica, organizada através do continuum cognitivo de forma pendular; numa ponta o foco máximo (o significado em sua expressão mais precisa) e na outra ponta uma consciência desfocada na qual as distinções - a informação - estão num estado de superposição (ou seja, de interconexão máxima, portanto, num potencial de múltiplos sentidos). Enquanto num extremo desse continuum cognitivo a construção da realidade é efêmera em seu contato com o sistema social (como significados), no outro extremo o sentido é abrangente e persistente na qualificação da experiência (em todos os níveis), mas está encerrado em qualia não comunicáveis. Arriscamos-nos a dizer que a mediação do sentido se situa numa zona cinzenta entre esses dois extremos, em que um foco de transição entre o amplo e o restrito permite a instauração de regimes expansivos de informação, nos quais a distinção coordena valores e conceitos elaborados coletivamente, mas que, por serem difusamente instanciados, necessitam de uma atualização regular (focar uma significação). Por esse motivo, a nossa abordagem 
também é importante por especificar que nem tudo que está em construção é sentido, fazendo a ressalva, então, que regimes redutivos também podem ser instanciados coletivamente, como no caso da aceitação de categorias. Por exemplo, definir o ser humano como um "ser racional" é uma categorização comum, diversas vezes retomada desde Aristóteles, mas que reduz o sentido de "ser humano" a um só contexto, o "racional".

Estimamos que existam muitas gradações conceituais, desde as mais abstratas, como as categorias de cunho aristotélico, passando por categorizações mais complexas e contextuais (mas ainda assim mediadas sob regimes redutivos), até grandes composições integradas de conceitos formando visões-de-mundo. Afirmamos que nem toda mediação é de sentido, que esta só ocorre mais próxima da construção da experiência de sentido, na qual os conceitos, por serem multi-contextuais, são participantes dessa construção. Também seria necessário esclarecer que nessa zona de construção do sentido a mediação não pode ser entendida como uma negociação, como se fosse possível chegar a um denominador comum ou a um sentido homogeneamente distribuído entre os indivíduos. Nesse nível interacional mediação significa uma abertura para o diferente e o divergente, que quando selecionado como sentido acrescenta um enriquecimento ao vínculo criado com os outros através dos conceitos compartilhados na comunicação. Ou seja, compartilhamos conceitos com os outros, mas o sentido em torno destes é sempre orientado pela diferença, a qual é modelada pela capacidade do observador mudar o contexto, ou de fundir contextos em novos níveis. Nessa zona de mediação do sentido, conceitos se transmutam em contextos, e por sua vez contextos se transmutam em conceitos, formando uma verdadeira rede ecológica de co-dependências contextuais, como o defendem Gabora, Rosch e Aerts (2008).

A solução integrativa que defendemos para o problema da conciliação entre a abordagem clássica (baseada na lógica e na segmentação) e a abordagem contemporânea (baseada na contextualidade e na exemplaridade) dos conceitos se baseia no entendimento dessa dinâmica de codependência. No lugar da solução tradicional (um núcleo de coerências perceptivas seguido de um processo identificatório), propomos uma abordagem sistêmica na qual os dois aspectos são apenas uma divisão de um processo complexo e abrangente, que envolve a emergência dos sistemas psíquicos e sociais e a coevolução destes através do processo da formação e comunicação dos conceitos. Essa abordagem sistêmica foi delineada nesta pesquisa 
em âmbito paradigmático e correlacionada à questão da formação dos conceitos para oferecer uma visão alternativa aos impasses teóricos levantados pelas pesquisas em Ciência da Informação sobre a formação dos conceitos. Quanto aos objetivos desta pesquisa, acreditamos que demonstramos a pertinência da abordagem sistêmica da informação para colocar o fenômeno da informação como central ao entendimento da natureza dos conceitos. Também acreditamos ter confirmado a hipótese desta pesquisa: a de que em Ciência da Informação não existem abordagens da formação dos conceitos baseadas na compreensão do fenômeno informacional e de que, por esta razão, as teorias voltadas para entender a natureza do conceito geralmente pendem a tomar como paradigma o dualismo objetivo-subjetivo como explicativo da formação das representações. Concluímos que a Ciência da Informação, por ter como objeto de estudo a própria informação, necessita se aproximar do estudo dos conceitos não só da perspectiva da recuperação da informação (ou seja, dos conceitos como unidades significativas), mas também incorporar a perspectiva mais ampla da formação dos conceitos desde as zonas de mediação do sentido, refletindo sobre como os sistemas de informação (geralmente construções verticais da comunicação) podem se flexibilizar para realizar esta incorporação.

Pela própria abrangência da proposta, algumas questões que ficaram em aberto, como o delineamento de uma teoria do conceito baseada na abordagem sistêmica, assim como o cotejamento dessa abordagem com a teoria ecológica dos conceitos de Rosch, Gabora e Aerts (cujos aspectos mais formais foram apenas arranhados nesta pesquisa). Que essas questões, da mesma maneira que outras que venham a instigar os futuros leitores desta pesquisa, possam ganhar um rumo e prosperar. 


\section{BIBLIOGRAFIA}

\section{AMERICAN NATIONAL STANDARD / NATIONAL INFORMATION}

STANDARDS ORGANIZATION. Z39.19: guidelines for the construction, format, and management of monolingual controlled vocabularies. Bethesda: NISO Press, 2005.

ARANDALE, Michael Maya. Reflexões sobre os sistemas categoriais de Aristóteles,Kant e Ranganathan. Ciência da Informação, Brasília, v. 38, n. 1, p. 86-108, jan./abr. 2009.

ARAUJO, Carlos Alberto Ávila. Correntes teóricas da ciência da informação. Ciência da Informação, Brasília, v. 38, n. 3, dez. 2009 . Disponível em:

$<$ http://www.scielo.br/scielo.php?script=sci_arttext\&pid=S0100-

19652009000300013\&lng=en\&nrm=iso>. Acesso em: 09 maio 2013.

ATLAN, H. A organização biológica e a teoria da informação. Lisboa: Instituto Piaget, 2008.

AZEVEDO NETTO, C. X. A abordagem do conceito como uma estrutura semiótica. TransInformação, Campinas, v. 20, n. 1, p. 47-58, jan./abr. 2008.

AZEVEDO NETTO, C. X. Signo, sinal, informação: as relações de construção e transferência de significado. Informação \& Sociedade: estudos, v. 12, n. 2, 2002.

BACHUR, J. P. Distanciamento e crítica: limites e possibilidades da teoria de sistemas de Niklas Luhmann. 2009. 356 p. Tese (Doutorado em Ciência Política) - Faculdade de Filosofia, Letras e Ciências Humanas da Universidade de São Paulo, 2009.

BARITÉ, Mario. Diccionario de organización y representación del conocimiento: clasificación, indización, terminologia. Uruguai: s.e., 2000. Disponível em: <http://http://164.73.14.9/kod/espaniol/diccionario.php>. Acesso em: 10 mar.2013.

BARRETO, A. A. A estrutura do texto e a transferência da informação.

DataGramaZero: Revista de Ciência da Informação, v. 6, n. 3, jun. 2005. Disponível em: 〈http://www.aldoibct.bighost.com.br/A\%20estruturadoTexto.pdf >. Acesso em: 03 jun. 2012.

BERTALANFFY, L. von. Teoria geral dos sistemas. Petrópolis: Vozes, 1973.

BORODITSKY, L. Como a linguagem modela o pensamento. Scientific American Brasil, ano 9, n. 106, p. 61-63, mar. 2011.

BUCKLAND, M.K. Information as thing. Journal of the American Society for Information Science (JASIS), v. 45, n. 5, p. 351-360, 1991.

BUFREM, L. S.; GABRIEL JUNIOR, R. F. A apropriação do conceito como objeto na literature periódica científica em Ciência da Informação. Informação Informação, Londrina, v. 16, n. 3, p. 52-91, jan./jun. 2011. 
CAMPOS, L. F. B.; VENÂNCIO, L. S. Perspectivas em (in)formação: tendências e tensões entre abordagens físicas, cognitivistas e emergentes. TransInformação, Campinas, v.19 n.2, p.107-118, maio/ago. 2007

CAPRA, F. A teia da vida: uma nova compreensão dos sistemas vivos. São Paulo: Cultrix, c1996.

CAPURRO, R. Pasado, presente y futuro de la noción de información. Apresentado no 1. Encuentro Internacional de Expertos en Teorías de la Información: un enfoque interdisciplinar, 2008. Disponível em: 〈http://www.capurro.de/leon.pdf>. Acesso em: 20 maio 2010.

CAPURRO, R.; HJORLAND, B. O conceito de informação. Perspectivas em Ciência da Informação, v. 12, n. 1, 2007. Disponível em: <http://www.eci.ufmg.br/pcionline/>. Acesso em: 06 out. 2009.

CAPURRO, R. Epistemologia e Ciência da Informação. Palestra apresentada no V Encontro Nacional de Pesquisa em Ciência da Informação, Belo Horizonte (Brasil), 2003. Disponível em:

<http://www.capurro.de/enancib_p.htm>. Acesso em: 03 maio 2010.

COHN, G. As diferenças finais: de Simmel a Luhmann. Revista Brasileira de Ciências Sociais, São Paulo, v. 13, n. 38, out. 1998. Disponível em:

$<$ http://www.scielo.br/scielo.php?script=sci_arttext\&pid=S0102-

69091998000300003\&lng=en\&nrm=iso>. Acesso em: 26 nov. 2011.

DAHLBERG, Ingetraut. A referent-oriented, analytical concept theory of Interconcept. International Classification, v. 5, n. 3, p. 122-151, 1978a.

DAHLBERG, I. Fundamentos teórico-conceituais da classificação. Revista de Biblioteconomia de Brasília, Brasília, v. 6, n. 1, p. 9-21, jan./ jun. 1978 b.

DAHLBERG, I. Teoria do conceito. Ciência da Informação, v. 7, n. 2, p. 101-107, 1978c.

DAHLBERG, I. Teoria da classificação, ontem e hoje. In: CONFERÊNCIA BRASILEIRA DE CLASSIFICAÇÃO BIBLIOGRÁFICA, 1, 12-17 set. 1972, Rio de Janeiro.Anais. Brasília: IBIBT/ ABDF, 1979, p. 352-370. Palestra. Disponível em: $<$ http://www.conexaorio.com/biti/dahlbergteoria/dahlberg_teoria.htm\#S1 >. Acesso em: 10 fev. 2008.

DAHLBERG, I. Knowledge organization and terminology: philosophical and linguistic bases. International Classification, v. 19, n. 2, p. 65-71, 1992.

DAHLBERG, I. Knowledge organization: a new science? Knowledge Organization, v. 33, n. 1, p. 11-19, 2006.

DAMÁSIO, A. R. E o cérebro criou o homem. São Paulo: Companhia das Letras, 2011.

DA SILVA, J. J. Informação e auto-organização. In: Debrun, M.; Gonzales, M. E. Q.;

Pessoa Jr., O. (Org.). Auto-organização: estudos interdisciplinares em filosofia, ciências 
naturais e humanas, e artes. Campinas: UNICAMP, Centro de Lógica, Epistemologia e História da Ciência, 1996, p.103-128.

DERQUI, P. M. O paradigma biológico do conhecer e a questão da informação. DataGramaZero: Revista de Ciência da Informação, v. 6, n. 6, dez. 2005. Disponível em: <http://www.dgz.org.br/dez05/Art_05.htm>. Acesso em: 06 out. 2009.

DERQUI, P. M. Fundamentos dos conceitos de informação e conhecimento em Ciência da Informação através de uma abordagem dos paradigmas emergentes da autoorganização e da autopoiese. 2004. 144 f. Dissertação (Mestrado em Ciências da Informação) - Escola de Comunicações e Artes, Universidade de São Paulo, São Paulo, 2004.

DERQUI, P. M.. Mediação e recepção da informação sob a ótica de Niklas Luhmann. In : Anais da $2^{a}$. Jornada Científica Internacional da Rede Mussi: redes e processos info-comunicacionais: mediações, memórias, apropriações (2. : 24-26 out. 2012 : Rio de Janeiro, RJ). Rio de Janeiro: Fiocruz, 2012. p. 412-425.

ECO, U. Kant e o ornitorrinco. Rio de Janeiro: Record, 1998.

ESTEVES DE VASCONCELLOS, M. J. Pensamento sistêmico: o novo paradigma da ciência. Campinas: Papirus, 2010.

FRANCELIN, M. M. A ordem dos conceitos na organização da informação e do conhecimento. 2010. 220 f. Tese (Doutorado em Ciências da Informação) - Escola de Comunicações e Artes, Universidade de São Paulo, São Paulo, 2010.

FOLEY, R. A.; MIRAZÓN LAHR, M. The evolution of diversity of cultures. Philosophical Transactions of the Royal Society B: biologial sciences, n. 366, p.1080198, mar. 2011.

FRAGASZY, D.; PERRY, S. Towards a biology of traditions. In: (Ed.). The biology of traditions: models and evidence. Cambridge: Cambridge University Press, 2003. p. 1-50.

GERSHENSON, C. A general methodology for designing self-organizing systems. In: CORNELL UNIVERSITY LIBRARY. arXiv. Disponível em: <http://arxiv.org/abs/nlin/0505009>. Acesso em: 06 out. 2009. Artigo de 2006.

GABORA, L.; AERTS, D. A model of the emergence and evolution of integrated worldviews. Journal of Mathematical Psychology, 53, p. 434-451, 2009. Depósito eletrônico: arXiv:1001.1399v1 [q-bio.NC] 9 Jan 2010. Disponível em: <http://arxiv.org/pdf/1001.1399v1.pdf>. Acesso em: 05 jun. 2014.

GABORA, L.; ROSCH, E.; AERTS, D. Toward an ecological theory of concepts. Ecological Psychology, n. 20, p. 84-116, 2008.

GLEICK, J. A informação: uma história, uma teoria, uma enxurrada. São Paulo: Companhia das Letras, 2013.

GONZÁLEZ DE GOMEZ, M. N. As ciências sociais e as questões da informação. Morpheus - Revista Eletrônica em Ciências Humanas, ano 09, n. 14, 2012. 
GONZÁLEZ DE GOMEZ, M. N.; CHICANEL, M. A mudança de regimes de informação e as variações tecnológicas. In: IX ENANCIB. Anais. São Paulo, 2008.

GONZÁLEZ DE GOMEZ, M. N. Novas fronteiras tecnológicas das ações de informação: questões e abordagens. Ciência da Informação, Brasília, v. 33, n. 1, p. 5567, jan./abril 2004.

HEYLIGHEN, F.; JOSLIN, C. Cybernetics and Second-Order Cybernetics. In: MEYERS, R..A. (Ed.). Encyclopedia of physical science \& technology. 3.ed. New York: Academic Press, 2001. Disponível em:

<http://www.sciencedirect.com/science/referenceworks/9780122274107\#ancpt0030>. Acesso em: 03 jun. 2012.

INTERNATION STANDARDS ORGANIZATION. 25964-1: information and documentation: thesauri and interoperability with other vocabularies - Part 1: thesauri for information retrieval. AENOR: Madrid, 2011.

JABR, F. Por que o cérebro prefere o papel. Scientific American Brasil, n. 193, dez. 2013.

KNOWLEDGE map of information science: Rafael Capurro's responses to Chain Zins (2007). Disponível em: <http://www.capurro.de/zins.html>. Acesso em: 03 maio 2010.

KOBASHI, N. Y.; FRANCELIN, M. M. Conceitos, categorias e organização do conhecimento. Informação Informação, Londrina, v.16, n. esp., p. 1-24, jan./jun. 2011.

KOBASHI, N. Y.; TÁLAMO, M.F.G.M. Informação: fenômeno e objeto de estudo da sociedade contemporânea. Transinformação, Campinas, n. 15 (edição especial), p. 7-21, set./dez., 2003.

KUHN, T. S. A estrutura das revoluções científicas. 6.ed. São Paulo: Perspectiva, 2001.

LARA, M. L. G. Documento e significação na trajetória epistemológica da Ciência da Informação. In: MARCODES, C. H.; RODRIGUES, A. C. (Org.). Documento: gênese e contextos de uso. Niterói: EdUFF, 2010, p. 35-56.

LARA, M. L. G. Informação, informatividade e Lingüística Documentária: alguns paralelos com as reflexões de Hjorland e Capurro. DataGramaZero: revista de Ciência da Informação, v. 9, n. 6, dez. 2008. Disponível em:

<http://www.dgz.org.br/dez08/Art_01.htm>. Acesso em: 03 jun. 2012.

LARA, M. L. G. O processo de construção da informação documentária e o processo de conhecimento. Perspectivas em Ciência da Informação, Belo Horizonte, v. 7, n. 2, p.127-139, jul./dez. 2002.

LIANG, Thow-Yick. General information theory: some macroscopic dynamics of the human thinking systems. Information Processing and Management, v. 34, n. 2/3, p. 275-290, mar./may 1998. 
LIMA, G. A. B. O. As categorias e a categorização contemporânea: enfoque sobre os olhares da biblioteconomia e ciência da informação e das ciências cognitivas. Revista Interamericana de Biblioteconomia Medellín (Colombia), v. 34, n. 3, 2011.

LIMA, G. A. B. Categorização como um processo cognitivo. Ciências \& Cognição, v.11, p. 156-167, 2007.

LIMA, G. A. B. Interfaces entre a ciência da informação e a ciência cognitiva. Ciência da Informação, Brasília, v. 32, n. 1, p. 77-87, jan./abr. 2003.

LIMA, G. A. B. O. Modelos de categorização: apresentando o modelo clássico e o modelo de protótipos. Perspectivas em Ciência da Informação, v. 15, n. 2, p. 108-122, maio/ago. 2010.

LOGAN, R. K. Que é informação? : a propagação da organização na biosfera, simbolosfera, na tecnologia e na econosfera. Rio de Janeiro: Contraponto; PUC-Rio, 2012.

LUHMANN, N. A realidade dos meios de comunicação. 2.ed. São Paulo: Paulus, 2011.

LUHMANN, N. Introdução à teoria dos sistemas. Petrópolis: Vozes, 2009.

LUHMANN, N. Sociedad y sistema: la ambición de la teoria. Barcelona: Paidós, 1990.

MAGNANI, M. C.B; PINHEIRO, M. M. K. "Regime" e "Informação": a aproximação de dois conceitos e suas aplicações na Ciência da Informação. Liinc em Revista, v. 7, n. 2, p. 593-610, 2011.

MAGRO, C. Representação, virtus dormitiva e linguagem. In: OLIVEIRA, P.; BENNIBLER, V.; MENDES, E. (Org.) Revisitações: Edição Comemorativa dos 30 anos da Faculdade de Letras. Belo Horizonte: Editora FALE/UFMG. 1999. p. 29-44.

MARRADI, A. The concept of concept: concepts and terms. Knowledge Organization, v. 39, n. 1, p. 29-54, 2012.

MATHEUS, R. F. Rafael Capurro e a filosofia da informação: abordagens, conceitos e metodologias de pesquisa para a Ciência da Informação. Perspectivas em Ciência da Informação, v. 10, n. 2, p. 140-165, 2005.

MATURANA ROMESÍN, H. Cognição, ciência e vida cotidiana. Belo Horizonte: Editora UFMG, 2001.

MATURANA ROMESÍN, H. A ontologia da realidade. Belo Horizonte: Editora UFMG, 1999.

MATURANA ROMESÍN, H.; VARELA GARCÍA, F. J. A árvore do conhecimento: as bases biológicas da compreensão humana. São Paulo: Palas Athena, 2002.

MATURANA ROMESÍN, H.; VARELA GARCÍA, F. J. De máquinas y seres vivos: autopoiesis, la organización de lo vivo. 6.ed. Buenos Aires: Editorial Universitária; Lumen, 2004. 
MEDIN, D. L., S MITH , E. E. Concepts and concept formation. Annual Review of Psychology, Palo Alto, v. 35, p. 113-138, 1984.

MERVIS, C. B; CATLIN, J.; ROSCH, E. Development of the estructure of color categories. Developtnemal Psychology, v. 2, n. 1, p. 54-60, 1975.

MORIN, Edgar. Introdução ao pensamento complexo. 3.ed. Porto Alegre: Sulina, 2007.

MULLER, H. R.; PRADO, K. B. Epigenética: um novo campo da genética. Revista UnicenP de Biologia e Saúde, Curitiba, v. 1, n. 3, p. 61-69, set./dez. 2008. Disponível em: 〈http://www.slideshare.net/ThuaneSales/epigentica-um-novo-campo-da-gentica>. Acesso: 17 jun. 2013.

NICOLELIS, M. Muito além do nosso eu: a nova neurociência que une cérebro e máquinas e como ela pode mudar nossas vidas. São Paulo: Companhia da Letras, 2011.

OLIVEIRA, M. B. Conceitos e estrutura mental. Trans/Form/Ação, São Paulo, v. 14, p. 73-91, 1991. Disponível em:

<http://www.scielo.br/scielo.php?script=sci_arttext\&pid=S0101-

31731991000100004\&lng=en\&nrm=iso>. Acesso em: 30 maio 2012.

OLIVEIRA, M. B.; OLIVEIRA, M. K. Investigações cognitivas: conceitos, linguagem e cultura. Porto Alegre: Artes Médicas, 1999.

OSBERSON, D. N.; SMITH, E. E. On the adequacy of prototype theory as a theory of concepts. Cognition, v. 9, p. 35-58, 1981.

OTTA, E.; RIBEIRO, F. L.; BUSSAB, V. S. R. Inato versus adquirido: a persistência da dicotomia. Revista de Ciências Humanas, Florianópolis: EDUFSC, n. 34, p. 283-311, out. 2003.

PRIGOGINE, I.; STENGERS, I. Entre o tempo e a eternidade. São Paulo: Companhia das Letras, 1992.

RAICHLE, M. E. A energia escura do cérebro. Scientific American Brasil, n. 95, abril 2010.

RAICHLE, M. E. A paradigm shift in functional brain imaging. The Journal of Neuroscience, v. 29, n. 41, Oct. 2009. Disponível em:

<http://www.jneurosci.org/content/29/41/12729>. Acesso em: 09 jun. 2013.

RESENDE, C. V.; FERNANDES JÚNIOR, R. Código e informação. São Paulo: Atual, 1988.

RORTY, R. A filosofia e o espelho da natureza. Lisboa: Dom Quixote, 1988.

ROSCH, E. Cognitive representations of semantic categories. Journal of Experimental Psychology: general, v. 104, p. 192-233, 1975a.

ROSCH, E. The nature of mental codes for color categories. Journal of Experimental Psychology: human perception and performance, v. 1, n. 4, p. 303-322, 1975 b. 
ROSCH, E.; HEIDER. Probabilities, sampling, and ethnographic method: the case of dani colour names. Man, New Series, v. 7, n. 3, p. 448-466, Sept. 1972. Disponível em: < http://www.jstor.org/stable/2800917>. Acesso em: 28 mar. 2013.

ROSCH, E.; SIMPSON, C.; MILLER, R. S. Structural bases of typicality effects. Journal of Experimental Psychology: human perception and performance, v. 2, n. 4, 491-502, 1976.

RUSSELL, B. Human knowledge: its scope and limits. London: George Allen \& Unwin, 1948.

SANTOS, B. S. Um discurso sobre as ciências. 2.ed. Porto: Afrontamento, 1988.

SHANNON, C. E.; WEAVER, W. A teoria matemática da comunicação. São Paulo; Rio de Janeiro: DIFEL, 1975.

SEJNOWSKI, T.; DELBRUCK, T. A linguagem do cérebro. Scientific American Brasil, n. 126, nov. 2012.

SNOWDON, C. T. From primate communication to human language. In: WAAL, F. B. M. (Ed.). Tree of origin: what primate behavior can tell us about human social evolution. Cambridge: Harvard University Press, 2001. p. 193-227.

TOMASELLO, M. Origens culturais da aquisição do conhecimento humano. São Paulo: Martins Fontes, 2003.

TONONI, Giulio. Consciousness as integrated information: a provisional manifesto. Biological Bulletin, v. 215, n. 3, p. 216-242, dez. 2008.

UEXKÜLL, T. Von. A teoria da Umwelt de Jakob Von Uexküll. Galáxia: Revista Transdiciplinar de Comunicação, Semiótica e Cultura, n. 7, p. 19-48, abril 2004.

VARELA GARCÍA, F. J.; THOMPSON, E.; ROSCH, E. A mente incorporada: ciências cognitivas e experiência humana. Porto Alegre: Artmed, 2003.

VÊNANCIO, L. S.; BORGES, M. E. N. Cognição situada: fundamentos e relações com a Ciência da Informação. Encontros Bibli: Revista Eletrônica de Biblioteconomia e Ciência da Informação, Florianópolis, n. 22, $2^{\circ}$ sem. 2006. Disponível em : http://www.redalyc.org/articulo.oa?id=14702204. Acesso em : 05 jun. 2014.

VÊNANCIO, L. S.; BORGES, M. E. N. O comportamento de busca de informação sob o enfoque da cognição situada: um estudo empírico qualitativo. Ciência da Informação, Brasília, v. 37, n. 1, p. 95-106, jan./abr. 2008.

WIENER, N. Cibernética e sociedade: o uso humano de seres humanos. São Paulo: Cultrix, 1978.

ZEMAN, J. Significado filosófico da noção de informação. In: ROYAUMONT, C. (Ed). O conceito de informação na ciência contemporânea: colóquios filosóficos internacionais de Royaumont. Rio de Janeiro: Paz e Terra, 1970. p.154-179. 
ANEXO

\section{CORPUS BIBLIOGRÁFICO}




\section{CORPUS BIBLIOGRÁFICO}

ALLEN, B. L. Cognitive research in information science: implications for design. Annual Review of Information Science and Technology, v. 26, p. 3-37, 1991.

ANDERSEN, J. Communication technologies and the concept of knowledge organization - a medium-theory perspective. Knowledge Organization, v. 29, n. 1, p. 2939, 2002.

ANJOS, L. Sistemas de classificação do conhecimento na filosofia e na biblioteconomia: uma visão histórico-conceitual crítica com enfoque nos conceitos de classe, de categoria e de faceta. 2008. 290 p. Tese (Doutorado). - Escola de Comunicações e Artes, Universidade de São Paulo, São Paulo, 2008.

ANDERSEN, J. and SKOUVIG, L. Knowledge organization: a sociohistorical analysis and critique. Library Quarterly, v. 76, n. 3, p. 300-322, 2006.

ARANDALE, Michael Maya. Reflexões sobre os sistemas categoriais de Aristóteles,Kant e Ranganathan. Ciência da Informação, Brasília, v. 38, n. 1, p. 86-108, jan./abr. 2009

ARTÊNCIO, L. M. Princípios de categorização nas linguagens documentárias. 2007. 129 p. Dissertação (Mestrado em Ciências da Informação) - Escola de Comunicações e Artes, Universidade de São Paulo, São Paulo, 2007.

BARAT, A.H. Human perception and knowledge organization: visual imagery. Library Hi Tech, United Kingdom, v. 25, n. 3, p. 338-351, 2007.

BARITE, M. G. The notion of 'category': its implications in subject analysis and in the construction and evaluation of indexing languages. Knowledge Organization, v. 27, n. $1 / 2$, p. 4-10, 2000

DAHLBERG, I. Brief Communication: How to improve ISKO's standing. Ten desiderata for knowledge organization. Knowledge Organization, v. 38, n. 1, p. 69-74, 2011.

DAHLBERG, Ingetraut. Teoria do conceito. Ciência da Informação, v. 7, n. 2, p. 101107, 1978.

DING, Y. and FOO, S. Ontology research and development. Part 1: a review of ontology generation. Journal of Information Science, v. 28, n. 2, p. 123-136, 2002.

GODERT, W. Information as a cognitive construction: a communication theoretic model and consequences for information systems. Knowledge Organization, v. 23, n. 4, p. 206-12, 1996.

FRIEDMAN, A. and THELLEFSEN, M. Concept theory and semiotics in knowledge organization. Journal of Documentation, United Kingdom, v. 67, n. 4, p. 644-674, 2011. 
HJORLAND, B. What is Knowledge Organization (KO)? Knowledge Organization, v. 35, n. 2-3, p. 86-101, 2008.

HJORLAND, B. Fundamentals of knowledge organization. Knowledge Organization, v. 30, n. 2, p. 87-111, 2003.

JAENECKE, P. To what end knowledge organization. Knowledge Organization, v. 21, n. 1, p. 3-11, 1994.

KOBAIASHI, N.Y.; FRANCELIN, M.M. Conceitos, categorias e organização do conhecimento. Informação Informação, Londrina, v. 16, n. esp, p. 1-24, jan./jun. 2011.

KUZNETSOV, V. On triplet classifications of concepts. Knowledge Organization, v. 24, n. 3, p. 163-75, 1997.

Lima, Gercina Ângela Borém de Oliveira. Modelos de categorização: apresentando o modelo clássico e o modelo de protótipos. Perspectivas em Ciência da Informação, v.15, n. 2, p. 108-122, maio./ago. 2010.

MARRADI, A. The concept of concept: concepts and terms. Knowledge Organization, v. 39, n.1, p. 29-54, 2012.

PIEDADE, M. A. R. Introdução à teoria da classificação. Rio de Janeiro: Interciência, 1983.

STOCK, W.G. Concepts and semantic relations in Information Science. Journal of the American Society for Information Science and Technology, United States, v. 61, n. 10, p. 1951-1969, 2010.

STOCK, W.G. Concepts and semantic relations in Knowledge Representation. Information, Germany, v. 60, n. 8, p. 403-420, 2010.

THELLEFSEN, T.L.; THELLEFSEN, M.M. Pragmatic semiotics and knowledge organization. Knowledge Organization, v. 31, n. 3, p. 177-187, 2004.

ZHIJIN, W. From information organization to knowledge organization. Journal of the China Society for Scientific and Technical Information, v. 17, n. 3, p. 230-234, 1998.

ZINS, Chaim. Knowledge organization: an epistemological perspective. Knowledge Organization, v. 31, n. 1, p. 49-63, 2004. 